Aquatic Community Classification and Ecosystem Diversity in Montana's Missouri River Watershed

Prepared for:

Bureau of Land Management

By:

David M. Stagliano

Montana Natural Heritage Program

Natural Resource Information System

Montana State Library

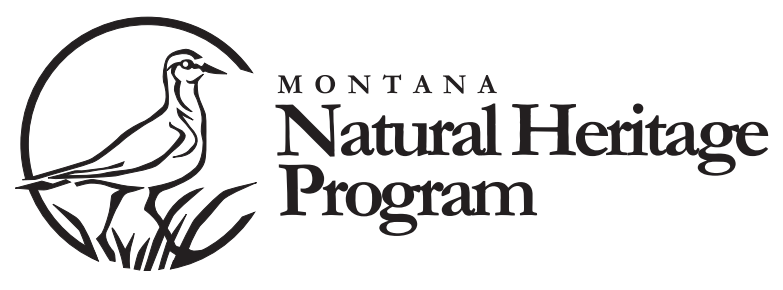





\section{Aquatic Community Classification and Ecosystem Diversity in Montana's Missouri River Watershed}

Prepared for:

Bureau of Land Management

Agreement Number:

ESA 010009 TO \#20

By:

David M. Stagliano
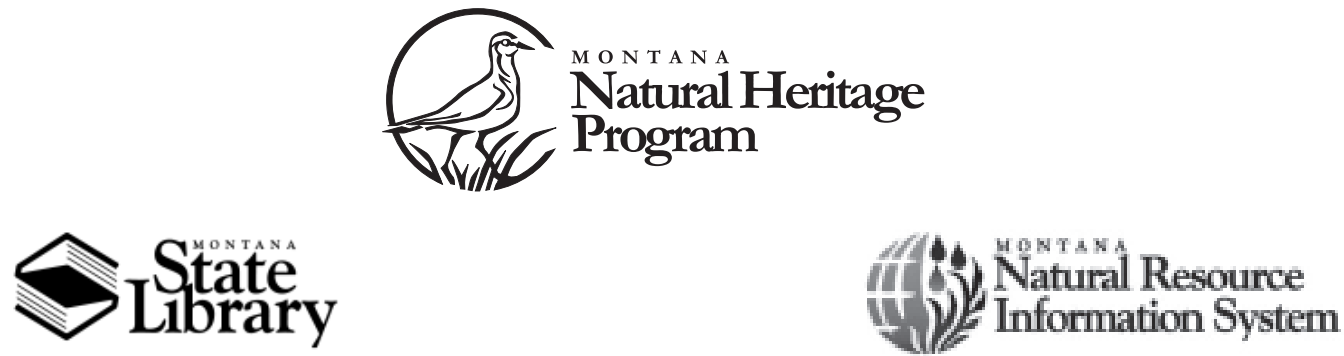

(C) 2005 Montana Natural Heritage Program

P.O. Box $201800 \bullet 1515$ East Sixth Avenue • Helena, MT 59620-1800 • 406-444-5354 
This document should be cited as follows:

Stagliano, David, M. 2005. Aquatic Community Classification and Ecosystem Diversity in Montana's Missouri River Watershed. Report to the Bureau of Land Management. Montana Natural Heritage Program, Helena, Montana. 65 pp. plus appendices. 


\section{Executive Summary}

The aquatic ecosystems of Montana's lowerelevation and prairie streams have not been well documented, yet these streams support some of the most intact native fish and invertebrate communities in the state. Only recently have there been efforts to sample and describe the interactions among the state's eastern aquatic biota, and relating prairie stream aquatic communities to their landscapes. However, Montana has lacked a system for defining and classifying aquatic communities.

In response to this need, the Montana Natural Heritage Program began an Aquatic Community Classification Project in 2003, with support from the Bureau of Land Management and The Nature Conservancy, to sample, identify and characterize stream communities within the Upper Missouri River Zoogeographic Region of Montana. This study evaluates the components and patterns of lotic ecosystems across all ecoregions of the upper Missouri River basin. We used cluster analysis and nonmetric multidimensional scaling (NMS) to classify biological communities of fish and macroinvertebrate assemblages and then related those groups to aquatic ecological units based on abiotic habitat variables, creating a classification system that predicts aquatic community occurrences within watersheds. Indicator species analysis (ISA) was performed on the community groups to determine the characteristic taxa of specific communities. The results of this work provide a better foundation for understanding and documenting the diversity of aquatic systems in Montana's Missouri River watershed.

To create a community database for analysis, over 100,000 data records were compiled from a number of sources covering over 1150 stream sites, from the smallest mountain stream to the mainstem Missouri River. Data coverage was evaluated, and we spent two field seasons collecting biological data on macroinvertebrate and fish assemblages in six watersheds to fill data gaps for particular stream systems. Geographic data describing key watershed parameters such as land cover, stream gradient and underlying geology was assembled in a Geographic Information System (GIS).

We developed a hierarchical classification framework defining 38 Aquatic Ecological System (AES) types, 178 macrohabitat types and identified the five dominant variables structuring the stream and river communities within the ecoregions. Distribution maps based on physical parameters of stream ecosystem types and macrohabitats in the watershed were produced for five pilot watersheds.

Macroinvertebrate communities: Genus/ species level taxonomic data from 289 sites with 444 taxa was analyzed and produced 12 distinct community groups. These community groups were related to elevation, geomorphology, stream size, current velocity and their tolerance to anthropogenic impacts (e.g. sediment, nutrients). The most significant delineator was water temperature followed by stream size. Indicator species of the aquatic ecosystems were identified and could be evaluated for use as bioindicators in state monitoring programs. We also describe macroinvertebrate community groups from three unique habitats, large river sandbars, fishless springs and prairie stream pools, which contain unique assemblages with rare or at-risk species.

Fish communities: From 483 total sites with 63 species (43 native), analysis revealed 9 and 7 biological community groups for the Missouri and the Yellowstone River drainages, respectively, for a total of 10 distinct species assemblages. Water temperature and stream-size were the dominant variables structuring fish communities. Six of the communities were dominated by warm-water fish; the other four were dominated either by cool or coldwater fish species. Fish community assemblages were related to five major variables: stream order, elevation, gradient or in-stream habitat, and non-native species introductions. A confounding factor in the fish community classification of Montana's river ecosystems was 
the prevalence of stocked game fish, including walleye, northern pike, yellow perch, brown, brook and rainbow trout or exotics, such as carp. Introduced species occurred in most cool-cold water streams and larger warm water rivers, especially those associated with reservoirs. Three of the ten species assemblages (the Northern Redbelly Dace, Large Mainstem River and the Headwater Trout Stream) contained $90 \%$ of Montana's species of concern found in the Missouri drainages.

Aquatic Ecological Systems: Of the 38 aquatic ecological systems, we've delineated 13 ecosystem types based on the presence of specific biological communities overlain on the abiotic template. These represent, at the broader scale, the diversity of lotic ecosystems found within Montana's Missouri drainages. Five of the 13 aquatic ecosystem types are potentially at risk in the state and have already or will become areas of conservation focus.

Overall, we've created a robust, scientifically defensible classification system for Montana's streams and rivers, and their associated biological communities at the Aquatic Ecological System (AES) scale. We've begun to differentiate fully intact prairie fish communities from those in degraded landscapes and are starting to model observed vs. expected $(\mathrm{O} / \mathrm{E})$ values for their use in bioassessments. The macroinvertebrate groups have not been as robust in classifying fully intact communities versus those in impaired ecosystems, especially for the prairie streams. Although the macroinvertebrate communities in the mountain and foothills ecoregions seemed responsive to impairment gradients, and their indicator species should be further evaluated as bioindicators. The report also includes the identification of 10 priority areas in the basin for aquatic biodiversity. Many of these high biointegrity sites with intact native communities were identified within BLM managed lands, and using the classification system, others may be located that have the potential to harbor native species assemblages with sensitive species.

We will continue working with NatureServe ${ }^{1}$, The Nature Conservancy, The Bureau of Land Management, and other partners to:

- Evaluate rarity, distribution and ranking of community groups and ecosystems.

- Further evaluate macroinvertebrate communities and their applicability to the classification.

- Relate reference site community types to management practices or riparian assessment

- Continue to refine biological classifications to classifications using abiotic landscape data at a local watershed level.

\footnotetext{
${ }^{1}$ NatureServe is the parent organization to state Heritage programs. It is currently coordinating efforts among various Heritage programs to develop a national aquatic classification effort.
} 


\section{ACKNOWLEDGMENTS}

We would like to thank The Montana State Office of the Bureau of Land Management (BLM), especially Roxanne Falise and Gayle Sitter, for ongoing support and the funding for Phase 1 of the project. The Nature Conservancy's Freshwater Initiative has also been a substantial source of support and provided matching funds.

Many people have assisted us with this project to date including, but not limited to providing data, scientific discussion and ideas, GIS help, etc. and we would like to offer our sincerest thanks for their assistance. These people and their agencies include:

The Nature Conservancy: Betsy Knightingale (PA TNC), Amy Pearson and Brian Martin (MT TNC) BLM: Joe Platz (Miles City FO)
Montana Natural Heritage Program: Sue Crispin, Greg Kudray, Karen Walker, Marc Jones and Coburn Currier

Montana Fish Wildlife and Parks: Steve Carson and Cindy Sampson

Montana State University: Bob Bramblett, Dan

Gustafson and Melissa Jones

Montana Department of Environmental Quality: David Feldman, Mike Suplee and Rosie de Sada NRIS-Natural Resource Information Systems:

Catherine Love

US Environmental Protection Agency: Tina

Laidlaw and Tom Johnson

US Forest Service: Don Sasse: Custer National Forest Ashland District

All photos in the report were taken by MTNHP personnel, unless otherwise noted. 


\section{TABLe OF CONTENTS}

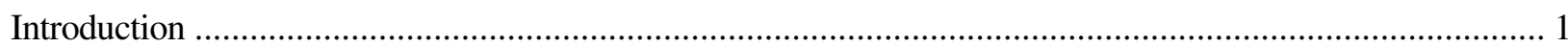

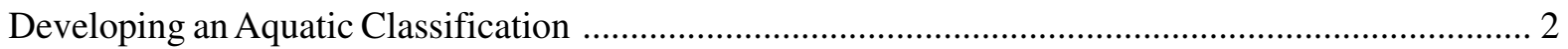

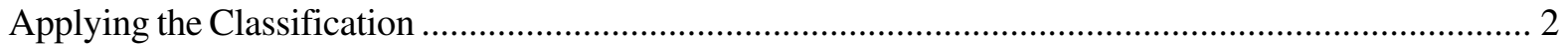

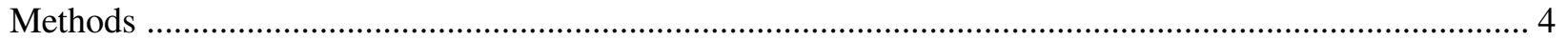

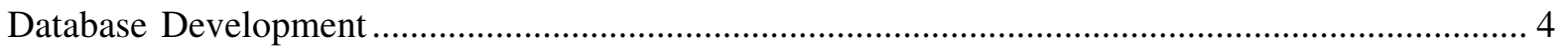

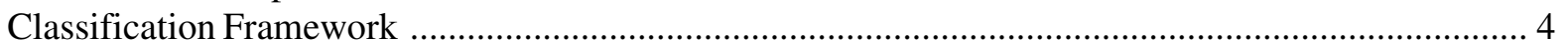

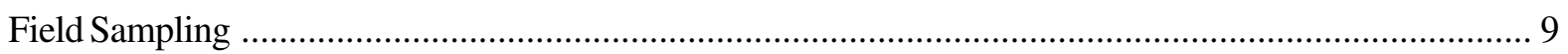

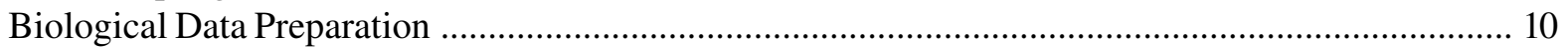

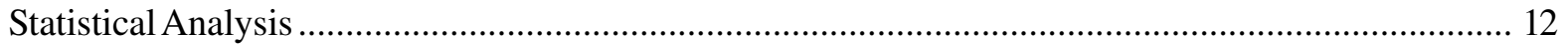

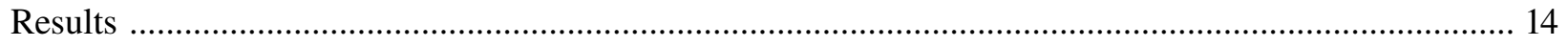

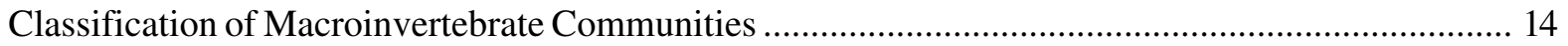

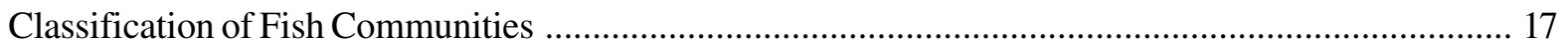

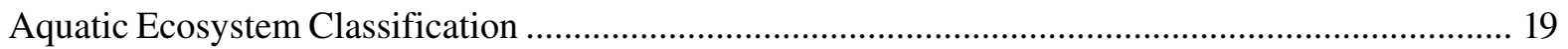

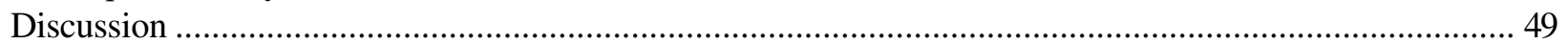

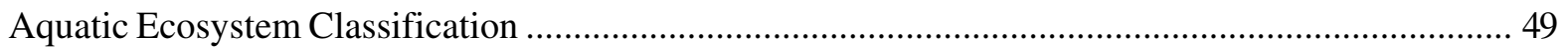

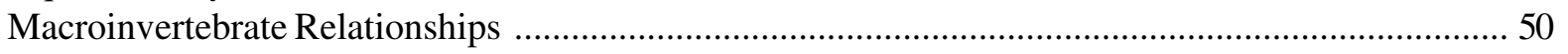

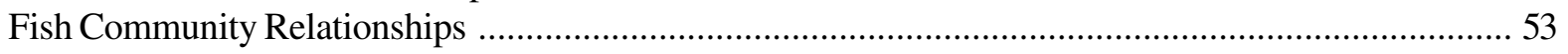

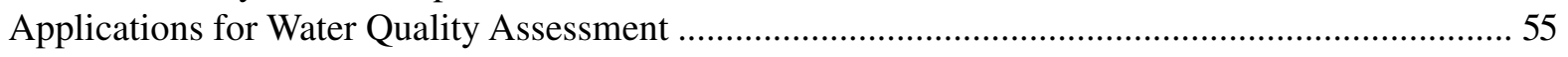

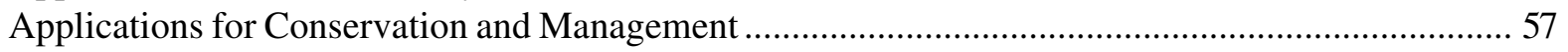

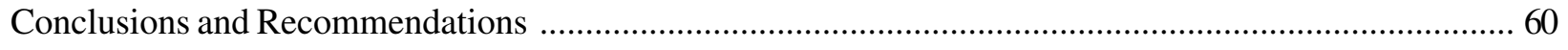

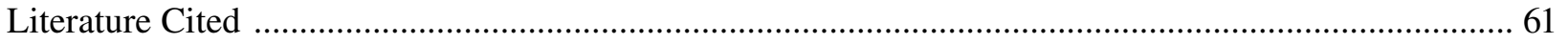

Appendix A. Information on Aquatic Ecological Systems, their occurrences in watersheds, characteristics, and geologic features

Appendix B. Stream Classification and Ecologically Coded Reaches for the Pilot Watersheds

Appendix C. Significant indicator species $(\mathrm{p}<0.05)$ of the macroinvertebrate community groups

Appendix D. Unmodified classification cluster dendrogram of the macroinvertebrate groups

Appendix E. Macroinvertebrate Community Group Descriptions

Appendix F. Fish species recorded from sites within the database

Appendix G. Unmodified output classification cluster dendrogram of the all sites fish database based on categorical abundance

Appendix H. Significant indicator species $(\mathrm{p}<0.05)$ of the fish community groups.

Appendix I. Unmodified output of the fish classification cluster dendrogram from the Missouri River watershed sites

Appendix J. Unmodified output of the fish classification cluster dendrogram from the Yellowstone River watershed sites

Appendix K. Fish Community Group Descriptions

Appendix L. Predicted fish communities for Montana's Missouri warm-water drainages

Appendix M. Predicted fish communities for Montana's Yellowstone warm-water drainages

Appendix N. Global/State Rank Definitions

\section{List OF FigurES}

Figure 1. Montana's Northwestern Great Plains and Northwestern Glaciated Plains ecoregions .............. 1

Figure 2. Simplified schematic of the structure of the stream classification database ............................. 4

Figure 3. Montana's NRIS defined Sub-basins with an enlargement of the Middle Yellowstone EDU ...... 6

Figure 4. Pilot Watersheds used in the stream code classification ........................................................ 8 


\section{LiST OF FiguRES (CONTINUED)}

Figure 5. Multi-habitat macroinvertebrate sampling in Cottonwood Creek (C006- Northern Glaciated stream with a Class-code-211h23) .................................................................... 9

Figure 6. Fish sampling a small D005 prairie stream pool with a $20 \mathrm{ft}$ straight seine ............................. 10

Figure 7. Fish sampling the Powder River, an A003 prairie river, with a $30 \mathrm{ft}$. straight seine .................. 10

Figure 8. Fish \& macroinvertebrate sample locations collected within the watersheds of the study area used in the community classification analysis (some sites with vague location

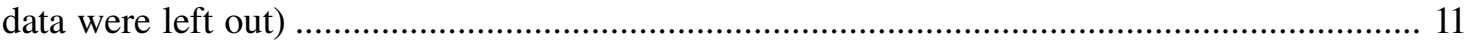

Figure 9. Macroinvertebrate community group locations within the watersheds of the study area .......... 15

Figure 10. NMS macroinvertebrate community ordination with 6 community groups represented.

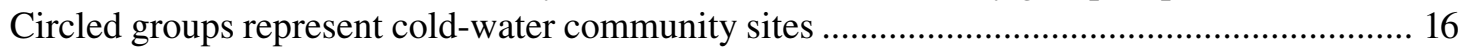

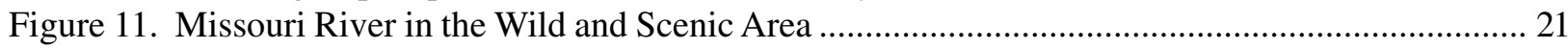

Figure 12. Yellowstone River near Miles City, MT ......................................................................... 21

Figure 13. Powder River (A003) riffle habitat near Moorehead, MT ................................................ 23

Figure 14. Powder River (A003) run habitat near Broadus, MT ................................................... 23

Figure 15. Marias River (A004) riffle habitat near Loma, MT ........................................................ 23

Figure 16. Frenchman Creek (B006) riffle habitat in the BLM badlands ............................................ 25

Figure 17. Battle Creek (B006) run/pool habitat north of Chinook, MT ….......................................... 25

Figure 18. Little Powder River (B005) run/pool habitat near Broadus, MT ......................................... 25

Figure 19. Otter Creek (C005) run/pool habitat near Ashland, MT …................................................ 27

Figure 20. Rotten Grass Creek (C005) moderately degraded Great Plains stream ............................... 27

Figure 21. Hanging Woman Creek (C005) (small Great Plains meandering stream with

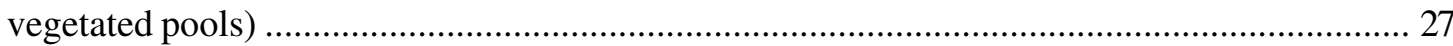

Figure 22. Battle Creek riffle/run upstream reach (C006) (Small Northern Glaciated prairie stream) ..... 29

Figure 23. Cottonwood Creek (C006) severely incised Northern Glaciated prairie stream .................... 29

Figure 24. Whitewater Creek reference condition (C006) (Small Northern Glaciated prairie stream) .... 29

Figure 25. Deer Creek (D005) an intermittent Great Plains stream near Decker, MT ......................... 31

Figure 26. Tooley Creek (E005) a reference condition Great Plains intermittent pool near Otter, MT .... 31

Figure 27. Little Sandy Creek (D006) reference condition Northern Glaciated intermittent

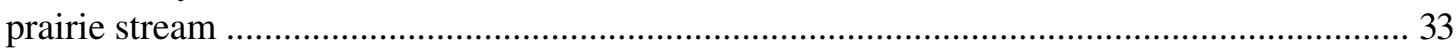

Figure 28. Murray Coulee (D006) slightly impaired Northern Glaciated intermittent prairie stream ........ 33

Figure 29. Cowen Coulee (E006) impaired Northern Glaciated fishless pool ........................................ 33

Figure 30. Cow Creek (S005) reference example within the Custer National Forest ........................... 35

Figure 31. Charcoal Spring (S005) a slightly impaired example within the Custer National Forest .......... 35

Figure 32. Armstrong Spring Creek (S002) in the Paradise Valley. Photo by: Yellowstone Flyfishers, Inc.

Figure 33. DePuy's Spring Creek (S002) in the Paradise Valley. Photo by: DePuy's Spring

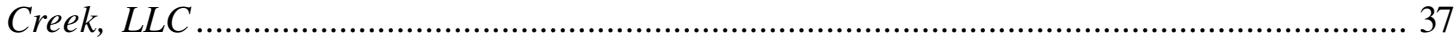

Figure 34. Big Spring Creek aquatic vegetation (S002) near Lewistown, MT ...................................... 37

Figure 35. Big Hole River (B001) an Intermountain Transitional River Ecosystem .............................. 39

Figure 36. Gallatin River (B002) an Intermountain Transitional River Ecosystem ................................ 39

Figure 37. Smith River (B003) an Intermountain Transitional River Ecosystem ..................................... 39

Figure 38. Musselshell River (B004) a dewatered Intermountain Transitional River Ecosystem ............ 39

Figure 39. Pryor Creek (D001) a foothills transitional stream in the Custer National Forest .................. 42

Figure 40. Sweetgrass Creek (C002) a small foothills transitional river near Big Timber, MT ................ 42

Figure 41. Bear Creek (C001) a foothills transitional river with sediment impairment near Belfry, MT .. 42

Figure 42. Tenderfoot Creek (D002) a Small Pristine Mountain Stream in the Belt Mountains .............. 45

Figure 43. Boulder River (D004) a Small Pristine Mountain Stream in the Beartooth Mountains ............ 45 


\section{LiST OF FiguRES (CONTINUED)}

Figure 44. LaMarche Creek (D004) a Small Pristine Mountain Stream, tributary to the Big Hole .......... 45

Figure 45. E. Fork Pintlar Creek (E001) a fishless Alpine Mountain Stream in the Pintlar Mountains ..... 47

Figure 46. Hellroaring Creek (E001) a steep Alpine Mountain Stream in the Beartooth Mountains ........ 47

Figure 47. The Nature Conservancy's Priority Northern Glaciated landscapes (taken from Cooper et. al. 2001)

\section{LIST OF TABLES}

Table 1. Aquatic Classification Framework Hierarchy for the Upper Missouri River Aquatic Zoogeographic Unit.

Table 2. Lithology classes based on Ecological Subsection Units ...................................................... 7

Table 3. Number of sites, watershed occurrences, indicator taxa richness, tolerance values (0-least $-1-=$ most tolerant) and common functional feeding groups for each macroinvertebrate community group 16

Table 4. Fish species group assemblages (SPA) and stream-size affinities for the entire dataset, for the Missouri (MO SPA) and Yellowstone (YL SPA) drainages

Table 5. Aquatic Ecological System types, occurrences in the database an the biological community groups associated with the defined aquatic ecological communities

Table 6. Pryor Creek (C005) fish samples at 6.5 (left) and 13.5 (right) river miles from the confluence with the Yellowstone River: showing temporal and spatial variability

Table 7. Fish data from the Little Missouri River (A003) showing yearly temporal variability of samples taken 2 years apart during the same month in the same river reach

Table 8. Prairie Streams and Rivers within BLM lands that have documented (*) or have the potential to contain high quality aquatic communities.

Table 9. Observed vs. Expected fish communities from sites sampled in selected Northern Glaciated C006 Streams 


\section{INTRODUCTION}

The aquatic ecosystems of Montana's lowerelevation and prairie streams have not been well documented, yet these streams support some of the most intact native fish and invertebrate communities in the state. Prairie streams systems throughout North America have suffered neglect due to a lack of comprehensive study and understanding (Dodds et al. 2004, Matthews 1988). Only recently have there been efforts to sample and describe the interactions among the state's eastern aquatic biota, and relating prairie system aquatic communities to their landscapes. The streams of eastern Montana, as well as those of mountainous ecoregions east of the continental divide, the Middle Rockies and Canadian Rockies of the eastern Missouri drainages, harbor a wide variety of aquatic habitats, providing refuge to hundreds of species of aquatic organisms. Streams and rivers in these ecoregions are home to over half of the state's species of mayflies and caddisflies (D. Gustafson, pers. comm.), and 3/4 of the native species of fishes occurring in the state (Holton 2003). Streams and rivers across Montana, from the mountains to the prairies are vital natural resources to the state and should be managed for the benefit of all, for generations to come.

To increase our understanding of Montana's aquatic ecosystems and the factors that affect those systems, the Montana Natural Heritage Program (MTNHP) recently began a collaborative aquatic community classification project to sample, identify, classify and characterize stream biological communities. Ecosystem classification provides a way to understand the complexity of ecosystems and creates distinctions among ecosystem types based on factors that determine the distribution of ecological processes and biota. We classified biological communities (fish and macroinvertebrates) within the Upper Missouri River Zoogeographic Region with respect to the common repeatable habitat units within the watersheds that they occur. This abiotic/biotic coupling will allow us to predict community types in the scope of watersheds and aquatic ecological units. A large portion of the study region includes the Northwestern Great Plains, Northwestern
Glaciated Plains ecoregions and the lower elevation Montana foothills and valleys (Omernik 1995)

(Figure 1).

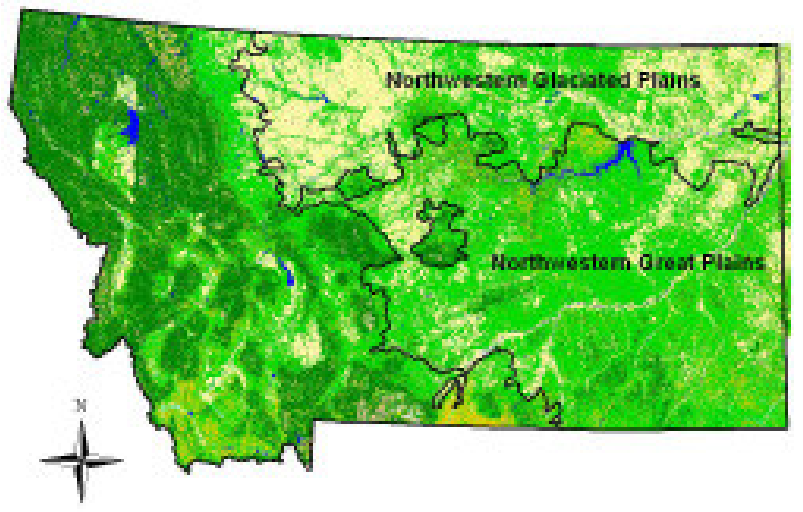

Figure 1. Montana's Northwestern Great Plains and Northwestern Glaciated Plains ecoregion

Effective conservation of aquatic resources requires a system for identifying high quality aquatic systems and communities and understanding the habitat conditions that support them. Until now, Montana lacked a system for defining and classifying these aquatic communities. Working at the community level of aquatic systems presents an opportunity to effectively manage the full range of biodiversity, from vertebrates to invertebrates. Conservation at the community level protects a complex suite of interactions not easily identified and protected through individual species management.

Emerging resource management issues in eastern Montana, such as coal bed methane development, pose new risks and many questions about the impacts to the aquatic and riparian ecosystems, emphasizing the importance of a strong knowledge base to provide scientific answers. The results of this community work will provide a better foundation for understanding the diversity of aquatic stream systems in Montana's Missouri River watershed and maintaining their biological and ecological integrity. Identifying less impacted examples of aquatic community types also provides references to which more impacted examples can be compared for assessment and remediation or restoration. 


\section{Developing an Aquatic Classification}

As with any ecological classification, terrestrial or aquatic, there is a hierarchical component to the methodology (Groves, et al. 2002). This hierarchical framework will enable aquatic scientists to utilize the classification at various spatial scales depending on the level of depth or breadth of information needed to answer their questions (i.e., at the landscape level or the local reach scale).

Rosgen (1996) stream classification protocols are well established (based on abiotic variables), but they are not set in this hierarchical framework. Thus, a Rosgen C3 classified stream means virtually nothing in the scope of aquatic communities, since that $\mathrm{C} 3$ stream could be found in the mountainous ecoregions with cold-water species or in a prairie ecoregion dominated by warm-water communities. We needed a framework that addresses not only local reach scale factors, such as geomorphology, but also the landscape setting that influence aquatic community distribution.

Three primary questions must be answered to establish a working knowledge of the aquatic communities of Montana: 1) What types of communities exist? 2) Where are they found? and 3) Which occurrences represent the best, most viable examples of each community type (Higgins et al. 1998). In ecological classification, a natural community is defined as a recurring assemblage of species that are affected in similar ways by environmental factors (Whittaker 1962). We assume that natural biological communities can be identified from sampling data using qualitative and/ or quantitative analyses (Lyons 1996). Unique biological community types are defined through statistical comparison of taxa that occur together. Community types are characterized either by one taxon that is associated solely with that type, a combination of taxa that are particularly frequent or abundant in one community, and not in others, or dominant taxa (Higgins et al. 1998).
Instead of using the a priori and a posteriori classification frameworks separately, the Montana Natural Heritage Program will use both approaches systematically, and concurrently. This method will test and refine abiotically derived stream classes with analysis of biological community data as we proceed. The process of developing an "a posteriori" community classification framework involves compiling the best available information and integrating biological assemblages onto an "a priori" derived watershed template, as described below (Higgins et al. 2005).

1. Assemble existing statewide datasets on aquatic systems and correlate them with the abiotic macrohabitat classification to evaluate, validate and modify the framework as necessary.

2. Apply this framework using spatial analysis tools to differentiate and delineate preliminary stream ecosystem types from GIS data layers of landscape-scale abiotic information.

3. Classify riverine ecosystems into distinct ecological units at multiple spatial scales.

4. Document the physical parameters and biological composition (including characteristic assemblages or indicator species and the habitat affinities or requirements of those species) for each stream ecosystem type. Develop finescale community types or species assemblages.

5. Predict and map the distribution of species assemblages (by stream segment) throughout the watersheds in which they occur.

\section{Applying the Classification}

A statewide aquatic community classification has many applications. Classification is extremely useful for determining the expected community of organisms in a reference condition (relatively unaltered aquatic habitats). Conservation efforts benefit from knowledge of rare community types, 
or those that are likely to contain species of concern or the full compliment of native species.

Identifying reference aquatic communities is critical for conservation and biomonitoring programs. By modeling reference aquatic communities, biologists can limit predict the community type that exists in a location given the ecoregion, watershed, geology, hydrology and land use, and thereby reduce the need for intensive sampling programs (Hawkins 2004). Watershed conservation can use reference sites (representative of high quality biological communities) to establish standards for expected goals of stream protection and restoration (Knightingale 2003).

Additionally, this project will generate a large database of community information with locations referenced in a GIS, which can provide "on demand" inventories of communities to state agencies and conservation organizations. By mapping these communities and providing descriptions of the diversity of the aquatic systems, information can be effectively organized and integrated into an ecosystem management approach.

A well-designed community classification framework helps facilitate the development and use of biological criteria for evaluating and restoring the health of aquatic ecosystems (Hawkins and Norris 2000, Hawkins and Vinson 2000). Effective aquatic community classification can categorize water body types for field surveys of threatened and endangered species, delineate the location of assessment areas, and identify beneficial uses and the degree of impairment of aquatic systems. Biological classification of aquatic systems identifies reference conditions for impaired areas and establishes biological based goals for watershed restoration and benchmarks for watershed monitoring programs. Aquatic community data allows for a more holistic, system approach to conserving aquatic diversity than efforts on single species management. 


\section{MethodS}

\section{Database Development}

A Microsoft Access database was created to house the standardized aquatic data assembled from existing statewide datasets (Montana Department of Environmental Quality, MTDEQ; Fish Wildlife and Parks, FWP; US Geological Survey's National Water Quality Assessment Program (NAWQA) sites and EPA's Environmental Monitoring and Assessment Protocols, EMAP) and recently collected samples by the Montana Natural Heritage Program. The database was modeled after the publicly available EDAS (Ecological Data Application System v.3) database application (TetraTech Inc. 2000). For each site visit the database stores information about sampling locations, biological (fish and macroinvertebrate) and habitat data collected, autecology information about organisms, data source, sampling methodology, and spatial attribute data (Figure 2). This database will be maintained and updated as part of the Montana Natural Heritage Program information system.

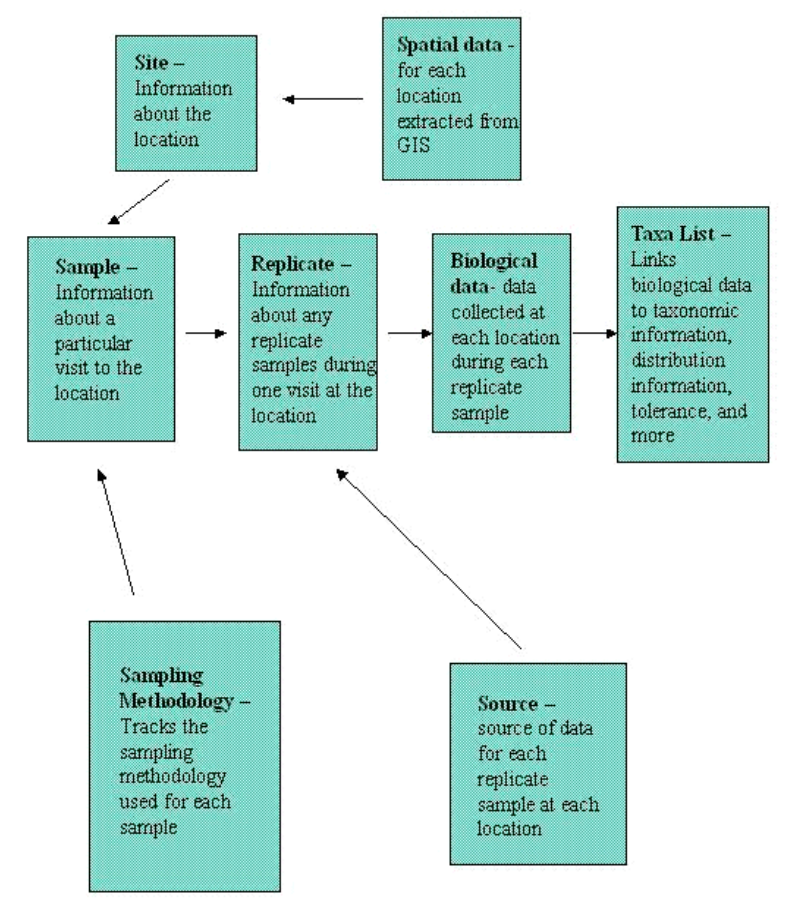

Figure 2. Simplified schematic structure of the stream classification database (following Knightingale 2003)

\section{Classification Framework}

\section{Geographic Scope}

The Missouri River drains one-sixth of the United States and encompasses 529,350 square miles. It flows 2,341 miles from its headwaters at the confluence of the Gallatin, Madison, and Jefferson Rivers at Three Forks, Montana, to its confluence with the Mississippi River (USGS 2004). With such a large river system, classifying the drainages without a nested hierarchy would be overwhelming. Therefore, we began by defining the area of study within the state of Montana, although at the broadest level, the classification system will be applicable to most areas within the upper Missouri River drainages, including Saskatchewan, Wyoming, North and South Dakota, which contain similar landform and ecological patterns.

The study area is within the Upper Missouri River Freshwater Ecoregion (Abell et al. 2000), which has an area of $678,741 \mathrm{~km}^{2}$, and encompasses all of Montana east of the continental divide. Our framework consists of 4 hierarchical levels under the Upper Missouri River Aquatic Zoogeographic Unit: the Ecoregion, the Ecological Drainage Unit (EDU), Aquatic Ecological Systems (AES) within an EDU, and macrohabitats within an AES (Higgins et al. 2005)(Table 1).

\section{Ecological Drainage Units (EDU's)}

Ecological Drainage Units are groups of watersheds that share common zoogeographic history (based primarily on fish distributions), physiographic and climatic characteristics. We used an EDU classification based on the Natural Resource Information Systems (NRIS) sub-basin classification (NRIS 2004) that has boundaries which are aggregated USGS 4th code HUC's (8 digit code) (Figure 3). Based on fish distributional patterns in Holton (2003), we combined the Northern Glaciated regions into the Milk/Marias/ Glaciated-Lower Missouri EDU (10.5) and the central watersheds into the Musselshell/ Middle Missouri (10.4). Numbers of $4^{\text {th }}$ code watersheds within each EDU can vary from as few as 4 in the 
Table 1. Aquatic Classification Framework Hierarchy for the Upper Missouri River Aquatic Zoogeographic Unit (following Higgins et al. 2005)

\begin{tabular}{|c|c|c|c|}
\hline Level & Examples & Description & Separation Factors \\
\hline Ecoregion & $\begin{array}{l}\text { 1) Northwestern Great Plains } \\
\text { 2) Northern Glaciated Plains }\end{array}$ & $\begin{array}{l}\text { Similar climate and physiography } \\
\text { that corresponds to broad } \\
\text { vegetation regions }\end{array}$ & $\begin{array}{l}\text { Glaciated vs. non- } \\
\text { glaciated landscape }\end{array}$ \\
\hline $\begin{array}{l}\text { Ecological } \\
\text { Drainage Units } \\
\text { (EDU) }\end{array}$ & $\begin{array}{l}\text { 1) Lower Yellowstone River } \\
\text { 2) Upper Yellowstone River } \\
\text { 3) Milk River /Marias/ } \\
\text { Glaciated-Lower Missouri } \\
\text { 4) Missouri Headwaters } \\
\text { (Madison, Jefferson, Gallatin), } \\
\text { 5) Little Missouri }\end{array}$ & $\begin{array}{l}\text { Aggregates of watersheds that } \\
\text { share ecological, biological, and } \\
\text { aquatic zoogeographical } \\
\text { characteristics. Stratification } \\
\text { units are 8-digit HUC's as } \\
\text { defined by the USGS. Within } \\
\text { each EDU there is a regional } \\
\text { subset of aquatic ecosystem types }\end{array}$ & $\begin{array}{l}\text { Physiography, } \\
\text { zoogeography, } \\
\text { watershed }\end{array}$ \\
\hline $\begin{array}{l}\text { Aquatic } \\
\text { Ecological } \\
\text { Systems (AES) }\end{array}$ & $\begin{array}{l}\text { 1) Medium sized perennial } \\
\text { prairie streams. } \\
\text { 2) Small transitional foothills } \\
\text { streams } \\
\text { 3) Large intermontane river } \\
\text { systems, direct tributaries to the } \\
\text { Missouri }\end{array}$ & $\begin{array}{l}\text { Hydrological subunits of EDU's. } \\
\text { Defined by landscape position of } \\
\text { a stream size-class within } 1 \text { or } 2 \\
\text { stream orders that represent a } \\
\text { dynamic assemblage of aquatic } \\
\text { communities }\end{array}$ & $\begin{array}{c}\text { Size, drainage network } \\
\text { position, connectivity, } \\
\text { hydrologic regime, } \\
\text { geology }\end{array}$ \\
\hline $\begin{array}{l}\text { Macrohabitat } \\
\text { Type } \\
\text { (Class_code) }\end{array}$ & $\begin{array}{l}\text { 1) Meandering, low gradient, } \\
\text { riffle/pool plains stream 2) } \\
\text { Medium gradient, foothills } \\
\text { beaver-pond influenced stream }\end{array}$ & $\begin{array}{l}\text { Different valley segment types of } \\
\text { stream reaches (think stream } \\
\text { reach of } 30 \mathrm{~km} \text { ), within segments, } \\
\text { relative homogeneous. Finest } \\
\text { scale classification unit on the } \\
\text { maps. }\end{array}$ & $\begin{array}{c}\text { Surficial geology, } \\
\text { drainage network } \\
\text { position, connectivity, } \\
\text { hydrologic regime, } \\
\text { geology }\end{array}$ \\
\hline $\begin{array}{l}\text { Community } \\
\text { Species } \\
\text { Assemblages } \\
\text { (SPA) }\end{array}$ & $\begin{array}{l}\text { 1) Warm-water, low-gradient } \\
\text { plains stream community. } \\
\text { 2) Transitional, foothills-plains } \\
\text { aquatic community }\end{array}$ & $\begin{array}{l}\text { Coarse level of biological } \\
\text { community organization. } \\
\text { Corresponds spatially to Aquatic } \\
\text { Ecological Systems. }\end{array}$ & $\begin{array}{c}\text { Taxa that are } \\
\text { diagnostic of groups or } \\
\text { associations (e.g. cold- } \\
\text { water stenotherms, } \\
\text { tolerant warm-water } \\
\text { stream fish) }\end{array}$ \\
\hline Associations & $\begin{array}{l}\text { 1) Headwater plains } \\
\text { riffle community } \\
\text { 2) Headwater prairie pool fish } \\
\text { communities }\end{array}$ & $\begin{array}{l}\text { Finest scale of classification. } \\
\text { Corresponds spatially to within } \\
\text { macrohabitat units. }\end{array}$ & $\begin{array}{l}\text { Repeating, distinct } \\
\text { species assemblages }\end{array}$ \\
\hline
\end{tabular}

Little Missouri to nine in the case of the Middle Yellowstone (Figure 3) to 26 in the Milk/Marias/ Glaciated-Lower Missouri EDU. This grouping system allowed us to compare data coverage at a level above the $4^{\text {th }}$ code watershed level. For example, the Musselshell/ Middle Missouri EDU has 257 sample points in the database, while the Little Missouri EDU has 48 sample points, but both have on average 12 sample sites per $4^{\text {th }}$ code watershed. 

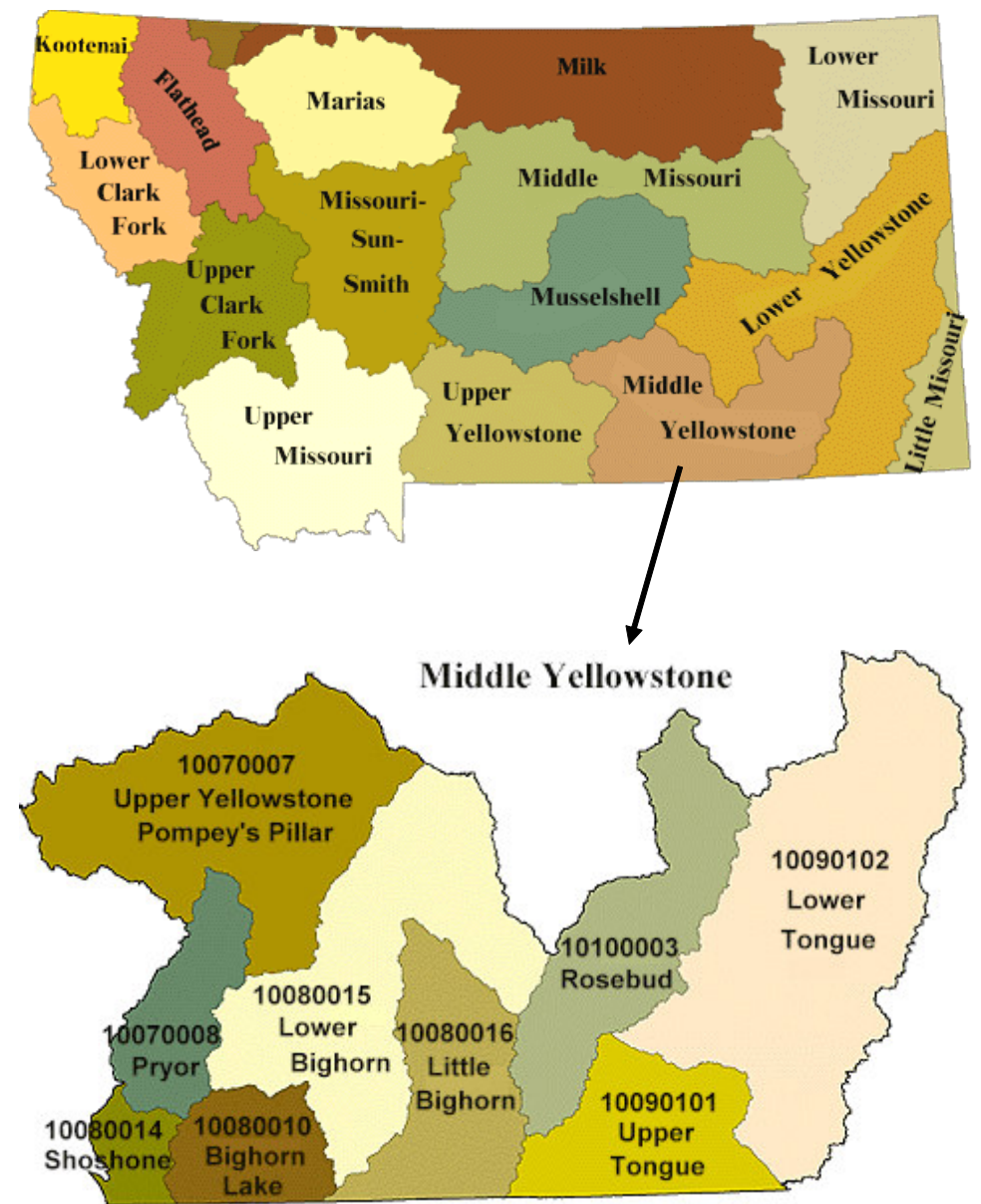

Ecological Drainage Units (EDU's)

10.2. Upper Missouri Headwaters

10.3. Missouri Sun-Smith

10.4. Musselshell/ Middle Missouri

10.5. Milk/ Marias/Glaciated-Lower Missouri
10.7. Upper Yellowstone

10.8. Middle Yellowstone

10.9. Lower Yellowstone

10.11. Little Missouri

Figure 3. Montana's NRIS defined Sub-basins with an enlargement of the Middle Yellowstone EDU

\section{Aquatic Ecological Systems}

Aquatic Ecological Systems (AES) are stream networks within an EDU that have similar geomorphology and environmental processes (e.g. hydrologic, geologic, nutrient and temperature regimes)(Groves et al. 2002). Standard attributes used to classify aquatic ecological systems and macrohabitats are defined in Higgins et al. (2005), and include stream size, gradient, connectivity to other water bodies and underlying lithology (Table 2).

We used five variables were used to represent the attributes contributing to the lotic (streams and rivers) aquatic community types within an ecoregion and applied them to the NHD reach codes within a GIS:

1. Stream order- corresponds to the controlling factors of stream size, flow regime and channel morphology. The classes reflect broad changes in the stream habitat and flow rates: Class $1-1^{\text {st }}$ or $2^{\text {nd }}$ order, 2-3 $3^{\text {rd }}$ or $4^{\text {th }}$ order, $3-5^{\text {th }}$ or $6^{\text {th }}$ order, and $4-7^{\text {th }}$ or larger order streams.

2. Elevation-corresponds to species limits, changes in temperature, degree, slope and specific species distributions: Class $\mathbf{1}<1000 \mathrm{~m}$ ( $<3280 \mathrm{ft}$ ), 2 1000-1600m 
$(\sim 3280-5200 \mathrm{ft}), 31600-2500 \mathrm{~m}(\sim 5200-$

$8200 \mathrm{ft}), 4>2500 \mathrm{~m}$ (>8200ft)

3. Lithology- corresponds to flow regime (in conjunction $\mathrm{w} /$ topography to determine groundwater vs. surface water), water chemistry, stream substrate and morphology. We used Ecological Subsections (Nesser et. al. 1997) as our lithology code in the classification process (Table 2).
4. Downstream connectivity- corresponds to the local zoogeography by considering species pool differences in the downstream habitats. Classes: 0 stock pond (dead end), $\mathbf{1}$ lake or reservoir, $\mathbf{2}$ stream, $\mathbf{3}$ river

5. Upstream connectivity- corresponds to the effects of upstream segments on both hydrologic regime and water chemistry. Classes: 0 unconnected, 1 lake or reservoir, 3 river

Table 2. Lithology classes of the Montana Foothills and Valleys and Prairie ecoregions used in the classification and based on Nesser et al. (1997)

\begin{tabular}{|c|c|c|}
\hline $\begin{array}{c}\text { Geology } \\
\text { code } \\
\end{array}$ & $\begin{array}{l}\text { Ecological } \\
\text { Subsection } \\
\end{array}$ & Geology Description \\
\hline $1 \mathrm{a}$ & 331Da & Rocky Mountain Front Foothills-Elevation 3,400-6,000ft \\
\hline $1 b$ & $331 \mathrm{Db}$ & Montana Isolated Mountain Ranges-2,500-5,500ft \\
\hline $1 \mathrm{c}$ & $331 \mathrm{Dc}$ & Belt Mountain Foothills-Elevation-3,500-5,500ft \\
\hline $1 \mathrm{e}$ & 331De & Little Belt Mountain Foothills-Elevation 3,500-5,000ft \\
\hline 1f & 331Df & $\begin{array}{l}\text { Missouri River Breaks-1,800-4,400ft, steeply dissected sedimentary } \\
\text { clay-shale, sandstone and siltstone }\end{array}$ \\
\hline $1 \mathrm{~h}$ & $331 \mathrm{Dh}$ & $\begin{array}{l}\text { Montana Glaciated Plains-1,800-4,400ft, tills/shale and gravel/alluvium } \\
\text { terraces, fans and floodplains }\end{array}$ \\
\hline 2 & $331 \mathrm{Ea}$ & $\begin{array}{l}\text { Missouri Choteau-outwash and stream terraces, river sediments overlie } \\
\text { shale siltstone and sandstone-1,650-3030ft }\end{array}$ \\
\hline $3 a$ & $331 \mathrm{Fb}$ & $\begin{array}{l}\text { Shale Scablands-dissected shale plains in calcareous sedimentary, - } \\
2650-4,100 \mathrm{ft}\end{array}$ \\
\hline $3 b$ & $331 \mathrm{Fc}$ & $\begin{array}{l}\text { Pierre Shale Plains-shale sandstone plains, with alluvium terraces and } \\
\text { floodplains, river breaks along the lower Yellowstone and Powder } \\
\text { Rivers, } 1000-3,500 \mathrm{ft}\end{array}$ \\
\hline $3 \mathrm{c}$ & $331 \mathrm{Fd}$ & $\begin{array}{l}\text { Missouri Plateau-sedimentary sandstone terraces and plains, with } \\
\text { alluvium fans and floodplains, }, 1000-3,500 \mathrm{ft}\end{array}$ \\
\hline $4 \mathrm{a}$ & $331 \mathrm{Ga}$ & $\begin{array}{l}\text { Montana High Plains and Foothills--shale sandstone plains, with } \\
\text { alluvium terraces and floodplains, 2,900-6,000ft }\end{array}$ \\
\hline $4 \mathrm{~b}$ & $331 \mathrm{~Gb}$ & $\begin{array}{l}\text { Montana Shale Plains-dissected shale, sandstone plains, hills, terraces in } \\
\text { sedimentary, } 1,500-3,500 \mathrm{ft}\end{array}$ \\
\hline $4 \mathrm{c}$ & $331 \mathrm{Gc}$ & $\begin{array}{l}\text { Powder River Basin/Breaks/Scoria Hills--shale sandstone dissected } \\
\text { plains, with alluvium terraces and floodplains, } 2,100-4,900 \mathrm{ft}\end{array}$ \\
\hline $4 d$ & $331 \mathrm{Gd}$ & $\begin{array}{l}\text { Wolf Mountains-strongly rolling shale/sandstone plains and hills, 3,500- } \\
5,000 \mathrm{ft}\end{array}$ \\
\hline $4 \mathrm{e}$ & $331 \mathrm{Ge}$ & $\begin{array}{l}\text { Montana Sedimentary Plains--shale/sandstone plains and hills, with } \\
\text { alluvium terraces and floodplains, } 2,100-4,150 \mathrm{ft}\end{array}$ \\
\hline $5 \mathrm{a}$ & M331Ba & $\begin{array}{l}\text { Bighorn Sedimentary Mountains (MT)-5,000-10,500ft, Mountainsides, } \\
\text { foothills, fans and terraces in sedimentary sandstone, limestone and } \\
\text { shale }\end{array}$ \\
\hline $5 b$ & M331Bb & $\begin{array}{l}\text { Bighorn Sedimentary Mountains (WY)-5,000-10,500ft, Mountainsides, } \\
\text { foothills, fans and terraces in sedimentary sandstone, limestone and } \\
\text { shale }\end{array}$ \\
\hline
\end{tabular}


We used these classification methods to define 38 aquatic ecological systems for the Missouri drainages of Montana. In the coarse filter approach, we wanted to encompass all types of lotic systems across Montana using a wellestablished framework (Higgins et al. 2005, Groves, 2002). This involved permutations of six stream size classes ${ }^{2}$ overlain on the six major ecological subsections with a few finer scale divisions (see Appendix A). The prairie spring Aquatic Ecological Systems (S005 and S006, Appendix A) were treated differently in the classification since they will usually become losing streams (flow subsurface) less than $100 \mathrm{~m}$ from their source, although some may flow for longer distances $(\sim 1-2 \mathrm{~km})$ and in wetter years maintain connectivity to downstream reaches.

\section{Pilot Watershed Selection}

Five USGS 8-digit Hydrologic Unit Code ( $4^{\text {th }}$ codeHUC) watersheds (Figure 4) were selected for the classification to develop, test and refine the methodology. These watersheds offer good representation of the larger diversity of watersheds across the prairie regions of the state, in terms of ecological, geological, and physiographic factors (Figure 4). First, we assessed the quality and quantity of the available data for these watersheds to evaluate completeness of the data, and highlight potential patterns and problems such as data gaps. Data gaps were addressed in the pilot watersheds with community sampling field visits in the summer of 2003 and continued in 2004.

The second step in applying the abiotic classification to the pilot watersheds was to assign a five-digit code to the NHD labeled stream reaches. This code was concatenated in the database from the five assigned physical attributes of the stream's size and watershed position (e.g. 125a23-represents a $1^{\text {st }}$ or $2^{\text {nd }}$ order stream at an elevation of 1000-1600m in the Bighorn sedimentary mountains with a downstream connection to another stream and an upstream connectivity to another stream reach).

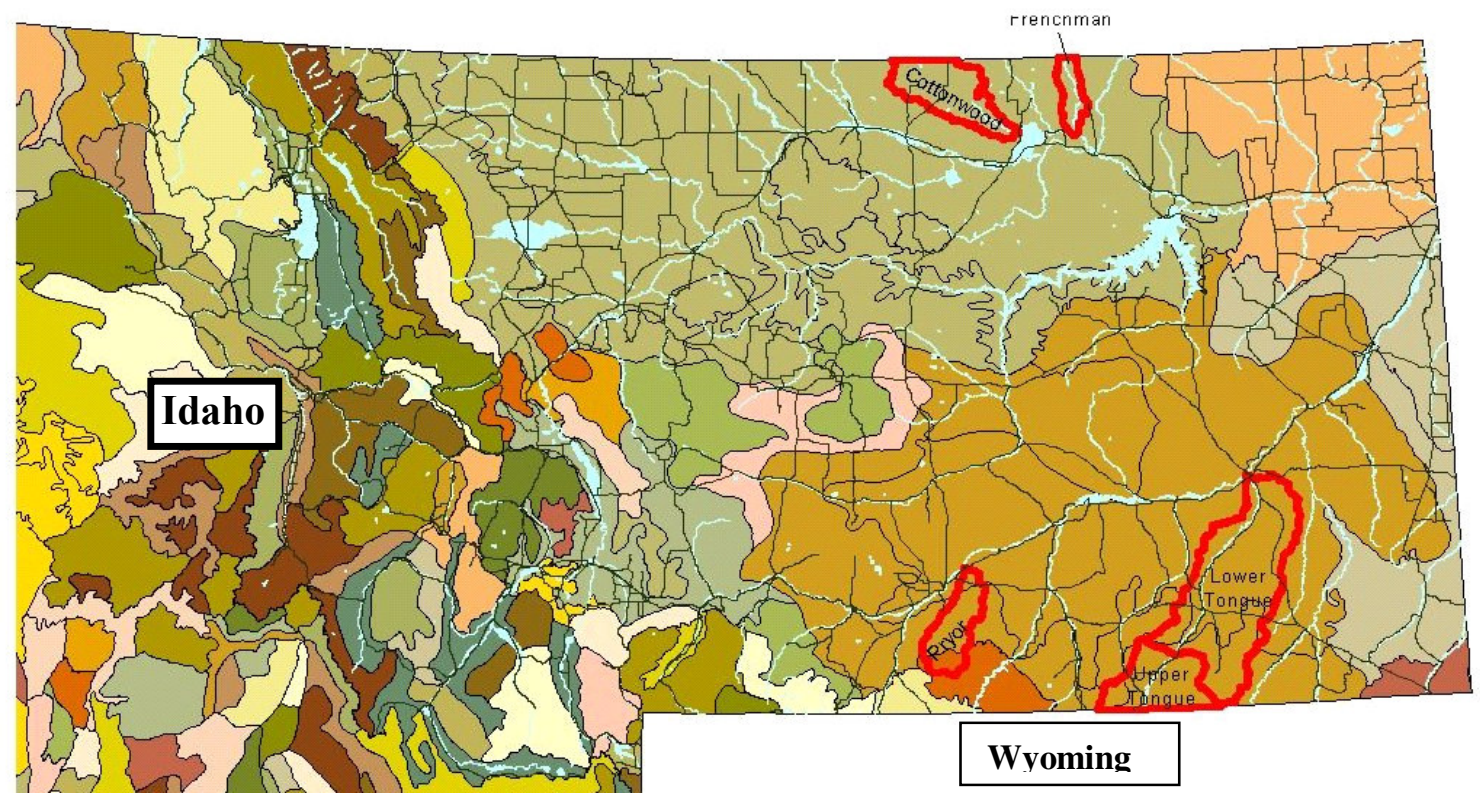

Figure 4. Pilot Watersheds used in the stream code classification

\footnotetext{
${ }^{2}$ stream length, Strahler order (Strahler 1957) and hydrology were the prominent defining factors in assigning the first letter (A$\mathrm{E}$ and $\mathrm{S}$ ) of the AES code, large rivers ("A" class rivers) were $>200$ river miles; medium rivers ("B" class) were at least 100 miles long; small rivers (C class) were between 30-100 miles; headwater creeks and streams (D and E classes) are usually less than 30 miles; and spring dominated streams are in the $\mathrm{S}$ class
} 


\section{Field Sampling}

Community inventories were conducted in the pilot watersheds and adjacent watersheds to fill data gaps for fish and benthic macroinvertebrates. Full community sampling (fish and macroinvertebrates) in 2003 occurred at two sites on Hanging Woman Creek and two sites on Pryor Creek; we also sampled eight sites for macroinvertebrates only in the Middle Yellowstone EDU. During the 2004 field season, community sampling occurred at 36 sites (plus 6 sites for macroinvertebrates only) in four watersheds in the Northern Glaciated Plains (Cottonwood, Frenchman, Battle, and Whitewater watersheds).

Field sampling was conducted using the EPA/BLM protocols for macroinvertebrates and habitat assessments (Lazorchak et al. 1998) and the FWP fish sampling protocols. Reaches (150-300 m) that best represented the characteristics of the stream served as the sampling unit (Barbour et al. 1999). The number of sites sampled in an AES varied with the quality and quantity of the existing data. Representative samples were sought from all AES types. Considerable future sampling will be required to represent all types of stream macrohabitat class codes across the broad landscape of eastern Montana.

On-site habitat assessments were conducted using the rapid assessment protocol developed by Barbour et al. (1999). Additional habitat assessment metrics were also collected as recommended in Meador et al. (1993) and Bukantis (1998). The goal of these evaluations was to characterize reach geomorphology, in-stream habitat, and other characteristics that influence aquatic community composition. Habitat assessments were performed during the same visit as the biological sampling.

Macroinvertebrates were collected from all habitats that we could wade within the sampling reach of the streams (Figure 5). Sampling involved multi-habitat and targeted habitat sampling methods described in Barbour et al. (1999) and EMAP/ BLM protocols (Lazorchak 1998). Substrate, vegetation, woody debris and bank-side areas within the transects were sampled qualitatively with a 500 micron D-frame net. A total of ten randomized $0.5 \mathrm{~m}$ jabs or kicks were conducted within the reach, allowing 30 seconds per kick and composited into one sample. All organisms in the net were washed on a 500 micron sieve, transferred to a 1 liter Nalgene bottle, labeled and preserved in $95 \%$ ethanol for shipment to the BLM National Aquatic Monitoring Center in Logan, Utah or brought to the MTNHP lab in Helena for processing.

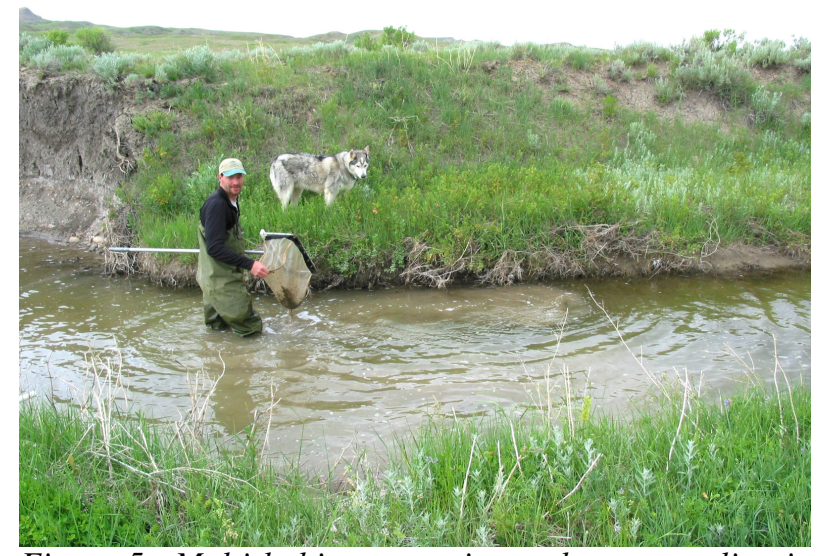

Figure 5. Multi-habitat macroinvertebrate sampling in 2004 in Cottonwood Creek (C006-a perennial Northern Glaciated prairie stream, Class-code211h23)

Caton trays were used to sub-sample macroinvertebrates collected in the field (Caton 1991). This involved taking a $6 \mathrm{~cm} \times 6 \mathrm{~cm}$ subdivision of the sample and picking all the macroinvertebrates within the grid. Additional subdivisions were taken until 500 or more organisms were retained from the field sample. Aquatic insects were identified to genus or species level, and other organisms were identified to their lowest practical taxonomic level (Bukantis 1998).

Fish sampling protocols required the positioning of upstream and downstream block nets at the ends of the reach (300m or $40 \mathrm{x}$ wetted width), but most of the time shallow sections and/or riffle areas were sufficient to prevent fish from escaping while the pool areas were being seined from the upstream to the downstream direction with a 20-30 ft 1/4 inch straight seine, depending on wetted width (see Figures 6 and 7). Fish were transferred to holding 
buckets, identified to species, enumerated in the field, examined for external anomalies (e.g. deformities, eroded fins, lesions, and tumors), and then released. Young-of-the-year fish less than 20 millimeters in length were noted on the field sheet (not included in the totals), and released. Voucher specimens were only taken in the case of uncertain field identifications of the silvery minnows, Hybognathus spp., or Northern redbelly dace hybrids, Phoxinus spp., which were preserved in $10 \%$ buffered formalin and identified in the lab. Vouchers were submitted to the Montana State University fish collection.

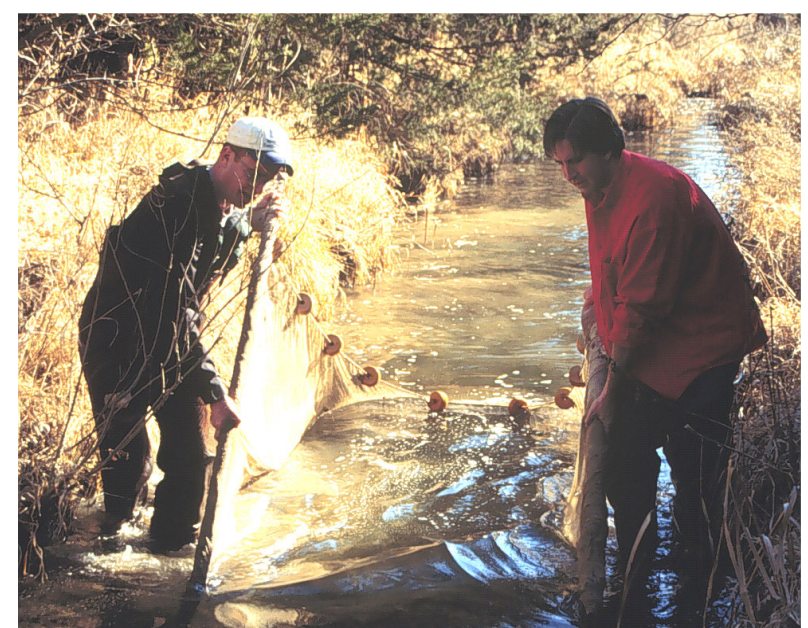

Figure 6. Fish sampling a small C005 prairie stream pool with a $20 \mathrm{ft}$ straight seine

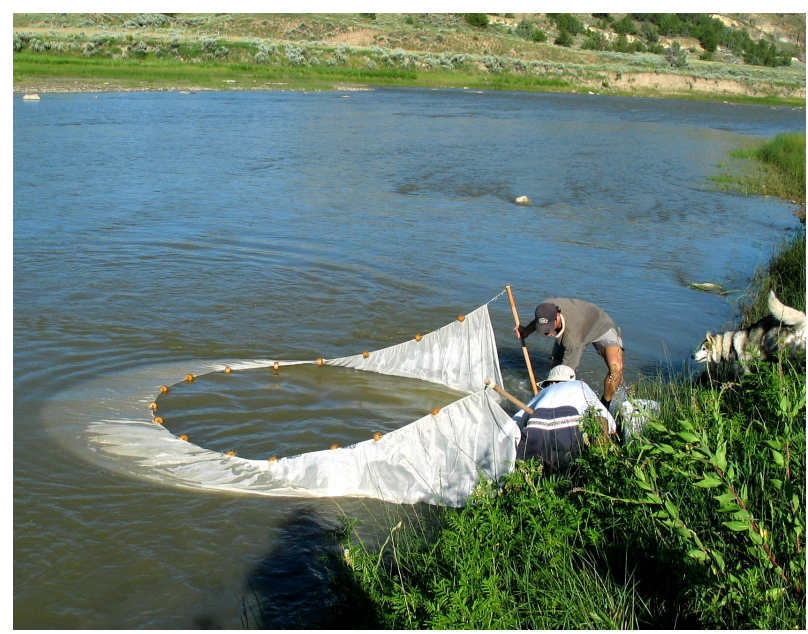

Figure 7. Fish sampling the Powder River, a large A003 prairie river with a $30 \mathrm{ft}$. straight seine

\section{Biological Data Preparation}

\section{Fish and Macroinvertebrate Samples}

The final set of fish and macroinvertebrate samples available for the community classification analysis were well distributed within watersheds and across the study region (see Figure 8 ). The macroinvertebrate data included 428 samples from 289 unique sites and 444 unique taxa. These data were collected using several different methods, usually MT DEQ (Bukantis 1998) or the EMAP (Lazorchak 1998) protocols, and primarily during the 1990's or more recently for the prairie sites.

Fish survey data in the mountain and foothill ecoregions has been collected since the 1970's (FWP MFISH 2004), while most of the prairie fish data has been collected in the last 5 years. The fish database (which combines data from the MFISH database and MTNHP total community surveys) includes 463 sample sites from all stream and river types (i.e., $1^{\text {st }}$ order mountain headwater streams to the mainstem Yellowstone or Missouri Rivers) with 63 fish species (see Appendix F for species list). The fish data was split into the two separate zoogeographic regions (Yellowstone and Missouri River drainages), however the whole dataset was analyzed to determine differences in assemblages across the two widely separated basins.

Several different methods have been used by agencies to assign habitat rating condition or assessment scores for sites (Barbour et al. 1999, Bukantis 1998, FWP MFISH 2004, Plafkin et al. 1989). To standardize the habitat rating data, we calculated the site score as a percentage of the best possible habitat score for the particular ranking protocol. For instance, using the EPA habitat assessment protocols in Barbour et al. (1999, Appendix 1, Form 3) a site score of 180, would be converted (180/200) to become a score of $90 \%$.

\section{$\underline{\text { Standardization of Taxonomy }}$}

All fish data included in the analysis were identified to the species level using currently accepted 
Figure 8. Fish \& macroinvertebrate sample locations within the watersheds of the study area used in the community classification analysis (some sites with vague location data were left out)

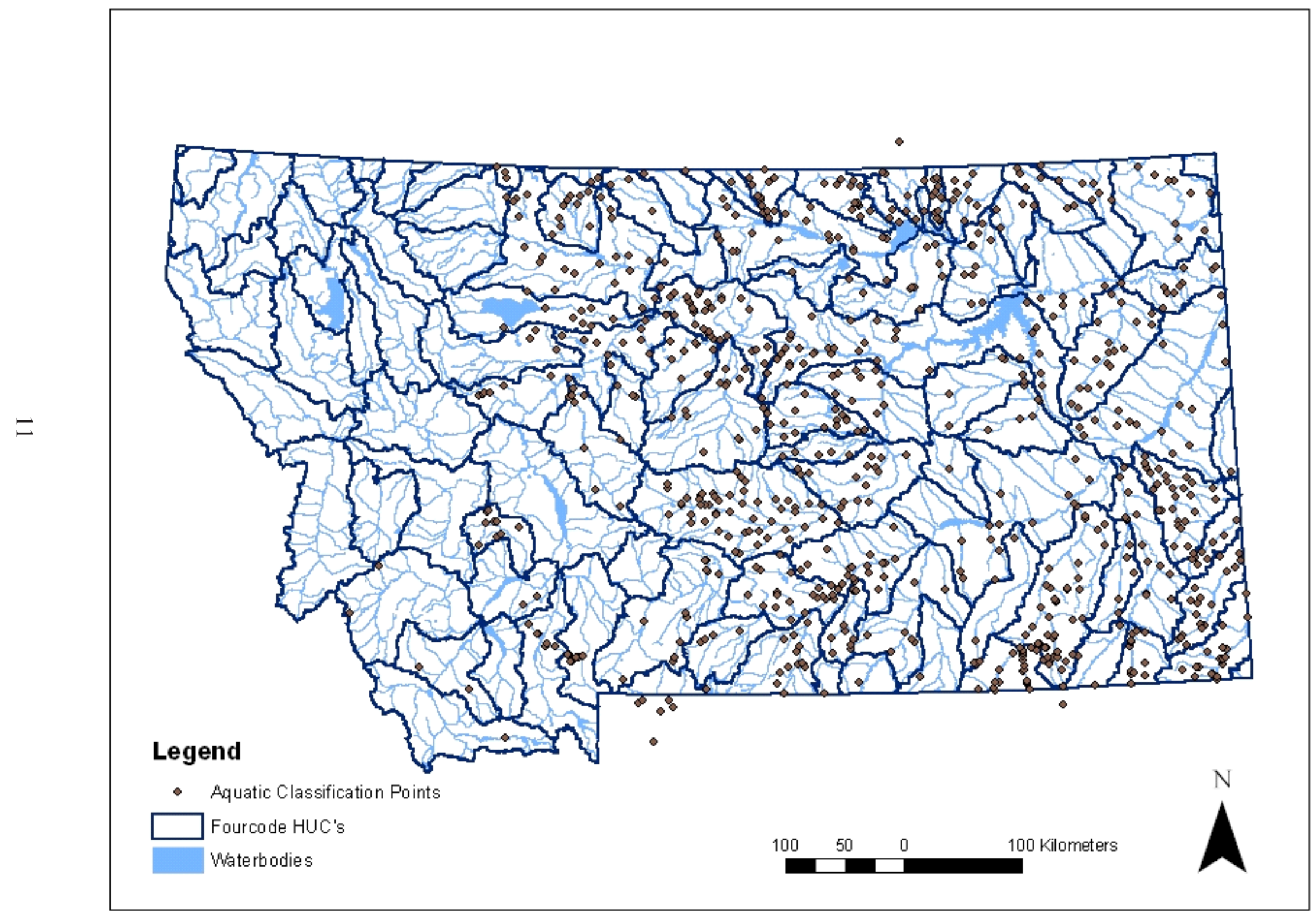


nomenclature; therefore no standardization of the taxonomy was necessary.

The taxonomy of the macroinvertebrate dataset was checked to include currently accepted nomenclature. For macroinvertebrate data some of the available datasets had species level identification for insects, while others were identified by genera. To eliminate any inflation in species richness at a site, samples that reported taxa at the genus and species level were lumped into the species name, unless there was an obvious note in the data indicating that the genus level identification represented something different (usually a genus determination results from specimens losing some of the diagnostic characters needed to identify to the species level, but are not actually different - e.g. 10 Baetis sp. and 12 Baetis tricaudatus $=22$ Baetis tricaudatus). Unfortunately, taxa in the Dipteran family Chironomidae were identified to various levels of taxonomy; we didn't want to lose valuable information at the genus level (Epler 2003) by backing all taxa to the family-level across datasets, so we accepted the Chironomidae as identified.

Another method of correcting for taxa inflation is data apportioning (commonly called "data stuffing") (Marshall 2003). The procedure divides the abundance of higher-level taxonomic units (parent taxa) proportionally among the finer-level taxa composing each parent taxon (composite taxa) in each sample. It appeared that some of the data reported in MT DEQ reports had been "stuffed" prior to reporting. For example, samples rarely contain mayflies that have the necessary parts to identify all of them to the species-level. However, many of the reports had data with all mayflies identified to species. It is likely that assumptions similar to "data stuffing" were used to lump partially identified taxa into a probable species. We believe that this method introduces the least amount of error, and preserves the integrity of the data. Therefore, it was the method we used to prepare the dataset for analysis.

For an example of data stuffing, consider a sample containing 10 Baetidae, 10 Baetis, 10 Baetis bicaudatus, $10 \mathrm{~B}$. tricaudatus, 10 Acentrella, and
10 A. insignifcans. The raw species richness for 60 individuals would be 6.0 and it is possible that all 6 are distinct species. However, it is more likely that some of the individuals identified in the higher taxonomic units (e.g. Baetidae) are immature or damaged specimens of one of the species (e.g. Baetis bicaudatus). To reduce this error, we apportioned the data into the lowest taxonomic units possible. Thus, the abundances of the sample became: Baetidae 0.0, Baetis 0.0, B. tricaudatus 18, B. bicaudatus 18, Acentrella 0.0, A. insignificans 24 . Notice that the conservative estimate of taxa richness, 3.0, is lower than the raw richness value of 6.0. Moreover, notice that none of the individuals were excluded from the analysis (total abundance $=60$ ).

Macroinvertebrate tolerance values for use in impairment determinations in many biomonitoring metric indicies were taken from DEQ (2005) and Barbour et al. (1999).

Fish and macroinvertebrate data were converted to categorical abundance or presence/absence for analysis (Marchant 1990). Community structure is detectable using presence-absence information in large-scale studies of diverse communities (Gauch 1982). Macroinvertebrate data were analyzed using both presence/absence and relative abundance data.

Analyses were run on both the full dataset, and subsequently on datasets from which rare species (found in less than 5\% of the sites sampled) were removed. Studies have shown that rare species have very little effect on results of community classification or multivariate analyses (Gauch 1982). But to avoid any complications that rare species may present in the analysis (McCune and Grace 2002), they were removed for the final analysis.

\section{Statistical Analysis}

PC-ORD (MjM Software Design 2002) was used for the multivariate analysis. Species-area curves were created from the data to determine if there was adequate sampling to characterize a particular taxa group. Outlying sites that were greater than 
2.5 standard deviations from the mean were removed from analysis (McCune and Grace 2002).

Cluster analysis was conducted on the fish and macroinvertebrate data sets separately. The cluster analysis used flexible beta linkage $(2=-$ 0.25) (McCune and Grace 2002, Hawkins and Norris 2000, Feminella 2000) and Sorensen's distance measure (Sorensen 1948).

Indicator species analysis (ISA) was applied to groups defined using cluster analysis and ordination to find significant indicators of the community types and to develop lists of general taxa that occur in the community type. ISA calculates the frequency and relative abundance of a particular species within each group (Dufrene and Legendre 1997). ISA highlights significant indicator species, based on Monte Carlo simulations of frequency and relative abundance of taxa in community groups. However, some communities may have species frequently occurring that are not primary significant indicators for that group, these are often ubiquitous species found in more general habitat conditions. Any significant indicators (with $\mathrm{p}<0.05$, unless otherwise noted) were used as indicators of that particular community group.
We also used ISA to come up with the optimal number of community groups defined by the cluster analysis. After examining the dendrogram for obvious breakpoints indicating different groups, we ran ISA on a number of groups above and below this predicted ideal group number. Then we averaged the p-values for the entire species list, and the group number with the lowest average $\mathrm{p}$ value was chosen as the defining group number as recommended by McCune and Grace (2002)

Non-metric multidimensional scaling (NMS) was used for data ordination. NMS has been shown to be the most generally effective method of ordination for ecological community data (McCune and Grace 2002). The NMS used Sorensen's distance, which is viewed as optimal for ordination of presence/absence data (McCune and Grace 2002). The number of dimensions to view the data in ordination space was determined by evaluating the NMS stress of various solutions (McCune and Grace 2002). There has not been a fixed statistical criterion developed for selecting the appropriate number of dimensions (Kruskal and Wish 1978), but it has been shown that stress of 20 or below indicates a stable resulting solution (McCune and Grace 2002). The results of the ordination were viewed to determine whether the same general trends in grouping that appeared in the cluster analyses occurred with this method. 


\section{RESULTS}

\section{Classification Of \\ Macroinvertebrate Communities}

Classification of macroinvertebrate communities used 289 macroinvertebrate samples containing over 440 unique invertebrate taxa (see Appendix C). The lowest average $p$-value from ISA analysis indicated that the optimal number of macroinvertebrate groups was $12(\mathrm{p}=0.1224)$. The largest group was comprised of 52 sites. The smallest group, consisting of eight sites, was unique to the transitional, foothills streams (AES types: C001, C007) (Table 3). Macroinvertebrate groups 11 and 12 were the most widespread across the prairies, while groups, 58 and 105 were confined to two watersheds each (Figure 9). Distribution of these 12 macroinvertebrate communities across the landscape of Montana can be seen in Figure 9. Communities varied in their distribution across pilot watersheds, from three groups in the Frenchman Watershed to five and six community groups in the Upper and Lower Tongue River Watersheds, respectively. Distribution of communities within all pilot watersheds is included in Appendix B. The NMS analysis validated communities defined by the initial cluster analysis (overall mean stress of 18.6), with macroinvertebrate community groups generally clustering by stream size, water temperature and flow regime (Figure 10). We assigned names to the macroinvertebrate species assemblages/community groups, reflecting those environmental parameters:

\section{Group SPA 1 - Medium Coolwater Transitional Assemblage \\ Group SPA 3 - Transitional Prairie River Assemblage \\ Group SPA 4 - Traditional Trout Stream Assemblage \\ Group SPA 9 - Prairie Stream Assemblage Group SPA 11 - Large Prairie River Assemblage \\ Group SPA 12 - Prairie Pool Assemblage \\ Group SPA 37 - Filtering Collector Assemblage}

Group SPA 38 - Large River Slow Current Assemblage

Group SPA 40 - Medium Prairie River Side Channel Community

Group SPA 58 - Pristine Mountain Stream Community

Group SPA 90 - Medium Mountain Stream Community

Group SPA 105 - Small Foothills Transitional Assemblage

Appendix E provides full community descriptions of these types, including representative indicator species (full indicator species list in Appendix C) and habitats characteristic of the associated macroinvertebrate assemblages. Taxa representative of each community group tended to occur repeatedly and have similar relative abundance among sites within a community group.

The most tolerant macroinvertebrate assemblage with an average tolerance value of 7.0 was the Medium Prairie River Side-Channel Community. The Prairie Stream (SPA 9) and Prairie Pool (SPA 12) Assemblage indicator species had average tolerance values of 6.9 and 6.4, respectively. The lowest (least tolerant or most sensitive) indicator species tolerance value was 1.2 reported by the Pristine Mountain Stream Assemblage (SPA 58). Although not reported in the classification due to its absence in the samples, the unique sand-dwelling mayfly assemblage (SDM, see Appendix E) is included here. This large-river assemblage includes indicator species: Analetris eximia,

Raptoheptegenia cruentata, Lachlania saskatchewanensis, Anepeorus rusticus, Ametropus neavei and Homoeoneuria alleni, and is most closely associated with the Large Prairie River Assemblage. We delineated two additional unique macroinvertebrate communities: the Small Perennial Fishless Prairie Spring Community and the Isolated Fishless Pool Community (Appendix E). 


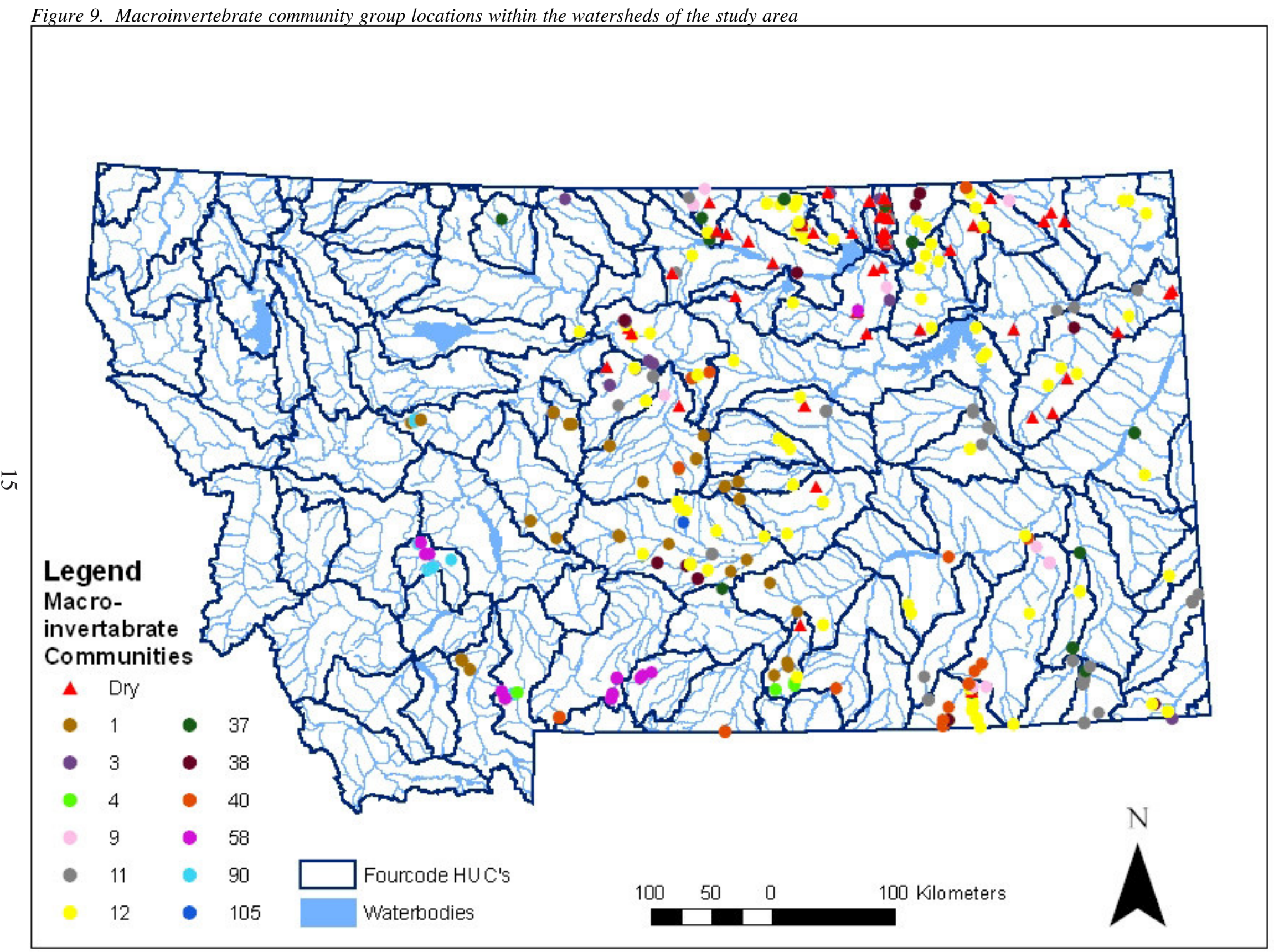




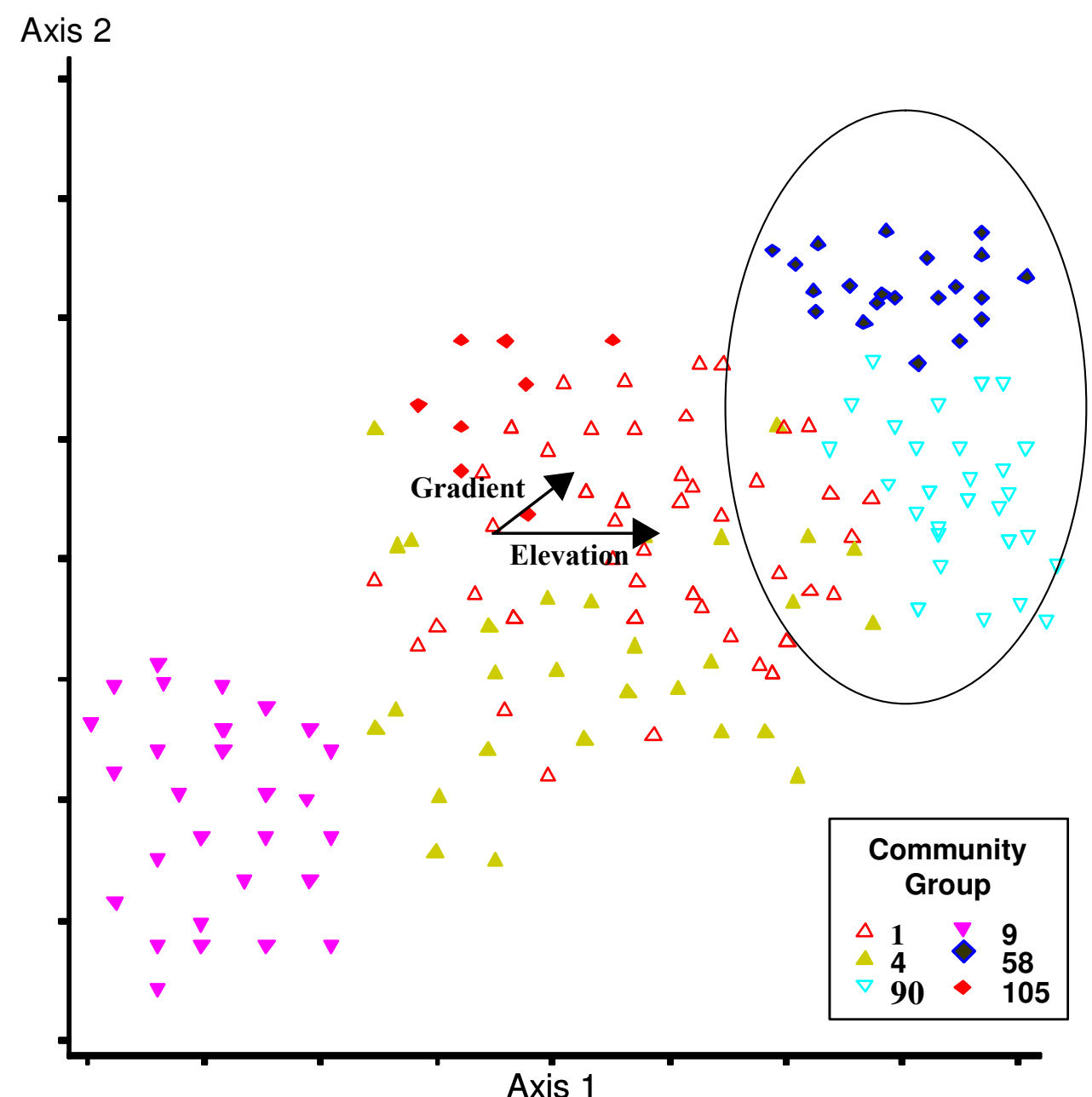

Figure 10. NMS macroinvertebrate community ordination with two environmental variables (6 community groups represented). Circled groups represent high elevation, cold-water community sites

Table 3. Number of sites with each macroinvertebrate assemblage, pilot watershed occurrences, indicator taxa richness and tolerance values (0-intolerant-10-most tolerant) and common functional feeding groups for each community group $(F C=$ filterer-collector, $P R=$ predator, $C G=$ collector-gatherer, $S H=S h r e d d e r, S C=S c r a p e r)$

\begin{tabular}{|c|c|c|c|c|c|c|c|c|c|c|c|c|}
\hline $\begin{array}{l}\text { Species Assemblage/ } \\
\text { Community Group }\end{array}$ & 1 & 3 & 4 & 9 & 11 & 12 & 37 & 38 & 40 & 58 & 90 & 105 \\
\hline Number of sites & 52 & 14 & 11 & 22 & 36 & 44 & 28 & 21 & 41 & 15 & 32 & 8 \\
\hline $\begin{array}{l}\text { Number of pilot } \\
\text { watersheds group } \\
\text { occurs }\end{array}$ & 1 & 3 & 1 & 5 & 5 & 5 & 3 & 2 & 5 & 0 & 0 & 0 \\
\hline $\begin{array}{l}\text { Total number of } \\
\text { indicator taxa. }\end{array}$ & 12 & 16 & 15 & 11 & 9 & 18 & 6 & 14 & 13 & 25 & 32 & 45 \\
\hline $\begin{array}{l}\text { Mean tolerance value } \\
\text { of indicator taxa }\end{array}$ & 3.7 & 5.5 & 2.8 & 6.9 & 5.0 & 6.4 & 4.8 & 3.0 & 7.0 & 1.2 & 2.7 & 3.7 \\
\hline Most common & FC & CG & SH & CG & SC & CG & FC & FC & CG & SH & SH & SC \\
\hline functional feeding & $\mathrm{CG}$ & $\mathrm{FC}$ & $\mathrm{SC}$ & $\mathrm{FC}$ & $\mathrm{FC}$ & $\mathrm{FC}$ & PR & $\mathrm{SC}$ & PR & $\mathrm{SC}$ & $\mathrm{SC}$ & $\mathrm{CG}$ \\
\hline $\operatorname{group}(\mathbf{s})$ & $\mathrm{SH}$ & PR & PR & $\mathrm{SC}$ & & $\mathrm{SC}$ & $\mathrm{CG}$ & PR & $\mathrm{FC}$ & & PR & SH \\
\hline
\end{tabular}




\section{Classification of Fish Communities}

Classification of fish communities was based on 463 total sample sites with 63 (43 native) fish species. Ten fish community groups or species assemblages (SPA) were identified from the data, with four further subdivisions also recognized as ecologically meaningful (Table 4 and Appendix G). Names were also assigned to the fish species assemblages/community groups:

\section{Group SPA 1 - Large Warmwater River Assemblage \\ Group SPA 2 - Medium Warmwater River Assemblage \\ Sub-Group SPA 2c - Transitional River Assemblage \\ Sub-Group SPA 18 - Brook Stickleback Assemblage \\ Sub-Group SPA 20 - Core Prairie Stream Assemblage \\ Group SPA 3 - Warmwater Sunfish Assemblage \\ Group SPA 4 - Northern Redbelly Dace Assemblage \\ Group SPA 5 - Large Mainstem River Assemblage}

Group SPA 6 - Big Hole River Assemblage Group SPA 7 - Traditional Trout Stream Assemblage Sub-Group SPA 7a - Headwater Trout Stream Assemblage

Group SPA 8 - Bull Trout Assemblage Group SPA 9 - Creek Chub Assemblage Group SPA 10 - Yellowstone Mountain Stream Assemblage

The lowest average p-values from ISA analysis showed the optimal number of fish groups for the whole data set was nine $(\mathrm{p}=0.1224)$. Cluster analysis of sites within the Missouri River dataset resulted in nine distinct cluster communities (ISA analysis $\mathrm{p}=0.1341$ ) (Appendix F). Cluster analysis of sites from within the Yellowstone Dataset resulted in 7 distinct cluster communities (ISA analysis $\mathrm{p}=0.1712$ ) (Appendix G). Species assemblage fidelity was consistent across the drainages, except for three species in the Large Warmwater River Assemblage, two species forming the Yellowstone Mountain Stream Assemblage, and the Northern Glaciated Plainsdominant species of the Northern Redbelly Dace and Brook Stickleback Assemblages (Table 4).

Table 4. List of species group assemblages (SPA), group membership and stream affinities for the entire dataset, for the Missouri (MO SPA) and Yellowstone (YL SPA) drainages. An asterisk (*) after the common name represents an Indicator Species of that assemblage, while an (*) after the SPA represents an indicator within that drainage only. Stream size codes: A -large rivers, $B$-medium rivers, $C$-small rivers and large streams, $D$-small streams. L-ponds and lakes

\begin{tabular}{lllllllc}
\hline Common Name & Scientific Name & $\begin{array}{l}\text { Species } \\
\text { Code }\end{array}$ & Native & SPA & $\begin{array}{l}\text { MO } \\
\text { SPA }\end{array}$ & $\begin{array}{c}\text { YL } \\
\text { SPA }\end{array}$ & $\begin{array}{c}\text { Stream } \\
\text { Size }\end{array}$ \\
\hline Bigmouth buffalo & Ictiobus cyprinellus & ICTICY & Yes & 1 & 1 & 1 & A \\
Creek chub & Semotilus atromaculatus & SEMOATR & Yes & 1 & $9 *$ & 2 & B \\
Northern pike & Esox lucius & ESOX & No & 1 & 1 & 3 & A -> B \\
Plains Killifish & Fundulus zebrinus & FUNDZE & No & 1 & 9 & 1 & B \\
Sauger * & Stizostedion canadense & STIZCA & Yes & 1 & 1 & 1 & A \\
Smallmouth bass & Micropterus dolomieu & MICRDO & No & 1 & 1 & 1 & A \\
Smallmouth buffalo & Ictiobus bubalus & ICTIBU & Yes & 1 & 1 & 1 & A \\
Stonecat $*$ & Noturus flavus & NOTFLA & Yes & 1 & 1 & 1 & A -> B \\
Channel catfish * & Ictalurus punctatus & ICTAPUN & Yes & 1 & 1 & 1 & A -> B \\
Walleye & Stizostedion vitreum & STIZVIT & No & 1 & 1 & 3 & A \\
Yellow perch & Percaflavescens & PERCFLA & No & 1 & 1 & 3 & A \\
Emerald shiner * & Notropis atherinoides & NOTRAT & Yes & 1 & 1 & 1 & A \\
\hline
\end{tabular}


Table 4. Continued

\begin{tabular}{|c|c|c|c|c|c|c|c|}
\hline Common Name & Scientific Name & $\begin{array}{l}\text { Species } \\
\text { Code }\end{array}$ & Native & SPA & $\begin{array}{l}\text { MO } \\
\text { SPA }\end{array}$ & $\begin{array}{r}\text { YL } \\
\text { SPA }\end{array}$ & $\begin{array}{l}\text { Stream } \\
\text { Size }\end{array}$ \\
\hline Goldeye * & Hiodon alosoides & HIODAL & Yes & 2 & $1 *$ & $1 *$ & $\mathrm{~A}$ \\
\hline River carpsucker $*$ & Carpiodes carpio & CARPCARP & Yes & 2 & $1 *$ & $1 *$ & A \\
\hline Shorthead Redhorse * & Moxostoma macrolepidotum & MOXOMA & Yes & 2 & $1 *$ & $1 *$ & A \\
\hline Common carp * & Cyprinus carpio & CARP & No & 2 & 2 & 1 & $\mathrm{~A}->\mathrm{B}$ \\
\hline Flathead Chub * & Platygobio gracilis & PLATGR & Yes & 2 & 2 & 1 & $\mathrm{~A}->\mathrm{B}$ \\
\hline Goldfish & Carassius auratus & CARAAU & No & 2 & 3 & 3 & $\mathrm{~L}$ \\
\hline Green sunfish * & Lepomis cyanellus & LEPOCY & No & 2 & 2 & 2 & B \\
\hline Plains minnow * & Hybognathus placitus & HYBOPL & Yes & 2 & 2 & 1 & $A->B$ \\
\hline Sand shiner $*$ & Notropis stramineus & NOTRST & Yes & 2 & 2 & 2 & $\mathrm{~B}$ \\
\hline Black bullhead & Ameiurus melas & AMEIME & No & 2 & 2 & 2 & B \\
\hline Spottail shiner & Notropis hudsonius & NOTRHU & No & 2 & 3 & 3 & B \\
\hline $\begin{array}{l}\text { Western silvery } \\
\text { minnow }\end{array}$ & Hybognathus argyritis & HYBOAG & Yes & 2 & 2 & 1 & $A->B$ \\
\hline Fathead minnow $*$ & Pimephales promelas & PIMEPR & Yes & 20 & 20 & 20 & $\mathrm{C}$ \\
\hline Longnose dace $*$ & Rhinichthys cataractae & RHINCA & Yes & 20 & 20 & 20 & $\mathrm{~B}->\mathrm{C}$ \\
\hline White sucker $*$ & Catostomus commersoni & CATOCO & Yes & 20 & 20 & 20 & $\mathrm{~B}->\mathrm{C}$ \\
\hline Lake chub $*$ & Couesius plumbeus & COUEPL & Yes & 20 & 20 & $26^{*}$ & $\mathrm{C}$ \\
\hline Black crappie & Pomoxis nigromaculatus & POMONI & No & 3 & 3 & 3 & $\mathrm{~L}$ \\
\hline Bluegill & Lepomis macrochirus & LEPOMA & No & 3 & 3 & 3 & $\mathrm{~L}$ \\
\hline Golden shiner & Notemigonus crysoleucas & NOTECR & No & 3 & 3 & 3 & $\mathrm{~L}$ \\
\hline Largemouth bass & Micropterus salmoides & MICRSAL & No & 3 & 3 & 3 & $\mathrm{~L}$ \\
\hline Pumpkinseed* & Lepomis gibbosus & LEPOGI & Yes & 3 & 3 & 3 & $\mathrm{~B}$ \\
\hline Rock bass* & Ambloplites rupestris & AMBLRU & No & 3 & na & 3 & B \\
\hline White crappie & Pomoxis annularis & POMOAN & No & 3 & 3 & 3 & $\mathrm{~B}$ \\
\hline Yellow bullhead & Ameiurus natalis & AMENAT & Yes & 3 & 3 & 3 & $\mathrm{~B}$ \\
\hline Brook stickleback & Culaea inconstans & CULAIN & Yes & 4 & $18 *$ & 4 & $\mathrm{C}$ \\
\hline Iowa darter & Etheostoma exile & ETHEEXIL & Yes & 4 & 18 & 4 & $\mathrm{C}$ \\
\hline Brassy minnow & Hybognathus hankinsoni & НYВOHА & Yes & 20 & 18 & 2 & $\mathrm{~B}->\mathrm{C}$ \\
\hline Northern redbelly dace* & Phoxinus eos & PHOXEOS & Yes & 4 & 4 & 4 & $\mathrm{C}$ \\
\hline $\begin{array}{l}\text { Northern redbelly dace } \\
\text { X Finescale dace }\end{array}$ & $\begin{array}{l}\text { Phoxinus eos } x \text { Phoxinus } \\
\text { neogaeus }\end{array}$ & PHOXEOSX & Yes & 4 & 4 & na & $\mathrm{C}$ \\
\hline Finescale Dace & Phoxinus neogaeus & PHOXNEO & Yes? & 4 & 4 & na & $\mathrm{C}$ \\
\hline Pearl dace* & Margariscus margarita & MARGMARG & Yes & 4 & 4 & na & $\mathrm{C}$ \\
\hline Blue sucker $*$ & Cycleptus elongatus & CYCLEL & Yes & 5 & 5 & 5 & A \\
\hline Burbot & Lota lota & LOTALOTA & Yes & 5 & 6 & 5 & A \\
\hline Freshwater drum * & Aplodinotus grunniens & APLOGRUN & Yes & 5 & 5 & 5 & A \\
\hline Paddlefish * & Polyodon spathula & POLYSPAT & Yes & 5 & 5 & 5 & A \\
\hline Pallid sturgeon * & Scaphirhynchus albus & SCAPALBU & Yes & 5 & 5 & 5 & A \\
\hline Shortnose gar & Lepisosteus platostomus & LEPIPLAT & Yes & 5 & 5 & 5 & A \\
\hline
\end{tabular}


Table 4. Continued

\begin{tabular}{|c|c|c|c|c|c|c|c|}
\hline Common Name & Scientific Name & $\begin{array}{l}\text { Species } \\
\text { Code }\end{array}$ & Native & SPA & $\begin{array}{l}\text { MO } \\
\text { SPA }\end{array}$ & $\begin{array}{r}\text { YL } \\
\text { SPA }\end{array}$ & $\begin{array}{l}\text { Stream } \\
\text { Size }\end{array}$ \\
\hline Shovelnose sturgeon $*$ & $\begin{array}{l}\text { Scaphirhynchus } \\
\text { platorynchus }\end{array}$ & SCAPPLAT & Yes & 5 & 5 & 5 & A \\
\hline Sturgeon chub & Macrhybopsis gelida & MACRGE & Yes & $5^{*}$ & 9 & 2 & A \\
\hline Sicklefin Chub * & Macrhybopsis meeki & MACRME & Yes & 5 & 5 & 5 & A \\
\hline Fluvial arctic grayling* & Thymallus arcticus & THYAR & Yes & 6 & 6 & na & B \\
\hline Redside Shiner * & Richardsonius balteatus & RIBA & Yes & 6 & 6 & na & B \\
\hline Brook trout $*$ & Salvelinus fontinalis & SALFON & No & 7 & 7 & 7 & $\mathrm{C} \rightarrow>\mathrm{D}$ \\
\hline Brown trout $*$ & Salmo trutta & SALTRU & No & 7 & 7 & 7 & $\mathrm{~B}->\mathrm{C}$ \\
\hline Golden trout & Oncorhynchus aquabonita & ONCOAQ & No & 7 & 7 & $10^{*}$ & $\mathrm{C}$ \\
\hline Longnose sucker & Catostomus catostomus & CATOCA & Yes & 7 & 2 & 7 & B \\
\hline Mottled sculpin * & Cottus bairdi & COTBA & Yes & 7 & 7 & 7 & $\mathrm{~B} \rightarrow \mathrm{D}$ \\
\hline Mountain sucker & Catostomus platyrhychus & CATOPL & Yes & 7 & 2 & 7 & $\mathrm{~B}$ \\
\hline Mountian Whitefish * & Prosopium williamsoni & PROSWILL & Yes & 7 & 7 & 7 & $\mathrm{~B}->\mathrm{C}$ \\
\hline Rainbow trout $*$ & Oncorhynchus mykiss & ONCOMYK & No & 7 & 7 & 7 & $\mathrm{~B}->\mathrm{C}$ \\
\hline Westslope Cutthroat* & Oncorynchus clarki lewisi & ONCOCLL & Yes & 7 & 7 & 7 & $\mathrm{C}->\mathrm{D}$ \\
\hline Yellowstone Cutthroat & Oncorynchus clarki bouvieri & $i$ ONCOCLB & Yes & 7 & 7 & $10^{*}$ & $\mathrm{C} \rightarrow \mathrm{D}$ \\
\hline Bull trout $*$ & Salvelinus confluentus & SALVCON & Yes & 8 & na & na & $\mathrm{B}->\mathrm{C}$ \\
\hline Slimy Sculpin * & Cottus cognatus & COTTCO & Yes & 8 & na & na & $\mathrm{B}->\mathrm{C}$ \\
\hline
\end{tabular}

\section{Aquatic Ecosystem Classification}

Of the 38 abiotic aquatic ecological system types, we integrated the fish and macroinvertebrate groups to delineate 13 aquatic ecosystem types based on the presence of specific biological communities and zoogeographic differences (Table
5). These ecosystem types are composed of relatively broad biological community categories, which are more significantly defined by the fish assemblages than the macroinvertebrates, and the species were predominantly related to water temperature, stream size and permanence of surface flow. Descriptions of these aquatic ecosystems are presented below.

Table 5. Aquatic Ecological System types, occurrences in the database and the biological community groups (SPA) associated with the defined aquatic ecological communities

\begin{tabular}{|c|c|c|c|c|}
\hline $\begin{array}{l}\text { Aquatic Ecological } \\
\text { System }\end{array}$ & AES types & Fish SPA & $\begin{array}{c}\text { Macroinvertebrate } \\
\text { groups }\end{array}$ & $\begin{array}{l}\text { Number of } \\
\text { Occurrences }\end{array}$ \\
\hline $\begin{array}{l}\text { Large Valley River } \\
\text { Ecosystem }\end{array}$ & A001, A002 & $1,2,5$ & $\begin{array}{l}\text { 3, 11, 37, } 38 \\
40, \text { SDM }^{* * *}\end{array}$ & 17,27 \\
\hline $\begin{array}{l}\text { Large Prairie River } \\
\text { Ecosystem }\end{array}$ & A003, A004 & $1,2,3,9$ & $\begin{array}{l}\text { 3, 11, 37, } \\
\text { 40, SDM }\end{array}$ & 20,11 \\
\hline $\begin{array}{l}\text { Medium Prairie River } \\
\text { Ecosystem }\end{array}$ & $\begin{array}{c}\text { B005, B006 } \\
\text { B008 }\end{array}$ & $1,2,18,20$ & $9,11,37,38,40$ & $\begin{array}{c}80,46 \\
4\end{array}$ \\
\hline
\end{tabular}


Figure 5. Continued

\begin{tabular}{|c|c|c|c|c|}
\hline $\begin{array}{l}\text { Aquatic Ecological } \\
\text { System }\end{array}$ & AES types & Fish SPA & $\begin{array}{c}\text { Macroinvertebrate } \\
\text { groups }\end{array}$ & $\begin{array}{c}\text { Number of } \\
\text { Occurrences }\end{array}$ \\
\hline $\begin{array}{l}\text { Great Plains Prairie } \\
\text { Stream Ecosystem }\end{array}$ & $\mathrm{C005}$ & $2,9,20$ & 9,12 & 86 \\
\hline $\begin{array}{l}\text { Northern Glaciated } \\
\text { Prairie Stream } \\
\text { Ecosystem }\end{array}$ & C006, C008 & $2,4,18,20$ & 9,12 & 67,20 \\
\hline $\begin{array}{l}\text { Great Plains } \\
\text { Intermittent Stream } \\
\text { Ecosystem }\end{array}$ & $\begin{array}{l}\text { D005 } \\
\text { E005 }\end{array}$ & $\begin{array}{l}20,26 \\
\text { None }\end{array}$ & 12 & $\begin{array}{l}94 \\
25\end{array}$ \\
\hline $\begin{array}{l}\text { Northern Glaciated } \\
\text { Intermittent Stream } \\
\text { Ecosystem }\end{array}$ & $\begin{array}{l}\text { D006 } \\
\text { E006 }\end{array}$ & $\begin{array}{l}18,20 \\
\text { None }\end{array}$ & 9,12 & $\begin{array}{c}88 \\
5\end{array}$ \\
\hline $\begin{array}{l}\text { Small Fishless Prairie } \\
\text { Spring Ecosystem }\end{array}$ & S005 & None & 1,12 & 25 \\
\hline Spring Creek Ecosystem & $\begin{array}{l}\text { S001, S002 } \\
\text { S003 }\end{array}$ & 2,7 & $1,4,12,90$ & $\begin{array}{c}5,40 \\
16\end{array}$ \\
\hline $\begin{array}{l}\text { Intermountain } \\
\text { Transitional River } \\
\text { Ecosystem }\end{array}$ & $\begin{array}{c}\text { B001, B002 } \\
\text { B003, B004 } \\
\text { B007 }\end{array}$ & $2,6,7$ & $1,4,90,105$ & $\begin{array}{c}5,7 \\
56,12 \\
17\end{array}$ \\
\hline $\begin{array}{l}\text { Small Foothills River } \\
\text { Ecosystem }\end{array}$ & $\begin{array}{l}\mathrm{C} 001, \mathrm{C} 002 \\
\mathrm{C} 003, \mathrm{C} 004 \\
\mathrm{C} 007, \mathrm{D} 001\end{array}$ & $2,7,20$ & $1,4,105$ & $\begin{array}{c}123,14 \\
55,22 \\
6,3\end{array}$ \\
\hline $\begin{array}{l}\text { Small Pristine Mountain } \\
\text { Stream Ecosystem }\end{array}$ & $\begin{array}{l}\text { D002, D003 } \\
\text { D004, D010 }\end{array}$ & 7,10 & $4,58,90$ & $\begin{array}{l}9,5 \\
80,8\end{array}$ \\
\hline $\begin{array}{l}\text { Alpine Mountain Stream } \\
\text { Ecosystem }\end{array}$ & $\begin{array}{l}\text { E001, E002, } \\
\text { E003, D011 }\end{array}$ & $\begin{array}{l}\text { None, } 7 \mathbf{a}, \\
\quad 10\end{array}$ & 58 & $\begin{array}{l}2,5 \\
2,3\end{array}$ \\
\hline \multicolumn{5}{|c|}{$\begin{array}{l}\text { * Number of Occurrences by AES type in the database, based on one or both biological groups } \\
{ }^{* *} \text { SDM=sand-dwelling mayfly group }\end{array}$} \\
\hline
\end{tabular}




\section{$\underline{\text { Aquatic Ecosystem Descriptions }}$}

\section{Large Valley River Ecosystem}
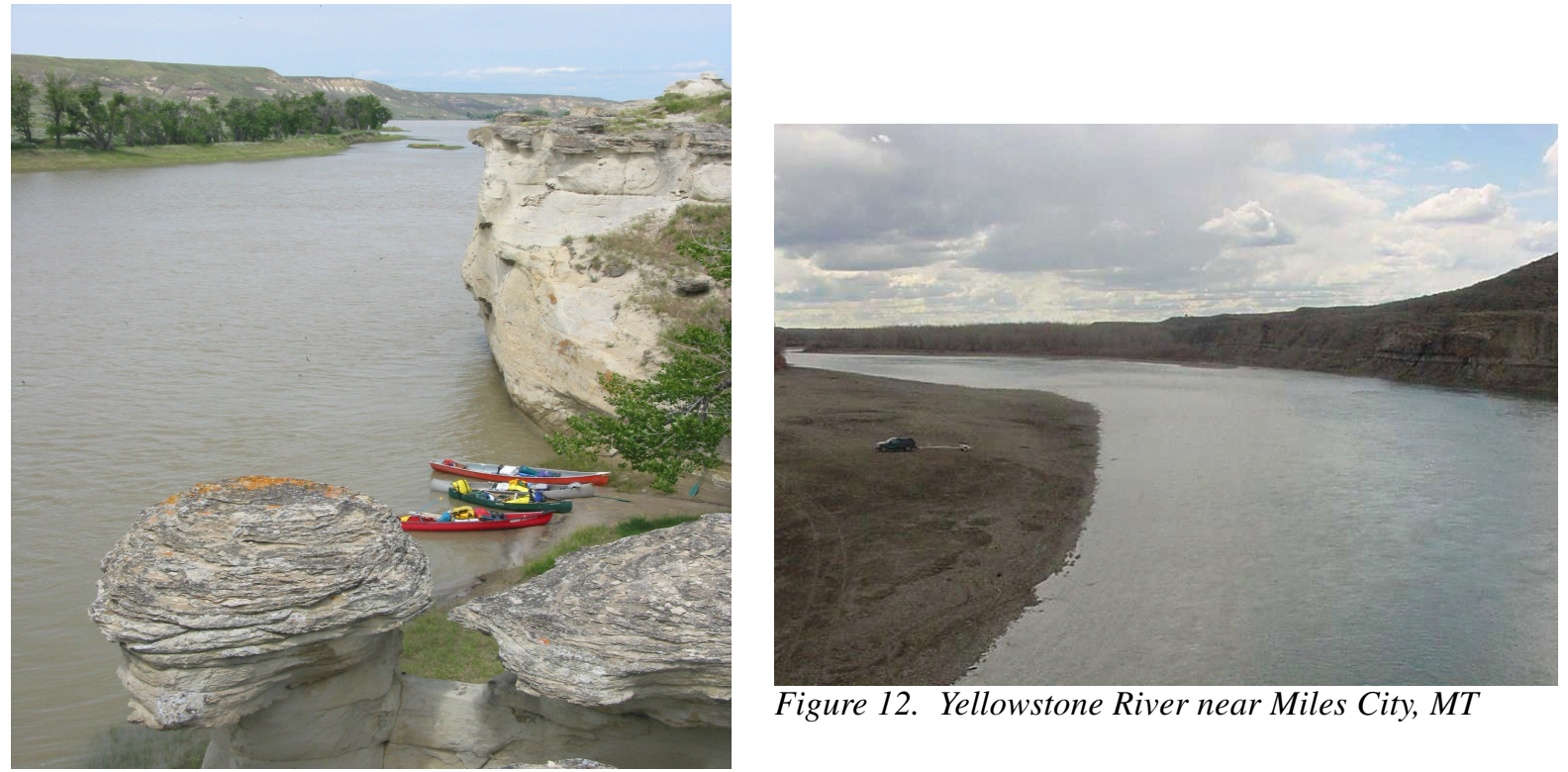

Figure 12. Yellowstone River near Miles City, MT

Figure 11. Missouri River in the Wild and Scenic Area

\section{Aquatic Ecological System Type: A001 and A002}

\section{Community Description}

\section{Summary:}

This ecosystem is found widely throughout the mainstem Missouri River system ( $7^{\text {th }}$ order and larger) of the mid-western and western United States. These large, warm-water rivers have low to moderate gradient with origins in the intermontane basins of Montana. Throughout the range, the river elevation is below $900 \mathrm{~m}$ and characterized by long deep runs and pools with depths $>2 \mathrm{~m}$, numerous mid-stream islands, side channels and interspaced riffles. Substrate characteristics are typically cobble in the riffles, sand and gravel dominated runs and pools, with gravel and/or finer-textured side channels.

\section{Fish Community:}

The members of this community consist of the Large, Medium and Large Mainstem Warmwater River assemblages. The community indicator species are characterized by main channel species, primarily 2 sturgeon species: the shovelnose and the pallid, the freshwater drum, the paddlefish, the burbot, the state species of concern, sturgeon and sicklefin chubs, and the blue sucker. The Missouri mainstem contains one additional species than the Yellowstone, the shortnose gar that has only been recorded downstream from Fort Peck dam. Large Valley River Ecosystem fish communities include the side-channel communities occurring at the margins of the main current or in the quiet side channels; these include, the emerald shiner, channel catfish, mooneye, sauger, flathead chub, carp, white sucker, shorthead redhorse and sand shiner. The shallow riffle habitat areas are inhabited by the longnose sucker, longnose dace, flathead chub with the mountain sucker in the Yellowstone River. 


\section{Macroinvertebrate Community:}

This community consists of members of the Transitional Prairie River, Large Prairie River and Filtering Collector Assemblage in the riffles, with Large River Slow Current and Medium River SideChannel Assemblages in the slow current areas and side channels, and the uncommon sand-dwelling mayfly community group (SDM) in the vast sandbar areas. The community indicator species are characterized by main channel riverine dragonfly species, Stylurus and Ophiogomphus, the mayflies- Neochoroterpes oklahoma, Choroterpes, Camelobatidius, Fallceon quilleri, Acentrella insignificans, Ephoron album, Travarella albertana, the caddisflies- Leucotrichia pictipes, Neotrichia, Psychomyia, Hydropsyche morosa group, Cheumatopsyche, and the mussels- the fatmucket (Lampsilus siliquiodea), black sandshell (Ligumia recta)(Missouri main stem only), and the side-channel mussel, the giant floater (Pyganodon grandis).

\section{Range:}

The Large Valley Warm-Water River Ecosystem type occurs in the Missouri River downstream from Great Falls and below Fort Peck Reservoir and the Yellowstone River downstream from Billings. Additionally, the lower Powder River during spring run-off has occurrences of the large valley river fish assemblage.

\section{Management:}

Large dams and reservoirs have had the most significant negative impact on this community. Dams create barriers to the long distance spawning runs that many fish in this community need, and reservoirs have submerged considerable spawning habitat. Inter-dam reaches (below Great Falls to Fort Peck Reservoir and between Fort Peck and Lake Sacagawea, ND) maintain some of their predevelopment channel morphology, but they are affected by altered water temperatures, unnatural water level fluctuations, and changes in sediment and nutrient transport.

Global Rank: GU

State Rank: S3

\section{Global/State Rank Comments:}

The number of occurrences in the state is fairly well known, and there is regulated angler harvest for one member of this group, the paddlefish. Despite this, the Large Valley River ecosystem is at risk, and contains one of the most endangered fish in the US, the pallid sturgeon (G1S1, USFWS federally endangered). Other fish in this community are Montana Species of Concern: sturgeon chub (S2), sicklefin chub (S1), and blue sucker (S2S3). It also contains the globally rare sand-dwelling mayfly group, which is currently unranked in Montana. The occurrence of numerous threatened, rare and declining species, and consistent threats to the habitats required for spawning and rearing warrants a state rank of an S3. 


\section{Large Prairie River Ecosystem}

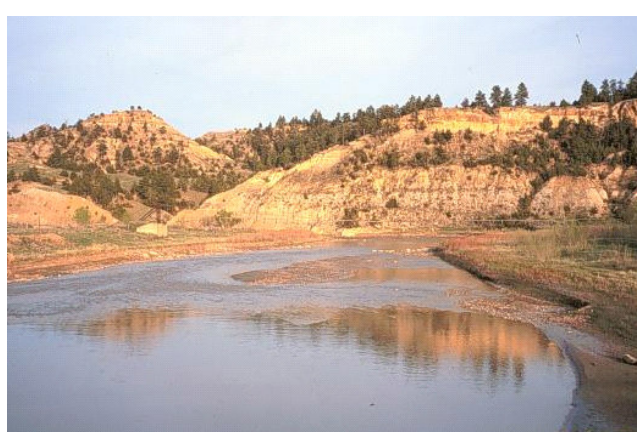

Figure 13. Powder River (A003) riffle habitat near Moorehead, MT

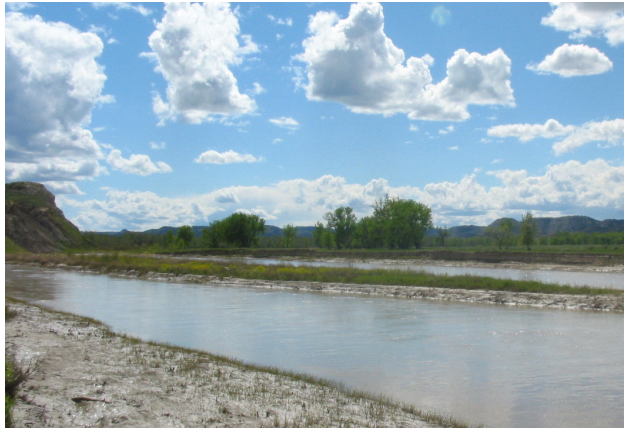

Figure 14. Powder River (A003) gravel run habitat near Broadus, MT

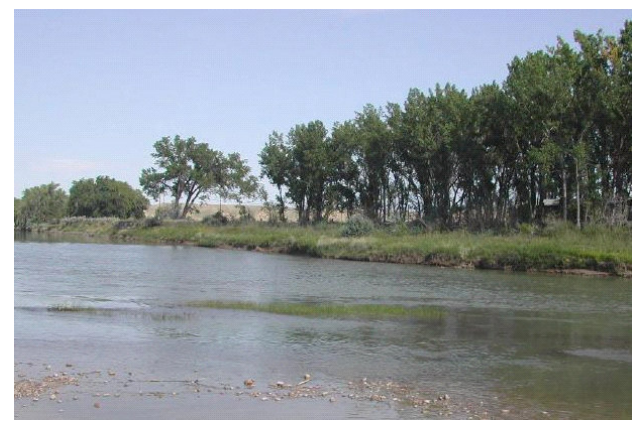

Figure 15. Marias River (A004) riffle

habitat near Loma, MT

\section{Aquatic Ecological System Type: A003 and A004}

\section{Community Description}

\section{Summary:}

This ecosystem consists of the mainstem prairie tributaries to the Missouri and Yellowstone Rivers: the Milk, Marias, Little Missouri, Lower Tongue, Bighorn and Powder Rivers. These large $\left(5^{\text {th }}\right.$ order and larger, $>200$ river miles long, 35m average wetted width), warm-water, rivers have low to moderate gradients with origins in the Rocky Mountain Front of Montana and the Wyoming Bighorn Mountains. These low elevation (below $1000 \mathrm{~m}$ ) rivers are characterized by long deep runs, pools (1$2 \mathrm{~m}$ deep) and interspaced riffles. Substrate characteristics are typically cobble riffles (when present) to sand and gravel dominated runs and pools, with variably textured side channels. Large woody debris and undercut banks in the lower parts of these rivers provide substantial fish habitat. During the spring and early summer, the lower sections of these rivers offer many miles of spawning/ nursery habitat for sauger, walleye, channel catfish, and the characteristic fishes of the Yellowstone and Missouri: the pallid and shovelnose sturgeon and the blue sucker.

\section{Fish Community:}

The members of this community consist of the Large, Medium Warmwater River and the Creek Chub Assemblages. The community indicator species are characterized by mainly native species, the channel catfish, stonecat, mooneye, sauger, flathead chub, plains minnow, sand shiner, white sucker, shorthead redhorse, emerald shiner and some introduced species, including the walleye, northern pike, black bullhead and the spottail shiner (Milk \& Marias Rivers). The shallow riffle habitats are inhabited by the longnose sucker, longnose dace and flathead chub with the mountain sucker included in the Yellowstone drainages. The state threatened sturgeon chub has good 
populations in the gravel run habitats of the Powder River, but not in any other A003 or A004 river of MT.

\section{Macroinvertebrate Community:}

This community consists of members of the Large Prairie River and Filtering Collector Assemblage in the riffles, and the Large River Slow Current and Medium River Side-Channel Assemblages in the slow current and side channels areas, and the special sand-dwelling mayfly community group in the vast sandbar areas of the Powder River. The community indicator species are characterized by main channel riverine dragonfly species, Stylurus and Ophiogomphus, the mayflies- Neochoroterpes oklahoma, Choroterpes, Camelobatidius, Fallceon quilleri, Acentrella insignificans, Ephoron album, Travarella albertana, the caddisflies-Icthythrichia, Psychomyia, Hydropsyche morosa group, Cheumatopsyche, side- channel Hemiptera, the Corixidae, Ambrysus mormon-and the freshwater mussels- the fatmucket (Lampsilus siliquiodea) and the giant floater (Pyganodon grandis).

\section{Range:}

Large Prairie River Ecosystem types occur throughout the Great Plains region of North America within the Missouri River Drainage, with notable rivers such as the Niobrara and Platte (Nebraska), Kansas River (KS), Belle Fourche and James Rivers (ND \& SD). The Montana Glaciated Plains subsection has the lower Milk and Marias River watersheds below Fresno and Tiber Dams, respectively, to their confluence with the Missouri River. Within the Northwestern Great Plains subsection, Montana has the Lower Bighorn River from Hardin to the Yellowstone, the Powder River from the Wyoming border to the Yellowstone and a 100-mile stretch of the Little Missouri from the Wyoming to the ND border. This section of the Little Missouri is more typical of a medium-sized prairie stream, but falls in to the Large Prairie River type further downstream in ND.

\section{Management:}

Large dams and reservoirs have had the most significant negative impact on this community. Fresno and Tiber Dams have substantially altered the downstream hydrology of the Milk and Marias Rivers (Jones 2003). The Milk River becomes increasingly incised below Fresno Dam, and in many segments is not able to access the floodplain. The Milk and Marias Rivers also suffer from degrading channels, where their streambeds are deepening without renewed influx of sediments trapped behind the dams. In the lower Bighorn River, the Yellowtail dam has effectively turned 40 miles of a large prairie river into a trout river, and it only resembles its true nature of a prairie river downstream of Hardin for the last 42 river miles. Anywhere dams occur, the downstream reaches are affected by altered water temperatures, unnatural water level fluctuations, and changes in sediment and nutrient transport. Other threats to these large prairie rivers include water diversions and irrigation for agriculture in the adjacent floodplains.

Global Rank: G4

State Rank: S2

\section{Global/State Rank Comments:}

The number of quality occurrences in the state makes this type rare, and it is at risk across its range (Dodds et al 2004). Within Montana, it contains the sturgeon chub (S2, Species of Concern), and provides suitable spawning/rearing for two other Species of Concern, the sauger (S2) and the blue sucker (S2S3). It also contains the globally rare sand-dwelling mayfly group, which is currently unranked in Montana. The occurrence of many threatened, rare and declining species, and consistent present or future threats (eg. sedimentation, water diversions, coal bed methane) to the habitats required for successful spawning and rearing warrants a state rank of an S2. 


\section{Medium Prairie River Ecosystem}
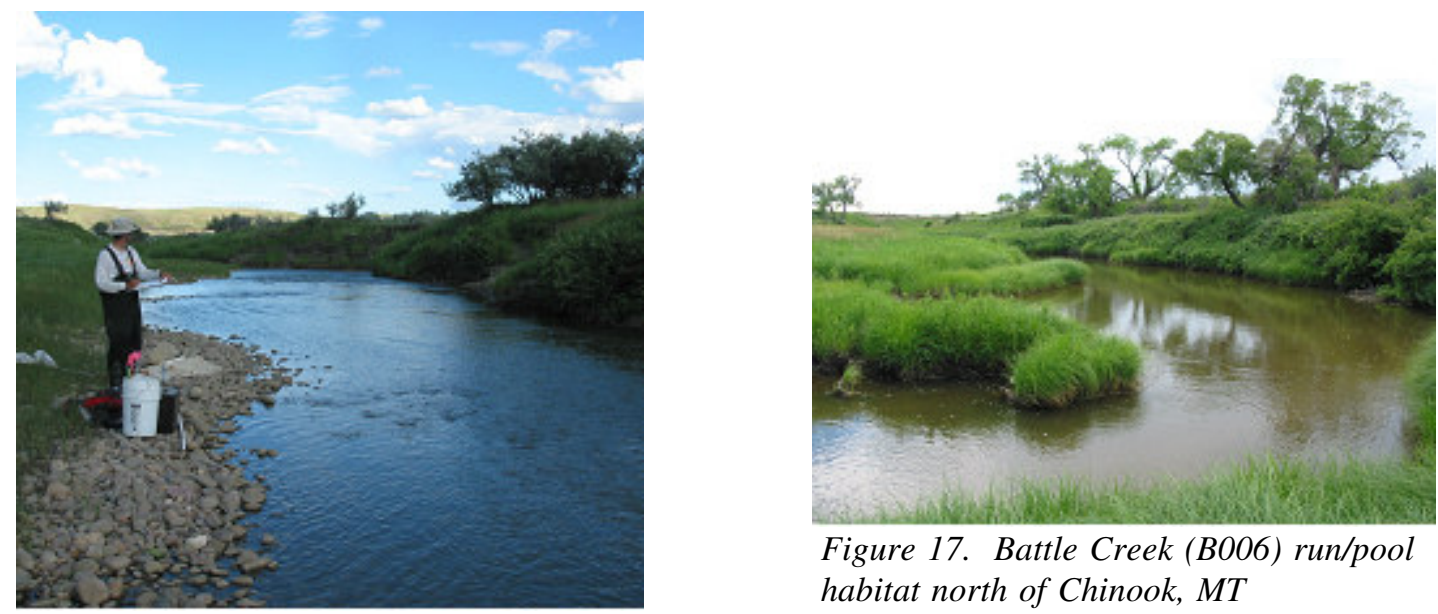

Figure 17. Battle Creek (B006) run/pool

habitat north of Chinook, MT

Figure 16. Frenchman Creek (B006) riffle habitat in the BLM badlands

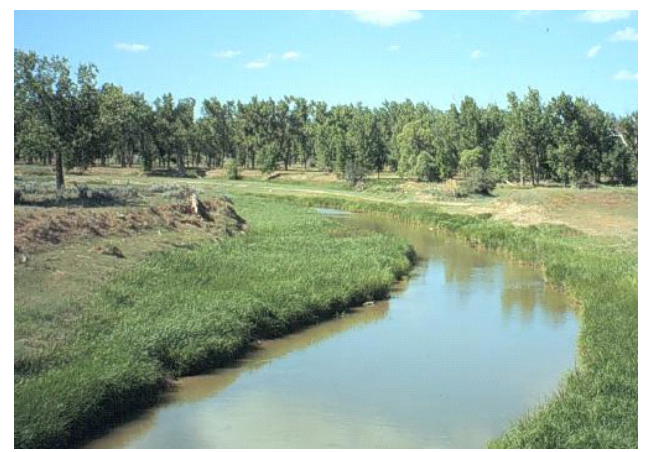

Figure 18. Little Powder River (B005)

run/pool habitat near Broadus, MT

\section{Aquatic Ecological System Type: B005, B006 and B008}

\section{Community Description}

\section{Summary:}

This ecosystem is found widely throughout the Great Plains region of Montana, including many occurrences in the Northern Glaciated and the Northwestern Great Plains. Often these are direct tributaries to the Missouri and Yellowstone rivers, but can have connectivity to other Large Prairie Rivers first, such as the Little Powder River to the Powder or Battle Creek to the Milk River. These are larger $\left(4^{\text {th }}\right.$ and $5^{\text {th }}$ order rivers, $>100$ river miles long, average wetted width- $\left.15 \mathrm{~m}\right)$, perennial warm-water, unconfined valley bottom rivers, but are considered wadable in most reaches by the summer months. In the low to mid-elevation (750-1200m) channels with low gradient, they contain long runs and continuous pools $(1-1.5 \mathrm{~m})$, and in the moderate gradient sections, they contain frequently interspaced (every 20 times wetted width) riffles that maintain connectivity throughout the year, although riffles may be absent in incised and degraded channel sections. Substrate characteristics are typically cobble/pebble riffles (when present) to gravel dominated runs and silted pools. Large woody debris (LWD), deep pools and undercut banks in the lower reaches of these rivers provide substantial fish habitat. During the spring and early summer, the lower sections of these rivers offer spawning and nursery habitat for sauger, walleye, channel catfish and other large warm-water assemblage fishes. 


\section{Fish Community:}

The members of the resident fish community consist of the Large, Medium Warmwater, the Sunfish, the Creek Chub Assemblage and the Core Prairie Stream Assemblage. The community indicator species include fewer species of the Large River assemblage, except at the confluence areas, and are characterized predominately by the native minnow and sucker species of the Medium Warmwater Assemblage: the fathead minnow, lake chub, flathead chub, plains and western silvery minnows, white sucker, shorthead redhorse, and in the deeper runs and pools, the river carpsucker, channel catfish, and the introduced species: the walleye, northern pike, black bullhead, carp and the green sunfish. The riffle areas are inhabited by the longnose dace, flathead chub and if there is large cobbles, the stonecat. The prairie rivers of the Northern Glaciated region (B006 \& B008) are more likely to contain introduced northern pike, black bullhead and yellow perch, while the Northwestern Great Plains (B005) rivers will more likely to have introduced green sunfish, crappie, yellow bullhead and rarely, smallmouth and rock bass (Appendix L \& M).

\section{Macroinvertebrate Community:}

This community consists of members of the Large Prairie River\& Prairie Stream Assemblage and Filtering Collector Assemblage in the riffles, Prairie Stream Assemblage, Large Prairie River Slow Current Assemblage and the Medium Prairie River Side Channel Assemblage. The community indicator species are characterized by main channel riverine dragonfly species, Ophiogomphus, and damselfly genera-Calopteryx and Hetearina, the mayflies- Leucrocuta, Stenonema terminatum, Isonychia, Fallceon quilleri, Ephoron album, Tricorythodes and Caenis latipennis; the caddisflies- Hydropsyche morosa group, Cheumatopsyche and Polycentropus, numerous Corixidae and the mussels- the fatmucket (Lampsilus siliquiodea), and the side-channel mussel, the giant floater (Pyganodon grandis).

\section{Range:}

The Medium Prairie River Community type occurs throughout the Great Plains region of North America within the Missouri River Drainages. In the Montana Glaciated Plains subsection, we have the Redwater River, Frenchman, Rock, Battle, Lodge, Poplar, Wolf, Big Muddy and Beaver Creeks, as examples, and in the Northwestern Great Plains, the Tongue, O' Fallon, Mizpah, Pumpkin, Rosebud, Little Beaver and Beaver Creeks.

\section{Management:}

Small dams, water diversions, stock ponds and introduced gamefish species have had the most significant negative impact on this community (Winston et al. 1991). Anywhere dams occur, the downstream reaches are affected by altered water temperatures, introduced fish, unnatural water level fluctuations, and changes in sediment and nutrient transport.

\section{Global Rank: GU}

State Rank: S4

\section{Global/State Rank Comments:}

Good quality occurrences in Montana are common, but the native fish community suffers from fish introductions and homogenization. This community contains the creek chub (a potential SOC) in the far eastern Montana drainages. Within the Northern Glaciated region of Montana, it contains the atrisk pearl dace (S2, Species of Concern), and three Potential Species of Concern: the Iowa darter, plains minnow and stonecat. The occurrence of at-risk or potentially declining fish and macroinvertebrate species may cause long-term concerns for this ecosystem and indicate a rank of S4. 


\section{Great Plains Prairie Stream Ecosystem}

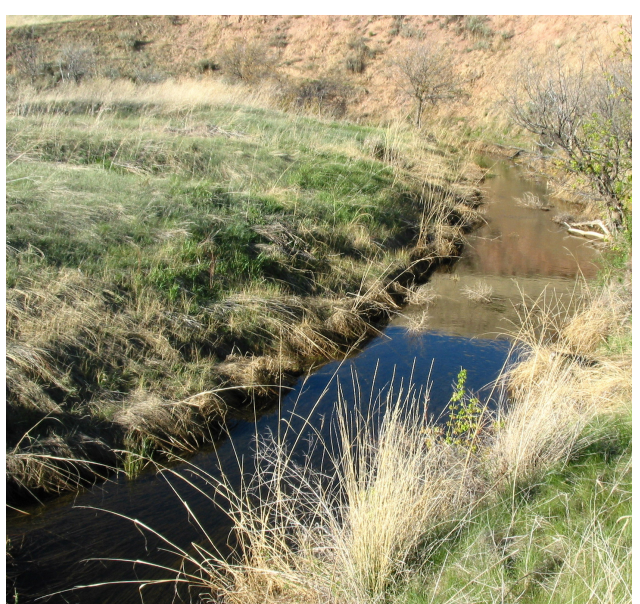

Figure 19. Otter Creek (COO5) run/pool habitat near Ashland, MT

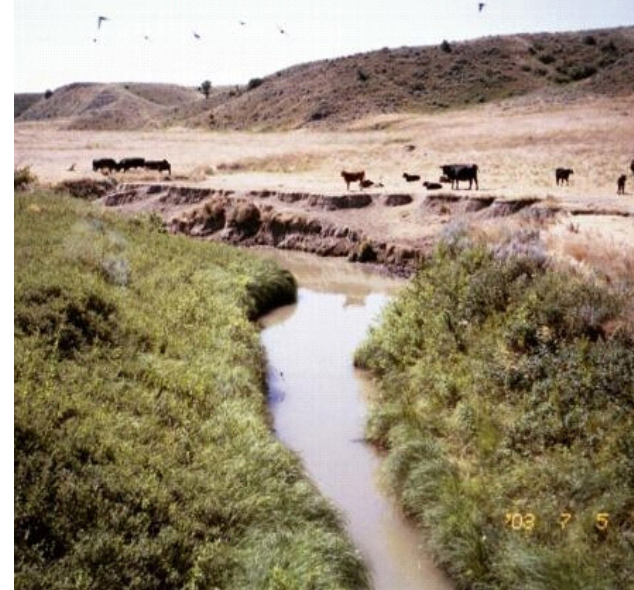

Figure 20. Rotten Grass Creek (C005) moderately degraded Great Plains stream

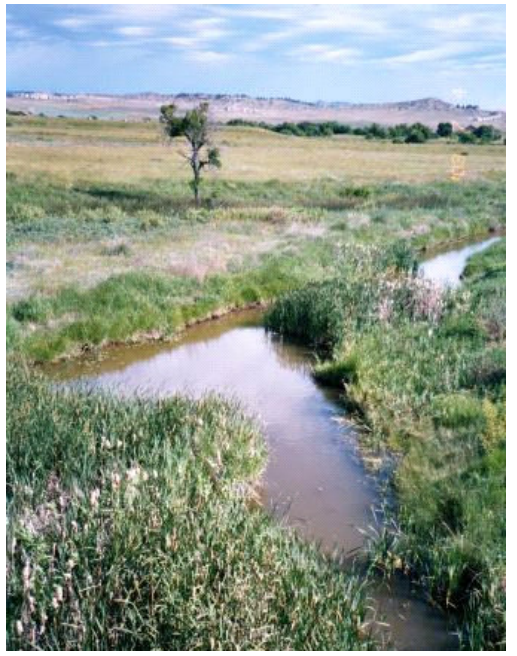

Figure 21. Hanging Woman Creek (C005) (small Great Plains meandering stream with vegetated pools)

\section{Aquatic Ecological System Type: C005}

\section{Community Description}

\section{Summary:}

This ecosystem is found throughout the drainages of the sedimentary Great Plains and Powder River Basin regions of Montana. Habitats are small to medium $\left(3^{\text {rd }}-4^{4^{\text {th }}}\right.$ order, $<100$ river miles long, average wetted width-5m), perennial warm-water streams, or the upstream reaches of Medium Prairie Rivers. In the low elevation (750-1000m) areas, these are low gradient, meandering streams with a typical stream morphology consisting of long runs, continuous standing pools (1-1.5 $\mathrm{m}$ depth) (see Figure 19,20), and in the moderate gradient sections, they may contain infrequently spaced (40-50 times wetted width) riffles that may maintain wetted connectivity throughout the year. Riffle habitats may be absent in incised and degraded channel sections (see Figure 21). Substrate characteristics are typically cobble/pebble riffles (when present) to pebble/gravel silted runs and deeply silted pools. 
Side channel vegetation, undercut banks and woody debris in the lower reaches of these streams provide the most diverse fish habitat.

\section{Fish Community:}

The members of the resident fish community are dominated by the Core Prairie Stream Assemblage and occasionally members of the Medium Warmwater and Creek Chub Assemblages. A fairly clear Great Plains stream in far-eastern MT with weedy pools, may contain the brook stickleback, northern redbelly dace or the brassy minnow, but for the typical turbid Great plains stream, the community indicator species include the fathead minnow, lake chub, flathead chub, white sucker, creek chub, and the introduced species: the black bullhead, carp and the green sunfish. If the stream has gravel substrate in the riffle areas there will likely be longnose dace and if there are large cobbles or LWD, the stonecat as well. A severely impaired C005 community will be dominated by green sunfish (plus other members of the Sunfish assemblage), plains killifish, black bullhead and fathead minnows.

\section{Macroinvertebrate Community:}

This community consists of members of the Large Prairie River and Prairie Stream Assemblages in the riffle/run habitats with Large River Slow Current Assemblage in the slow current areas, side channels and vegetated pools. The community indicator species are characterized by the crustaceans, Hyalella and Gammarus, damselfly genera, Coenagrion/Enallagma sp. Enallagma civile, many genera and species of the water boatman (Corixidae): Sigara alternate, Sigara grosslineata, Trichocorixa, Trichocorixa nais, and Corisella. The snails- Physella, Gyraulus, Stagnicola; the mayflies-Caenis and Callibaetis, and in the cobble riffles-the caddisflies-Hydropsyche morosa group, Cheumatopsyche, and riffle beetles-Dubiraphia and Microcylloepus, the mussel, the giant floater (Pyganodon grandis) is common in the small Northern glaciated streams, but is rarely encountered in the Powder River Basin C class streams.

\section{Range:}

The Small Great Plains Prairie Stream Community occurs throughout the Great Plains region of North America within the Missouri River Drainage. In the Northwestern Great Plains of Montana, we have a diversity of this community type existing in streams, such as the Otter, Sarpy, Armells, Beauvais, Big \& Little Porcupine, Cabin, Cedar, Sweeny, Sandstone and Hanging Woman Creeks.

\section{Management:}

Small dams, water diversions, stock ponds and introduced gamefish species have had the most significant negative impact on this community (Winston et al. 1991). Other threats include cattle intrusions to the riparian areas causing bank erosion and subsequent sedimentation and siltation. Anywhere dams occur, even small stock pond earthen dams; the downstream reaches are affected by altered water temperatures, unnatural water level fluctuations, and changes in sediment and nutrient transport.

\section{Global Rank: G5}

\section{State Rank: S5}

\section{Global/State Rank Comments:}

The number of quality occurrences in the state is common, but this native community does suffer from fish introductions and community homogenization. This community contains the creek chub, plains minnow and Iowa darter in the far eastern MT drainages, which are potential species of concern for Montana, and important indicator species for this community. 


\section{Northern Glaciated Prairie Stream Ecosystem}

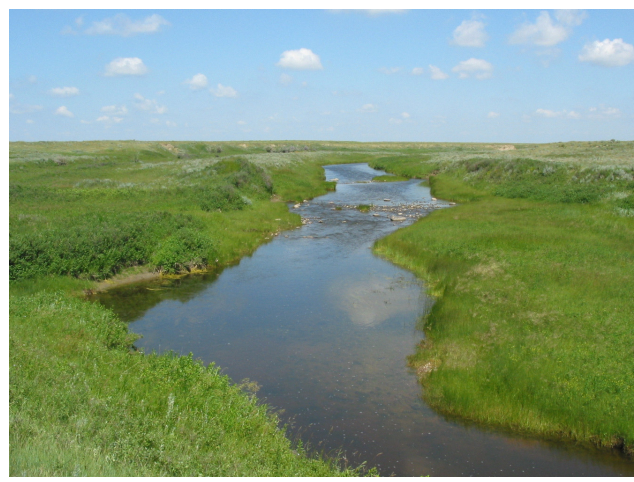

Figure 22. Battle Creek riffle/run upstream reach (C006) of a small Northern Glaciated prairie stream

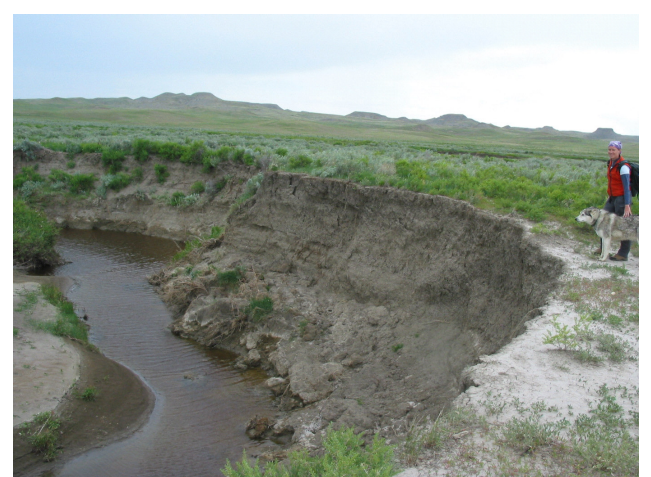

Figure 23. Cottonwood Creek (C006) severely incised Northern Glaciated prairie stream

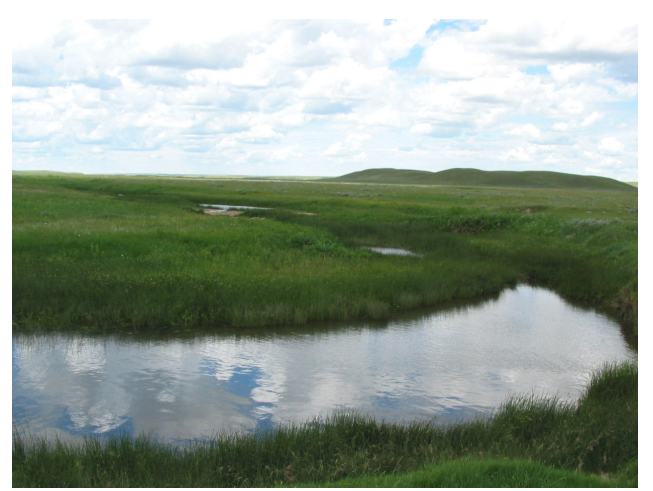

Figure 24. Whitewater Creek reference condition (C006) small Northern

Glaciated prairie stream

\section{Aquatic Ecological System Type:} C006, $\mathrm{C008}$

\section{Community Description}

\section{Summary:}

This ecosystem is distributed widely throughout the Northern Montana and Northwestern Glaciated Plains ecoregions. Habitats are small to medium $\left(3^{\text {rd }}-4^{\text {th }}\right.$ order, $30-100$ river miles long, average wetted width-6m), perennial cool/warm-water streams. In low elevation $(800-1000 \mathrm{~m})$ areas, these are meandering streams with long runs, and wide continuous pools $(0.5-1.5 \mathrm{~m}$ in depth) (see Figure 24 ), connected by narrow (average wetted width $\sim 2 \mathrm{~m}$ ) infrequently spaced ( $\sim 0$ times wetted width) riffles that may maintain connectivity throughout the year (see Figure 22), although riffles may be absent in incised and degraded channel sections (see Figure 23). Substrate characteristics are typically cobble/pebble riffles (when present) to pebble/gravel runs and deeply silted pools. Side channel vegetation, undercut banks and vegetated, deep pools provide the most diverse fish habitat. Woody debris is largely absent from the typical C006 and C008 stream.

\section{Fish Community:}

The members of the resident fish community are dominated by the Core Prairie Stream, the Brook Stickleback Assemblage and in clear, non-degraded streams, members of the Northern Redbelly Dace Assemblage. Without aquatic macrophytes in the pools or runs, the occurrence of the brook stickleback or northern redbelly dace will be rare. A typical Northern Glaciated Prairie Stream 
Community will have fathead minnows, lake chubs (not as common), brook sticklebacks, northern redbelly, pearl dace, and brassy minnows in the vegetated pools and white suckers, longnose dace and potentially the plains minnows, stonecat and Iowa darters in the cobble/pebble riffle and gravelly run sections. Unfortunately, the northern pike has been widely introduced as a gamefish in the Northern regions of Montana, and small prairie streams containing reproducing populations of these predators will quickly lose their water column species, such as northern redbelly dace, Pearl dace, Iowa darters, plains and brassy minnows. A fish community with the introduced pike will usually degrade to a native community of fathead minnows and white suckers.

\section{Macroinvertebrate Community:}

This community consists of members of the Large Prairie River Assemblage and Prairie Stream Assemblages in the riffles, and the Medium River Side-Channel and Prairie Pool Assemblages in the slow current areas, side channels and vegetated pools. The community indicator species are characterized by the crustaceans, Hyalella and Gammarus, damselfly genera, Coenagrion/ Enallagma sp. Enallagma civile, many genera and species of the water boatman (Corixidae): Sigara grosslineata, Trichocorixa, Trichocorixa nais, and Corisella. The snails- Physella, Gyraulus, Stagnicola; the mayflies-Caenis and Callibaetis, and in the cobble riffles-the caddisfliesHydropsyche morosa group, Cheumatopsyche, and riffle beetles-Dubiraphia and

Microcylloepus, the mussel, the giant floater (Pyganodon grandis) can be found in the gravel to silted side-channels, since two of it's host fish species are members of the Brook Stickleback Assemblage.

\section{Range:}

The Small Northern Glaciated Prairie Stream Community type occurs throughout the north-central glaciated region of North America within the Missouri and Mississippi River Drainages. Within Montana, this community exists in a multitude of streams such as, Woody Island Coulee, upper Battle, upper Whitewater, Snake and People's Creeks, West Fork Poplar River, Stinky, Big and Little Warm, Assiniboine, Willow, Little Cottonwood, Porcupine and Little Porcupine Creek.

\section{Management:}

Small stock ponds, dams, water diversions and introduced gamefish species have had the most significant negative impact on this community. Anywhere dams occur, the downstream reaches are affected by altered water temperatures, introduced fish, unnatural water level fluctuations, and changes in sediment and nutrient transport. Other threats include cattle intrusions with the resulting riparian degradation and bank trampling.

\section{Global Rank: G5}

State Rank: S3

\section{Global/State Rank Comments:}

The number of quality occurrences in the state is unknown, but it probably is present in only 50\% of it's original streams, mainly due to game fish introductions, especially Northern pike. The unimpaired stream community contains the northern redbelly dace, and the Montana SOC northern redbelly/ finescale hybrid dace (S3), the pearl dace (S2), and the potential species of concern, the Iowa Darter and brassy minnow. The occurrence of numerous rare, threatened or declining fish and macroinvertebrate species, and consistent (e.g. water diversions, northern pike populations) or future threats (natural gas wells) warrants a state rank of an S3. 


\section{Great Plains Intermittent Stream Ecosystem}

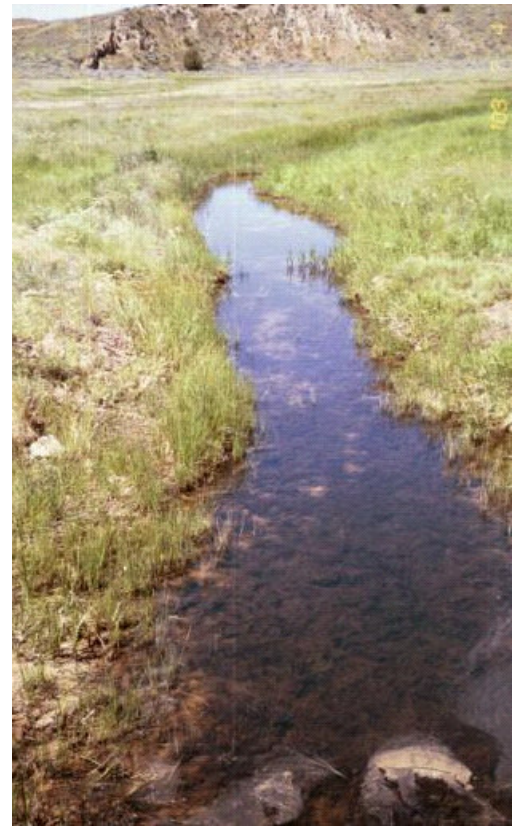

Figure 25. Deer Creek (D005) an intermittent Great Plains stream near Decker, $M T$

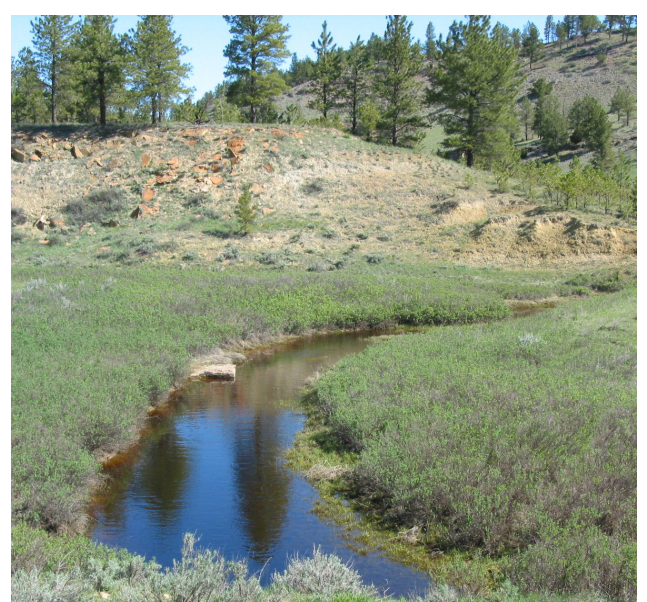

Figure 26. Tooley Creek (E005) a reference condition Great Plains intermittent fishless pool near Otter, MT

\section{Aquatic Ecological System Types: D005 and E005}

\section{Community Description}

\section{Summary:}

This community is widely distributed throughout the coulees, small streams ( $\left(1^{\text {st }}\right.$ to $3^{\text {rd }}$ order) and headwaters of small or medium prairie streams (B005, C005) within the Northwestern Great Plains region of the Missouri river drainages. These small, warm-water, low to moderate gradient and elevation (900-1200m) intermittent streams have origins in the Northwestern Great Plains and the Powder River Basin subsection. Stream sections in the moderate gradient reaches (riffles/runs) are the first to lose flowing water connectedness to become interrupted pools (D005). Once these systems lose their connectivity to the fish recruitment pools of downstream reaches (this may be due to climatic factors over many years such as drought), they become fishless isolated pools (E005). Throughout the range, these clear to turbid streams are characterized by short to long $(\sim 2-25 \mathrm{~m})$ pools that are sometimes vegetated, with silted gravel to cobble substrates. The fishless pool community type provides substantial amphibian breeding and rearing habitat in otherwise harsh, dry upland conditions, so Bufo spp. (toads) and Rana pipiens (Northern Leopard Frogs) tadpoles and adults are usually present.

\section{Fish Community:}

The members of the resident fish community are dominated by the Lake Chub or the Core Prairie Stream Assemblage ( 2 potential members). If connectivity to downstream reaches exists on an annual basis, lake chubs or fathead minnows will be the dominant species, with the occasional pioneering white sucker. If there is vegetation in the pools, the Brook Stickleback may be present, but oftentimes it is just the single fish species dominated pool. The only introduced fish species reported from a D005 stream was the black bullhead. 


\section{Macroinvertebrate Community:}

This community consists of members of the Prairie Stream and Pool Assemblages, occurring in the cobbles and vegetative pool areas, respectively. The reference community indicator species are characterized by the crustaceans, Hyalella and Gammarus, damselfly genera, Coenagrion/ Enallagma sp. Enallagma civile, Ishnura, many genera and species of the water boatman (Corixidae): Sigara alternate, Sigara grosslineata, Trichocorixa, Trichocorixa nais, and Corisella, the snails- Physella, Gyraulus, Stagnicola; the mayflies- Caenis and Callibaetis, and beetles- Oreodytes, Laccophilus, Hydroporus and Hygrotus. As the complexity of the pool habitat decreases, you will lose the clinger habitat species, such as the damselflies and many of the water boatman taxa. The truly intermittent fishless pools (E005) may be only in existence for a few months. If these pools are dry for more than a year and than rehydrate, many invertebrates with resting egg stages dominate the pools, including the crustaceans: Ostracoda, Cladocera, Copepoda, the fairy shrimp-Branchinecta, Eubranchipus, the clam shrimp-Caenestheriella, and the tadpole shrimp-Lepidurus.

\section{Range:}

The Great Plains Intermittent Stream Community type occurs throughout the Northwestern Great Plains region of North America within the Missouri and Mississippi River Drainages. Within Montana, this community exists in a multitude of streams and coulees, with a few notable examples, Ranch, Rough, Deer, Tooley (Figures 25 \& 26), Little Bear, Little Pumpkin, Buffalo, Home and Taylor Creeks.

\section{Management:}

Small stock ponds, dams, and cattle intrusions have had the most significant negative impact on this community. Anywhere stock ponds and dams occur, the downstream reaches are affected by altered water temperatures and flow, and changes in sediment and nutrient transport (Winston et al. 1991). The spring flows backed up behind stock pond dams could have potentially filled numerous E005 pools, and possibly connected these pools for a brief period to downstream fish populations for recolonization. Therefore, unless there is sufficient outflow, streams and coulees below stock ponds usually do not develop this community type. Another threat to this community includes cattle intrusions, which cause trampling of stream banks with the subsequent siltation and nutrient inputs (cow pies) into the pools. This siltation and nutrient loading may eliminate aquatic macrophytes and cause blue-green algae blooms. This native community, as well as others downstream, suffers from cattle damage to the riparian areas of these pools and therefore, riparian areas adjacent to streams should be given priority protection for this community and other attributes associated an intact riparian zone.

Global Rank: G5

State Rank: S5

\section{Global/State Rank Comments:}

The number of quality occurrences in the state is unknown, but probably numerous, although this is a difficult type to quantify given the past years of drought in the state. Intermittent pools containing the Ostracoda group should be inventoried for unique crustaceans, such as fairy or tadpole shrimp. 


\section{Northern Glaciated Intermittent Stream Ecosystem}

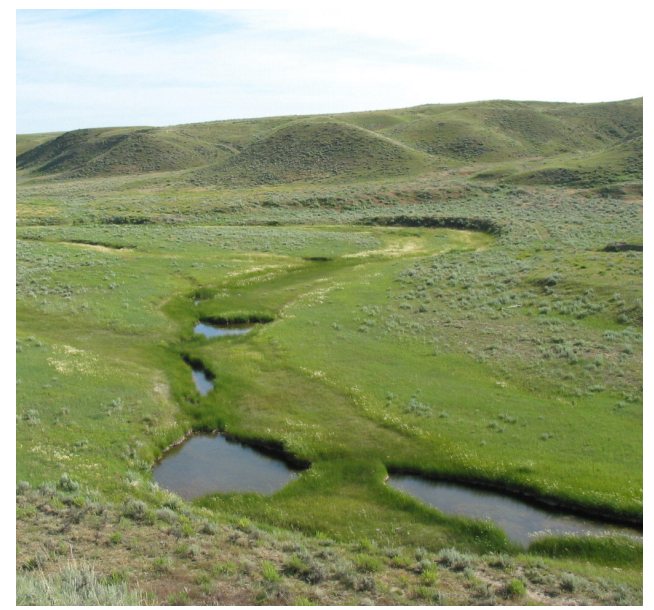

Figure 27. Little Sandy Creek (D006) a reference condition Northern Glaciated intermittent prairie stream

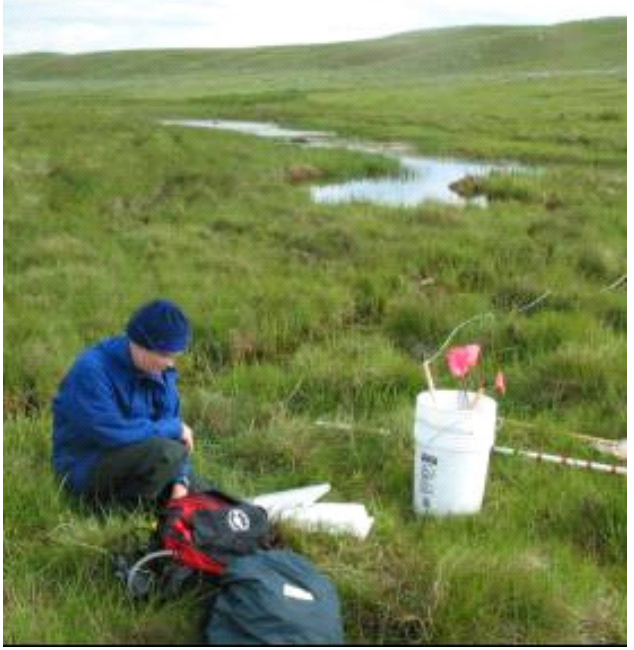

Figure 28. Murray Coulee (D006) slightly impaired Northern Glaciated intermittent prairie stream

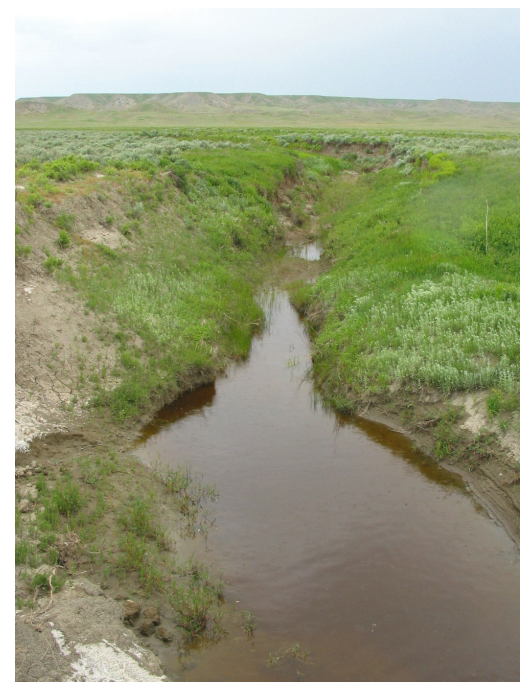

Figure 29. Cowen Coulee (E006) impaired Northern Glaciated fishless pool

\section{Aquatic Ecological System Types: D006 and E006}

\section{Community Description}

\section{Summary:}

This ecosystem is found widely throughout the coulees, small streams ( $1^{\text {st }}$ to $3^{\text {rd }}$ order, average wetted width-3m) and headwaters of small to medium prairie streams (B006, C006, C008) within the Northern Glaciated ecoregion of the Missouri river drainages. These small, cool to warm-water, low gradient and elevation (900-1200m) streams have origins in the alluvium and sedimentary geology of the Northern and Northwestern glaciated ecological sections, and the Missouri Choteau. Throughout 
their range these clear (more common) to turbid streams are characterized by long pools that are usually vegetated, separated from each other by narrowed riffle areas that are usually dry by earlysummer forming isolated pools or the "string of pearls" (see Figure 27). Once these systems lose their connectivity to the fish recruitment pools of downstream reaches (may be due to climatic factors such as drought), or that never had fish potential, they become the fishless isolated pool ecosystem type (E006) (Figure 29). Substrate characteristics can be gravel to cobbles in the shallow pools to silted gravel deeper pools with rooted vegetation. These pools, on average, remain filled longer and are cooler and wider than their Great Plains counterparts.

\section{Fish Community:}

The members of the resident fish community are dominated by Brook Stickleback Assemblage and the Core Prairie Stream Assemblage; and in the largest clear, non-degraded pools, members of the Northern Redbelly Dace Assemblage may persist. A reference-condition Northern Glaciated Intermittent Stream community will have fathead minnows, brook sticklebacks, lake chubs (not as common), brassy minnows and northern redbelly dace in order of dominance. Without aquatic macrophytes in the pools, the occurrence of the brook stickleback or northern redbelly dace will be rare. Although, more typically this community will be co-dominated by fathead minnows and brook sticklebacks only, and in truly degraded or non-vegetated systems, just fathead minnows. The E006 ecological system type will be fishless.

\section{Macroinvertebrate Community:}

This community consists of members of the Prairie Stream and Pool Assemblages, occurring in the cobbles and in the vegetative pool areas respectively. The reference community indicator species are characterized by the crustaceans, Hyalella and Gammarus, damselfly genera, Coenagrion/ Enallagma sp. Enallagma civile, Ishnura, many genera and species of the water boatman (Corixidae): Sigara alternate, Sigara grosslineata, Trichocorixa, Trichocorixa nais, and Corisella, the snails- Physella, Gyraulus, Stagnicola; the mayflies- Caenis and Callibaetis, and beetles-Haliplus, Oreodytes, Laccophilus, Hydroporus and Hygrotus. As the complexity of the pool habitat decreases, you will lose the clinger habitat species, such as the damselflies and many of the water boatman taxa. The truly intermittent fishless pool ecosystems (E005) may only exist for a few months. If these pools are dry for more than a year and than rehydrate, many invertebrates with resting egg stages dominate the pools, including the crustaceans: Ostracoda, Cladocera, Copepoda, the fairy shrimp-Branchinecta, Eubranchipus, the clam shrimp-Caenestheriella, and the tadpole shrimp-Lepidurus.

\section{Range:}

The Northern Glaciated Intermittent Stream Ecosystem occurs throughout the glaciated great plains regions of northern North America within the Missouri and Mississippi River Drainages. Within Montana, this community exists in a multitude of streams and coulees mostly situated north of the Missouri River, with a few examples included here: Little Sandy Creek, Murray Coulee, Cowen Coulee (Figures 27, 28 \& 29) Rattlesnake, Little Sage, Coberg, E. Fork Battle, Black, Snow and Hell Coulee, Bitter, Buggy, and E.F. Porcupine Creeks.

Global Rank: G5

State Rank: S5

\section{Global/State Rank Comments:}

The number of quality occurrences in the state is unknown, but probably fairly common. Although this is a difficult community type to quantify given the past years of drought in the state and the tenuous nature of this aquatic system. 


\section{Northwestern Great Plains Perennial Spring Ecosystem}

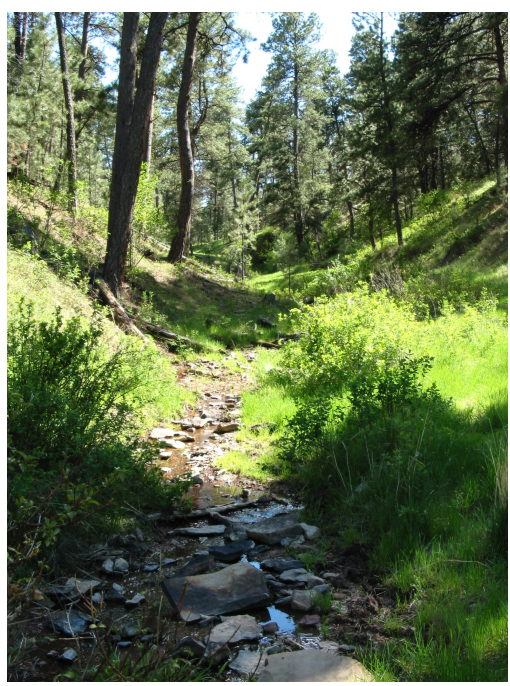

Figure 30. Cow Creek (S005)

reference spring example within the Custer National Forest

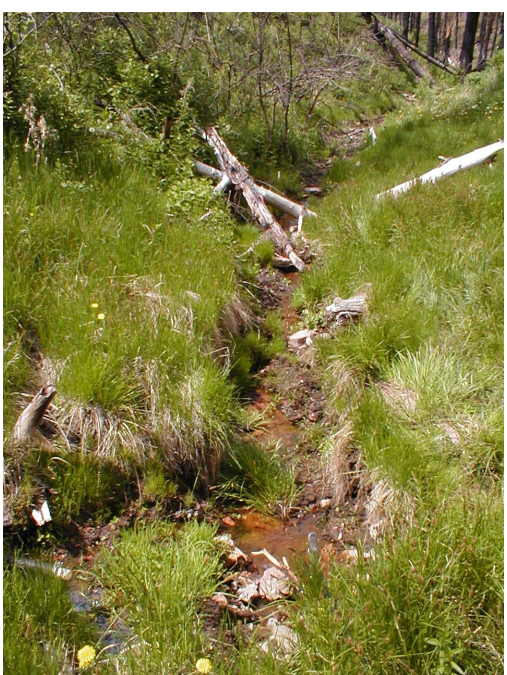

Figure 31. Charcoal Spring (S005) a slightly impaired example within the Custer National Forest

\section{Aquatic Ecological System Type: S005}

\section{Community Description}

\section{Summary:}

This ecosystem is found in the moderate elevation $(1000-1600 \mathrm{~m})$, upland hill areas of the Northwestern Great Plains. It occurs in small $(0.2-2 \mathrm{~m})$ perennial fishless, headwater springs with low to moderate gradient flowing through sedimentary geology. Benthic habitats are typically long riffle/ run reaches dominated by shale cobbles and gravel with some woody debris (Figures $30 \& 31$ ).

\section{Environment:}

Throughout its Montana range, it occurs in seeps and springs within the Custer National Forest, Wolf Mountains and the higher elevation Ponderosa pine forests of the Powder River Basin. Surface topography usually has a moderate gradient or sometimes undulating or hummocky. Disturbance by cattle is widespread, as these springs often represent the only water source in the uplands.

\section{Fish Community:}

This is a fishless system.

\section{Macroinvertebrate Community:}

The reference condition ecological system (S005) indicator macroinvertebrates include the midges Odontomesa, Radotanypus, Heleniella, Pseudodiamesa, diptera - Tipula, Dicranota, Ormosia, Pedicia, the snails - Hydrobiidae and Physa; the Mayfly- Baetis tricaudatus, the caddisflyHesperophylax designatus, the water mite and leech-Hydrachna and Glossophona complanata, the Beetles-Oreodytes, Optioservus and Hydroporus, and the damselfly larva- Argia. Sediment impaired and cattle degraded springs will quickly lose the mayfly, caddisfly, and dipteran species (above), and form a community dominated by tolerant midges, biting dipteran larvae (Ceratopogonidae) and air breathing beetles. 


\section{Range:}

The Northwestern Great Plains Perennial Spring Community type has been collected in the Custer National Forest, Wolf Mountains and the higher elevation Ponderosa pine forests of the Powder River Basin.

\section{Management:}

Grazing and livestock use around these springs should be limited to a stock tank; immediate spring areas should be fenced to avoid intrusions. Soils adjacent to the springs are often waterlogged and are easily trampled and hummocked by livestock, causing severe streambed degradation, sedimentation and siltation downstream.

Global Rank: GU

State Rank: S4

\section{Global Rank Comments:}

The number of occurrences is unknown. In Montana, this ecosystem is reported from 25 site visits within the Custer National Forest Ashland District, but only three of these sites contained a quality, fully functional S005 community (Stagliano 2004). In a similar ecological type, the caddisfly, Hesperophylax designatus was also found to be an indicator species of perennial springs in the Glass Mountains of the Great Basin (UT) in a 1994 survey (Myers 1995). Therefore, this ecosystem may be widespread, but because of the limited occurrence of high integrity sites in Montana, should probably be evaluated for long-term monitoring, and restoration of degraded sites. 


\section{Montana Spring Creek Ecosystem}

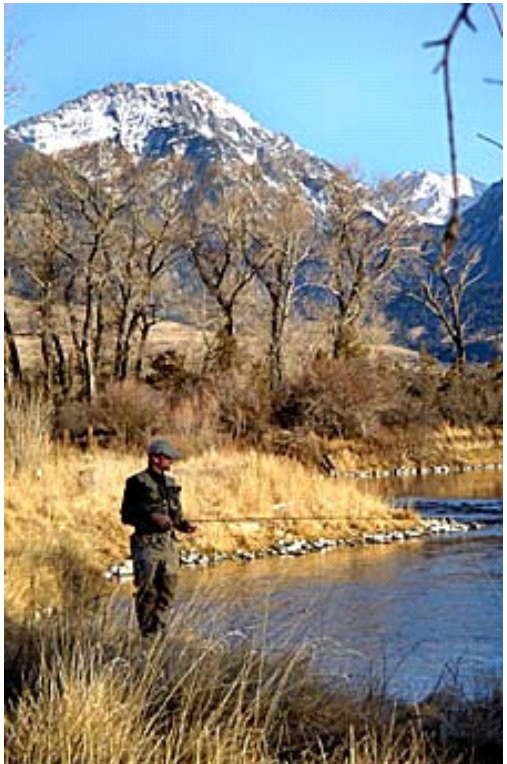

Figure 32. Armstrong Spring

Creek (S002) within the Paradise

Valley. Photo taken by:

Yellowstone Flyfishers, Inc.

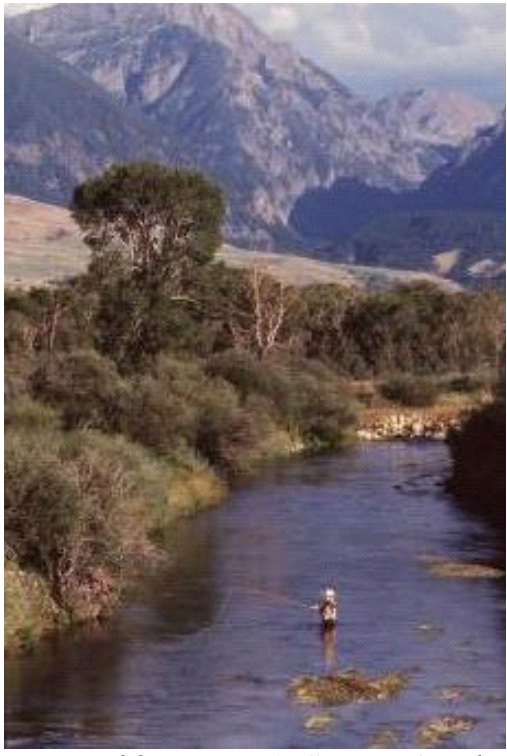

Figure 33. DePuy's Spring Creek (S002) within the Paradise Valley. Photo taken by: DePuys Spring Creek, $L L C$

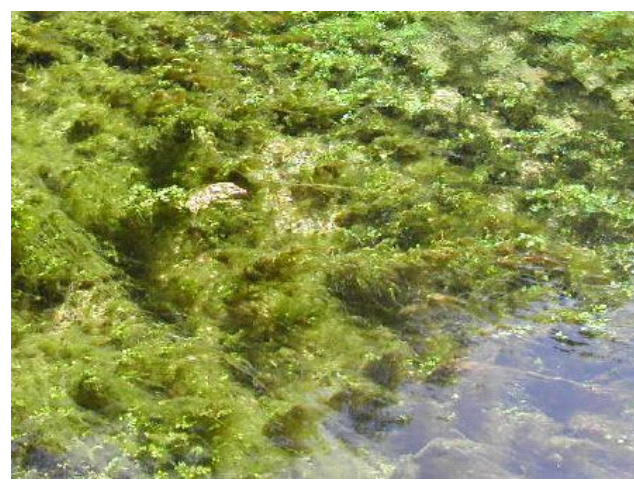

Figure 34. Big Spring Creek aquatic

vegetation (SO02) near Lewistown, MT

\section{Aquatic Ecological System Type: S001, S002, S003}

\section{Community Description}

\section{Summary:}

This ecosystem is found in valleys or upland foothill areas of the Montana Foothills and Valleys Ecoregion with moderate elevation $(1200-2000 \mathrm{~m})$, or on the valley floors adjacent to mountain ranges as they decrease in elevation \& gradient (see Figure 33). These small to medium (average wetted width-2-15m, average summer temperature: $<15^{\circ} \mathrm{C}$ ) rivers have moderated permanent flow with strong seasonal variability depending on aquifer levels. Waters are mineral-rich and circumneutral to alkaline with $\mathrm{pH}$ of 7.0-8.2; clarity is often high. These factors contribute to lush growth of submerged aquatic vegetation, which may include watercress, Potamogeton spp., and Myriophyllum spp. (see Figure 34). These streams represent groundwater input surface flows, therefore, they do not experience flooding or drastic temperature shifts and have flow that is more constant. The 
substrate of these streams is usually cobble riffles, gravel/sand runs and pools, with extensive beds of aquatic vegetation (Figure 34), and unless they are degraded by cattle, flow silt-free and clear.

\section{Fish Community:}

The members of this community consist of species from the Coolwater Transitional Community, and the Traditional Trout Stream Assemblage. The community would typically be characterized by mainly native species, the Westslope cutthroat, the mottled sculpin, longnose dace, mountain whitefish, with the Yellowstone cutthroat trout and mountain sucker in the Yellowstone drainages. However, the introduced species of the stocked trout assemblage, the brook, brown and rainbow trout, tend to dominate and become the focal species of these systems.

\section{Macroinvertebrate Community:}

Studies show that Spring Creeks have abundant macroinvertebrate populations, but a relatively limited diversity. This unique low-diversity, community consists of a combination of members from the Medium Cool-Water Transitional, the Traditional Trout Stream, and the Foothills Transitional Assemblages. The community is dominated by the mayflies, Tricorythodes, Ephemerella spp. (usually Ephemerella inermis and E. infrequens), the amphipod crustacean- Gammarus, and many Chironomidae. Other community indicator species include: Baetis tricaudatus, the caddisfly species, Hydropsysche, Amiocentrus aspilis, Cheumatopsyche, Brachycentrus occidentalis, the beetleOptioservus sp. and snails- Gyraulus, Physella, Stagnicola and Hydrobiidae.

\section{Range:}

The Spring Creek Ecosystem type has been identified in the foothills of many Montana drainages, particularly some of the more famous trout fishing spots: Armstrong's, Depuy's, Nelson's Spring Creeks of the Yellowstone, and Thompson, Ben Hart (trib. to the E. Gallatin), O'Dell, Warm Spring and Big Spring Creek of the Missouri drainages.

\section{Management:}

Grazing and livestock use around the riparian areas is common and can have strong local effects resulting in sedimentation and stream widening/shallowing. Grazing of these streams should be limited, as high-density cattle usage can cause severe degradation, sedimentation and siltation on the riffle habitats and gravel spawning areas downstream.

\section{Global Rank: GU}

State Rank: SU

\section{Global Rank Comments:}

The number of occurrences is fairly well known, and many spring creeks fall within private property. Very few spring creeks have had extensive biological inventories, due to private land issues, but the potential of discovering new snail species is high (D. Gustafson, pers. comm.). Due to the constant temperatures, these streams can act as fish refuges during the summer and winter months, and trout spawning areas on the gravel bottoms. 


\section{Intermountain Transitional River Ecosystem}

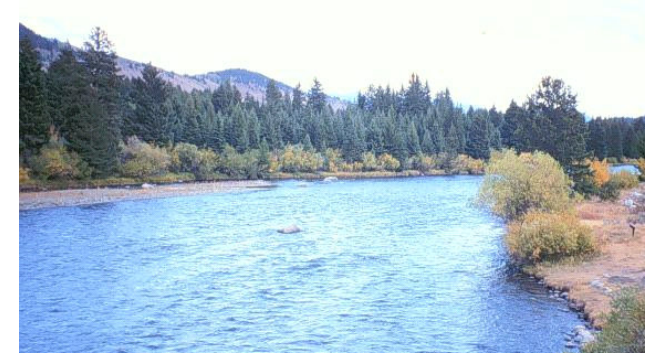

Figure 35. Big Hole River (B001) an Intermountain Transitional River

Ecosystem

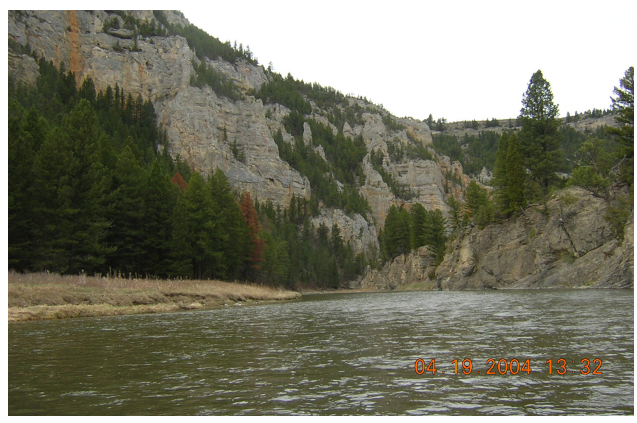

Figure 37. Smith River (B003) an Intermountain Transitional River Ecosystem

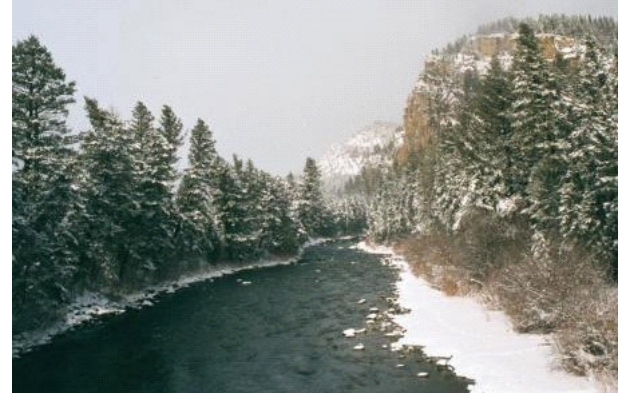

Figure 36. Gallatin River (B002) an Intermountain Transitional River Ecosystem

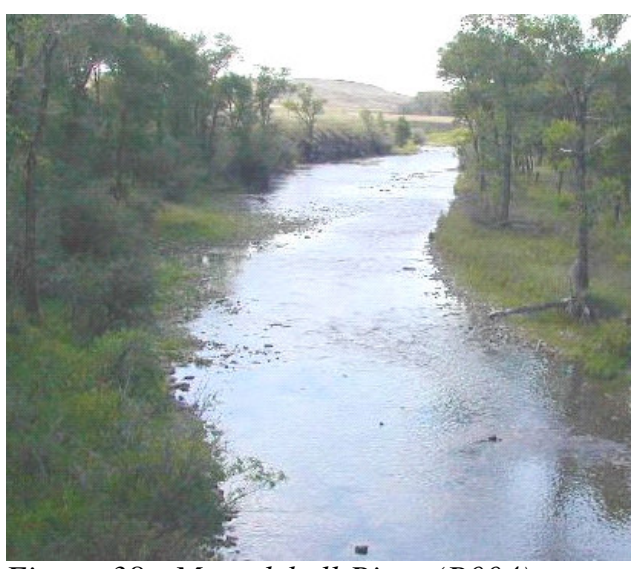

Figure 38. Musselshell River (B004) a dewatered representative of the Intermountain Transitional River Ecosystem

\section{Aquatic Ecological System Type: B001, B002 B003, B004, B007}

\section{Community Description}

\section{Summary:}

This well-known cool-cold water ecosystem occurs throughout the upper Missouri and Yellowstone River Drainages, and includes some of the most famous trout rivers in the country. Habitats occur in moderate elevation $(1200-2000 \mathrm{~m})$, medium-sized streams $\left(4^{\text {th }}-5^{\text {th }}\right.$ order, wetted width- $15-30 \mathrm{~m}$, average summer temperature: $<20^{\circ} \mathrm{C}$ ) with moderate gradient and a permanent flow with strong seasonal variability depending on melting snow pack from higher elevation mountainous areas. These rivers represent the ecotonal area from the high-elevation, steep-gradient, mountain stream and foothills to the prairie rivers to the east, and are typically direct tributaries of the Missouri and Yellowstone Rivers. These are classic freestone trout rivers (see Figure 35) with cobble and boulder riffle, run, pool configurations. Deep runs and pools with undercut banks and large woody debris provide the best fish habitats, while the riffles harbor the most diverse macroinvertebrate communities. The substrate of these streams is usually boulder/cobble riffles, cobble/gravel runs and pools, and silt on the margins or in the deepest pools. These are clear running rivers except during spring run-off or where cattle intrusions, bank erosion or stream incisement has caused sedimentation 
and silt deposits in the main channel areas. Over $50 \%$ of the sites in this ecosystem type were classified as impaired by sediments or de-watering by the MT DEQ.

\section{Fish Community:}

The members of this community are dominated by the Coolwater Transitional and the Traditional Trout Stream Assemblages. The fish community indicator species would typically be dominated by the native species: the Westslope cutthroat, mountain whitefish, mottled sculpin, longnose sucker, longnose dace, with the Yellowstone cutthroat trout $\&$ mountain sucker in the Yellowstone drainages. However, the introduced species of the stocked trout assemblage, the brown and rainbow trout, tend to dominate and become the focal species of these systems. One member of the Large Mainstem Warmwater River Assemblage (\#5) that occurs frequently in deeper, coldwater habitats of this system is the burbot, a potential SOC in the state. Additionally, the white sucker, walleye, northern pike and the exotic carp may be found at the warmer, lower end of this transitional gradient. The shallow gravel runs of these rivers provide spawning habitat for downstream populations of brown trout during their fall migration, and rainbow trout and sucker species in the spring. The Big Hole Assemblage (SPA \#6) is a unique assemblage found only in the Big Hole River drainages and includes the indicator species, fluvial arctic grayling (candidate for federal threatened status) and the redside shiner.

\section{Macroinvertebrate Community:}

This diverse community consists of members of the Medium Cool-Water Transitional Assemblage, the Traditional Trout Stream assemblage, Medium Mountain Stream Community and the Foothills Transitional Assemblage. The community indicator species are characterized by main channel, fast current stonefly and caddisfly species, Pteronarcys californica, Hesperoperla pacifica, Brachycentrus americanus, Arctopsyche grandis, Hydropsyche, Glossosoma, Lepidostoma and the tipulids: Hexatoma and Antocha. Mayflies are diverse and contain many genera, including Baetis, Ephemerella, Serratella, Rhithrogena, Drunella and Epeorus. As these transitional rivers proceed downstream and begin to warm $\left(>17^{\circ} \mathrm{C}\right)$ or are sediment impaired, degraded or are dewatered, they will quickly lose the Traditional Trout Stream and Medium Mountain Stream Community (\#4 and 90), and shift to the mayfly, caddisfly, beetle and dipteran species that form the Medium Cool-Water Transitional Assemblage (\#1) and the Foothills Transitional Assemblage (\#105), with indicator species: Hydropsyche, Optioservus, Baetis tricaudatus, Brachycentrus occidentalis, Helicopsyche borealis, Corynoneura, Prosimulium, Amiocentrus aspilis, Lara, Phaenopsectra, Plauditus, Narpus. Populations of the western pearlshell mussel have been reported from this river ecosystem, although the populations may be in decline.

\section{Range:}

The Intermountain Transitional River Ecosystem has been identified in the rivers that dominate the trout fishing scene throughout central and southwest Montana; these include, the Smith, Jefferson, Madison, Gallatin, Beaverhead, Big Hole, Dearborn, Sun and the mainstem Missouri from Three Forks to Cascade. In the Yellowstone drainage, the mainstem Yellowstone River from Gardiner to Big Timber, Clarks Fork of the Yellowstone, the lower Boulder, Stillwater, and Shields Rivers. The Middle Missouri/Musselshell Drainages contain the representatives: Judith and Musselshell Rivers.

\section{Management:}

Grazing and livestock use around the riparian areas of this ecosystem is common and can have strong local effects resulting in sedimentation and a shift of the macroinvertebrate communities from a Traditional Trout Stream Assemblage (\#4) to the Medium Cool-Water Transitional Assemblage (\#1), and a shift in fish communities from native cutthroat trout to invasive introduced species, such as the 
brook trout. Grazing of these streams should be limited, as high-density cattle usage can cause severe degradation, bank erosion, sedimentation and siltation on the riffle habitats and gravel spawning areas downstream. Water diversions lower in the foothills for agriculture may be an issue for this ecosystem since these streams usually flow onto private lands as foothills grade into the valleys and they decrease in elevation and gradient.

Global Rank: G5

State Rank: S4

\section{Global Rank Comments:}

The number of quality occurrences is unknown, but probably common. In Montana, this community is reported from $\sim 75$ sites within the Intermontane Foothills and Valleys regions from most mountain ranges in the state. 


\section{Small Foothills River Ecosystem}

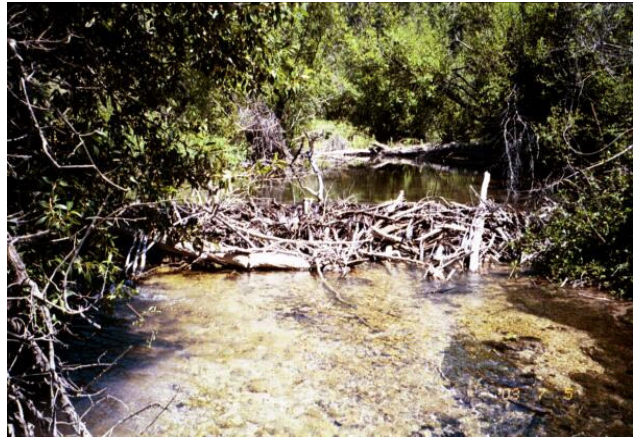

Figure 39. Pryor Creek (D001) a small foothills transitional stream with a beaver dam in the Custer National Forest

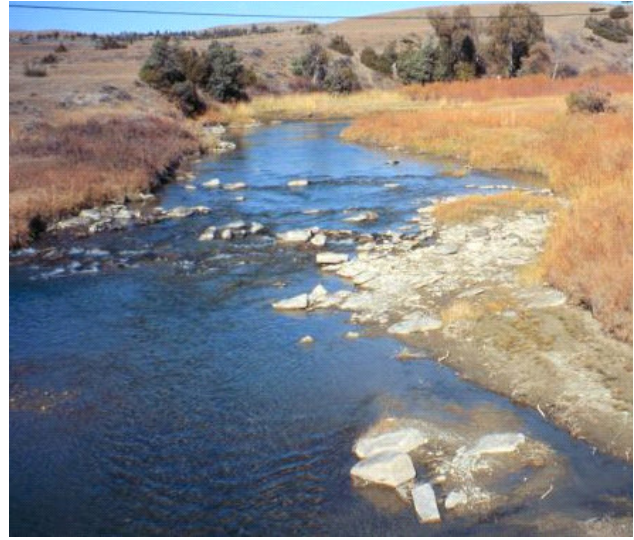

Figure 40. Sweetgrass Creek (C002) a small foothills transitional river near Big Timber, MT

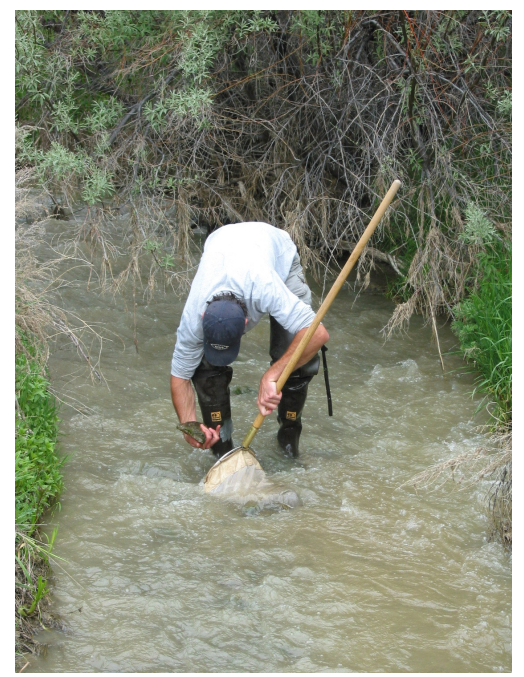

Figure 41. Bear Creek (C001) a small foothills transitional river with slight sediment impairment near Belfry, $M T$

\section{Aquatic Ecological System Type: C001, C002, C003, C004, D001}

\section{Community Description}

\section{Summary:}

This ecosystem is found in the moderate elevation $(1200-2000 \mathrm{~m})$, upland foothill streams of the Montana Foothills and Valleys Ecoregion or Middle Rockies mountain ranges as they decrease in elevation $\&$ gradient. These small-medium $\left(2^{\text {nd }}-4^{\text {th }}\right.$ order, average wetted width $-5 \mathrm{~m}$, average summer temperature: $<20^{\circ} \mathrm{C}$ ) moderately flowing rivers have permanent flow with strong seasonal variability depending on melting snow pack from higher elevation mountainous areas. These streams represent the transitional areas of the high gradient mountain stream communities to the intermontane or prairie rivers in the east. The surrounding landscape is transitional as well, with coniferous forests giving way to scrubland and sage, with riparian woody species. Often, beaver pond complexes are 
characteristic habitats on these streams (Figure 39). Beavers find suitable conditions and dam building materials as the foothills stream gradient decreases. These ponds provide substantial trout habitat, but can warm beyond the tolerance of cutthroat trout, and the native cutthroats will usually be pushed to the upstream reaches by the more aggressive brook trout. The substrate of these streams are usually boulder/cobble riffles, gravel/sand runs and pools, and silted in beaver ponds with large woody debris.

\section{Fish Community:}

The members of this community consist of the Coolwater Transitional Community, and the Traditional Trout Stream Assemblage. The indicator species would typically be characterized by the native species; the Westslope Cutthroat trout, mountain whitefish, mottled sculpin, the longnose sucker, longnose dace with the mountain sucker included in the Yellowstone drainages. However, the introduced species of the stocked trout assemblage, the brook trout and rainbow trout, tend to dominate and become the focal species of these systems. Additionally, the exotic carp, white sucker, lake chub and fathead minnows of the Core Prairie Stream Assemblage may be found at the warmer, lower end of this transitional gradient in the prairie regions. The shallow riffle areas of the larger foothills rivers may provide spawning habitat for downstream populations of brown trout during their fall migration, and suckers, dace and rainbow trout in the spring.

\section{Macroinvertebrate Community:}

The reference condition community is dominated by the Traditional Trout Stream assemblage, with some members of the Medium Cool-Water Transitional Assemblage and the Foothills Transitional Assemblage. The community indicator species are characterized by main channel, fast current mayfly, stonefly and caddis species, Pteronarcys californica, Hesperoperla pacifica, Brachycentrus americanus, Rhithrogena, Arctopsyche grandis, Lepidostoma spp., and the tipulid: Antocha. As the foothills streams proceed downstream and begin to warm $\left(>17^{\circ} \mathrm{C}\right)$ or are sediment impaired, degraded or are dewatered, they will quickly lose the Traditional Trout Stream community (\#4) and shift to the mayfly, caddisfly, beetle and dipteran species that form communities Medium Cool-Water Transitional Assemblage (\#1) and \#105 with indicator species: Hydropsyche, Optioservus, Baetis tricaudatus, Brachycentrus occidentalis, Helicopsyche borealis, Corynoneura, Constempellina, Prosimulium, Amiocentrus aspilis, Lara, Phaenopsectra, Plauditus, Narpus. Populations of the western pearlshell mussel have been reported from this river ecosystem, although the populations may be in decline.

\section{Range:}

The Small Foothills Rivers Community type has been identified in the Custer National Forest (Beartooth District), Pryor Mountains, foothills of the Belts, Judiths and other isolated mountain ranges. Many BLM held lands contain this community as the National Forest lands gradate down to the foothills and valleys. The Middle Missouri/Musselshell Drainages contain the most representatives of this community type in the database.

\section{Management:}

Grazing and livestock use around the riparian areas of this ecosystem is common and can have strong local effects resulting in sedimentation and a shift of the macroinvertebrate communities from a Traditional Trout Stream Assemblage (\#4) to the Medium Cool-Water Transitional Assemblage (\#1), and a shift in fish communities from native cutthroat trout to invasive introduced species, such as the brook trout. Grazing of these streams should be limited, as high-density cattle usage can cause severe degradation, bank erosion, sedimentation and siltation on the riffle habitats and gravel spawning areas downstream. Water diversions lower in the foothills for agriculture may be an issue 
for this ecosystem since these streams usually flow onto private lands as foothills grade into the valleys and they decrease in elevation and gradient.

\section{Global Rank: GU}

State Rank: S4

\section{Global Rank Comments:}

The number of occurrences is unknown, but probably abundant. In Montana, the community is reported from over 200 sites within the Foothills and Valleys regions, and in the transitional zones from most mountain ranges in the state. 


\section{Small Pristine Mountain Stream Ecosystem}

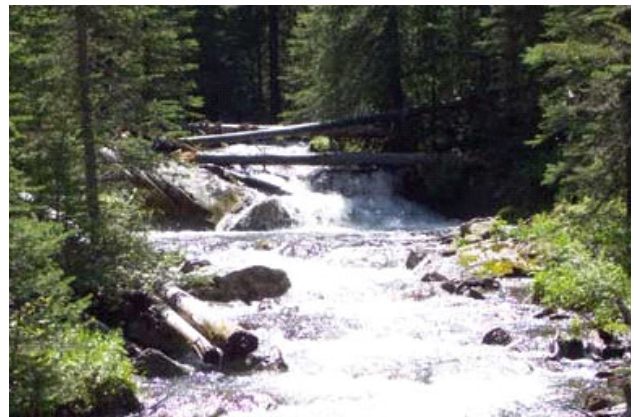

Figure 42. Tenderfoot Creek (D002) a

Small Pristine Mountain Stream in the Belt Mountains

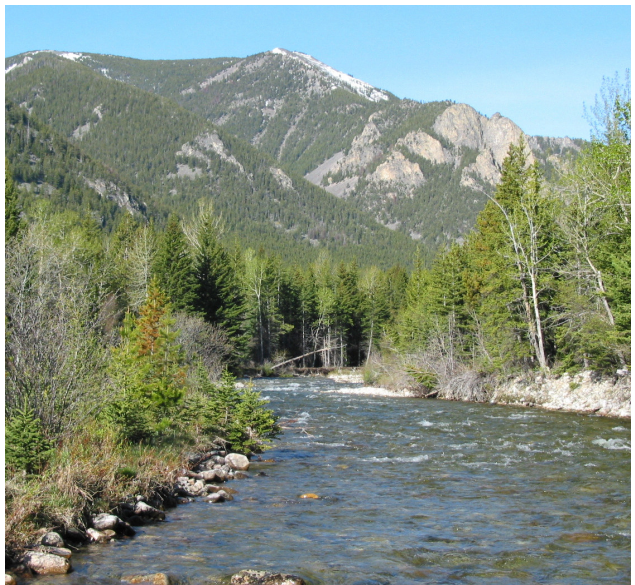

Figure 43. Boulder River (D004) a Small Pristine Mountain Stream in the Beartooth Mountains

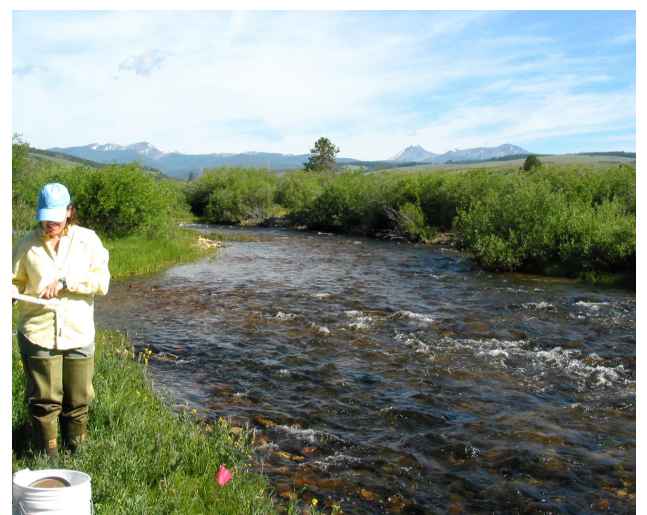

Figure 44. LeMarche Creek (D004) a

Small Pristine Mountain Stream tributary

to the Big Hole in the Anaconda-Pintlar

Mountains

\section{Aquatic Ecological System Type:}

D002, D003, D004, D010

\section{Community Description}

\section{Summary:}

This ecosystem is found in the mountainous, moderate-high elevation $(1600-2500 \mathrm{~m})$, forested, moderately confined-channel streams of the Middle Rockies Ecoregion. These small-medium ( $2^{\text {nd }}-3^{\text {rd }}$ order, average wetted width- $7 \mathrm{~m}$, average summer temperature: $\left\langle 15^{\circ} \mathrm{C}\right.$ ) moderately flowing streams have permanent flow with strong seasonal variability depending on melting snow pack from higher elevation mountainous areas, and are often within National Forest Service boundaries. These streams represent the transitional areas from the alpine stream communities to the foothills and intermontane rivers and provide substantial habitat for Montana's native cutthroat trout populations, which thrive in the coldwater temperatures and complex in-stream habitats. The geomorphology of these streams is usually a step-pool configuration with substrate dominated by boulders and cobbles with gravel in the short pools. Large woody debris from the surrounding hillslopes can provide significant channel material and additional substrate to these streams. 


\section{Fish Community:}

The members of this community are dominated by the Traditional Trout Stream Assemblage, specifically the Small Trout Stream Assemblage (Sub-Group \#7a)- which contains the Westslope Cutthroat Trout and the mottled sculpin in high quality Missouri drainage streams, and the Yellowstone Mountain Stream Assemblage (\#10), which includes the Yellowstone cutthroat trout, Golden trout (introduced) and sculpin. Unfortunately, the introduced brook and rainbow trout have pushed many native cutthroat trout populations to the brink, through aggressive competition (brook trout) and hybridization (rainbow trout). The mottled sculpin usually persists in all of these aquatic ecological stream types, but single species assemblages of the Westslope and Yellowstone Cutthroat Trout occur in many streams that have sufficient downstream barriers to prevent the dispersal of the sculpin upstream. Interestingly, these downstream barriers have allowed the persistence of high quality, intact small mountain stream communities by impeding the colonization of introduced species into the pure cutthroat trout areas.

\section{Macroinvertebrate Community:}

This diverse community of coldwater stenotherms consists of members of the Pristine Mountain Stream (\#58) and the Medium Mountain Stream Assemblage (\#90). The community indicator species are characterized by intolerant, main channel, fast current mayfly, stonefly and caddis species, Baetis bicaudatus, Caudetella spp., Drunella spp., Epeorus spp, Cinygmula, Zapada spp. Megarcys, Doroneuria, Sweltsa, Paraperla, Micrasema, Neothremma, Parapsyche, Neophylax sp., numerous Rhyacophila sp. groups, and the cold-water dipterans, Rhabdomastix, Bibiocephela, and Glutops. As the mountain streams proceed downstream and begin to warm $\left(>15^{\circ} \mathrm{C}\right)$, a dominance shift occurs to the Medium Mountain Stream Invertebrate Assemblage. Populations of the western pearlshell mussel have been reported from this stream type, and this ecosystem may be their stronghold in the state east of the continental divide.

\section{Range:}

In Montana, the Small Pristine Mountain Stream community is reported from over 100 sites within the Middle Rockies Ecoregions, originating from the Beaverhead and Belt Mountains or the Yellowstone Highlands. These subsections include streams in many of Montana's mountain ranges, including the Beartooths, Absorokas, Elkhorns, Big Belts, Little Belts, Crazys, Gallatin-Madison-Bridgers, Anaconda-Pintlers, Pioneers and the Big Snowy Mountains. These ecosystems typically fall within the boundaries and under the protection of the National Forest Service lands and wilderness areas.

\section{Management:}

Due to the confined valley nature of these streams, the largest management issue involves the assurance that the riparian zone remains intact. Disturbances in the riparian zone (e.g. logging) can have severe water quality impacts from bank erosion, sedimentation, increased stream temperatures, silt deposits and loss of large woody debris. Grazing and livestock use around the riparian areas does occur, even in the National Forest Lands, and can have strong local effects resulting in sedimentation and stream widening at cattle crossings.

\section{Global Rank: G5}

State Rank: SU

\section{Global Rank Comments:}

The number of occurrences is unknown, but probably abundant. These stream ecosystems are abundant across the mountain ranges of North America and are usually afforded some measure of protection being in National Park, or under National Forest Service land ownership. 


\section{Alpine Mountain Stream Ecosystem}

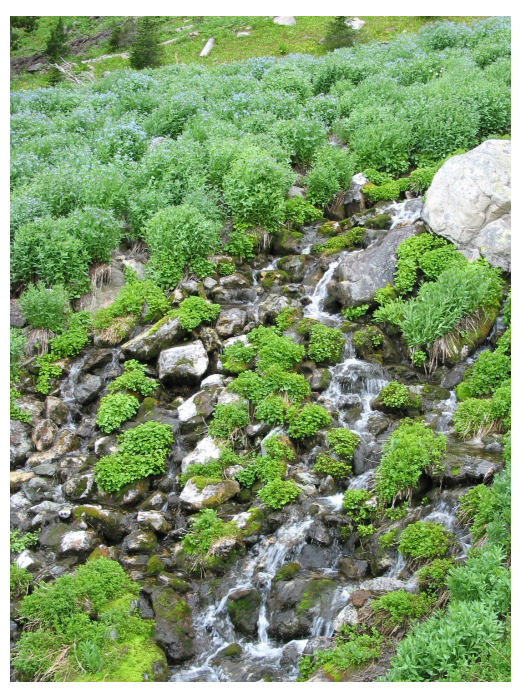

Figure 45. E. Fork Pintlar Creek (E001) a fishless Alpine Mountain Stream in the Anaconda-Pintlar Mountains

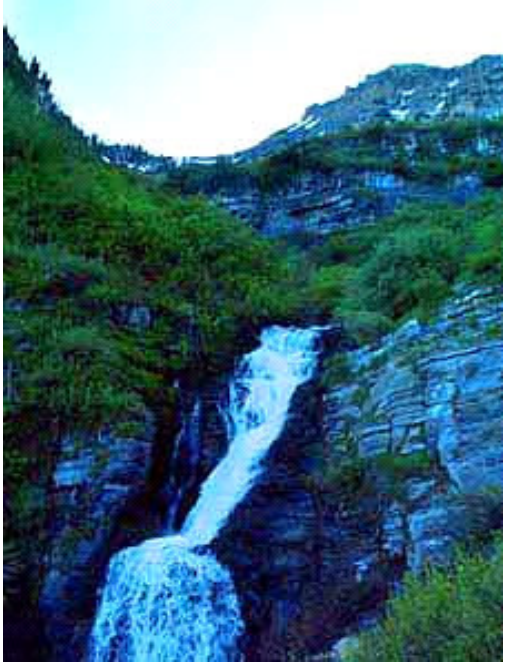

Figure 46. Hellroaring Creek (E001) a steep Alpine Mountain Stream in the Beartooth Mountains

\section{Aquatic Ecological System Type: D011, E001, E002, E003}

\section{Community Description}

\section{Summary:}

This ecosystem is found in the high elevation ( $>2500 \mathrm{~m}$ ), mountainous streams of the Middle Rockies Ecoregion. These small $\left(1^{\text {st }}\right.$ and $2^{\text {nd }}$ order, average wetted width- $2 \mathrm{~m}$, average summer temperature: $<10^{\circ} \mathrm{C}$ ) moderately flowing streams have permanent flow with variability depending on melting snow pack. These streams can be directly snow-pack or glacier-fed (Figure 45) or flow from alpine lakes formed in the mountain cirques. The geomorphology of these coldwater streams can vary from a high gradient, step-pool configuration with substrate dominated by boulders and cobbles with gravel in the short pools to a low gradient lake outflow dominated by cobbles and gravel.

\section{Fish Community:}

The smallest alpine creeks are steep, shallow and fishless (Figure 45). If fish are present in the drainage or have access to the streams from a lake outlet, they would typically be members of a single species assemblage dominated by the Westslope or Yellowstone Cutthroat Trout depending on the drainage, or the introduced Golden or brook trout. This assemblage is dictated by the fishstocking history of the high mountain lakes in the area. Native species management plans are in place by management agencies, but oftentimes, high mountain lakes are still stocked with introduced species. Sufficient downstream barriers (waterfalls, boulder step-drops) usually exist to prevent the dispersal of the mottled sculpin into this system, as well as impeding the colonization of introduced species (brook trout) into the pure cutthroat trout areas.

\section{Macroinvertebrate Community:}

This diverse community of coldwater stenotherms consists primarily of unique members of the Pristine Mountain Stream Assemblage (\#58) and the Medium Mountain Stream Assemblage (\#90). The community indicator species are characterized by intolerant, shredder and scraper mayfly, 
stonefly and caddis species, Drunella spinifera, Epeorus grandis, Yoraperla, Soliperla, Zapada frigida, many Leuctridae and Capniidae species and Oligophlebodes, numerous predatory Rhyacophila sp. groups, and the cold-water dipterans, Thaumalidae, Bibiocephela, and Glutops. As the alpine mountain streams proceed downstream, begin to lose elevation/gradient and warm (>10 ${ }^{\circ} \mathrm{C}$ ), a dominance shift occurs to the Small Medium Mountain Stream Invertebrate Assemblage.

\section{Range:}

In Montana, the Alpine Mountain Stream community is delineated from 20 sites within the Middle Rockies Ecoregions, originating from the Beaverhead and Belt Mountains or the Yellowstone Highlands. These subsections include streams in many of Montana's mountain ranges, including the Beartooths, Absorokas, Elkhorns, Big Belts, Little Belts, Crazys, Gallatin-Madison-Bridgers, Anaconda-Pintlers, Pioneers and the Big Snowy Mountains. These ecosystems typically fall within the boundaries and under the protection of the National Forest Service lands and wilderness areas.

\section{Management:}

Due to the high-altitude nature of these streams, anthropogenic disturbances are usually minimal, but may include high impact recreational use (e.g. stock use, campsites, stream crossings). A long-range disturbance and the eventual demise of these ecosystems could be global warming. The communities inhabiting these streams are glacial relicts taking refuge from the last ice age, and are confined to these high elevations due to temperature requirements. If these cold-water dependent communities experience increased, unsuitable temperatures from snow pack and glacier reductions, they have nowhere to go. Due to the inherent inaccessibility of these systems, few have been inventoried, but may contain species of concern, as has been reported with the Glacier Meltwater Stonefly (G2S1) from the glacier-fed streams of Glacier Park.

Global Rank: G5

State Rank: S4

\section{Global Rank Comments:}

The number of occurrences is unknown, but probably abundant. These stream ecosystems occur in the alpine zones of high mountain ranges across western North America. Because the alpine systems in Montana contain unique and intolerant fauna with many on the SOC list, we should be concerned about the long-term monitoring and condition of these ecosystems warranting them a state rank of S4. 


\section{DisCUSSION}

\section{Aquatic Ecosystem Discussion}

As expected, broad-scale ecoregional processes showed the greatest influence on the distribution of Montana's aquatic ecosystems. Level III ecoregions (Omernik 1995) primarily explained our broadest patterns of aquatic community diversity. The mountainous regions harbored significantly different communities than the plains, and the transitional foothills regions were also distinct. Aquatic Ecosystems classified within the mountains and foothills demonstrated significant correspondence with both the macroinvertebrate and fish communities. Fish assemblages from small streams of the Northern Glaciated plains ecoregion were significantly different from those of the Northwestern Great plains, although this was not reflected in the macroinvertebrate groups. Many of our uniquely classified warm-water ecosystems contain the presence of very similar biological communities; often having several of the same fish or macroinvertebrate assemblages present. Zorn et al. (1998) found co-occurrence of up to four fish species assemblages in two differently classified rivers in Michigan with the main difference being the dominance of specific members of the assemblages. In some cases during the process of our ecosystem classification and delineation, we relied more heavily on the fish assemblage differences than the macroinvertebrate assemblages. The Northern Glaciated and Northwestern Great Plains small streams, which are vastly different abiotically, had indistinguishable macroinvertebrate assemblages and the driving biological distinction between them was the Northern Redbelly Dace fish assemblage. We discuss these problems further under the individual community discussions. Transitional environmental conditions exist and within these "grey areas" species overlap and community intergrades will occur; finding ways to address these within the classification is challenging and will involve additional work.

Although one goal of classifying ecological communities is to be able to predict occurrences across watersheds given a specific set of landscape features, we do not intend to imply that all systems within a defined ecosystem classification are equal. Suplee (2004) found that within a range of Montana Northern Glaciated Plains streams (classified as two stream ecosystem types with our system), different sites from one region had very diverse characteristics (riparian type, morphology, etc.) and ranged from Rosgen C3 type streams (slightly entrenched with cobbles) to $F$ and $G$ types (deeply entrenched, with silt) (Rosgen 1996). To better understand the data it was necessary to develop stream subgroups and treat multiple streams within one ecological drainage unit and even the same watershed very differently.

It is quite apparent that streams within classified ecosystem types will vary according to the local watershed conditions, but this variance does not preclude them from clustering together based on most factors used in the delineation process. For example, one Large Prairie River that may be unique as a rare and special ecosystem is the Powder River. It supports not only a diverse fish community but represents the sole remnant of a once widespread Great Plains un-dammed large prairie riverine community of fish and invertebrates. All other representatives of the Large Prairie River ecosystem in Montana have dams or significant diversion structures present that have contributed to the loss of some of the unique biological assemblages that are still found in the Powder. Hubert (1993) describes the Powder River as unique in that it supports 32 species of fish with 25 species being native to the drainage. The Powder River also provides substantial habitat for the sturgeon chub, a species that has been extirpated from much of its historic range, and its populations in the Powder contributed to its removal as a candidate for Endangered Species listing by the USFWS (2001).

In a study on Wyoming's fish fauna, the Powder River was identified as supporting an abundance of species adapted to turbid rivers (flathead chub, plains minnow, western silvery minnow, river carpsucker, and channel catfish that have been 
greatly reduced or eliminated from other drainages) (Patton et al 1998). Rehwinkel (1978) concluded that the Powder River supported the most unique community of benthic invertebrates in Montana. More recent sampling by Dr. Dan Gustafson (MSU) discovered numerous species of exceedingly rare invertebrates, such as the sanddwelling mayfly community. These species were probably quite common in large prairie rivers, but have been eliminated throughout most of their historic range due to impoundments and other river alterations. As one of the few rivers of its size lacking a main stem dam, the Powder River may provide the last opportunity to preserve this important component of Montana's and North America's natural heritage.

Drastic and harsh environmental conditions in the prairie ecosystems are often reported (Dodds et al. 2004, Matthews 1988). This was true of our prairie ecosystem aquatic systems, as well. During our field sampling, the majority of the $1^{\text {st }}, 2^{\text {nd }}$ and even third Strahler order streams of the prairie ecosystems, especially in the Northwestern Great Plains ecoregion, were dry due to Montana's extended drought (Appendix B). This posed a serious setback in the number of macrohabitats sampled, because in any given watershed over half and probably closer to $3 / 4$ of the existing stream reaches were dry. Moreover, communities of fish and macroinvertebrates were concentrated into fewer available mainstem stream reaches possibly affecting the sampled community structure. Stream reaches containing particular fish communities five years ago were now dry, and those dry in 2004 were flowing in June 2005 because of a wet spring. Are the communities recolonizing these stream reaches after all these years, similar to those previously reported? Much work needs to be done to explain and predict how a prairie stream ecosystem will react under a given set of environmental circumstances. Bramblett (20003) found fish community IBI's to be relatively stable over a two-year period, although some of the revisit sites were dry. Long-term data sets (monitoring over spatial \& temporal variability) are needed to explain the patterns of prairie stream fish and aquatic macroinvertebrates. In the words of Matthews (1988), "You can't truly understand a prairie stream unless you've been there at least a year.........well that should probably be more like 5 , or maybe 10 years."

\section{Macroinvertebrate Community Relationships}

The factors differentiating macroinvertebrate community types were variables associated with the longitudinal and altitudinal variation of streams. Two of the 12 macroinvertebrate groups were exclusive to Montana's higher elevation streams. Within the forested streams, smaller streams $\left(1^{\text {st }}\right.$ $3^{\text {rd }}$ order) contained substantially different macroinvertebrate communities compared to fourth order and larger streams. Longitudinal food resource shifts in forested streams have been shown to influence macroinvertebrate communities (Vannote, et al. 1980; Minshall et al. 1985). According to the River Continuum Concept, collectors and shredders, which utilize coarse particulate organic matter dominate the first through third order streams (Vannote, et al. 1980). Downstream, as stream size increases (fourth order and greater), conditions become more opencanopied, with more light entering the stream increasing primary production (diatoms, periphyton, etc), and scrapers and grazers become the dominant macroinvertebrate groups. Eventually in the largest order streams ( $5^{\text {th }}$ and larger), only fine organic particulate matter is available, and filter feeders, collector gatherers and predators become the most common groups (Large Prairie and Collector-Filterer Assemblages); these are the groups that we predict the mussel communities of the Milk, Musselshell, Missouri and Yellowstone Rivers will be associated.

In the smaller forested-streams, such as the Pristine Mountain and Medium Mountain Stream Ecosystems, shredders and scrapers were the most common feeding guild among the indicator taxa. In Group 40, the Medium Prairie River Side-Channel Community, predators were the most common feeding group, but other feeding groups like filterers and collectors were also present. Generally, our community groupings reflect some of these changes in feeding groups with increasing stream 
size. Unfortunately, prairie streams do not fit the River Continuum Concept (Stagliano and Whiles 2002), and stream macroinvertebrate communities vary according to permanence of flow and degrees of turbidity or impairment (Dodds et al. 2004).

Thus, macroinvertebrate groups of the prairie were not clearly differentiated by stream size or food resources utilization.

Stream gradient varies substantially within our study region and corresponds to changes in velocity and substrate. In areas with low gradient and sandy or silty habitat, macroinvertebrate taxa capable of dealing with unstable substrate are present (Assemblages 9, 11, 12 and 37). The mayfly genera, Caenis and Tricorythodes are indicator genera associated with the Prairie Stream (9) and the Large Prairie River (11) Assemblages respectively, and have modified structures for protecting gills from abrasion from fine materials. Additionally, the mayfly, Hexagenia (11) uses its gills to circulate silt and depositional materials from its burrow (Merritt and Cummins, 1996).

Numerous adaptations such as these are found within the many species of these distinct macroinvertebrate assemblages. Within the high current velocity and stream gradient sites, macroinvertebrate groups 58 and 90, Pristine Mountain and Medium Mountain Stream Assemblages, contain species of the dipteran families, Blephariceridae and Deuterophlebiidae, which have suction-cup type devices to hold them to smooth boulder surfaces in the swift currents. Additionally, mayfly species associated with these habitats (e.g. Drunella doddsi, Rhithrogena) have modified gills to accomplish this same task.

Five community groups showed some trends in pollution tolerance along an agricultural and land cover gradient, but these were also auto-correlated with increasing water temperatures.

Macroinvertebrate assemblages found in areas with the highest levels of agriculture and developed land, such as Groups 37, 38 and 40, have indicator taxa with relatively high mean tolerance values most likely magnified by the degree of watershed disturbance. Whereas, the Pristine Mountain and Medium Mountain Assemblages occur in streams with little watershed disturbance and have relatively intolerant indicator taxa consisting of mainly cold-water EPT (Ephemeroptera, Plecoptera, and Trichoptera) taxa. Anthropogenic water temperature increases through dewatering or logging in watersheds of medium-sized, cold-water rivers can shift the assemblage from an intolerant Medium Mountain Stream Community to the more tolerant Medium Coolwater Transitional Assemblage. Likewise, an unimpaired foothills transitional stream will be dominated by the Traditional Trout Stream Assemblage until warming or anthropogenic impacts cause a shift to the Medium Coolwater Transitional or Small Foothills Transitional Assemblage.

In addition to land cover, the underlying geology influences stream water quality and physical geomorphology. Some researchers have successfully distinguished stream macroinvertebrate community types based on ecoregion (Feminella et al., 2000; Rabeni and Doisy, 2000), while others have not found this correlation (Hawkins and Vinson 2000). In this study, coarse trends in macroinvertebrate communities reflect the degree of elevation change and associated factors (e.g. substrate, current velocity, temperature) within a stream drainage, most noticeably in the forested to foothills ecoregion streams. For example, the distinction between the Pristine Mountain Stream and Medium Mountain Stream Assemblages (SPA 58 and 90) is most attributable to the natural mountain stream progression from steep to moderate gradient, and the associated decrease in current velocity, with the channel type going from a cascade/step pool to plane-bed morphology.

Despite some success with the classification to detect impaired stream types in the Mountain and Foothills Ecoregions, it is apparent that the macroinvertebrate classification, at this level, does not adequately distinguish impaired from reference conditions within the prairie ecoregions. Both impaired and reference prairie stream sites clustered together and contained the same macroinvertebrate assemblages, albeit with slightly different dominant species. Bramblett et al. (2003) and Suplee (2004) have experienced similar problems when evaluating prairie stream 
macroinvertebrate communities as bioassessment tools in the prairie regions of Montana. Further analysis with prairie stream types separated from the other ecoregions will be conducted, if time and future funding become available.

\section{Macroinvertebrate Communities with Macrohabitats}

Four distinct community types occur along specific macrohabitat types and substrate characteristics. The Large River Sand-dwelling Mayfly Assemblage contains a group of globally rare mayflies only found in the vast sandy substrate, run/pool areas of large moderate gradient rivers, a habitat that is rarely sampled in most biomonitoring studies. The Filterer-Collector Assemblage (37) is associated with substrate characteristics in a negative context; the occurrence of this assemblage usually indicates the presence of shifting sediments in riffle/run habitats and newly colonized substrates representing some sedimenttype impairment to the river system. Large River Slow Current Assemblage and Medium Prairie River Side-Channel Community are two assemblages that represent multi-habitat sampling occurring at the margins of pools, silted sidechannels, large woody debris areas or in larger prairie stream samples that do not contain riffles. These assemblages are highly tolerant to disturbance but are natural members of all prairie river ecosystems; therefore, multi-habitat samples in prairie streams will always appear more impaired than the associated riffle/run samples. Bramblett (2003) reported that prairie stream riffle macroinvertebrates responded better to a range of impairments, and that the pool macroinvertebrate communities were less likely to differentiate impaired versus reference site conditions.

Some macroinvertebrate community types appear to occur only in discrete locations or ubiquitous community types can delineate a unique stream type. For example, the Small Transitional Foothills Assemblage (SPA \#105) was unique to one watershed and may constitute a rare assemblage of macroinvertebrates. Although upon review of the individual indicator species of this group (ex.
Helicopsyche borealis, Corynoneura, Prosimulium, Amiocentrus aspilis, Lara, Plauditus, Narpus concolor), many of these taxa appear in other transitional foothills river samples and throughout the database, though not in the dominance or community structure found in the eight streams delineated in the analysis. Therefore, this particular assemblage of widespread species formed a unique community based on some artifact of local habitat conditions, or potentially a patchiness-sampling artifact. The reference condition Perennial Prairie Spring Community contains an assemblage that resembles the ubiquitous and widespread Medium Coolwater Transitional Assemblage, a community associated with the much larger coolwater stream system that doesn't occur within many areas of the prairie ecoregions. Thus, its appearance in a different stream type in the Great Plains ecoregion makes it unique.

\section{Macroinvertebrate Community distribution within pilot watersheds}

Watersheds that appeared relatively uniform in macrohabitat types, physical characteristics and land cover had fewer reported macroinvertebrate communities. The Cottonwood Creek Watershed was set in a Northern Glaciated landscape that was uniform in elevation and macrohabitat types (17 class codes), and only three invertebrate community types were identified; the dominant type being the prairie pool assemblage ( 9 of 12 sites) (Appendix B). The Pryor Creek Watershed had more diverse macrohabitats (28 class codes) and elevation variation, and subsequently more community groups were identified (4 assemblages). These Pryor Creek assemblages also showed the broadest ranging environmental adaptations, from the Traditional Trout Stream Assemblage in the Pryor Mountain Foothills and the Medium Coolwater Transitional Assemblage in the Pryor mainstem to the tolerant Prairie Pool Assemblage in the low elevation prairie-stream tributaries.

The Lower Tongue River watershed had the most community types (6), perhaps owing to its diverse number of macrohabitats (48 class codes). 
Alternatively, this could be because of numerous agencies sampling efforts taking both targeted-riffle and multi-habitat samples in the mainstem Tongue River and its tributaries. Sampling effort in a watershed has been found to increase the number of community types identified (Knightingale 2003). Although, the Lower Tongue River, being entirely in the Powder River Basin subsection does not contain as diverse a group of assemblages as the Pryor Creek Watershed. The Lower Tongue contained all warm-water macroinvertebrate groups with the most tolerant Medium Prairie River Side-Channel Community dominating the Tongue River samples.

\section{Fish Community Relationships}

Fish communities responded to four primary environmental factors: stream order (or upstream linkages), river basin size, reservoir influences and fish species introductions. The strongest determinants for fish habitat are temperature and stream order, along with the correlated factors of linkage and elevation. In both the Missouri and the Yellowstone datasets, high-order, low gradient and elevation, warmwater fish communities clearly separate out from higher-gradient, headwater, coldwater fish communities. Stream order (Fairchild et al. 1998; McCormick et al. 2000), water temperature (Zorn et al. 1998) and stream gradient (Lyons 1989; Waite and Carpenter 2000) have been found to be important determinants of the distribution of fish communities. Increasing drainage area also directly relates to increasing fish diversity (Angermeier and Schlosser 1989, Bramblett et al. 2003), which is evident in the greater number of indicator species in our fish assemblages $(1 \& 2)$ in the medium and larger river systems. Additionally, link number upstream (\# of tributaries entering upstream of the sample point) was found to influence fish community distribution. Fairchild et al. (1998) and Matthews and Robison (1998) also found link number upstream to be an effective variable in explaining fish distributions. Clearly, measures of connectivity are important in defining fish communities (Matthews and Robison 1998, Bramblett and Fausch 1991). Many fish, even warmwater species, are migratory during their spawning periods (e.g. sauger, channel catfish, Holton 2003) or pioneering (e.g. white sucker, shorthead redhorse) and will opportunistically search for suitable habitats. If the conditions are favorable for fish species to migrate into a particular type of aquatic system, especially if linkages have connectivity to reservoirs or other pools of non-native fishes, then the community observed might be surprisingly different than what was expected. This was often the case in examining the fish data for D006 type streams (small, silted interrupted pools) that had white suckers co-occurring with fathead minnows and brook sticklebacks, the usual inhabitants.

The differences in the Yellowstone and Missouri drainages are zoogeographically subtle (Zelt et al. 1998), but can have significant predictive effects within the classification system. For instance, in the Missouri River drainage, a D006 type stream (small, silted interrupted pools) containing just fathead minnows is typical, while in the Yellowstone drainage the lake chub would more likely be the single species found in a similar D005 stream. The transitional cool-water community (SPA \#2c) associated with C001 streams is found more commonly in the Yellowstone drainages due to the increased probability of encountering mountain suckers in these drainages.

Warmwater fish communities grouped into six main categories, primarily corresponding to Aquatic Ecological Systems (Table 2): large rivers, medium rivers and small streams. There was an additional division of the small stream species into those primarily found in the Northern Glaciated Plains of the Missouri drainage (Redbelly Dace Assemblage SPA \#4) and the non-native Warmwater Sunfish Assemblage primarily found in the Yellowstone drainages. This species distribution pattern of the Yellowstone basin relates to the stocking history of some of the reservoirs in the basin (FWP MFISH 2004), as well as the known zoogeographic affinities of these native and introduced midwestern stream communities, which are at the westernmost limit of their distributions in southeast Montana. (Cross and Moss 1987, Holton 2003) 
In classifying Montana stream communities, the influence of fish stocking is considerable. We know that most streams and reservoirs in the state have been stocked with various species of fish at some time (FWP MFISH 2004). In addition to reducing native fish numbers through competition, stocked fish can often overwhelm a stream reach and totally displace the natives. Since non-native or stocked fish now represent self-sustaining communities, they have considerable influence on the stream ecosystems.

The coldwater and intermediate transitional fish communities (SPA \#2c, 6, 7, 8, and 10) were associated with a number of factors including drainage basin, stream order, land use, and most importantly, stocking history. Two environmentally similar coolwater streams in the Yellowstone basin would have historically contained members of the Coolwater Transitional Assemblage (SPA \#2c) characterized by mountain sucker, longnose sucker and longnose dace, but trout stocking in one of those streams over the years has led to the predominance of the Stocked Trout Stream Assemblage (SPA \#7) (characterized by brown, Salmo trutta and rainbow trout, Oncorhynchus mykiss). Thus, the current or historic troutstocking regime may be a defining factor in structuring the communities of many of these coolwater transitional streams.

Fish communities defined in this study did not significantly cluster by ecoregion, and homogenization of warmwater fish communities (mostly through fish stockings, bait bucket transfers and stream impairment) has been reported across Great Plains streams, potentially erasing ecoregion effects (Rahel 2000, 2002). However, the Northern Redbelly Dace assemblage showed a strong affinity to small Northern Glaciated Plains streams of the Missouri drainages and does not exist as a species group in the Yellowstone drainage. This species assemblage may be the first important focal community group to investigate further, since it contains two Montana Species of Concern and is severely limited by introduced gamefish, particularly northern pike.

Lyons (1989) found a statistically significant difference in fish communities at the ecoregion level, although McCormick et al. (2000) did not find a strong relationship between fish community and ecoregion. Allen et al. (1997) suggests that local spatial scales and instream habitat differences may be more important than larger geographic scales in determining fish assemblages. A great deal of unexplained variability is probably related to instream habitat features. Peterson and Rabeni (2001) verified the importance of habitat features like vegetation, depth, sedimentation, and coarse woody debris.

Another possible factor in the apparent lack of ecoregional differences we found is that our classification is based on fish data collected throughout a relatively long index period (JuneSeptember). Kessler et al. (1995) have shown the impact of seasonal changes even within this time period on fish communities. Our data shows how sampling during a varied spatial ( 7 river miles apart) and temporal period ( 2 months and 1 year apart) affects the fish species detected and ultimately can affect the predictive capabilities of the community classification (see Table 6). The fish species at Pryor Creek's river mile 6.5 site have only 2 species in common between the 2 sampling dates, and 4 and 5 fewer fish species than the June and August 13.5 river mile site sampling dates, respectively. If you were to examine those species data sets separately, you might come to the conclusion that they were 2 completely differentsized streams or at least more than 7 river miles apart in the watershed, since the fish community reported during the August visit at the 6.5 river mile site appears to indicate a much smaller reach further upstream. 
Table 6. The temporal and spatial variability of two Pryor Creek (C005) fish samples at 6.5 (left) and 13.5 (right) river miles from the confluence with the Yellowstone River

\begin{tabular}{|c|c|c|c|c|c|c|}
\hline Taxon & $\begin{array}{l}\text { June } \\
2003\end{array}$ & $\begin{array}{c}\text { August } \\
2003\end{array}$ & & $\begin{array}{l}\text { June } \\
2003\end{array}$ & $\begin{array}{c}\text { August } \\
2003\end{array}$ & $\begin{array}{l}\text { June } \\
2004\end{array}$ \\
\hline Channel Catfish & 3 & 0 & Channel Catfish & 17 & 4 & 1 \\
\hline Longnose Dace & 43 & 57 & Longnose Dace & 36 & 2 & 12 \\
\hline Fathead Minnow & 0 & 27 & Fathead Minnow & 80 & 14 & 15 \\
\hline Flathead Chub & 2 & 0 & Flathead Chub & 0 & 2 & 3 \\
\hline White Sucker & 2 & 26 & White Sucker & 12 & 60 & 20 \\
\hline \multirow[t]{5}{*}{ Shorthead Redhorse } & 27 & 0 & Shorthead Redhorse & 25 & 4 & 3 \\
\hline & & & Longnose Sucker & 3 & 0 & 0 \\
\hline & & & Common Carp & 1 & 8 & 8 \\
\hline & & & Mountain Sucker & 2 & 1 & 2 \\
\hline & & & Western Silvery Minnow & 2 & 0 & 0 \\
\hline Total Species & 5 & 3 & Total Species & 9 & 8 & 8 \\
\hline $\begin{array}{l}\text { Species in Common } \\
\text { With Initial Sample }\end{array}$ & & 2 & & & 7 & 7 \\
\hline
\end{tabular}

This seasonality factor may be especially important on many prairie streams that have a significant reduction in their flow regime shortly after summer begins, and fish communities migrate downstream to the larger stream orders. Further analysis of the temporal influence of seasons and better links with abiotic variables may produce a better fish community classification.

\section{Fish Community distribution within pilot watersheds}

Community distribution among the pilot watersheds varied from Headwater Trout Stream Assemblages in the uppermost reaches of the Pryor Creek Watershed to Intermittent Prairie Pool single species assemblages in the tributaries to the Tongue River or Cottonwood and Frenchman Creeks (Appendix B). Pryor Creek Watershed fish assemblages also showed the broadest environmental variability from the Headwater Trout Stream Assemblage in the Pryor Mountain Foothills and the Coolwater Transitional Assemblage in the Pryor mainstem to the Small Northwestern Prairie Stream and Medium Prairie River Communities further downstream.

Based on the aquatic ecological systems, we predicted the expected fish community at a site $\sim 75 \%$ of the time, although we could not predict the quality or biointegrity of the community without local habitat information. This discounted sites that we predicted would have a fish community, but were dry or fishless. Predicted fish communities associated with the mapped ecological type versus the actual community sampled is presented in Appendix B. The Cottonwood Creek Watershed contained the most sites with a reference type fish community for a small Northern Glaciated Stream Fish Community (AES type C006) and the Frenchman Creek Watershed contained the most sites with a reference condition Medium Great Plains Prairie River (B006). Unless degraded by anthropogenic impairments, as in the case of the mainstem Cottonwood Creek, we predicted the confluence area fish communities quite reliably.

\section{Applications for Water Quality Assessment}

For one example of the utility of the classification system, we present a comparison of the observed/ expected $(\mathrm{O} / \mathrm{E})$ classified fish community against the Index of Biotic Integrity (IBI) from the Little Missouri River in Table 7. An initial examination of the data shows that two species ( 1 tolerant generalist) are lost from the 2001 sample and 3 (2 native intolerants and a tolerant non-native) species are gained in 2003 for a net gain of one for total fish species richness in the 2003 sample. 
Table 7. Fish data from the Little Missouri River (A003) showing yearly temporal variability of samples taken 2 years apart during the same month in the same river reach

\begin{tabular}{lcc}
\hline Taxon & $\mathbf{2 0 0 1}$ & $\mathbf{2 0 0 3}$ \\
\hline Channel Catfish & 28 & 12 \\
Common Carp & 4 & 3 \\
Goldeye & 2 & 1 \\
Longnose Dace & 0 & 5 \\
Flathead Chub & 0 & 22 \\
Sand Shiner & 30 & 537 \\
Fathead Minnow & 6 & 71 \\
River Carpsucker & 3 & 53 \\
White Sucker & 5 & 16 \\
Shorthead Redhorse & 9 & 1 \\
Stonecat & 5 & 2 \\
Black Bullhead & 0 & 119 \\
Green Sunfish & 7 & 0 \\
Plains Minnow & 3 & 0 \\
Creek Chub & 0 & 0 \\
Total Species & $\mathbf{1 1}$ & $\mathbf{1 2}$ \\
Fish IBI* & $\mathbf{7 8}$ & $\mathbf{8 2}$ \\
O/E*^ & $\mathbf{6 9 . 2}$ & $\mathbf{7 6 . 9}$ \\
* Best possible score is 100. & \\
^ Observed native species/Expected native \\
species for the community (Appendix F.)
\end{tabular}

The Fish IBI (Bramblett et al. 2003) increases slightly between years, but stays in the same ranking category (Good condition; minimally impacted). Although, the appearance of the flathead chub and longnose dace, and an increase in the numbers of sand shiners and river carpsuckers reveals much more information about the 2003 sample than the IBI conveys. Without being at the site, we can conclude from the additional indicator species of community A003, especially the longnose dace from SPA \#20 and the flathead chub from SPA \#2, that increased flows were present during the time of the fish sample in 2003, and have made available more riffle habitat and gravel substrate. The $\mathrm{O} / \mathrm{E}$ value increases nearly 8 percentage points against the IBI's 4 points, indicating an improvement towards a fully intact community $(\mathrm{O} / \mathrm{E}=1$ or $100 \%)$. The interesting thing about the $\mathrm{O} / \mathrm{E}$ is that it is a much simpler calculation than the IBI, and comes closer to representing the nature of what's going on in the stream (without knowing the cutoffs for the impaired-unimpaired, or as we will refer to a fullyfunctional vs. non-intact community).

For an example of the utility of the classification system for the macroinvertebrate communities, we offer a comparison of a hypothetical 300-count macroinvertebrate sample containing all indicator species of the Prairie Stream Assemblage with the number of specimens identified. If we assign the designated tolerance levels associated with the DEQ protocols (DEQ 2005), four of the species in the sample (box): Caenis latipennis, Dubiraphia, Physella, and Psectrocladius are listed as tolerant, and the \% tolerant taxa metric in the Foothills Valleys and Plains IBI would be $70 \%$ (215/305) which is $>35 \%$ or a zero score.

\begin{tabular}{|ll|}
\hline Caenis latipennis & 120 \\
Ceratopogon & 10 \\
Coenagrion & 10 \\
Labrundinia & 5 \\
Dubiraphia & 25 \\
Enallagma civile & 10 \\
Physella & 55 \\
Enallagma sp. & 35 \\
Sigara alternata & 25 \\
Psectrocladius & 15 \\
\hline \hline Total & $\mathbf{3 0 5}$ \\
\hline
\end{tabular}

Although, if the MT DEQ and other agencies evaluated and considered the indicator species of the expected communities within the prairie stream ecosystems as inhabitants of an intact system, instead of tolerant organisms, the $\%$ tolerant taxa score would be much higher ( 3 is the best possible score) and bioassessments will become more meaningful. 


\section{Applications for Conservation and Management}

Numerous streams sampled within the pilot watersheds and the study area contained fully functional native communities, as defined by the biological classification (Table 8).

Within the Cottonwood Watershed in the Northern Glaciated Plains, Woody Island Coulee downstream of the Buckley Creek confluence (WIC) contained the most intact fish community that watershed with an almost complete assemblage of expected fish species from the C006 community (see Table 9).

Although only one species of the Northern Redbelly Dace Assemblage (\#4) was observed in the watershed, there seems to be the potential to harbor others (see table 5 or Appendix H). WIC has many miles of intact/minimally impacted stream reaches that flow within BLM managed lands with high biological integrity for both the fish and macroinvertebrate communities. One missing species from the watershed is the longnose dace, which is a little surprising because the adjacent

Table 8. Prairie Streams and Rivers within BLM lands that have documented (*) or have the potential to contain high quality aquatic communities

\begin{tabular}{lccc}
\hline Stream Name & $\begin{array}{c}\text { Northwestern } \\
\text { Great Plains }\end{array}$ & $\begin{array}{c}\text { Northern } \\
\text { Glaciated Plains }\end{array}$ & AES Type \\
\hline Assiniboine Creek* & & $\mathbf{X}$ & C006 \\
Bitter Creek & $\mathrm{X}$ & $\mathbf{X}$ & D006 \\
Boxelder Creek & & $\mathbf{X}$ & C005 \\
Frenchman Creek* & $\mathbf{X}$ & $\mathrm{X} 006$ \\
Garland Creek* & & $\mathbf{X}$ & $\mathrm{D} 006$ \\
Little Powder River* & $\mathbf{X}$ & $\mathrm{B} 005$ \\
Little Sandy Creek* & $\mathbf{X}$ & $\mathbf{X}$ & $\mathrm{D} 006$ \\
Murray Coulee* & & $\mathbf{X}$ & $\mathrm{D} 006$ \\
Powder River* & $\mathbf{X}$ & $\mathrm{C} 006$ \\
Rock Creek* & & $\mathbf{X}$ & $\mathrm{C} 006$ \\
West Fork Poplar & & & $\mathrm{C} 006$ \\
Woody Island Coulee* & & & \\
\hline
\end{tabular}

Table 9. Observed fish communities from sites sampled in selected Northern Glaciated C006 Streams. WIC $=$ Woody Island Coulee

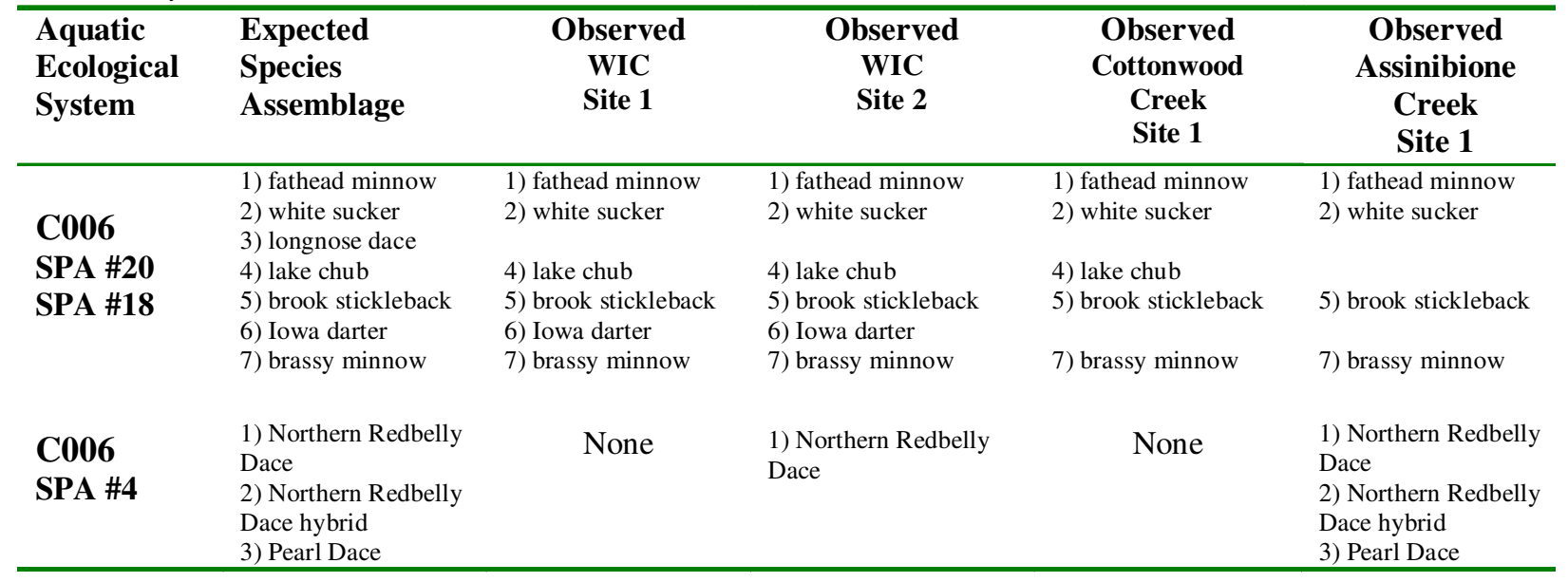


watersheds such as Battle Creek, and Frenchman Creek report longnose dace when riffle habitats are sampled.

Murray Coulee, a tributary to Woody Island Coulee, has the best potential of the D006 stream types to maintain a fully intact fish community, mostly due to the downstream connection to WIC and an un-impacted 10 mile reach before its confluence. Assiniboine Creek, a sub-watershed just south of the Cottonwood watershed, contained a full complement of SPA \#4 species and contains the Montana Species of Concern and BLM sensitive species: Northern Redbelly Dace hybrid and the Pearl Dace.

Garland Creek is a tributary of Cottonwood Creek at RM 13.4 and was reported to contain the Northern Redbelly Dace hybrid (Montana Species of Concern and BLM sensitive species) in 1979, but has not been reported again. This site may be worth revisiting to verify the presence of this Redbelly Dace Assemblage member and possibly inventory other species in this group.
At the broader landscape level, within the Frenchman Creek watershed, large areas of BLM managed badlands above the Frenchman Creek Reservoir were designated as important conservation priorities by Cooper et al. 2001 and by the Nature Conservancy's Northern Glaciated Plains Ecoregional Plan (Figure 47).

Although Cooper et al. (2001) described the outstanding terrestrial communities of this region; they didn't report fish communities in this study. Subsequent fish sampling in the Frenchman Creek area have confirmed that there is also an intact medium prairie stream community for this B006 system, including the Iowa darter, plains minnow and the stonecat (3 fish species under review as Montana Species of Concern). If this correlation of intact, fully functioning landscapes and fish communities holds within other glaciated plains sites, then the other priority landscape areas of upper Rock, Crow, Bitter and Buggy Creeks should be investigated for intact fish communities and possible sensitive species. 
Figure 47. The Nature Conservancy's Priority Northern Glaciated landscapes (taken from Cooper et. al. 2001)

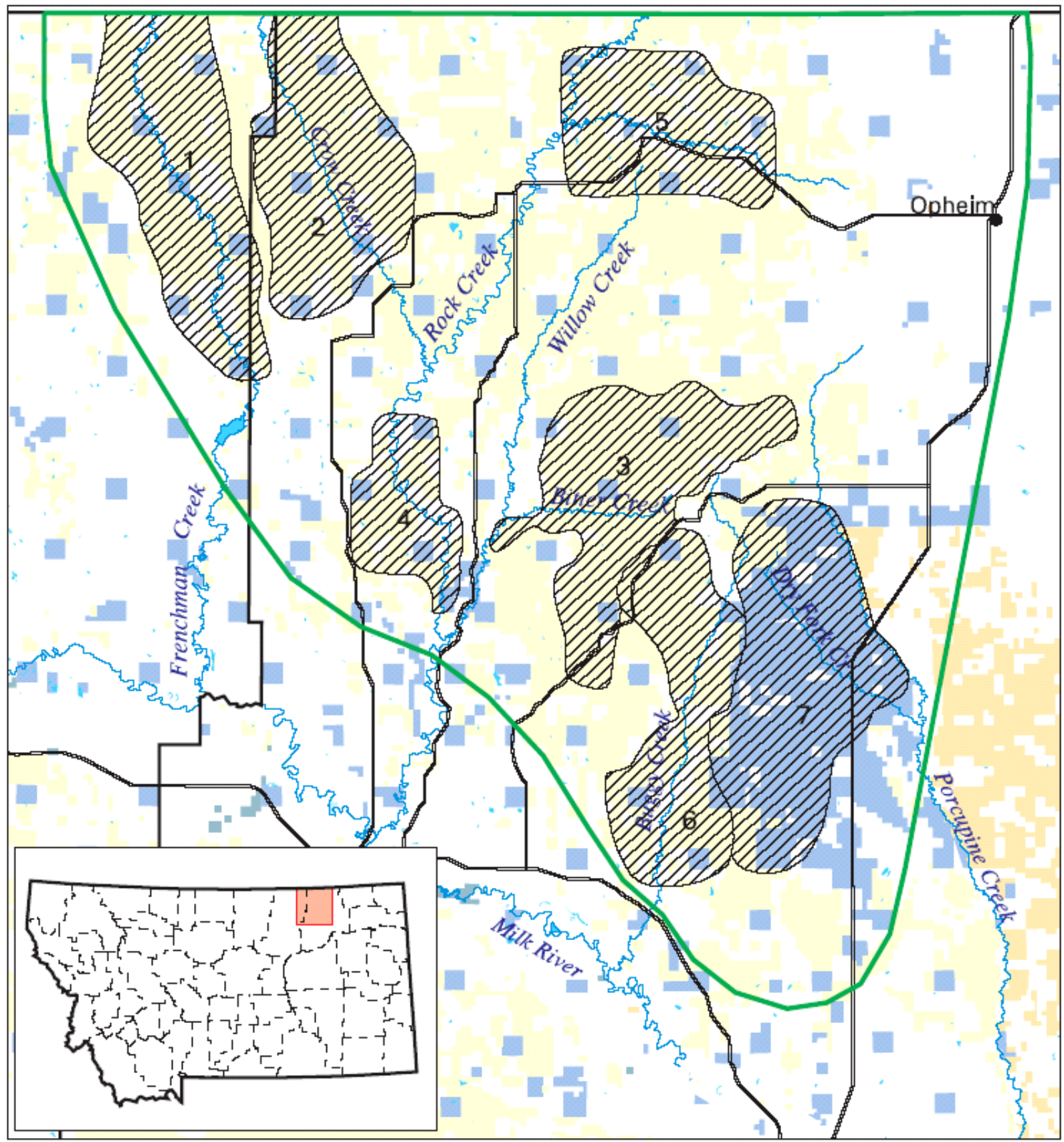

1 Frenchman Creek Landscape

2 Crow Creek Landscape

3 Bitter Creek Badlands Landscape

4 Rock Creek Canyon Landscape

5 South Fork Rock Creek Landscape

6 Buggy Creek Landscape

7 Dry Fork Creek Landscape

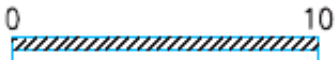

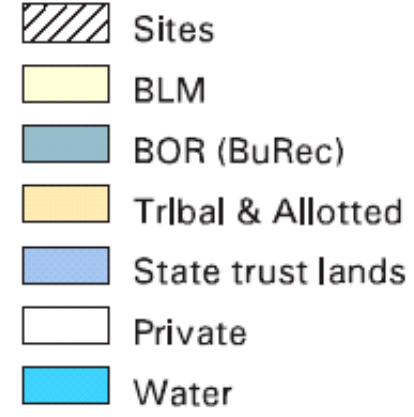

Miles 


\section{Conclusions \& ReCOMmENDATIONS}

This project establishes a data-based classification system for Montana's streams and rivers and their associated biological communities at the Aquatic Ecological System (AES) scale for the Upper Missouri Zoogeographic Region. We believe that the physical gradients delineated in our analyses will be useful as abiotic variables in predictive models of biotic communities for watersheds in the Missouri drainages of Montana. This classification is most useful for watershed management and conservation at the AES level, since the finest scale, the macrohabitat level is variable and often more dependent on local factors. This conclusion follows other studies that have shown local reachscale habitat features often "trump" landscape factors in determining stream community structure (Allen et al. 1997, Lyons 1996). Clearly, understanding the reach-scale determinants of community structure, and being "on the ground" has important merit for elucidating lower levels of the classification and for fine-scale stream restoration or conservation projects.

This biological classification of aquatic systems has identified expected native fish communities for aquatic ecological systems, as well as fish species assemblages that reflect a stream's connectivity to different water bodies, geomorpholgy or habitat condition. This predictive capability to identify expected reference communities establishes biological based goals for watershed restoration and benchmarks for monitoring programs. The macroinvertebrate groups are more variable, especially for the prairie streams and at this point, do not support identification of impaired or reference sites. Although, if the MT DEQ and other agencies evaluated the indicator species of the expected communities within the prairie stream ecosystems as inhabitants of an intact system, instead of tolerant organisms, bioassessments will become more meaningful. Further work with macroinvertebrate communities at a finer scale (damselflies and Corixidae at the species level) and with the "expected community" concept in mind may prove useful for watershed assessments.

Transitional environmental conditions exist and within these "grey areas" species overlap and community intergrades will occur; finding ways to address these within the classification is challenging and will involve additional work. Further assessing statewide distribution patterns of identified biotic communities within Aquatic Ecological Systems will be useful in confirming the key abiotic variables and will thereby increase the robustness of the classification's predictive capabilities.

We identified 10 priority areas in the basin for prairie stream aquatic biodiversity. Several of these sites fall within BLM-managed areas that contain fully intact aquatic biological communities and sensitive species, as well as sites with the potential to harbor communities containing sensitive species. These high quality communities could be maintained by minimizing or mitigating impacts from surrounding land use practices (e.g. Grazing, mining, road building, etc.), and avoiding any intentional or unintentional fish stocking. The best approach to conserving aquatic species and systems will be to ensure that habitats are managed in ways that maintain healthy ecosystems and allow the full complement of native species to flourish

Effective conservation of aquatic resources requires a system for identifying high quality aquatic systems and communities and understanding the habitat conditions that support them. The classification system has delivered the first evaluation of the diversity of aquatic ecosystems in the Missouri River drainages of Montana. With additional funding from partners, the potential future goals of the aquatic ecosystem classification will be to:

- Identify, rank and track aquatic ecosystem types and their communities across the state and within all ecoregions.

- Further evaluate macroinvertebrate communities and their value in the classification.

- Identify as many reference condition sites of all aquatic ecosystem types and their relationship to management practices and riparian assessments. 


\section{Literature Cited}

Abell, R.A., D. M. Olson, E. Dinerstein and Patrick Hurley, eds. 2000. Freshwater Ecoregions of North America: A Conservation Assessment. World Wildlife Fund-US. Island Press, Washington, D.C.

Allen, J.D., D.L. Erickson, and J. Fay. 1997. The influence of catchment land-use on stream integrity across multiple scales. Freshwater Biology 37: 149-161.

Allen, J.D. 1995. Stream Ecology: Structure and Function of Running Waters. Chapman and Hall. Boundary Row, London, UK.

Angermeier, P.L., and I.J. Schlosser. 1989. Species-area relationships for stream fishes. Ecology. 70: 1450-1462.

Angermeier, P. L. and I. J. Schlosser. 1995. Conserving aquatic biodiversity: Beyond species and populations. American Fisheries Society Symposium 17: 402-414.

Barbour, M.T., Gerritsen, J.,Snyder, B.D., and J.B Stribling. 1999. Rapid bioassessment protocols for use in streams and wadeable rivers: periphyton, benthic macroinvertebrates, and fish. Second edition. U.S. Environmental Protection Agency, Office of Water, Washington, D.C. EPA 841-B99-002.

Bramblett, R. G., T. R. Johnson, A. V. Zale, A. V., and D. Heggem. 2003. Development of Biotic Integrity Indices for Prairie Streams in Montana Using Fish, Macroinvertebrate, and Diatom Assemblages. Final Report to the EPA.

Bramblett, R. G., and K. D. Fausch. 1991. Variable fish communities and the index of biotic integrity in a western Great Plains river. Transactions of the American Fisheries Society 120:752-769.

Bukantis, B. 1998. Rapid bioassessment macroinvertebrate protocols: sampling and sample analysis SOP's. Montana Department of Environmental Quality. Helena MT
Caton, L.W. 1991. Improving subsampling methods for the EPA "Rapid Bioassessment" benthic protocols. Bulletin of the North American Benthological Society. 8(3): 317-319.

Chutter, F.M. 1969. The effects of silt and sand on the invertebrate fauna of streams and rivers. Hydrobiologia 34: 57-76.

Cooper, S.V. et al. 2001. Biological Survey of the Prairie Landscape in Montana's Glaciated Plains. Report to the BLM. Montana Natural Heritage Program, Helena, MT 24pp + appendicies.

Cross, F. B., and R. E. Moss. 1987. Historic changes in fish communities and aquatic habitats in plains streams of Kansas. Pages 155-165 in W. J. Matthews and D. C. Heins, editors. Community and evolutionary ecology of North American stream fishes. University of Oklahoma Press, Norman.

DEQ. 2005. Sample Collection, Sorting, and Taxonomic Identification of Benthic Macroinvertebrates. Montana Department of Environmental Quality Water Quality Planning Bureau Standard Operating Procedure WQPBWQM-009. April 2005.

Dodds, W. K., K. Gido, M. R. Whiles, K. M. Fritz, and W. J. Matthews. 2004. Life on the edge: The ecology of Great Plains prairie streams. BioScience 54: 205-216.

Dufrene, M. and P. Legendre. 1997. Species assemblages and indicator species: the need for a flexible asymmetrical approach. Ecological Monographs. 67: 345-366.

Feminella, J.W. 2000. Correspondence between stream macroinvertebrate assemblages and 4 ecoregions of the southeastern USA. Journal of the North American Benthological Society. 19(3): 442-461. 
FWP MFISH 2004. Montana State Library, Natural Resources Information System. Montana Fish, Wildlife, and Parks Fish Stocking Records database, 2000; Montana Rivers Information System fish presence database, 2004; Helena, MT.

Gauch, H.G., Jr. 1982. Multivariate Analysis in Community Ecology. Cambridge University Press, New York, New York.

Gregory, S.V., Swanson, F.J., McKee, W.A., and K.W Cummins. 1991. An ecosystem perspective of riparian zones: Focus on links between land and water. BioScience. 41: 540-551.

Groves, C., et al. 2002. Planning for biodiversity conservation: putting conservation science into practice. Bioscience 52: 499-512.

Gustafson, D. Entomologist, Montana State University, Bozeman, MT. Personal communication. May 2004.

Hawkins, C.P., Hogue, J.N., Decker, L.M., and J.W. Feminella. 1997. Channel morphology, water temperature, and assemblage structure of stream insects. Journal of the North American Benthological Society 16: 728-749.

Hawkins, C. P. and R. H. Norris. 2000. Performance of different landscape classifications for aquatic bioassessments: introduction to the series. Journal of the North American Benthological Society.19:3 (367-369).

Hawkins, C. P. and M. R Vinson. 2000. Weak correspondence between landscape classifications and stream invertebrate assemblages: implications for bioassessment. Journal of the North American Benthological Society. 19: 3 (501-517).

Hawkins, C.P., Norris, R.H., Gerritsen, J., Hughes, R.M., Jackson, S.K., Johnson, R.K., and R.J. Stevenson. 2000. Evaluation of the use of landscape classifications for the prediction of freshwater biota: synthesis and recommendations. Journal of the North American Benthological Society 19(3): 541-556.
Hewlett, R. 2000. Implications of taxonomic resolution and sample habitat for stream classification at a broad geographic scale. J. N. Am . Benthol. Soc. 19(2): 352-361.

Higgins, J., M. M. Bryer, M. Khoury and T. W. Fitzhugh. 2005. A Freshwater Classification Approach for Biodiversity Conservation Planning. Conservation Biology 19 (2): 432-445.

Higgins, J., M. Lammert, M. Bryer, M. DePhilip, and D. Grossman. 1998. Freshwater Conservation in the Great Lakes Basin: Development and application of an aquatic Community classification framework. The Nature Conservancy, Chicago, IL.

Holton, G. D., and H. E. Johnson. 2003. A field guide to Montana fishes, 3rd edition. Montana Fish, Wildlife, and Parks, Helena.

Hughes, R. M., P. R. Kaufmann, A. T. Herlihy, T. M. Kincaid, L. Reynolds, and D. P. Larsen. 1998. A process for developing and evaluating indices of fish assemblage integrity. Canadian Journal of Fisheries and Aquatic Sciences 55:1618-1631.

Jones, W. M. 2003. Milk and Lower Marias River Watersheds: Assessing and Maintaining the Health of Wetland Communities. Report to the Bureau of Reclamation. Montana Natural Heritage Program, Helena. 17 pp. plus appendices.

Kessler, R.K., Casper, A.F., and G.K. Weddle. 1995. Temporal variation in microhabitat use and spatial relations in the benthic fish community of a stream. American Midland Naturalist 134: 361-370.

Krebs, C.J. 1985. Ecology: the experimental analysis of distribution and abundance. Third edition. Harper Collins Publishers, New York, USA. $x v+800$ pp.

Kruskal, J.B. and M. Wish. 1978. Multidimensional Scaling. Sage Publications, Beverly Hills, California, USA. 
Lazorchak, J.M., Klemm, D.J., and D.V. Peck (editors). 1998. Environmental Monitoring and Assessment Program - Surface Waters: Field Operations and Methods for Measuring the Ecological Condition of Wadeable Streams. EPA/620/R-94/004F. U.S. Environmental Protection Agency, Washington, D.C.

Lenat, D.R. and J.K. Crawford. 1994. Effects of land use on water quality and aquatic biota of three North Carolina Piedmont streams. Hydrobiologia 294: 185-199.

Lyons, J. 1989. Correspondence between the distribution of fish assemblages in Wisconsin streams and Omernik's ecoregions. American Midland Naturalist 122: 163-182.

Lyons, J. 1996. Patterns in the species composition of fish assemblages among Wisconsin streams. Environmental Biology of Fishes 45: 329-41.

Marchant, R. 1990. Robustness of classification and ordination techniques applied to macroinvertebrate communities from the La Trobe River, Victoria. Australian Journal of Marine and Freshwater Research. 41: 493-504.

Marchant, R. 1994. Preliminary study of the ordination and classification of macroinvertebrate communities from running waters in Victoria, Australia. Australian Journal of Marine and Freshwater Research. 45: 945-62.

Marshall, B.D. and B.L. Kerans. 2003. A Critical Appraisal of Montana's Rapid bioassessment Protocals (MT RBP) for Evaluating the Ecological Condition Streams and Rivers Using Benthic Macroinvertebrates. Montana State University. Report to Department of Environmental Quality.

Master, L.L., Stein, B.A., Kutner, L.S., and G.A , Hammerson, 1998. Vanishing assets: conservation status of U.S. species. In Precious Heritage: the status of biodiversity in the United States. Edited by Stein, B.A., Kutner, L.S., Adams, J.S. Oxford University Press, New York, New York, USA. pp 93-118.
Matthews, W.J. and H.W. Robison. 1998. Influence of drainage connectivity, drainage area, and regional species richness on fishes of the Interior Highlands in Arkansas. American Midland Naturalist. 139: 1-19.

McCormick, F.H., Peck, D.V., and D.P. Larsen. 2000. Comparison of geographic Classification schemes for the Mid-Atlantic stream fish assemblages. Journal of the North American Benthological Society. 19(3): 385-404.

McCune, B. 1997. Influence of noisy environmental data on canonical correspondence analysis. Ecology. 78: 2617-2623.

McCune, B. and J.B. Grace. 2002. Analysis of Ecological Communities. MjM Software Design, Gleneden Beach, Oregon, USA.

McCune, B., and M.J. Mefford. 2002. PC-ORD. Multivariate Analysis of Ecological Data, Version 4. MjM Software Design, Gleneden Beach, Oregon, USA.

Meador, M.R., Hupp, C.R., Cuffney, T.F., and M.E Gurtz. 1993. Methods for characterizing stream habitat as part of the national water quality assessment program. U.S. Geological Survey Open File Report. Raleigh, N.C. USGS/OFR 93408.

Merritt, K.W. and K.W. Cummins. 1996. An Introduction to the Aquatic Insects of North America. Third edition. Kendall/Hunt Publishing Co., Dubuque, Iowa, USA. 43-45pp.

Minshall, G.W., Cummins, K.W., Petersen, R.C., Cushing, C.E., Bruns, D.A., Sedell, J.R., and R.L Vannote. 1985. Developments in Stream Ecosystem Theory. Canadian Journal of Fisheries and Aquatic Sciences 42: 1045-1055.

MTDEQ. 2005. Sample Collection, Sorting, and Taxonomic Identification of Benthic Macroinvertebrates. Montana Department of Environmental Quality Water Quality Planning Bureau Standard Operating Procedure WQPBWQM-009. April 2005. 
Myers, M. 1995. Aquatic Insects in the Springs of the Great Basin. Department of Environmental Science, Policy and Management, UC Berkeley.

Nesser et. al. 1997. Ecological Units of the Northern Region: Subsections. USDA Forest Service Intermountain Research Report: INTGTR-369. 88pp.

Nightingale, B., M. Walsh, R. Evans, D. Homans and E. Bond 2003. The Pennsylvania Aquatic Community Classification Project. The Pennsylvania Natural Heritage Program. 219 pp.

NRIS. 2004. Natural Resources Information System, Digital Atlas of Montana, Helena, MT (http://maps2.nris.state.mt.us/mapper/watershed/ watershed.html). Accessed June 2004.

Omernik, J.M. 1995. Ecoregions: A Spatial Framework for Environmental Management. Chapter 5. Davis, W. and T. Simon, eds. Pages 49-64 in Biological Assessment and Criteria: tools for water resource planning and decision making. Lewis Publishers, Boca Raton, London.

Peterson, J.T. and C.F. Rabeni. 2001. The relation of fish assemblages to channel units in an Ozark stream. Transactions of the American Fisheries Society 130: 911-926.

Plafkin, J.L., Barbour, M.T., Porter, K.D., Gross, S.K., and R.M. Hughes. 1989. Rapid bioassessment protocols for use in streams and rivers: Benthic macroinvertebrates and fish. U.S. Environmental Protection Agency, Office of Water Regulations and Standards, Washington, D.C. EPA 440-4-89-001.

Pflieger, W. L. 1997. The fishes of Missouri, revised edition. Missouri Department of Conservation, Jefferson City.

Rabeni, C.F. and K.E Doisy. 2000. Correspondence of stream benthic invertebrate assemblages to regional classification schemes in Missouri. Journal of the North American Benthological Society. 19(3): 419-428.
Rahel, F. J. 2000. Homogenization of fish faunas across the United States. Science 288:854-856.

Rahel, F. J. 2002. Homogenization of freshwater faunas. Annual Review of Ecology and Systematics 33:291-315.

Rehwinkel, B.J. 1978. Montana Department of Fish and Game: Powder River Aquatic Ecology Project. Final Report 1975-8. Utah International Inc.119 pp.

Ricciardi, A., and J.B. Rasmussen. 1999. Extinction rates of North American freshwater fauna. Conservation Biology 13(5): 1220-1222.

Richter, B.D., D.P. Braun, M. A. Mendelson, and L.L. Master. 1997. Threats to imperiled freshwater fauna. Conservation Biology 11:10811093.

Richards, C., Haro, R.J., Johnson, L.B., and G.E Host. 1997. Catchment and reach-scale properties as indicators of macroinvertebrate species traits. Freshwater Bio 37: 219-230.

Rosgen, D.L. 1996. A Classification of Natural Rivers. Catena, Vol. 22: 169-199. Elsevier Science, B.V. Amsterdam.

Scott, W. B., and E. J. Crossman. 1973. Freshwater fishes of Canada. Fisheries Research Board of Canada, Bulletin 184, Ottawa.

Stagliano, D.M. 2004. A Biological Assessment of Sites in the Custer National Forest (Ashland Ranger District) using Aquatic Macroinvertebrates. Report to the Custer National Forest Ashland District. 24 pp.

Stagliano, D.M., and M.R. Whiles. 2002. Macroinvertebrate production and trophic structure in a tallgrass prairie headwater stream. Journal of North American Benthological Society 21(1): 97-113.

Strahler, A. N. 1957. Quantitative analysis of watershed geomorphology. Transactions of the American Geophysical Union 38:913-920. 
Stein, B.A., Kutner, L.S., Hammerson, G.A., Master, L.A., and L.E Morse,. State of the states: geographic patterns of diversity, rarity, and endemism. In Precious Heritage: the status of biodiversity in the United States. Edited by Stein, B.A., Kutner, L.S., Adams, J.S. Oxford University Press, New York, New York, USA. 93-118pp.

Suplee, M. 2004. Wadeable streams of Montana's Hi-line region: an analysis of their nature and condition, with an emphasis on factors affecting aquatic plant communities and recommendations to prevent nuisance algae conditions. Montana DEQ, May 2004. http://www.deq.state.mt.us/ wqinfo/Standards/Master_Doc_DII.pdf

TetraTech Inc. 2000. TetraTech, Inc. Fairfax, Virginia, USA.

The Nature Conservancy. 1999. Seeing the forest and the trees: Ecological Classification for Conservation. The Nature Conservancy, Arlington, Virginia.

Turak, E., Flack, L.K., Norris, R.H., Simpson, J., Waddell, N. 1999. Assessment of river condition at a large spatial scale using predictive models. Freshwater Biology. 41:283-298.

United States Geological Survey (USGS). 2004. http://infolink.cr.usgs.gov/The_River/Accessed June 2004.

Vannote, R.L., Minshall, G.W., Cummins, K.W., Sedell, J.R., and C.E Cushing. 1980. The river continuum concept. Canadian Journal of Fisheries and Aquatic Sciences 37: 130-137.

Waite, I. R., A.T. Herlihy, D. P. Larsen and D. J. Klemm. 2000. Comparing strengths of geographic and nongeographic classifications of stream benthic macroinvertebrates in the MidAtlantic Highlands, USA. J. N. Am. Benthol. Soc. 19(3):429-441.
Weigel, B.M., Wang, L.Z., Rasmussen, P.W., Butcher, J.T., Stewart, P.M., Simon, T.P., and M.J. Wiley. 2003. Relative influence of variables at multiple spatial scales on stream macroinvertebrates in the Northern Lakes and Forest ecoregion, USA. Freshwater Biology 48(8): 1440-1461.

Wehrly, K. E. M.J. Wiley and P.W. Seelbach. 1998. A thermal habitat classification for lower Michigan rivers. MI Dept. of Natural Resources Fisheries research report No. 2038.

Whittaker, R.H. 1962. Classification of natural communities. Botanical Review. 28:1-239.

Winston, M. R., C. M. Taylor, and J. Pigg. 1991. Upstream extirpation of four minnow species due to damming of a prairie stream. Transactions of the American Fisheries Society 120:98-105.

Wright, J. F., J.H. Blackburn, R.J.M. Gunn, M.T. Furse, P.D. Armatage, J.M. Winder, and K.L. Symes. 1996. Macroinvertebrate frequency data for the RIVPACS III and their use in conservation evaluation. Aquatic Conservation: Marine and Freshwater Ecosystems 6: 141-167.

Wright, J. F., M. T. Furse, and D. Moss. 1998. River classification using invertebrates: RIVPACS applications. Aquatic Conservation: Marine and Freshwater Ecosystems 8: 617-631.

Zelt, R. B., G. K. Boughton, K. A. Miller, J. P. Mason, and L. M. Gianakos. 1999. Environmental Setting of the Yellowstone River Basin, Montana, North Dakota, and Wyoming. USGS Water-Resources Investigations Report 98-4269.

Zorn, T.G, P.W. Seelbach and M. J. Wiley. 1998. Patterns in the distribution of stream fishes in Michigan's Lower Peninsula. Michigan Department of Natural Resources Fisheries Research Report No. 2035. 



\section{Appendix A. Information on Aquatic Ecological Systems, THEIR OCCURRENCES IN WATERSHEDS, CHARACTERISTICS, AND GEO- LOGIC FEATURES}





\begin{tabular}{|c|c|c|c|c|c|c|c|c|}
\hline $\begin{array}{l}\text { AES } \\
\text { Code }^{1}\end{array}$ & Description $^{2}$ & Size Class $^{3}$ & $\begin{array}{c}\text { Elevation } \\
\text { Class }^{4}\end{array}$ & $\begin{array}{l}\text { Geology } \\
\text { Code }^{5}\end{array}$ & $\begin{array}{l}\text { Geology } \\
\text { Class }\end{array}$ & $\begin{array}{c}\text { River } \\
\text { Representative }^{7}\end{array}$ & $\begin{array}{c}\text { River } \\
\text { Origin }^{8}\end{array}$ & $\begin{array}{c}\text { Headwater } \\
\text { Gradient Class }^{9}\end{array}$ \\
\hline A001 & $\begin{array}{l}\text { Large valley river systems, origins in } \\
\text { Intermontane basins }\end{array}$ & large river & $\begin{array}{l}\text { low, } \\
\text { moderate }\end{array}$ & 331Df & $\begin{array}{l}\text { Alluvium, } \\
\text { glacial till, } \\
\text { volcanic } \\
\text { deposits }\end{array}$ & Missouri River & $\begin{array}{l}\text { Beaverhead Mountains, } \\
\text { Yellowstone Highlands }\end{array}$ & moderate/high \\
\hline A002 & $\begin{array}{l}\text { Large valley river systems, origins in } \\
\text { intermontane basins }\end{array}$ & large river & $\begin{array}{l}\text { low, } \\
\text { moderate }\end{array}$ & $331 G$ & $\begin{array}{l}\text { Alluvium, } \\
\text { volcanic } \\
\text { deposits, } \\
\text { gneiss/shist }\end{array}$ & Yellowstone River & Yellowstone Highlands & moderate/high \\
\hline A003 & $\begin{array}{l}\text { Large prairie river, origins } \\
\text { Northwestern Great Plains and foothills }\end{array}$ & large river & low & $331 G$ & $\begin{array}{l}\text { sedimentary } \\
\text { alluvium }\end{array}$ & $\begin{array}{l}\text { Powder, Little } \\
\text { Missouri }\end{array}$ & $\begin{array}{l}\text { Sedimentary High } \\
\text { plains }\end{array}$ & low, moderate \\
\hline A004 & $\begin{array}{l}\text { Large prairie river, origins in the } \\
\text { Northern Glaciated Plains and foothills }\end{array}$ & large river & low & 331Dh & $\begin{array}{l}\text { alluvium, } \\
\text { sedimentary }\end{array}$ & Milk, Marias & $\begin{array}{l}\text { Montana Northwestern } \\
\text { Glaciated Plains }\end{array}$ & low, moderate \\
\hline B001 & $\begin{array}{l}\text { Medium intermontane rivers, origins in } \\
\text { intermontane basins within the } \\
\text { Southwest Montana Basin and Valley }\end{array}$ & $\begin{array}{l}\text { medium } \\
\text { river }\end{array}$ & moderate & M332Ej & $\begin{array}{l}\text { Alluvium, } \\
\text { glacial till, } \\
\text { volcanic } \\
\text { deposits }\end{array}$ & \begin{tabular}{|c|} 
Big Hole, \\
Beaverhead, \\
Madison, Jefferson, \\
Red Rock
\end{tabular} & $\begin{array}{l}\text { Yellowstone Highlands, } \\
\text { Beaverhead Mountains }\end{array}$ & moderate/high \\
\hline B002 & $\begin{array}{l}\text { Medium Intermontane rivers, origins in } \\
\text { Intermontane basins within the } \\
\text { Yellowstone Highlands }\end{array}$ & $\begin{array}{l}\text { medium } \\
\text { river }\end{array}$ & moderate & M331A & $\begin{array}{l}\text { Alluvium, } \\
\text { glacial till, } \\
\text { volcanic } \\
\text { deposits }\end{array}$ & Gallatin, Boulder, & Yellowstone Highlands & moderate/high \\
\hline B003 & $\begin{array}{l}\text { Medium Transitional/Foothill rivers, } \\
\text { origins in Isolated Mountain Ranges }\end{array}$ & $\begin{array}{l}\text { medium } \\
\text { river }\end{array}$ & $\begin{array}{l}\text { low, } \\
\text { moderate }\end{array}$ & M332Db & $\begin{array}{c}\text { Igneous/ } \\
\text { volcanic, } \\
\text { sandstone, shale } \\
\text { to limestone }\end{array}$ & \begin{tabular}{|l|} 
Judith, Stillwater, \\
Musselshell, Smith
\end{tabular} & $\begin{array}{l}\text { Isoloated Mountain } \\
\text { Ranges (Big Belts, } \\
\text { Judiths) }\end{array}$ & moderate/high \\
\hline В004 & $\begin{array}{l}\text { Medium Transitional/Foothils rivers, } \\
\text { origins in Rocky Mountain Front }\end{array}$ & $\begin{array}{l}\text { medium } \\
\text { river }\end{array}$ & $\begin{array}{l}\text { low, } \\
\text { moderate }\end{array}$ & 331Da & $\begin{array}{c}\text { Sandstone, shale } \\
\text { to limestone }\end{array}$ & Sun, Teton & Rocky Mountain Front & moderate/high \\
\hline В005 & $\begin{array}{l}\text { Medium Prairie rivers, origins in the } \\
\text { Northwestern Great plains and foothills }\end{array}$ & $\begin{array}{l}\text { medium } \\
\text { river }\end{array}$ & low & $331 G$ & sedimentary & O'Fallon, Boxelder & $\begin{array}{l}\text { Sedimentary High } \\
\text { plains }\end{array}$ & low, moderate \\
\hline
\end{tabular}




\begin{tabular}{|c|c|c|c|c|c|c|c|c|}
\hline $\begin{array}{l}\text { AES } \\
\text { Code }\end{array}$ & Description & Size Class & $\begin{array}{c}\text { Elevation } \\
\text { Class }\end{array}$ & $\begin{array}{c}\text { Geology } \\
\text { Code }\end{array}$ & Geology Class & $\begin{array}{c}\text { River } \\
\text { Representative }\end{array}$ & $\begin{array}{l}\text { River } \\
\text { Origin }\end{array}$ & $\begin{array}{l}\text { HW Gradient } \\
\text { Class }\end{array}$ \\
\hline B006 & $\begin{array}{l}\text { Medium Prairie rivers, origins in the } \\
\text { Northwestern Glaciated plains }\end{array}$ & $\begin{array}{l}\text { medium } \\
\text { river }\end{array}$ & low & 331Dh & $\begin{array}{l}\text { alluvium, } \\
\text { sedimentary }\end{array}$ & \begin{tabular}{c|} 
Cottonwood, \\
Frenchman Creek
\end{tabular} & $\begin{array}{c}\text { Montana Northwestern } \\
\text { Glaciated Plains }\end{array}$ & low, moderate \\
\hline B007 & $\begin{array}{l}\text { Medium Transitional/Foothill rivers, } \\
\text { flowing through Central Montana } \\
\text { Broad Valleys }\end{array}$ & $\begin{array}{l}\text { medium } \\
\text { river }\end{array}$ & $\begin{array}{l}\text { low, } \\
\text { moderate }\end{array}$ & M332Dk & Alluvium & $\begin{array}{l}\text { Missouri River, } \\
\text { Gallatin }\end{array}$ & $\begin{array}{c}\text { Yellowstone Highlands, } \\
\text { Beaverhead Mtns }\end{array}$ & moderate/high \\
\hline B008 & $\begin{array}{l}\text { Medium Prairie rivers, origins in the } \\
\text { Northern Glaciated plains and foothills }\end{array}$ & $\begin{array}{l}\text { medium } \\
\text { river }\end{array}$ & low & 331Ea & $\begin{array}{l}\text { alluvium, } \\
\text { sedimentary }\end{array}$ & Poplar River & $\begin{array}{l}\text { Montana Northern } \\
\text { Glaciated Plains }\end{array}$ & low, moderate \\
\hline C001 & $\begin{array}{l}\text { Small Foothills and Valley rivers, orgin } \\
\text { in foothills \& valley, sedimentary Mtns }\end{array}$ & small river & moderate & $\begin{array}{l}\text { 331Dc, } \\
\text { 331De }\end{array}$ & $\begin{array}{c}\text { Sandstone, } \\
\text { limestone, shales }\end{array}$ & Arrow, Dog, Pryor & $\begin{array}{c}\text { Montana Foothills and } \\
\text { Valleys } \\
\text { Bighorn Mountains }\end{array}$ & moderate \\
\hline C002 & $\begin{array}{l}\text { Small Montane/Foothills rivers, } \\
\text { Mod/Low Gradient in the Isolated Mts. }\end{array}$ & small river & moderate & $\begin{array}{l}\text { M332Dj } \\
\text { M332Dc }\end{array}$ & $\begin{array}{c}\text { Sandstone, } \\
\text { limestone, shales }\end{array}$ & $\begin{array}{c}\text { Belt Creek } \\
\text { Sweetgrass Creek }\end{array}$ & $\begin{array}{l}\text { Belt Mountains } \\
\text { Crazy Mountains }\end{array}$ & moderate/high \\
\hline C003 & $\begin{array}{l}\text { Small Montane/Foothills rivers, } \\
\text { Mod/Low Gradient }\end{array}$ & small river & moderate & M332Ej & Alluvium & $\begin{array}{l}\text { Bloody Dick } \\
\text { Creek, Horse } \\
\text { Prairie Creek }\end{array}$ & $\begin{array}{l}\text { Southwestern Montana } \\
\text { Foothills and Valleys }\end{array}$ & moderate/high \\
\hline C004 & $\begin{array}{l}\text { Small Montane/Foothills rivers, } \\
\text { Mod/Low Gradient }\end{array}$ & small river & moderate & M332Dj & Granite/volcanic & Boulder & $\begin{array}{l}\text { Middle Rockies, } \\
\text { Elkhorn Mtns. }\end{array}$ & moderate/high \\
\hline C005 & $\begin{array}{l}\text { Small Perennial Prairie rivers, origins } \\
\text { in the Northwestern Great plains and } \\
\text { foothills }\end{array}$ & small river & low & 331Ge & sedimentary & $\begin{array}{l}\text { Rosebud, Mizpah, } \\
\text { Otter }\end{array}$ & $\begin{array}{l}\text { Sedimentary High } \\
\text { plains }\end{array}$ & low, moderate \\
\hline C006 & $\begin{array}{l}\text { Small Perennial Prairie rivers, origins } \\
\text { in the Northwestern Glaciated plains } \\
\text { and foothills }\end{array}$ & small river & low & 331Dh & $\begin{array}{l}\text { alluvium, } \\
\text { sedimentary }\end{array}$ & $\begin{array}{l}\text { Sage, Battle, } \\
\text { Woody Island } \\
\text { Coulee }\end{array}$ & $\begin{array}{c}\text { Montana Northwestern } \\
\text { Glaciated Plains }\end{array}$ & low, moderate \\
\hline C007 & $\begin{array}{l}\text { Montane -Moderate/Low gradient } \\
\text { streams-YLH,BVH }\end{array}$ & small river & moderate & M332E & $\begin{array}{l}\text { Alluvium, } \\
\text { glacial till, } \\
\text { volcanic } \\
\text { deposits }\end{array}$ & Wise River, & $\begin{array}{l}\text { Yellowstone Highlands, } \\
\text { Beaverhead Mountains }\end{array}$ & high, moderate \\
\hline C008 & $\begin{array}{l}\text { Small Perennial Prairie rivers, origins } \\
\text { in the Northern Glaciated plains and } \\
\text { foothills }\end{array}$ & small river & low & 331Ea & $\begin{array}{l}\text { Alluvium, } \\
\text { sedimentary }\end{array}$ & $\begin{array}{l}\text { Butte Creek, West } \\
\text { Fork Poplar, Wolf } \\
\text { Creek }\end{array}$ & $\begin{array}{l}\text { Montana Northern } \\
\text { Glaciated Plains }\end{array}$ & low, mod \\
\hline D001 & $\begin{array}{l}\text { Headwater Foothills and Valley } \\
\text { streams, origin in foothills and valley }\end{array}$ & $\begin{array}{l}\text { headwater, } \\
\text { creek }\end{array}$ & moderate & M332Da & $\begin{array}{c}\text { Sandstone, } \\
\text { limestone, shales }\end{array}$ & $\begin{array}{l}\text { Elk and Yellow } \\
\text { Water Creeks } \\
\text { (tributaries to } \\
\text { Flatwillow Creek) }\end{array}$ & $\begin{array}{l}\text { Montana Foothills and } \\
\text { Valleys }\end{array}$ & moderate \\
\hline
\end{tabular}




\begin{tabular}{|c|c|c|c|c|c|c|c|c|}
\hline $\begin{array}{l}\text { AES } \\
\text { Code }\end{array}$ & Description & Size Class & $\begin{array}{c}\text { Elevation } \\
\text { Class }\end{array}$ & $\begin{array}{l}\text { Geology } \\
\text { Code }\end{array}$ & Geology Class & $\begin{array}{c}\text { River } \\
\text { Representative }\end{array}$ & $\begin{array}{l}\text { River } \\
\text { Origin }\end{array}$ & $\begin{array}{l}\text { HW Gradient } \\
\text { Class }\end{array}$ \\
\hline D002 & Montane -Moderate gradient streams & $\begin{array}{c}\text { headwater, } \\
\text { creek }\end{array}$ & moderate & $\begin{array}{l}\text { M332C, } \\
\text { M332Dh }\end{array}$ & $\begin{array}{c}\text { Sandstone, } \\
\text { limestone, shales }\end{array}$ & $\begin{array}{l}\text { North Fork of the } \\
\text { Sun, Tenderfoot, } \\
\text { Urvi Creek }\end{array}$ & $\begin{array}{l}\text { Rocky Mtn Front } \\
\text { Belt Mtns }\end{array}$ & high, moderate \\
\hline D003 & $\begin{array}{l}\text { Montane -Moderate gradient streams } \\
\text { origins in Isolated Mtn Ranges }\end{array}$ & $\begin{array}{c}\text { headwater, } \\
\text { creek }\end{array}$ & moderate & M332Ej & Alluvium & $\begin{array}{l}\text { Big Timber Creek } \\
\text { Deep Creek }\end{array}$ & $\begin{array}{c}\text { Crazy Mtns } \\
\text { Beaverhead Mtns }\end{array}$ & Moderate, high \\
\hline D004 & $\begin{array}{l}\text { Montane -Moderate gradient streams } \\
\text { origins in Granictic Mountain Ranges }\end{array}$ & $\begin{array}{l}\text { headwater, } \\
\text { creek }\end{array}$ & moderate & $\begin{array}{l}\text { M332Dj } \\
\text { M332Eg }\end{array}$ & Granite/volcanic & $\begin{array}{l}\text { Elkhorn Creek, } \\
\text { Lump Gulch, } \\
\text { Pintler Creek } \\
\text { Lemarche Creek }\end{array}$ & $\begin{array}{l}\text { Elkhorn Mtns } \\
\text { Anaconda Mtns }\end{array}$ & Moderate, high \\
\hline D005 & $\begin{array}{l}\text { Small Intermittent Prairie streams, } \\
\text { origins in the Northwestern Great } \\
\text { plains and foothills }\end{array}$ & $\begin{array}{c}\text { headwater, } \\
\text { creek }\end{array}$ & low/mod & $331 \mathrm{Ge}$ & sedimentary & $\begin{array}{l}\text { Lame Deer, E. } \\
\text { Fork Hanging } \\
\text { Woman } \\
\end{array}$ & $\begin{array}{l}\text { Sedimentary High } \\
\text { plains }\end{array}$ & low, mod \\
\hline D006 & $\begin{array}{l}\text { Small Intermittent Prairie streams, } \\
\text { origins in the Northern Glaciated plains } \\
\text { and foothills }\end{array}$ & $\begin{array}{l}\text { headwater, } \\
\text { creek }\end{array}$ & low/mod & 331Dh & $\begin{array}{l}\text { alluvium, } \\
\text { sedimentary }\end{array}$ & $\begin{array}{l}\text { Murray, Snow } \\
\text { Coulee }\end{array}$ & $\begin{array}{c}\text { Montana Northwestern } \\
\text { Glaciated Plains }\end{array}$ & low, mod \\
\hline D010 & Montane -Steep gradient streams & $\begin{array}{c}\text { headwater, } \\
\text { creek }\end{array}$ & moderate & & $\begin{array}{c}\text { Sandstone, } \\
\text { limestone, shales }\end{array}$ & & Rocky Mtn Front & moderate, high \\
\hline E001 & $\begin{array}{l}\text { Alpine/Montane -Steep gradient } \\
\text { streams }\end{array}$ & $\begin{array}{l}\text { headwater, } \\
\text { creek }\end{array}$ & high & M332Ah & Granite/volcanic & $\begin{array}{l}\text { E. Fork Boulder, } \\
\text { Hellroaring Creek }\end{array}$ & Beartooth Plateau & moderate, high \\
\hline E002 & $\begin{array}{l}\text { Alpine/Montane -Moderate gradient } \\
\text { streams }\end{array}$ & $\begin{array}{c}\text { headwater, } \\
\text { creek }\end{array}$ & high & $\begin{array}{l}\text { M332C, } \\
\text { M332Dh }\end{array}$ & $\begin{array}{c}\text { Sandstone, } \\
\text { limestone, shales }\end{array}$ & $\begin{array}{l}\text { Waldron Creek, } \\
\text { Urvi Creek }\end{array}$ & $\begin{array}{l}\text { Rocky Mtn Front } \\
\text { Belt Mtns }\end{array}$ & moderate, high \\
\hline E003 & Alpine/Montane -Low gradient streams & $\begin{array}{c}\text { headwater, } \\
\text { creek }\end{array}$ & high & & Alluvium & & & moderate, high \\
\hline E005 & $\begin{array}{l}\text { Small Intermittent Fishless Prairie } \\
\text { stream pools, origins in the } \\
\text { Northwestern Great plains and foothills }\end{array}$ & $\begin{array}{l}\text { headwater, } \\
\text { creek }\end{array}$ & low/mod & $331 \mathrm{Ge}$ & sedimentary & $\begin{array}{l}\text { Lame Deer, E. } \\
\text { Fork Hanging } \\
\text { Woman }\end{array}$ & Sedimentary high plains & low, mod \\
\hline E006 & $\begin{array}{l}\text { Small Intermittent Prairie streams, } \\
\text { origins in the Northern Glaciated plains } \\
\text { and foothills }\end{array}$ & $\begin{array}{c}\text { headwater, } \\
\text { creek }\end{array}$ & low/mod & 331Dh & $\begin{array}{l}\text { alluvium, } \\
\text { sedimentary }\end{array}$ & $\begin{array}{l}\text { Cowen Coulee, } \\
\text { Coburg Coulee, }\end{array}$ & $\begin{array}{c}\text { Montana Northwestern } \\
\text { Glaciated Plains }\end{array}$ & low, mod \\
\hline
\end{tabular}




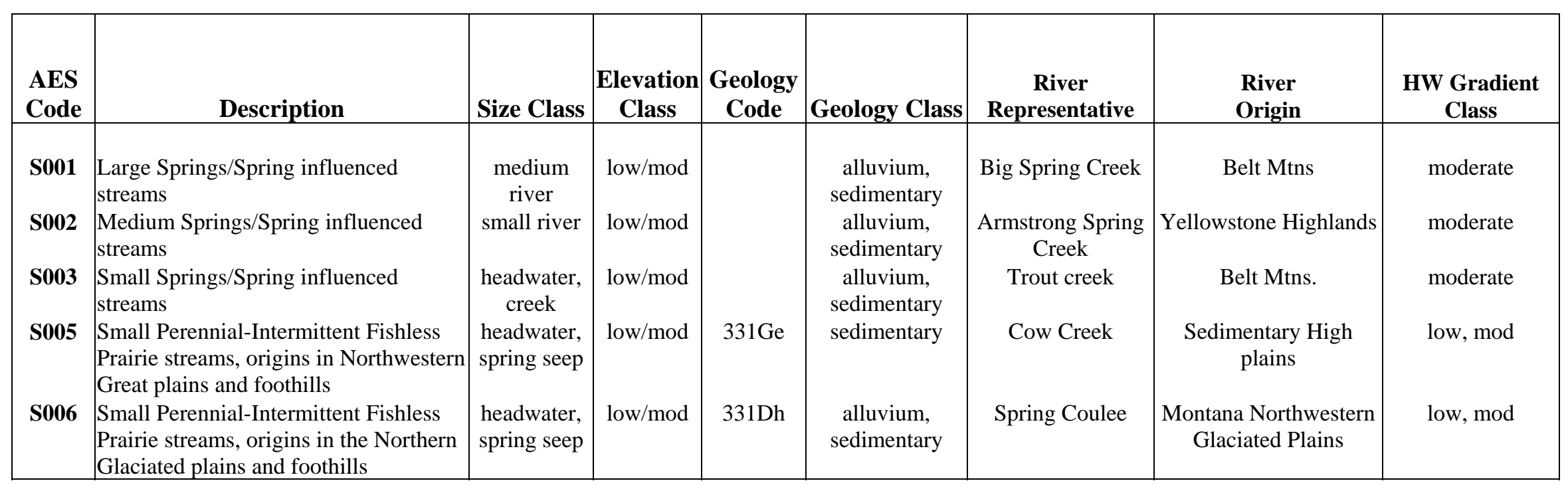

1. AES Code - Aquatic Ecological System unique identifier code. Alpha-numeric. First letter refers to stream size; $\mathrm{A}=$ large river, $\mathrm{B}=$ medium river, $\mathrm{C}=$ small river, $\mathrm{D}=$ creek/headwater, $\mathrm{E}=$ headwaters, $\mathrm{S}=$ spring creek

2. Description - General description of the Aquatic Ecological System. Specific details of Aquatic Ecological System classification attributes are in the following fields.

3. Size Class - Dominant stream/river size of the Aquatic System

4. Elevation Class - Prominent elevation class in the Aquatic System: low $=1000 \mathrm{~m}, \bmod =1000-2000 \mathrm{~m}$, high $=>2500 \mathrm{~m}$

5. Geology Code - Ecological Subsection code corresponding to the lithology and surficial geology classes in the Aquatic System's contributing area

6. Geology Class - Prominent bedrock and surficial geology classes present in the Aquatic System's contributing area

7. River Representative- examples of rivers in MT that fit the Aquatic Ecological Systems profile.

8. River Origin - For small, medium, and large river Aquatic Systems - Physiographic province(s) where the river has its origin

9. HW Gradient Class - Prominent gradient class $(\mathrm{m} / \mathrm{km})$ of headwater size streams in the Aquatic System: low $=<2 \%$, $\mathrm{mod}=2-5 \%$, high $=>5 \%$ 


\section{Appendix B. Stream Classification and Ecologically Coded Reaches for the Pilot Watersheds}





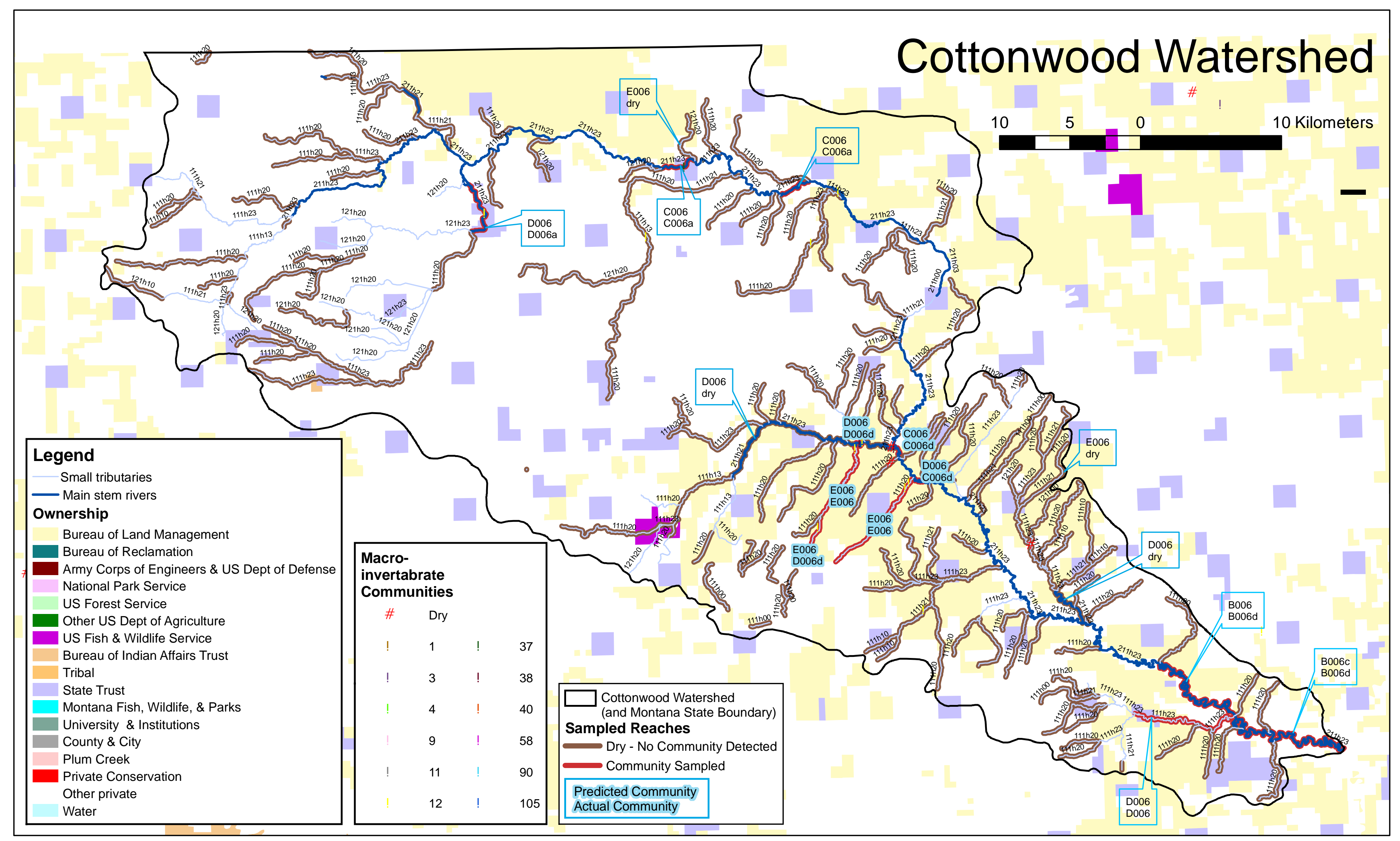




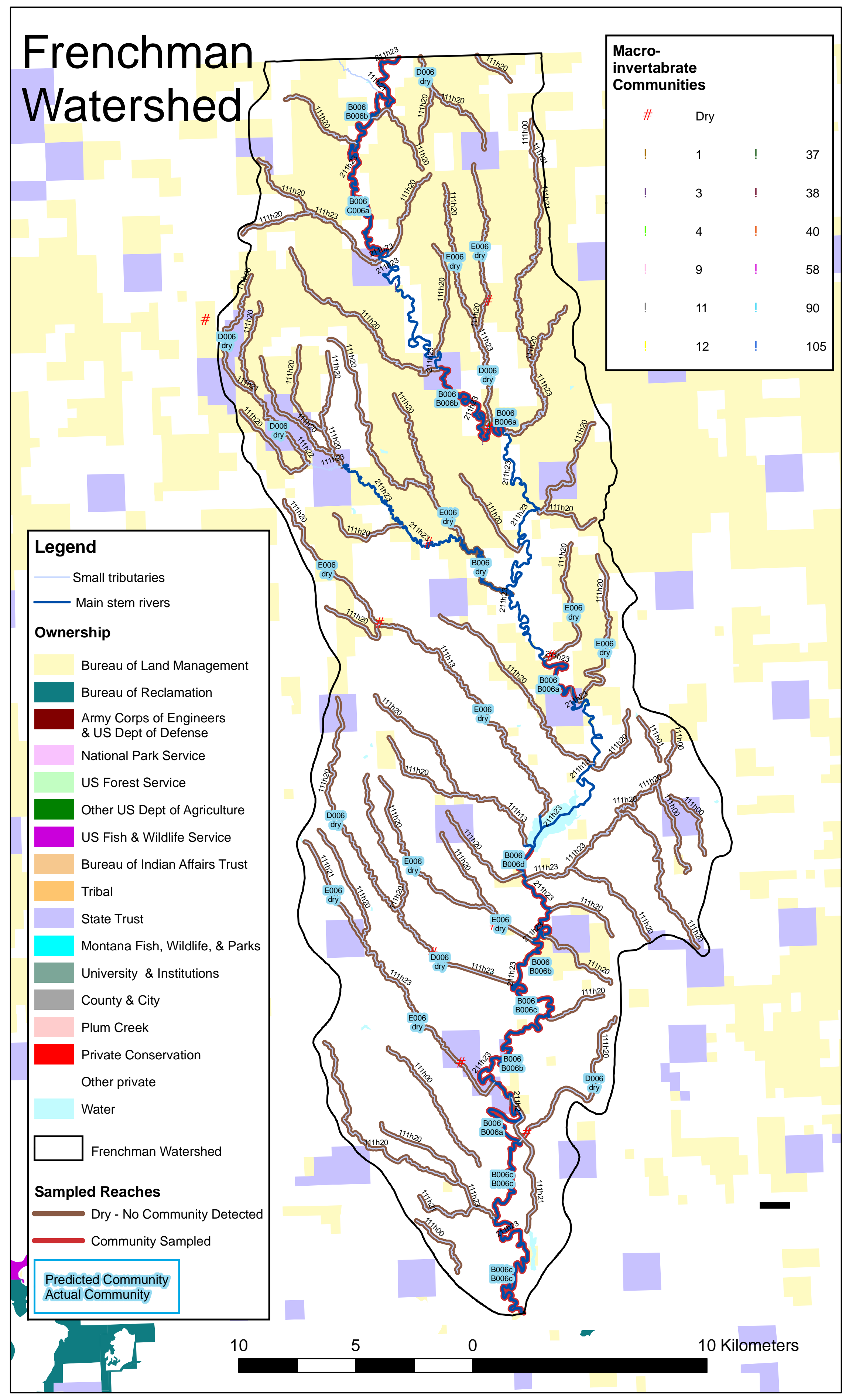




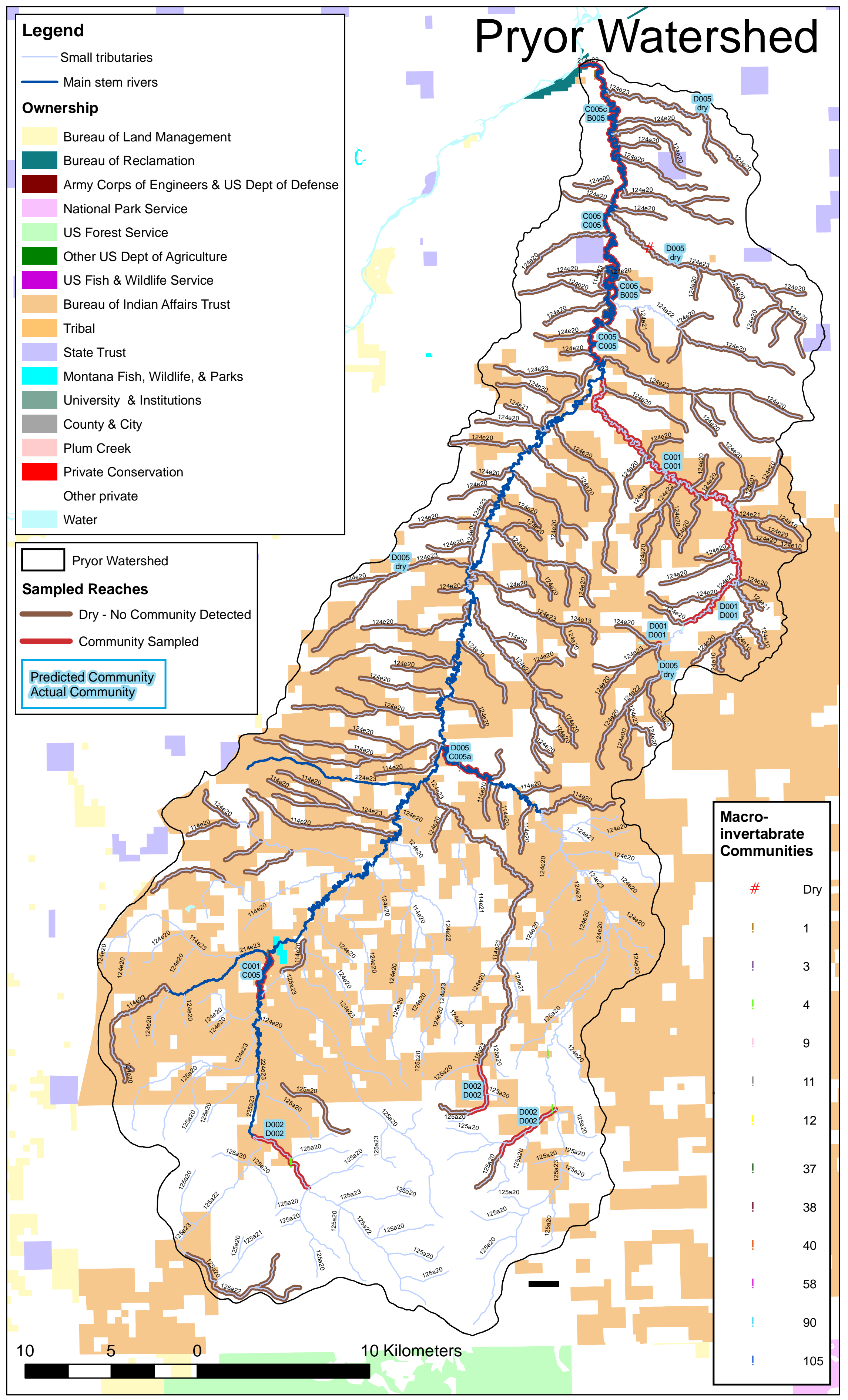




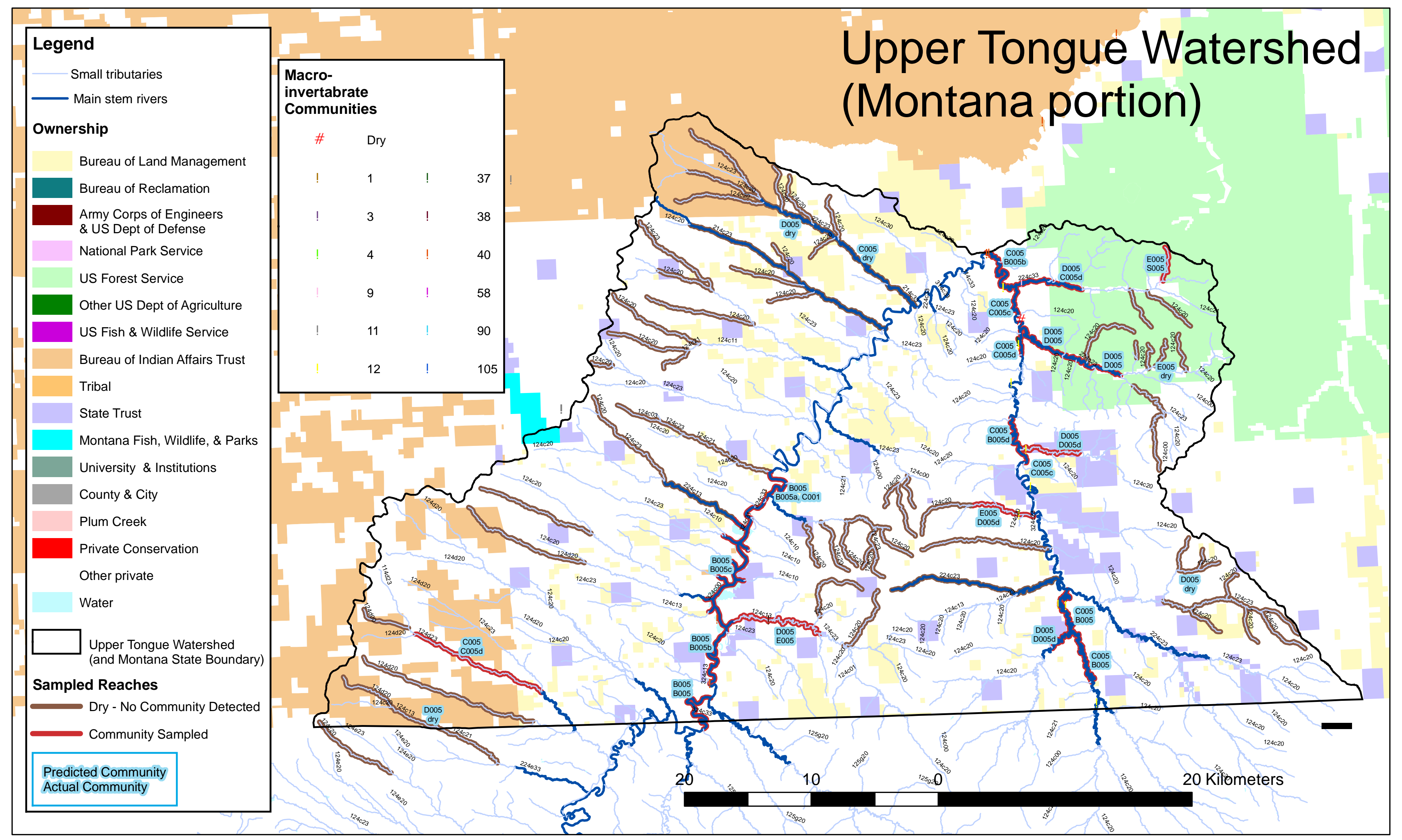




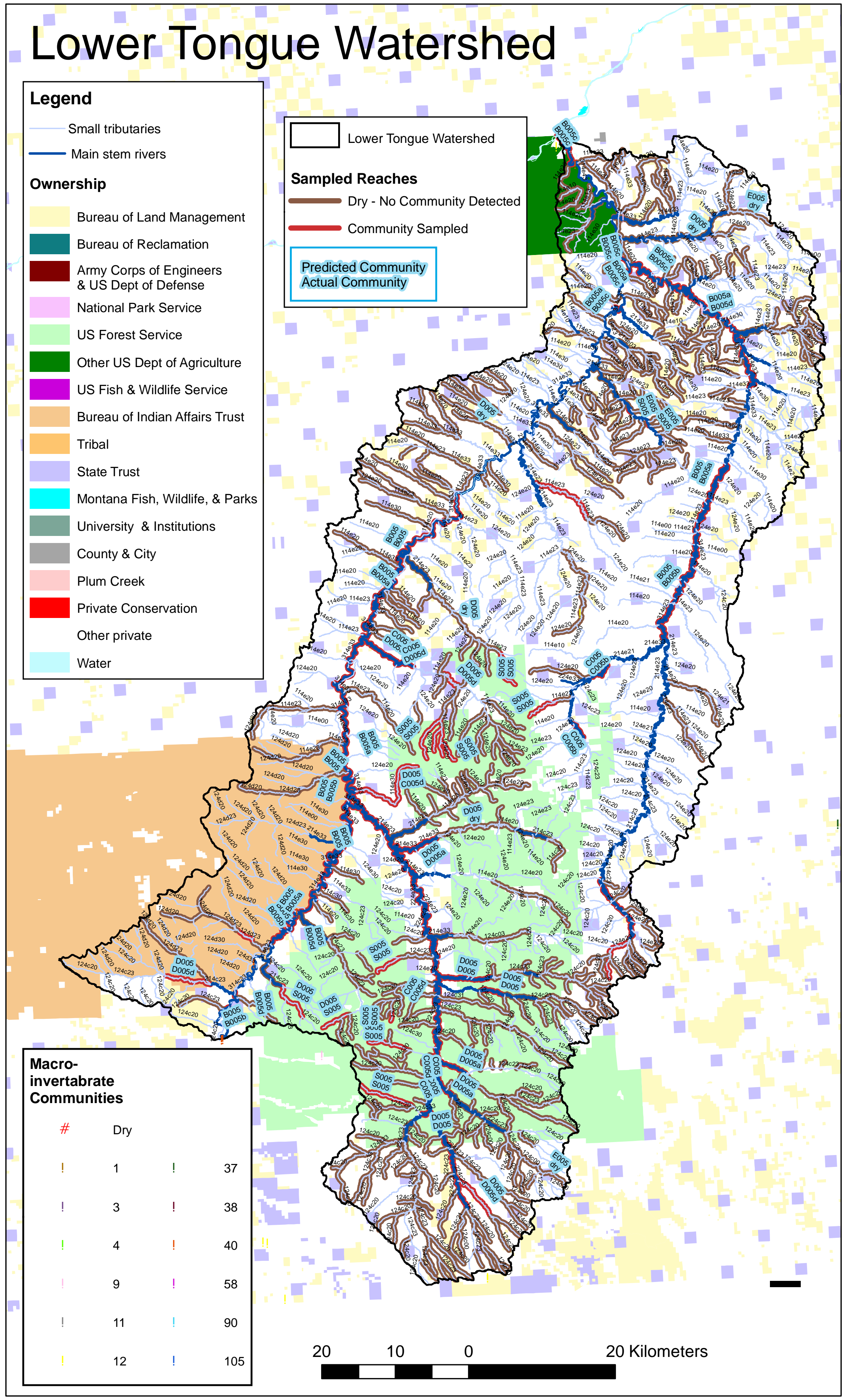




\section{APPENDIX C. MACROINVERTEBRATE COMMUNITY GROUP INDICATOR SPECIES RECORDED FROM SITES WITHIN THE DATABASE}



Appendix C. Significant indicator species $(\mathbf{p}<0.05)$ of the macroinvertebrate community groups. OIV = Observed Indicator Value of that taxon.

\begin{tabular}{|c|c|c|c|c|c|}
\hline Taxon & Group & OIV & Average & Std Dev & p-value \\
\hline Hydropsyche sp & 1 & 34.4 & 9.8 & 2.86 & 0.001 \\
\hline Optioservus sp & 1 & 52.1 & 10.4 & 3.25 & 0.001 \\
\hline Baetis tricaudatus & 1 & 46.4 & 10.3 & 2.52 & 0.001 \\
\hline Brachycentrus occidentalis & 1 & 34.1 & 8.7 & 3.59 & 0.001 \\
\hline Eukiefferiella sp & 1 & 30.2 & 8.2 & 2.93 & 0.001 \\
\hline Skwala & 1 & 22.5 & 7.6 & 3.44 & 0.005 \\
\hline Parametriocnemus & 1 & 19.4 & 7.4 & 2.86 & 0.008 \\
\hline Hydroptila sp & 1 & 17.1 & 7.5 & 2.77 & 0.012 \\
\hline Tvetenia sp. & 1 & 16.9 & 7.6 & 3.25 & 0.021 \\
\hline Zaitzevia parvula & 1 & 17.6 & 7.7 & 3.65 & 0.026 \\
\hline Oecetis sp. & 1 & 14.5 & 6.8 & 3.03 & 0.027 \\
\hline Wormaldia sp. & 1 & 12.4 & 4.8 & 2.85 & 0.031 \\
\hline Attenella margarita & 1 & 6.3 & 3.1 & 1.86 & 0.051 \\
\hline Malenka sp. & 1 & 10.8 & 5.3 & 3.17 & 0.053 \\
\hline Cricotopus sp. & 3 & 40.6 & 11.8 & 3.83 & 0.001 \\
\hline Rheotanytarsus & 3 & 31.7 & 8.8 & 3.6 & 0.002 \\
\hline Tricorythodes & 3 & 26.5 & 10 & 3.47 & 0.003 \\
\hline Cricotopus trifascia grp & 3 & 31.5 & 7.9 & 3.79 & 0.003 \\
\hline Naididae & 3 & 24.2 & 7.3 & 3.61 & 0.004 \\
\hline Oecetis avara grp & 3 & 19 & 5.5 & 3.53 & 0.009 \\
\hline Monodiamesa sp. & 3 & 14.1 & 4.8 & 3.04 & 0.015 \\
\hline Camelobatidius & 3 & 15.5 & 5.3 & 3.16 & 0.015 \\
\hline Stenelmis sp. & 3 & 21.4 & 7.8 & 4.3 & 0.016 \\
\hline Leucotrichia pictipes & 3 & 13.9 & 4.6 & 2.91 & 0.017 \\
\hline Neotrichia sp. & 3 & 13.9 & 5 & 3.19 & 0.022 \\
\hline Psychomyia sp. & 3 & 11.2 & 4.7 & 2.93 & 0.039 \\
\hline Fallceon quilleri & 3 & 13.7 & 6.8 & 3.34 & 0.041 \\
\hline Acentrella insignificans & 3 & 15 & 7.1 & 3.62 & 0.043 \\
\hline Ephoron album & 3 & 13.7 & 6.1 & 3.61 & 0.044 \\
\hline Travarella albertana & 3 & 10.1 & 5.3 & 3.08 & 0.051 \\
\hline Antocha & 4 & 32.3 & 7.1 & 2.95 & 0.001 \\
\hline Brachycentrus americanus & 4 & 56.2 & 9.2 & 3.74 & 0.001 \\
\hline Lepidostoma & 4 & 47 & 9.4 & 3.97 & 0.001 \\
\hline Ephemerella inermis & 4 & 57.6 & 7.9 & 3.4 & 0.001 \\
\hline Glossosoma sp. & 4 & 70.5 & 8.1 & 3.59 & 0.001 \\
\hline Pteronarcys californica & 4 & 24.4 & 4.5 & 3.13 & 0.001 \\
\hline Hesperoperla pacifica & 4 & 25.1 & 6.9 & 2.92 & 0.002 \\
\hline Bibiocephela sp. & 4 & 22.7 & 3.9 & 2.46 & 0.002 \\
\hline
\end{tabular}




\begin{tabular}{|c|c|c|c|c|c|}
\hline Hexatoma & 4 & 21 & 7.9 & 2.92 & 0.007 \\
\hline Chelifera sp. & 4 & 15 & 5.7 & 2.79 & 0.019 \\
\hline Atherix sp. & 4 & 17.9 & 7.2 & 3.6 & 0.02 \\
\hline Lymnaeidae & 4 & 11.9 & 5 & 2.84 & 0.029 \\
\hline Prodiamesa & 4 & 10.1 & 4.1 & 2.78 & 0.036 \\
\hline Cricotopus Nostoccocladius & 4 & 13.7 & 5.9 & 3.48 & 0.037 \\
\hline Diura & 4 & 9.1 & 4.1 & 2.45 & 0.051 \\
\hline Caenis latipennis & 9 & 66.5 & 7.7 & 3.37 & 0.001 \\
\hline Ceratopogon sp. & 9 & 37.1 & 8.5 & 3.94 & 0.001 \\
\hline Coenagrion & 9 & 52.3 & 6.3 & 3.37 & 0.001 \\
\hline Labrundinia & 9 & 26.2 & 3.9 & 2.51 & 0.001 \\
\hline Dubiraphia & 9 & 21.1 & 3.8 & 2.48 & 0.002 \\
\hline Enallagma civile & 9 & 17.6 & 3.8 & 2.35 & 0.003 \\
\hline Physella & 9 & 27.7 & 11.1 & 3.52 & 0.005 \\
\hline Enallagma sp. & 9 & 16.6 & 3.9 & 2.42 & 0.005 \\
\hline Sigara alternata & 9 & 16.4 & 4.5 & 3.16 & 0.011 \\
\hline Psectrocladius & 9 & 13.5 & 4.6 & 2.95 & 0.024 \\
\hline Sigara grosslineata & 9 & 11.8 & 4.2 & 2.89 & 0.029 \\
\hline Trichocorixa & 9 & 9.1 & 3.9 & 2.36 & 0.046 \\
\hline Cheumatopsyche & 11 & 54.7 & 9.9 & 3.18 & 0.001 \\
\hline Chironomidae & 11 & 23.3 & 5.9 & 3.37 & 0.003 \\
\hline Neochoroterpes oklahoma & 11 & 16.6 & 4.2 & 2.7 & 0.005 \\
\hline Choroterpes & 11 & 23.5 & 7.3 & 4.14 & 0.009 \\
\hline Ambrysus mormom & 11 & 19.9 & 7.1 & 3.72 & 0.011 \\
\hline Hemerodromia & 11 & 18.4 & 6.1 & 3.69 & 0.015 \\
\hline Microcylloepus & 11 & 13.6 & 5.5 & 3.08 & 0.026 \\
\hline Hydropsyche morosa grp & 11 & 12.2 & 5.8 & 3.16 & 0.044 \\
\hline Hydrochus & 11 & 8.8 & 4.1 & 2.77 & 0.048 \\
\hline Hyalella & 12 & 62.2 & 9.5 & 3.24 & 0.001 \\
\hline Coenagrion/Enallagma & 12 & 32.7 & 4.8 & 2.67 & 0.001 \\
\hline Gammarus sp. & 12 & 27.8 & 7 & 3.79 & 0.004 \\
\hline Callibaetis & 12 & 30.4 & 7.4 & 4.02 & 0.005 \\
\hline Glyptotendipes & 12 & 18.7 & 6 & 3.37 & 0.005 \\
\hline Trichocorixa nais & 12 & 15 & 3.9 & 2.58 & 0.005 \\
\hline Gyraulus & 12 & 22.4 & 7.2 & 3.79 & 0.008 \\
\hline Endochironomus & 12 & 18.5 & 5.8 & 3.7 & 0.008 \\
\hline Haliplus & 12 & 17 & 5.7 & 3.03 & 0.009 \\
\hline Paratanytarsus sp. & 12 & 20.2 & 5.6 & 3.54 & 0.011 \\
\hline Mystacides sp. & 12 & 13.2 & 4.2 & 2.76 & 0.015 \\
\hline Molanna & 12 & 10 & 4 & 2.64 & 0.033 \\
\hline Hygrotus & 12 & 9.8 & 4.1 & 2.72 & 0.044 \\
\hline
\end{tabular}




\begin{tabular}{|c|c|c|c|c|c|}
\hline Caenis youngi & 12 & 9.1 & 4.1 & 2.63 & 0.049 \\
\hline Erpobdella & 12 & 11.1 & 5.3 & 3.07 & 0.05 \\
\hline Corisella & 12 & 9.4 & 4.2 & 2.87 & 0.05 \\
\hline Stagnicola & 12 & 12 & 5.4 & 3.6 & 0.051 \\
\hline Simulium sp. & 37 & 67.6 & 13.2 & 3.78 & 0.001 \\
\hline Isonychia sp. & 37 & 21.4 & 6.6 & 3.87 & 0.01 \\
\hline Stylurus sp. & 37 & 10.7 & 4 & 2.6 & 0.02 \\
\hline Eukiefferella claripennis grp & 37 & 12.1 & 4.7 & 3.07 & 0.029 \\
\hline Pseudocloeon & 37 & 9.4 & 4.4 & 2.85 & 0.049 \\
\hline Hydropsyche confusa & 37 & 10.8 & 5 & 3.32 & 0.05 \\
\hline Tanytarsus sp. & 38 & 49.5 & 10.8 & 4.68 & 0.001 \\
\hline Dicrotendipes & 38 & 24.5 & 8.1 & 3.34 & 0.002 \\
\hline Cladotanytarsus & 38 & 32.5 & 10.1 & 5.04 & 0.005 \\
\hline Ablabesmyia sp. & 38 & 17.4 & 6.1 & 2.74 & 0.006 \\
\hline Polycentropus & 38 & 16.4 & 5.4 & 3.23 & 0.011 \\
\hline Chironomus sp. & 38 & 19.3 & 7.3 & 3.75 & 0.016 \\
\hline Paratanytarsus & 38 & 16.1 & 7.2 & 3.23 & 0.02 \\
\hline Sigara sp. & 38 & 17.8 & 6.8 & 3.98 & 0.021 \\
\hline Culicoides sp. & 38 & 12.3 & 5 & 3.35 & 0.037 \\
\hline Pseudocloeon sp. & 38 & 14.9 & 7.5 & 3.78 & 0.049 \\
\hline Gomphidae & 38 & 9.7 & 4.5 & 2.94 & 0.051 \\
\hline Ithythrichia & 38 & 10.6 & 5 & 3.15 & 0.052 \\
\hline Corixidae & 40 & 71.1 & 8.4 & 3.26 & 0.001 \\
\hline Cryptotendipes & 40 & 21.7 & 6.2 & 3.45 & 0.004 \\
\hline Placobdella & 40 & 14.3 & 4.3 & 2.61 & 0.004 \\
\hline Tubifex & 40 & 16.4 & 4.3 & 2.68 & 0.007 \\
\hline Procladius & 40 & 20.4 & 6.9 & 3.31 & 0.008 \\
\hline Cryptochironomus & 40 & 15.7 & 6.7 & 2.46 & 0.009 \\
\hline Stempelinella & 40 & 18.8 & 5.5 & 3.36 & 0.013 \\
\hline Tanypus & 40 & 14.5 & 6.2 & 3.54 & 0.041 \\
\hline Centroptilum & 40 & 11 & 4.8 & 2.84 & 0.047 \\
\hline Gompus sp. & 40 & 9.4 & 4.2 & 2.85 & 0.052 \\
\hline Palmacorixa gilletti & 40 & 11.6 & 5.4 & 3.44 & 0.053 \\
\hline Probezzia & 40 & 11.1 & 5.5 & 3.61 & 0.053 \\
\hline Enchytriidae & 58 & 27.6 & 5.6 & 2.72 & 0.001 \\
\hline Rhithrogena & 58 & 42.8 & 8.7 & 3.2 & 0.001 \\
\hline Drunella doddsi & 58 & 34.8 & 7.2 & 2.96 & 0.001 \\
\hline Cinygmula & 58 & 59.9 & 7.2 & 3.32 & 0.001 \\
\hline Epeorus longimanus & 58 & 47.2 & 7.1 & 3.68 & 0.001 \\
\hline Rhyacophila betteni & 58 & 29.4 & 5.2 & 2.74 & 0.001 \\
\hline
\end{tabular}




\begin{tabular}{|c|c|c|c|c|c|}
\hline Drunella coloradensis & 58 & 26.5 & 6.2 & 2.83 & 0.001 \\
\hline Megarcys & 58 & 75.6 & 6.1 & 2.94 & 0.001 \\
\hline Zapada oregonensis & 58 & 51.3 & 5.8 & 3.29 & 0.001 \\
\hline Baetis bicaudatus & 58 & 38.1 & 6.4 & 3.47 & 0.001 \\
\hline Epeorus grandis & 58 & 76.7 & 6.5 & 3.57 & 0.001 \\
\hline Parapsyche elsis & 58 & 37.9 & 4.9 & 2.99 & 0.001 \\
\hline Zapada columbiana & 58 & 32.9 & 5.6 & 3.09 & 0.001 \\
\hline Rhyaphila siberica grp & 58 & 21.5 & 4.3 & 2.76 & 0.001 \\
\hline Rhyacophila hylineata grp & 58 & 34.8 & 6.3 & 3.28 & 0.002 \\
\hline Epeorus albertae & 58 & 26 & 5.5 & 3.4 & 0.002 \\
\hline Epeorus deceptivus & 58 & 26.6 & 5.5 & 3.46 & 0.003 \\
\hline Zapada cinctipes & 58 & 24.2 & 7.4 & 3.47 & 0.004 \\
\hline Ameletus & 58 & 25.9 & 7.3 & 3.5 & 0.004 \\
\hline Rhyacophila verrula & 58 & 13.3 & 3.9 & 2.5 & 0.011 \\
\hline Rhyacophila iranda grp & 58 & 12.8 & 4 & 2.77 & 0.013 \\
\hline Doroneuria & 58 & 23.5 & 8.6 & 4.72 & 0.019 \\
\hline Rhabdomastix & 58 & 12.5 & 4.1 & 2.68 & 0.026 \\
\hline Apatania & 58 & 12.5 & 5.5 & 3.25 & 0.04 \\
\hline Rhyacophila albertae & 58 & 11.5 & 5 & 3.08 & 0.049 \\
\hline Tvetenia bavarica grp & 90 & 46.6 & 6.2 & 2.99 & 0.001 \\
\hline Orthocladius sp. & 90 & 37 & 10.6 & 3.22 & 0.001 \\
\hline Heterlimnius & 90 & 46.7 & 7.3 & 3.07 & 0.001 \\
\hline Sweltsa & 90 & 43.7 & 7.3 & 3.07 & 0.001 \\
\hline Psychoglypha & 90 & 22.6 & 5.3 & 3.02 & 0.001 \\
\hline Eukiefferella gracei grp & 90 & 29.6 & 6.3 & 3.3 & 0.001 \\
\hline Rhyacophila brunnea grp & 90 & 25.3 & 7.2 & 2.72 & 0.002 \\
\hline Glutops & 90 & 24.5 & 4.8 & 2.97 & 0.002 \\
\hline Micropsectra sp. & 90 & 25.8 & 9.3 & 3.25 & 0.003 \\
\hline Polycelis cornuta & 90 & 23.8 & 5.2 & 3.23 & 0.003 \\
\hline Pisidiium & 90 & 20.8 & 7.5 & 3.11 & 0.004 \\
\hline Serretella tibialis & 90 & 24.9 & 5.8 & 3.11 & 0.004 \\
\hline Rhyacophila narvae & 90 & 22 & 4.8 & 3.16 & 0.004 \\
\hline Micrasema sp. & 90 & 29 & 8.7 & 4.54 & 0.005 \\
\hline Pseudodiamesa & 90 & 15.7 & 4.1 & 2.49 & 0.006 \\
\hline Pagastia sp. & 90 & 23.4 & 9.7 & 3.65 & 0.007 \\
\hline Yoraperla & 90 & 16.9 & 4.7 & 2.81 & 0.007 \\
\hline Ostracoda & 90 & 20.2 & 6.7 & 3.37 & 0.008 \\
\hline Drunella grandis & 90 & 17 & 6.4 & 3.1 & 0.01 \\
\hline Perlodidae & 90 & 13.2 & 4.6 & 2.64 & 0.015 \\
\hline Brillia & 90 & 22.2 & 8.6 & 4.58 & 0.017 \\
\hline Visokia cataractae & 90 & 12.7 & 4.5 & 2.65 & 0.019 \\
\hline Turbellaria & 90 & 17.8 & 7.7 & 3.22 & 0.02 \\
\hline Caudatella hystrix & 90 & 18.9 & 6.2 & 3.89 & 0.023 \\
\hline
\end{tabular}




\begin{tabular}{|c|c|c|c|c|c|}
\hline Leuctridae & 90 & 11.1 & 3.9 & 2.6 & 0.028 \\
\hline Neothremma & 90 & 14.3 & 5 & 3.27 & 0.028 \\
\hline Cleptelmis & 90 & 13.9 & 5.4 & 3.21 & 0.029 \\
\hline Clinocera sp. & 90 & 11.5 & 4.5 & 2.53 & 0.029 \\
\hline Limnophora & 90 & 12.5 & 5 & 3.48 & 0.037 \\
\hline Eukiefferella devonica & 90 & 14.4 & 6.5 & 3.49 & 0.042 \\
\hline Caudatella sp. & 90 & 8.8 & 3.9 & 2.46 & 0.046 \\
\hline Neophylax rickeri & 90 & 9.8 & 4.6 & 3.29 & 0.051 \\
\hline Helicopsyche borealis & 105 & 51.5 & 8.2 & 3.93 & 0.001 \\
\hline Corynoneura sp. & 105 & 41.4 & 8.2 & 4.16 & 0.001 \\
\hline Constempellina sp. & 105 & 60.2 & 5.2 & 2.78 & 0.001 \\
\hline Nanocladius sp. & 105 & 79.9 & 7.5 & 4.3 & 0.001 \\
\hline Prosimulium & 105 & 64.5 & 5.4 & 3.15 & 0.001 \\
\hline Amiocentrus aspilis & 105 & 32.5 & 8.2 & 4.58 & 0.001 \\
\hline Lara & 105 & 32.5 & 4.4 & 2.75 & 0.001 \\
\hline Phaenopsectra & 105 & 32.7 & 6.4 & 3.6 & 0.001 \\
\hline Plauditus punctiventris & 105 & 78.9 & 5.5 & 2.85 & 0.001 \\
\hline Narpus concolor & 105 & 92.2 & 5 & 2.94 & 0.001 \\
\hline Hexagenia limbata & 105 & 30 & 5.3 & 2.92 & 0.001 \\
\hline Erioptera & 105 & 38.5 & 4.3 & 2.61 & 0.001 \\
\hline Diamesa sp. & 105 & 52 & 6.7 & 3.19 & 0.001 \\
\hline Ptychoptera & 105 & 22.9 & 4.8 & 3.2 & 0.001 \\
\hline Protanydarus & 105 & 36 & 4.8 & 3.24 & 0.001 \\
\hline Diplocladius sp. & 105 & 97.3 & 4.9 & 3.13 & 0.001 \\
\hline Setvena & 105 & 61.5 & 5.1 & 3.25 & 0.001 \\
\hline Paraperla & 105 & 32 & 3.9 & 2.55 & 0.001 \\
\hline Agraylia & 105 & 46.5 & 4.6 & 3.2 & 0.001 \\
\hline Blepharicera & 105 & 21.8 & 3.7 & 2.24 & 0.001 \\
\hline Ephemerella infrequens & 105 & 37.3 & 4.9 & 3.21 & 0.001 \\
\hline Acentrella edmundsi & 105 & 36.5 & 4 & 2.68 & 0.001 \\
\hline Nemotaulius & 105 & 35.5 & 3.9 & 2.55 & 0.001 \\
\hline Tipulidae & 105 & 16.4 & 4 & 2.55 & 0.002 \\
\hline Ordobrevia nubifera & 105 & 27.4 & 5.2 & 2.96 & 0.002 \\
\hline Acricotopus & 105 & 21.2 & 4.1 & 2.79 & 0.002 \\
\hline Leucrocuta & 105 & 24 & 6.2 & 3.52 & 0.004 \\
\hline Helichus & 105 & 18 & 4 & 2.61 & 0.004 \\
\hline Culoptila & 105 & 20.4 & 5.7 & 3.39 & 0.005 \\
\hline Rhyacophila sp. & 105 & 21.4 & 4.3 & 2.96 & 0.005 \\
\hline Parakiefferiella & 105 & 18.7 & 6.3 & 3.3 & 0.007 \\
\hline Pteronocella badia & 105 & 18.2 & 5.2 & 3.04 & 0.009 \\
\hline Epeorus & 105 & 17.2 & 5.3 & 3.36 & 0.01 \\
\hline Hydroptila sp. & 105 & 14.4 & 4 & 2.7 & 0.011 \\
\hline Nilothauma & 105 & 13.8 & 3.9 & 2.59 & 0.012 \\
\hline
\end{tabular}




\begin{tabular}{lccccc}
\hline Paraleptophlebia & 105 & 12.5 & 4 & 2.31 & 0.021 \\
Amnicola & 105 & 11.7 & 4 & 2.74 & 0.023 \\
Cascadoperla & 105 & 12.5 & 4 & 2.37 & 0.025 \\
Nectopsyche & 105 & 12.6 & 5.1 & 2.65 & 0.026 \\
Pseudosmittia & 105 & 9.6 & 4 & 2.46 & 0.034 \\
Chimarra & 105 & 12.5 & 4.1 & 2.5 & 0.035 \\
Glossoma & 105 & 12.5 & 4.1 & 2.5 & 0.035 \\
Procloeon & 105 & 10.1 & 4.8 & 2.82 & 0.051 \\
\hline
\end{tabular}




\section{APPENDIX D. UnMOdifIEd OUTPUT CLASSIFICATION CLUSTER DEN- DROGRAM OF THE MACROINVERTEBRATE GROUPS}





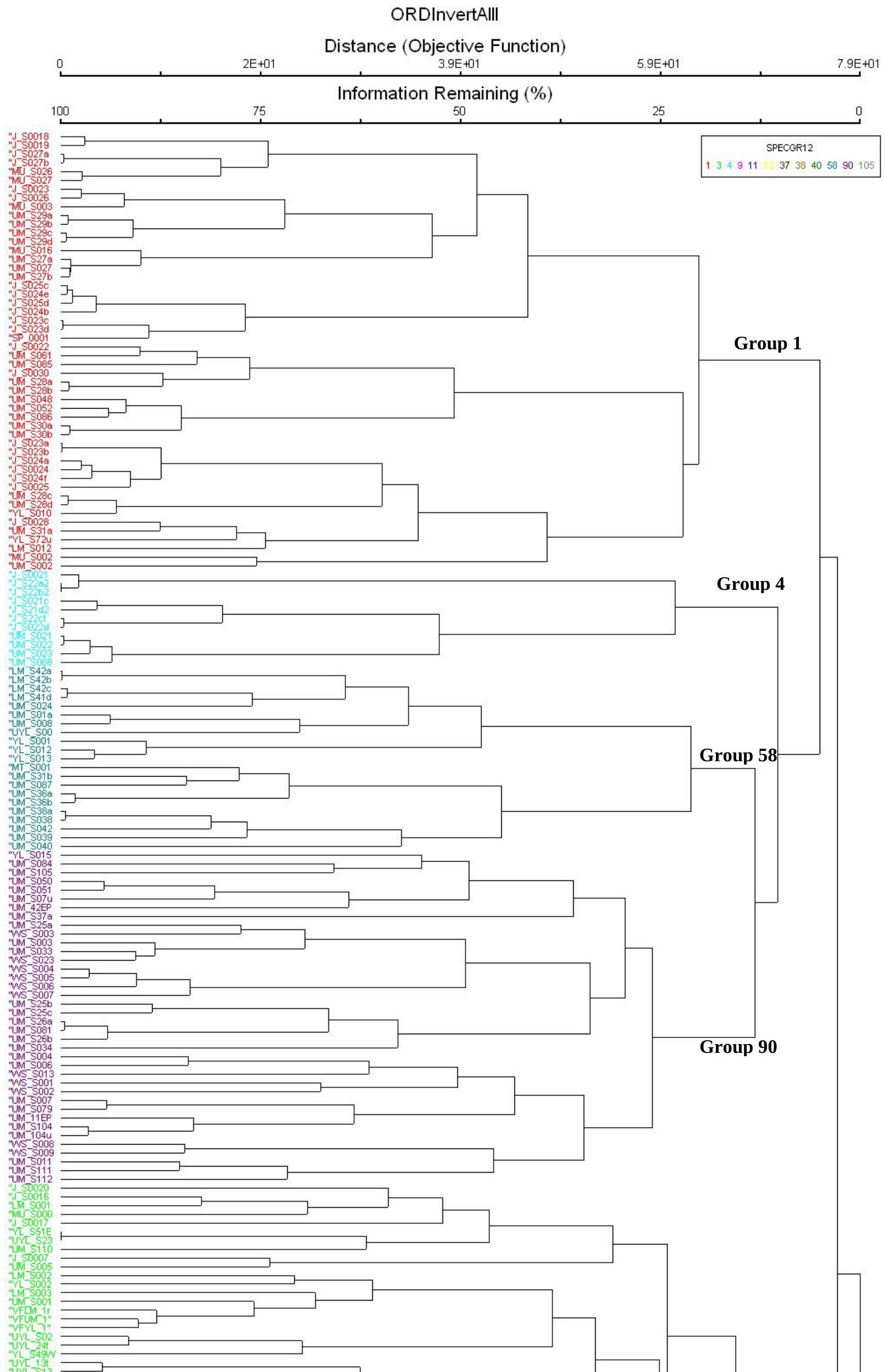




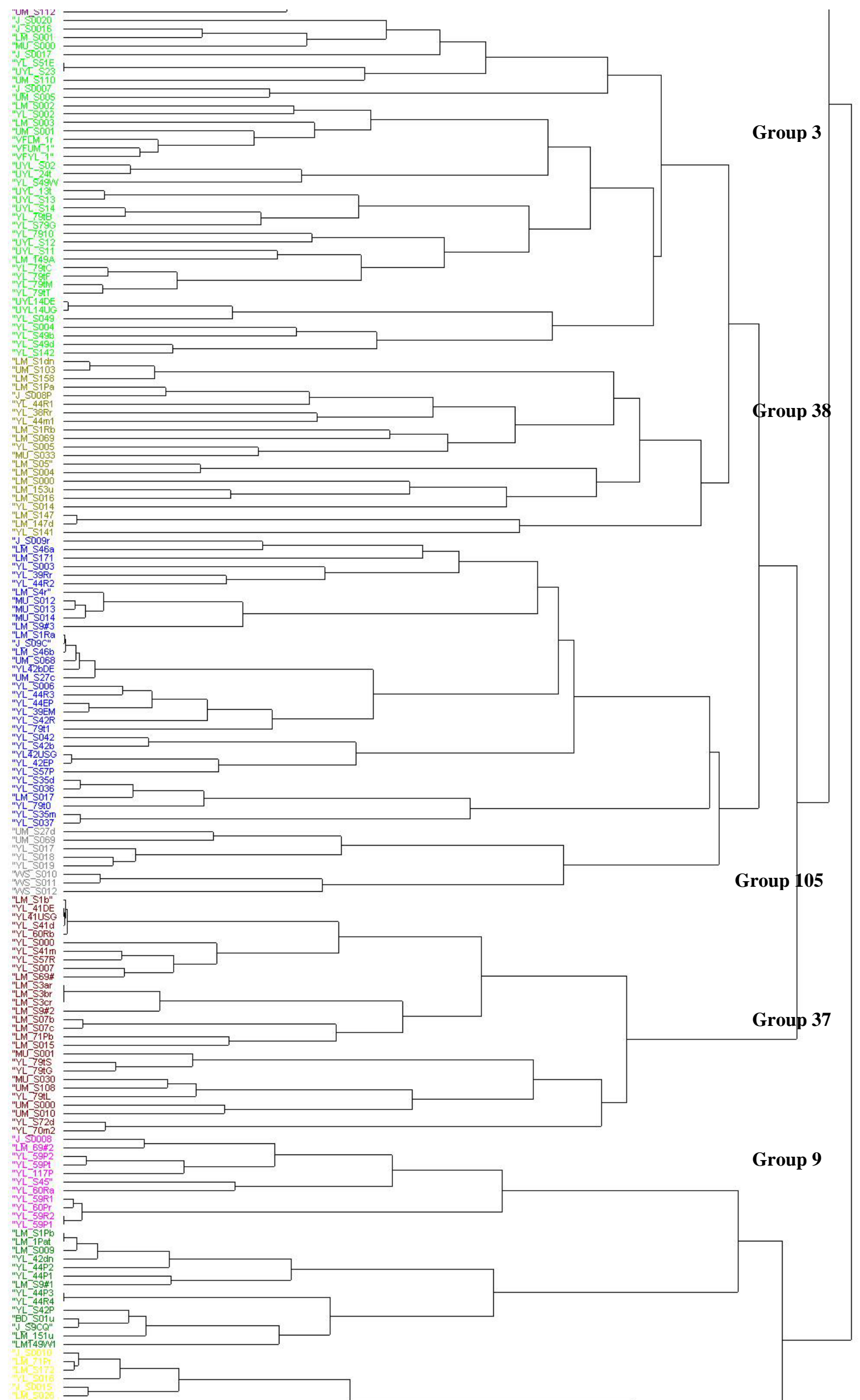




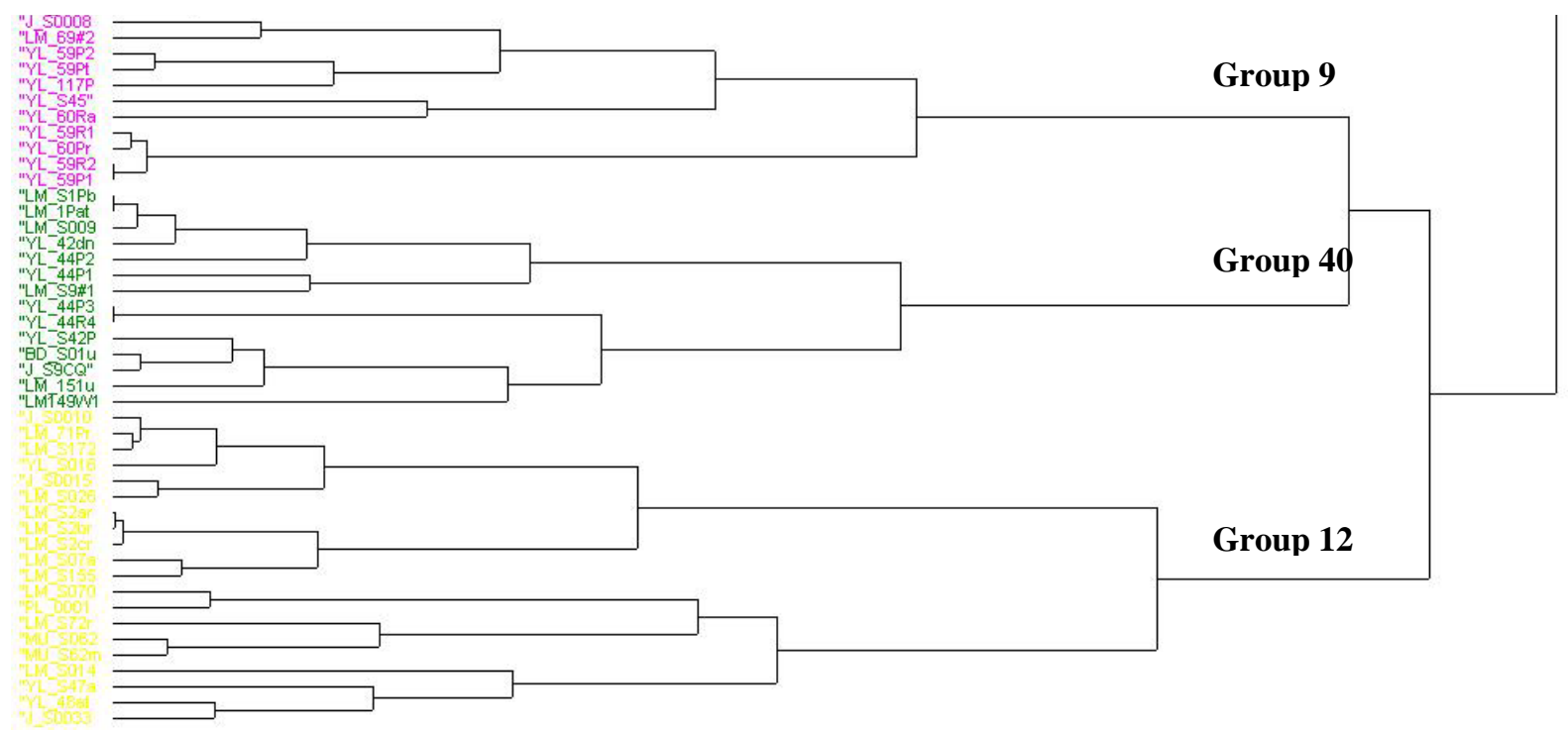





\section{Appendix E. Macroinvertebrate Community Group DESCRIPTIONS}





\section{Description of Macroinvertebrate Communities}

\section{Small- to medium-size stream communities $\left(1^{\text {st }}\right.$ to $3^{\text {rd }}$ order $)$}

Group 58 - Pristine Mountain Stream Community. Within the study area, this community only occurs in small-medium $\left(1^{\text {st }}-3^{\text {rd }}\right.$ order $)$ cold-water, confined-channel streams with undisturbed forest, high elevation and gradient, high quality habitat, and boulder/cobbledominated substrate in the aquatic ecological systems D002, D003 and D004. This group was not found within the pilot watersheds, but in the mountainous Middle Rockies Ecoregion. The indicator taxa consist of many species of Ephemeroptera, Plecoptera and Trichoptera (EPT) that are largely cold-water stenotherms, and intolerant of sediment and nutrients (Table 4). This community is found in close association with high quality, step-pool Westslope or Yellowstone Cutthroat trout habitat, usually found within our national forest lands or protected wilderness areas.

Examples in the Missouri drainage: N.F Teton, Little Boulder, Cataract, Jack, Basin Creeks; Yellowstone drainage: Hellroaring, W. Fork Stillwater, W. F. Rock Creek, Boulder River. Representative indicator taxa include: Drunella doddsi, Cinygmula, many Epeorus and Rhyacophila spp., Drunella coloradensis, Megarcys, Zapada spp., Baetis bicaudatus, Parapsyche elsis.

Group 90 - Medium Mountain Stream Community-This community type was not found in our pilot watersheds, but was present in the dataset from small-medium $\left(2^{\text {nd }}\right.$ and $4^{\text {th }}$ order), cold-water streams in the forested montane regions of ecoregions 16 and 17. These communities occur in moderate gradient, open forested streams in higher elevations with high quality habitat in Granitic, Sedimentary or Isolated Mountain Ranges. Substrates are cobble/pebble dominated with woody debris in the pool areas. This community often occurs with or downstream from the Pristine Mountain Stream Assemblage and upstream from the foothills or intermontane rivers as long as water quality and quantity are maintained. If water quality is impaired, this assemblage will degrade quickly to the Traditional Trout Stream Assemblage (a more tolerant assemblage).

Examples in the Missouri drainage: Tenderfoot, Muskrat, Boulder, Deep Creek, Jack, Basin Creeks; Yellowstone drainage: Hellroaring, W. Fork Stillwater, W. F. Rock Creek, Boulder River. Indicator taxa consist of intolerant EPT taxa: Drunella, Sweltsa, Psychoglypha, Rhyacophila brunnea grp, Serretella tibialis, Rhyacophila narvae, Micrasema.

Group S005 \& S006--Small Perennial Fishless Prairie Spring Communities. Headwater spring seeps with low/moderate gradient flowing through sedimentary lithology with origins in Northwestern Great Plains and foothills (Reference example: Cow Creek, Custer National Forest) or flowing through alluvium and sedimentary underlying lithology with origins in the Northern Montana Northwestern Glaciated plains. Indicator macroinvertebrates include the midges - Odontomesa, Radotanypus, Heleniella, Pseudodiamesa, diptera - Tipula, Dicranota, Ormosia, Pedicia, the snails - Hydrobiidae, Physa, Fossaria; the Mayfly- Baetis tricaudatus, the caddisfly-Hesperophylax designatus, the water mite and leeches-Hydrachna and Glossophona 
complanata, Placobdella, the dytiscid Beetles-Oreodytes, Hydroporus and Hygrotus, and the dramselfly larvae- Argia and Ishnura.

Group E005 \& E006--Small Intermittent Fishless Prairie Pool Communities. This community type was found in our two of our pilot watersheds. It is common in headwater and creek pools formed within low/moderate gradient streams flowing through the sedimentary lithology of the Northwestern Great Plains and foothills (Reference example: Little Bear Creek, Custer National Forest) or through alluvium and sedimentary of the Northern Glaciated plains (ex. Cowen Coulee). Indicator macroinvertebrates vary in relation to the wetted duration period of the pools, but may include: the midges-Chironomus, Cladotanytarsus, Dicrotendipes, mosquito larvae-Aedes, Culex, the snails-Helisoma, Physella, Planorbella, the water mite and leech-Hydrachna and Glossophona complanata, the dyticsid Beetles-Hydroporus, Hygrotus, Laccophilus, damselflies-Coenagrion, Lestes and the dragonfly larva - Sympetrum. If the pools are dry for more than a year and than rehydrate, many invertebrates with resting egg stages dominate the pools, including the crustaceans: Ostracoda, Cladocera, Copepoda, the fairy shrimp- Branchinecta, Eubranchipus, the clam shrimp-Caenestheriella, and the tadpole shrimpLepidurus.

\section{Medium to large streams (3rd order and larger)}

Group 1 - Medium Cool-Water Transitional Assemblage- This is a widespread community type in the study area, but only occurs in one of the pilot watersheds, and is associated with the B class of streams, medium to large $\left(3^{\text {rd }}-5^{\text {th }}\right.$ order $)$ cool-water intermountain valleys and foothills, with high linkage order, moderate forest cover, moderate gradient and elevation. It occurred in rivers that are typically trout-whitefish habitats, but also downstream in streams/rivers that are warmer than the optimal water temperature for trout, so-called "marginal waters". The habitat quality of these systems was rated medium and, since the landscape setting is foothills and valleys, they are wider, open-canopied streams with grazing and agriculture as predominant land uses. Over 50\% of the sites in this community type were classified as impaired by sediments or de-watering by the MT DEQ. Genera associated with this group are moderately tolerant to sediment and nutrients. Representative rivers include: Smith River, Big Spring, Big Otter, Musselshell, Gallatin River below $4500 \mathrm{ft}$. Representative indicator taxa are moderately tolerant and include: Hydropsyche, Optioservus, Baetis tricaudatus, Brachycentrus occidentalis

Group 3 - Transitional Prairie River Assemblage-This widespread community type occurred in more than half of the pilot watersheds and was associated with the second largest class of streams assessed in this dataset $\left(4^{\text {th }}-7^{\text {th }}\right.$ order medium to large cool-warmwater streams). Streams containing this community ( $20 \%$ A, $75 \%$ B, $5 \%$ C class) were primarily low forest cover, high order, high link, low to moderate gradient, low-moderate elevation in cool/warmwater intermountain valleys. The habitat quality of these systems was rated medium with grazing and agriculture dominant land uses in these systems, so sediment may be a problem. Genera associated with this group are moderately tolerant to sediment and nutrients. River examples: Musselshell, Tongue, Little Missouri, and transitional Missouri and Yellowstone Rivers. Representative indicator taxa: Camelobatidius, Stenelmis, Leucotrichia pictipes, 
Neotrichia, Psychomyia, Fallceon quilleri, Acentrella insignificans, Ephoron album, Travarella albertana

Group 4 - Traditional Trout Stream Assemblage- This relatively widespread community type occurs primarily in the large cold-cool water streams and medium rivers $\left(3^{\text {rd }}\right.$ to $5^{\text {th }}$ order) of the upper Missouri and Yellowstone drainages with forested land cover, moderate elevation, low development, high quality habitat, moderate gradient, and a stream substrate with large cobbles and boulders (Big Hole, Jefferson, Madison, Gallatin (above 4000ft), W.F. Gallatin River). This type may also occur in higher elevation, smaller stream sites $\left(2^{\text {nd }}-3^{\text {rd }}\right.$ order $)$ in the eastern part of the state, such as Pryor Creek or Butcher Creek. This diverse, moderately intolerant macroinvertebrate community has indicator taxa: Pteronarcys californica, Hesperoperla pacifica, Brachycentrus americanus, Lepidostoma spp. and Antocha.

Group 9 - Prairie Stream Assemblage This ubiquitous warm-water stream community type is found in all pilot watersheds and is associated with small to medium (2nd-5th order) prairie streams with the lowest elevation and gradient, low forest cover, high linkage, low gradient, lowmoderate elevation, with common low current pool areas. Although this group is found in small to large stream systems, it typically occurs in slow current areas with silted, sand /gravel /cobble substrates, often with aquatic vegetation. The riffle areas of these may have clean mixed cobble substrates similar to Group 3 habitats, but with less flow. Prairie streams examples: Larb, Pumpkin, Battle, Hanging Woman, Prairie Creek. Indicator taxa are typical of low-gradient streams and are tolerant to disturbance: Caenis latipennis, Ceratopogon, Coenagrion, Enallagma civile, Physella, Dubiraphia

Group 11 - Large Prairie River Assemblage-This group occurred in downstream confluence areas and is associated with warm-water medium and large rivers $\left(4^{\text {th }}-7^{\text {th }}\right.$ order $)$ of lower elevation and moderate gradient. Although this group is a large stream system community similar to Group 1, it is found in areas with more agricultural land use and sediment deposition than Group 1. Indicator taxa are relatively tolerant to disturbance and typical of low gradient streams with stable substrates and a slow-moderate current velocity. Example rivers: Frenchman Creek, Missouri River, and Powder Rivers. Indicator taxa consist of genera from many insect orders tolerant of sedimentation and moderate pollution: Cheumatopsyche, Neochoroterpes oklahoma, Choroterpes, Ambrysus mormom, Hemerodromia, Microcylloepus, Hydropsyche morosa grp.

Group SDM- Large River, Sand-Dwelling Mayfly Assemblage- This rare community type was not reported in the classification due to its absence in the samples. It is rarely collected in traditional bioassessment samples due to their fast swimming abilities (i.e. net avoidance) and occurrence on extensive sandbars where typical samples are not taken. This community is associated with the largest class of rivers in the classification $\left(5^{\text {th }}-7^{\text {th }}\right.$ order) that are low elevation, low to moderate gradient with shifting sandbars and islands with side channels. River representatives: Powder River and the lower Missouri and Yellowstone Rivers where suitable habitat exists. This large-river group has highly-specialized and globally rare indicator species: Analetris eximia, Raptoheptegenia cruentata, Lachlania saskatchewanensis, Anepeorus rusticus, 
Ametropus neavei and Homoeoneuria alleni, and is closely associated with species from the Large Prairie River Assemblage that occur in the riffle or other stable substrate areas.

Group 12 - Prairie Pool Assemblege-This group is associated with slow-moving small to medium warm-water prairie streams $\left(2^{\text {nd }}-5^{\text {th }}\right.$ order $)$ of low-mid elevation, low gradient, typically with heavy aquatic vegetation and low current or stagnant pool areas. Group 12 is a highly tolerant group of invertebrates that can withstand low oxygen, high temperatures and siltation. Even though this group can be found in large warmwater prairie systems, similar to Groups 9 and 11, it is found in areas with less current and higher sediment influences. Stream examples: Hanging Woman, Sarpy, Coffee, O’Fallon Creek, Thompson, Otter Creeks. Indicator taxa: Hyalella, Coenagrion/Enallagma, Gammarus sp., Callibaetis, Glyptotendipes, Trichocorixa nais, Gyraulus, Erpobdella, Corisella, Stagnicola

Group 37 - Filtering-Collector Assemblage-This moderately tolerant macroinvertebrate group is associated with warm-water medium and large rivers $\left(4^{\text {th }}-7^{\text {th }}\right.$ order) of low elevation (2000$3500 \mathrm{ft}$ ), low forest cover, high-linkages, high nutrient/turbidity and moderate gradient (slowmoderate current velocity) with stable $\rightarrow$ shifting substrates. This community occurs in silt/sand/gravel substrates of large rivers (A001, A003, B006) or smaller (C007) degraded streams with sediment and nutrient problems. Two indicator taxa, Simulium and Hydropsyche confusa, can quickly colonize newly exposed substrates, so shifting sediments will not greatly disturb this community. Most of the indicator taxa are filterer-collectors or predators and can tolerate streams with higher agricultural and sediment influences than most other large stream/ river communities.

Stream and river examples: Frenchman Creek, Battle Creek, West Fork Poplar, Little Missouri, Powder River. Indicator taxa: Simulium, Isonychia, Stylurus, Eukiefferella claripennis grp., Pseudocloeon, Hydropsyche confusa

Group 38- Large River Slow Current Assemblege- This community group is associated with medium to large $\left(3^{\text {rd }}-7^{\text {th }}\right.$ order) warmwater rivers with low forest cover, high-linkages and high nutrient/turbidity, low to moderate gradients, low elevation and substrates dominated by silt/sand/gravel or smaller degraded streams with sediment and nutrient problems. Examples: Rock Creek, Redwater, Milk and Missouri Rivers. Indicator taxa: Tanytarsus, Dicrotendipes, Cladotanytarsus, Polycentropus, Chironomus, Paratanytarsus, Sigara, Culicoides, Gomphidae, Ithythrichia

Group 40- Medium River Side-Channel Community-This community group consisting of moderately tolerant macroinvertebrates is associated with medium to large ( $3^{\text {rd }}-7^{\text {th }}$ order) coolwarmwater rivers, low forest cover, high-linkages, medium turbidity, moderate gradients, low elevation (2500-4000 ft.) gravel/cobble dominated with silted side channels. River examples: Clark’s Fork Yellowstone, Tongue, lower-Bighorn, mid-Yellowstone. Smaller degraded C001, C002, C005 streams with sediment and nutrient problems may contain this community. Stream examples include: Dog, W.F. Poplar, Dry Wolf and Hanging Woman Creeks. Indicator taxa include: Corixidae, Cryptotendipes, Placobdella, Tubifex, Procladius, Cryptochironomus, Stempelinella 
Group 105 - Small Foothills Transitional Assemblage-This slightly unique community group (only 8 sample sites) is associated with medium-sized $\left(2^{\text {nd }}-4^{\text {th }}\right.$ order) foothills-montane (ecoregions 16 and17) cool-coldwater rivers with low forest cover but downstream from forested regions, low to moderate gradient (low enough to form depositional pools) of moderate elevation (4000-5200 ft). They may be slightly impacted by sediment or nutrients, but otherwise have a fairly intolerant community. Typically associated with B007 + C001 streams (Big Otter, Yellow Water Creek). Indicator taxa include: Helicopsyche borealis, Corynoneura, Constempellina, Prosimulium, Amiocentrus aspilis, Lara, Phaenopsectra, Plauditus, Narpus concolor 



\section{APPENDIX F. Fish SPECIES LIST AND STATUS FROM ALL SITES WITHIN THE DATABASE}





\begin{tabular}{|c|c|c|c|c|c|c|}
\hline Common Name & Scientific Name & $\begin{array}{c}\text { I- } \\
\text { Status }^{\mathrm{a}}\end{array}$ & $\begin{array}{c}\text { G- } \\
\text { Rank }\end{array}$ & $\begin{array}{c}\text { S- } \\
\text { Rank }\end{array}$ & $\begin{array}{c}\text { C- } \\
\text { Status }\end{array}$ & $\begin{array}{c}\text { US } \\
\text { FWS }^{\mathbf{c}}\end{array}$ \\
\hline Rock Bass & Ambloplites rupestris & IN & G5 & SNA & & \\
\hline Bullhead, Black & Ameiurus melas & IN & G5 & SNA & & \\
\hline Bullhead, Yellow & Ameiurus natalis & IN & G5 & SNA & & \\
\hline Freshwater Drum & Aplodinotus grunniens & $\mathrm{N}$ & G5 & S4 & & \\
\hline River Carpsucker & Carpiodes carpio & $\mathrm{N}$ & G5 & S5 & & \\
\hline Longnose Sucker & Catostomus catostomus & $\mathrm{N}$ & G5 & S5 & & \\
\hline White Sucker & Catostomus commersoni & $\mathrm{N}$ & G5 & S5 & & \\
\hline Mountain Sucker & Catostomus platyrhychus & $\mathrm{N}$ & G5 & S5 & & \\
\hline Mottled Sculpin & Cottus bairdi & $\mathrm{N}$ & G5 & S3 & & \\
\hline Lake Chub & Couesius plumbeus & $\mathrm{N}$ & G5 & S5 & & \\
\hline Brook Stickleback & Culaea inconstans & $\mathrm{N}$ & G5 & SU & & \\
\hline Blue Sucker & Cycleptus elongatus & $\mathrm{N}$ & G3G4 & S2S3 & SOC & \\
\hline Common Carp & Cyprinus carpio & EX & G5 & SNA & & \\
\hline Northern Pike & Esox lucius & N/IN & G5 & SNA & & \\
\hline Iowa Darter & Etheostoma exile & $\mathrm{N}$ & G5 & SU & SOR & \\
\hline Plains Killifish & Fundulus zebrinus & IN & G5 & S4 & & \\
\hline Western Mosquitofish & Gambusia affinis & EX & G5 & SNA & & \\
\hline Goldeneye & Hiodon alosoides & $\mathrm{N}$ & G5 & S5 & & \\
\hline Western Silvery Minnow & Hybognathus argyritis & $\mathrm{N}$ & G4 & S4 & & \\
\hline Brassy Minnow & Hybognathus hankinsoni & $\mathrm{N}$ & G4 & SU & SOR & \\
\hline Plains Minnow & Hybognathus placitus & $\mathrm{N}$ & G4 & SU & SOR & \\
\hline Channel Catfish & Ictalurus punctatus & $\mathrm{N}$ & G5 & S5 & & \\
\hline Smallmouth Buffalo & Ictiobus bubalus & $\mathrm{N}$ & G5 & S5 & & \\
\hline Bigmouth Buffalo & Ictiobus cyprinellus & $\mathrm{N}$ & G5 & S4 & & \\
\hline Shortnose Gar & Lepisosteus platostomus & $\mathrm{N}$ & G5 & S1 & SOC & \\
\hline Green Sunfish & Lepomis cyanellus & IN & G5 & SNA & & \\
\hline Pumpkinseed & Lepomis gibbosus & IN & G5 & SNA & & \\
\hline Burbot & Lota lota & $\mathrm{N}$ & G5 & SU & & \\
\hline Sturgeon Chub & Macrhybopsis gelida & $\mathrm{N}$ & G3 & S2 & SOC & \\
\hline Sicklefin Chub & Macrhybopsis meeki & $\mathrm{N}$ & G3 & S1 & SOC & \\
\hline Pearl Dace & Margariscus margarita & $\mathrm{N}$ & G5 & S2 & SOC & \\
\hline Smallmouth Bass & Micropterus dolomieu & IN & G5 & SNA & & \\
\hline Largemouth Bass & Micropterus salmoides & IN & G5 & SNA & & \\
\hline Shorthead Redhorse & Moxostoma macroledidotum & $\mathrm{N}$ & G5 & S5 & & \\
\hline Golden Shiner & Notemigonus crysoleucas & IN & G5 & S5 & & \\
\hline Emereld Shiner & Notropis atherinoides & $\mathrm{N}$ & G5 & S5 & & \\
\hline Spottail Shiner & Notropis hudsonius & IN & G5 & S5 & & \\
\hline Sand Shiner & Notropis stramineus & $\mathrm{N}$ & G5 & S5 & & \\
\hline Stonecat & Noturus flavus & $\mathrm{N}$ & G5 & S5 & & \\
\hline Golden Trout & Oncorynchus aquabonita & IN & G5 & SNA & & \\
\hline Yellowstone Cutthroat & Oncorynchus clarki bouvieri & $\mathrm{N}$ & G4T2 & S2 & SOC & \\
\hline Westslope Cutthroat Trout & Oncorynchus clarki lewisi & $\mathrm{N}$ & G4T3 & S2 & SOC & \\
\hline
\end{tabular}




\begin{tabular}{|c|c|c|c|c|c|c|}
\hline Rainbow Trout & Oncorynchus mykiss & IN & G5 & SNA & & \\
\hline Yellow Perch & Perca flavescens & IN & G5 & SNA & & \\
\hline Trout-perch & Percopsis omiscomaycus & $\mathrm{N}$ & G5 & S2 & \multirow{2}{*}{\multicolumn{2}{|c|}{ SOC }} \\
\hline Northern Redbelly Dace & Phoxinus eos & $\mathrm{N}$ & G5 & SU & & \\
\hline $\begin{array}{l}\text { Northern Redbelly Dace X Finescale } \\
\text { Dace }\end{array}$ & Phoxinus eos $x$ Phoxinus neogaeus & $\mathrm{N}$ & HYB & S3 & \multicolumn{2}{|l|}{ SOC } \\
\hline Fathead Minnow & Pimephales promelas & $\mathrm{N}$ & G5 & S5 & & \\
\hline Flathead Chub & Platygobio gracilis & $\mathrm{N}$ & G5 & S5 & & \\
\hline Paddlefish & Polyodon spathula & $\mathrm{N}$ & G4 & S1S2 & \multicolumn{2}{|l|}{ SOC } \\
\hline Crappie, White & Poxomis annularis & IN & G5 & SNA & & \\
\hline Crappie, Black & Poxomis nigromaculatus & IN & G5 & SNA & & \\
\hline Pygmy Whitefish & Prosopium coulteri & $\mathrm{N}$ & G5 & SU & & \\
\hline Mountian Whitefish & Prosopium williamsoni & $\mathrm{N}$ & G5 & S5 & & \\
\hline Longnose Dace & Rhinichthys cataractae & $\mathrm{N}$ & G5 & S5 & & \\
\hline Redside Shiner & Richardsonius balteatus & $\mathrm{N}$ & G5 & S5 & & \\
\hline Brown Trout & Salmo trutta & EX & G5 & SNA & & \\
\hline Bull Trout & Salvelinus confluentus & $\mathrm{N}$ & G3 & $\mathrm{S} 2$ & \multirow[t]{2}{*}{ SOC } & \multirow[t]{2}{*}{ LT } \\
\hline Brook Trout & Salvelinus fontinalis & IN & G5 & SNA & & \\
\hline Pallid Sturgeon & Scaphirhynchus albus & $\mathrm{N}$ & G1 & S1 & \multirow[t]{3}{*}{ SOC } & \multirow[t]{3}{*}{ LE } \\
\hline Shovelnose Sturgeon & Scaphirhynchus platorynchus & $\mathrm{N}$ & G5 & S5 & & \\
\hline Creek Chub & Semotilus atromaculatus & $\mathrm{N}$ & G5 & SU & & \\
\hline Sauger & Stizostedion canadense & $\mathrm{N}$ & G5 & S2 & \multicolumn{2}{|l|}{ SOC } \\
\hline Walleye & Stizostedion vitreum & IN & G5 & SNA & \multirow[b]{2}{*}{ SOC } & \multirow[b]{2}{*}{$\mathrm{C}$} \\
\hline Fluvial Arctic Grayling & Thymallus arcticus & $\mathrm{N}$ & $\mathrm{G} 5 / \mathrm{T} 1$ & $\mathrm{~S} 1$ & & \\
\hline \multicolumn{7}{|c|}{${ }^{\text {a }}$ Indigenous status- $\mathrm{N}=$ native, IN=introduced to MT, EX=exotic to the US } \\
\hline \multicolumn{7}{|c|}{ b State of Montana Conservation status- SOC= Species of Special Concern, SOR=Species on review } \\
\hline \multicolumn{7}{|c|}{$\begin{array}{l}{ }^{\mathrm{C}} \text { United States Fish and Wildlife Service Endangered Species List: LT=Listed Threatened, LE=Listed Endangered, } \\
\mathrm{C}=\text { Candidate species for listing }\end{array}$} \\
\hline
\end{tabular}




\section{APPENDIX G. UNMODIFIED OUTPUT CLASSIFICATION CLUSTER}

DENDROGRAM OF THE ALL SITES FISH DATABASE BASED ON CATEGORICAL ABUNDANCE 

FishspeciesAllsitesBry-curtis

Distance (Objective Function)

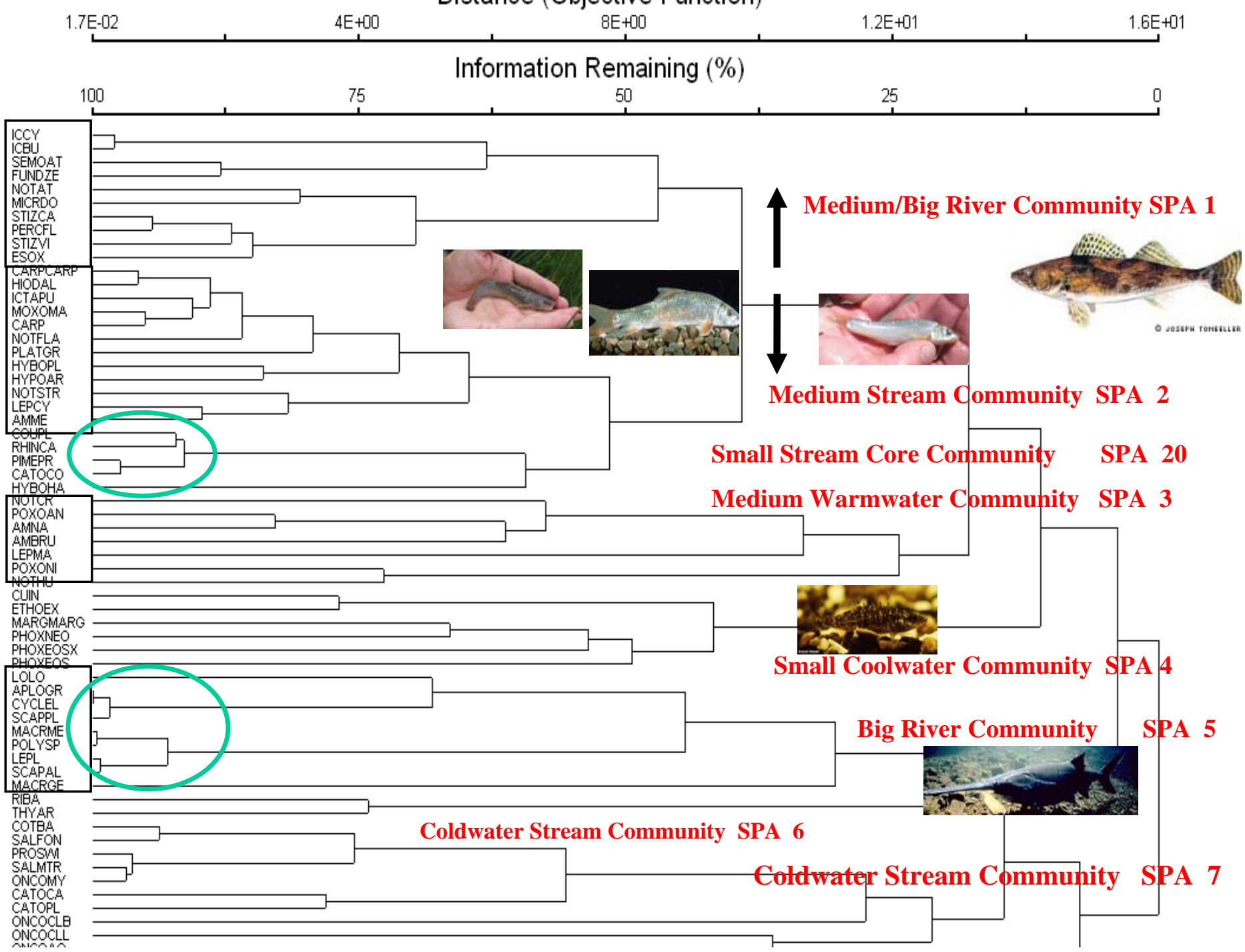



APPENDIX H. Fish COMMUNITY GROUP INDICATOR SPECIES RECORDED FROM ALL SITES WITHIN THE DATABASE 

Appendix H. Significant indicator species $(p<0.05)$ of the fish community groups. OIV =Observed Indicator Value of that taxon.

\begin{tabular}{|c|c|c|c|c|c|}
\hline Species Code & Group & OIV & Mean & St.Dev & $\mathbf{P}$-value \\
\hline HIODAL & 1 & 43.4 & 5 & 2.79 & 0.001 \\
\hline MOXOMA & 1 & 35.6 & 6.3 & 2.41 & 0.001 \\
\hline NOTAT & 1 & 35.5 & 4.6 & 2.66 & 0.001 \\
\hline ICTAPU & 1 & 31.1 & 5.5 & 2.75 & 0.001 \\
\hline STIZCA & 1 & 30.9 & 4.3 & 2.83 & 0.001 \\
\hline NOTFLA & 1 & 29.7 & 5.1 & 2.77 & 0.001 \\
\hline ESOX & 1 & 22.9 & 4.5 & 2.5 & 0.001 \\
\hline MICRDO & 1 & 14.9 & 4 & 2.59 & 0.011 \\
\hline ICBU & 1 & 10.8 & 3.4 & 2.68 & 0.023 \\
\hline STIZVI & 1 & 10.3 & 4 & 2.8 & 0.044 \\
\hline SEMOAT & 1 & 9.9 & 3.8 & 2.35 & 0.033 \\
\hline NOTCR & 1 & 9.4 & 3.1 & 2.17 & 0.02 \\
\hline ICCY & 1 & 8.6 & 3.2 & 2.71 & 0.027 \\
\hline FUNDZE & 1 & 6.1 & 3.3 & 2.31 & 0.08 \\
\hline PLATGR & 2 & 44 & 7.1 & 2.43 & 0.001 \\
\hline AMME & 2 & 39.9 & 5.7 & 2.54 & 0.001 \\
\hline CARPCARP & 2 & 38.5 & 5.3 & 2.61 & 0.001 \\
\hline CARP & 2 & 33.8 & 7.7 & 2.33 & 0.001 \\
\hline LEPCY & 2 & 30.6 & 5.2 & 2.36 & 0.001 \\
\hline NOTSTR & 2 & 26 & 6 & 2.61 & 0.003 \\
\hline HYPOAR & 2 & 20.1 & 5.5 & 2.68 & 0.003 \\
\hline HYBOPL & 2 & 16.9 & 6.1 & 2.58 & 0.007 \\
\hline PERCFL & 2 & 10 & 4.5 & 2.88 & 0.053 \\
\hline NOTHU & 2 & 2.1 & 3.3 & 2.29 & 0.58 \\
\hline AMNA & 3 & 13.1 & 3.2 & 2.53 & 0.017 \\
\hline POXOAN & 3 & 10.5 & 3.3 & 2.6 & 0.033 \\
\hline POXONI & 3 & 4.2 & 3.1 & 2.75 & 0.042 \\
\hline LEPMA & 3 & 3.7 & 2.5 & 2.44 & 0.175 \\
\hline LEPL & 3 & 2.2 & 2.4 & 2.39 & 0.407 \\
\hline AMBRU & 3 & 2.1 & 2.7 & 2.66 & 0.389 \\
\hline PHOXEOS & 4 & 16.9 & 3.8 & 2.76 & 0.007 \\
\hline MARGMARG & 4 & 8.9 & 3.1 & 2.7 & 0.01 \\
\hline PHOXEOSX & 4 & 5.1 & 3.1 & 2.47 & 0.017 \\
\hline PHOXNEO & 4 & 1.8 & 2.8 & 2.61 & 0.025 \\
\hline LOLO & 5 & 16.9 & 4 & 2.81 & 0.012 \\
\hline CYCLEL & 5 & 14.6 & 3.1 & 2.25 & 0.01 \\
\hline APLOGR & 5 & 10.1 & 2.9 & 2.31 & 0.007 \\
\hline SCAPAL & 5 & 1.1 & 2.2 & 2.01 & 0.05 \\
\hline
\end{tabular}




\begin{tabular}{lccccc}
\hline SCAPPL & 5 & 7.9 & 2.9 & 2.36 & 0.052 \\
MACRGE & 5 & 6.7 & 2.8 & 2.46 & 0.092 \\
POLYSP & 5 & 3.4 & 2.5 & 2.48 & 0.181 \\
MACRME & 5 & 2.2 & 2.4 & 2.43 & 0.417 \\
& & & & & \\
THYAR & 6 & 4.7 & 2.6 & 2.37 & 0.011 \\
RIBA & 6 & 1.6 & 2.3 & 2.19 & 0.026 \\
& & & & & \\
ONCOCLB & 7 & 93.9 & 3.3 & 2.61 & 0.001 \\
SALFON & 7 & 78.4 & 4.8 & 2.54 & 0.001 \\
COTBA & 7 & 39.7 & 4.5 & 2.68 & 0.001 \\
PROSWI & 7 & 35.5 & 4.3 & 2.64 & 0.001 \\
CATOPL & 7 & 30.8 & 5 & 2.38 & 0.001 \\
ONCOMY & 7 & 30.7 & 5.5 & 2.72 & 0.001 \\
ONCOCLL & 7 & 23 & 3.8 & 2.93 & 0.002 \\
CATOCA & 7 & 22.8 & 6.1 & 2.75 & 0.003 \\
SALMTR & 7 & 18.7 & 4.3 & 2.65 & 0.004 \\
ONCOAQ & 7 & 1.5 & 2.4 & 2.21 & 0.611 \\
& & & & & \\
COTTCO & 8 & 7.1 & 2.2 & 1.97 & 0.004 \\
SALCON & 8 & 7.1 & 2.2 & 1.97 & 0.004 \\
CUIN & 18 & 73.8 & 5.2 & 2.59 & 0.001 \\
HYBOHA & 18 & 13.8 & 5.7 & 2.48 & 0.02 \\
ETHOEX & 18 & 7.8 & 4.1 & 2.42 & 0.075 \\
CATOCO & 20 & 25 & 9.8 & 1.74 & 0.001 \\
PIMEPR & 20 & 22.6 & 9.7 & 1.95 & 0.001 \\
RHINCA & 20 & 21.2 & 8.4 & 2.18 & 0.001 \\
COUPL & 20 & 28 & 7.9 & 2.29 & 0.001 \\
\hline
\end{tabular}




\section{APPENDIX I. UNMODIFIED CLASSIFICATION DENDROGRAM OF THE YELLOWSTONE RIVER FISH DATABASE BASED ON CATEGORICAL ABUNDANCE}





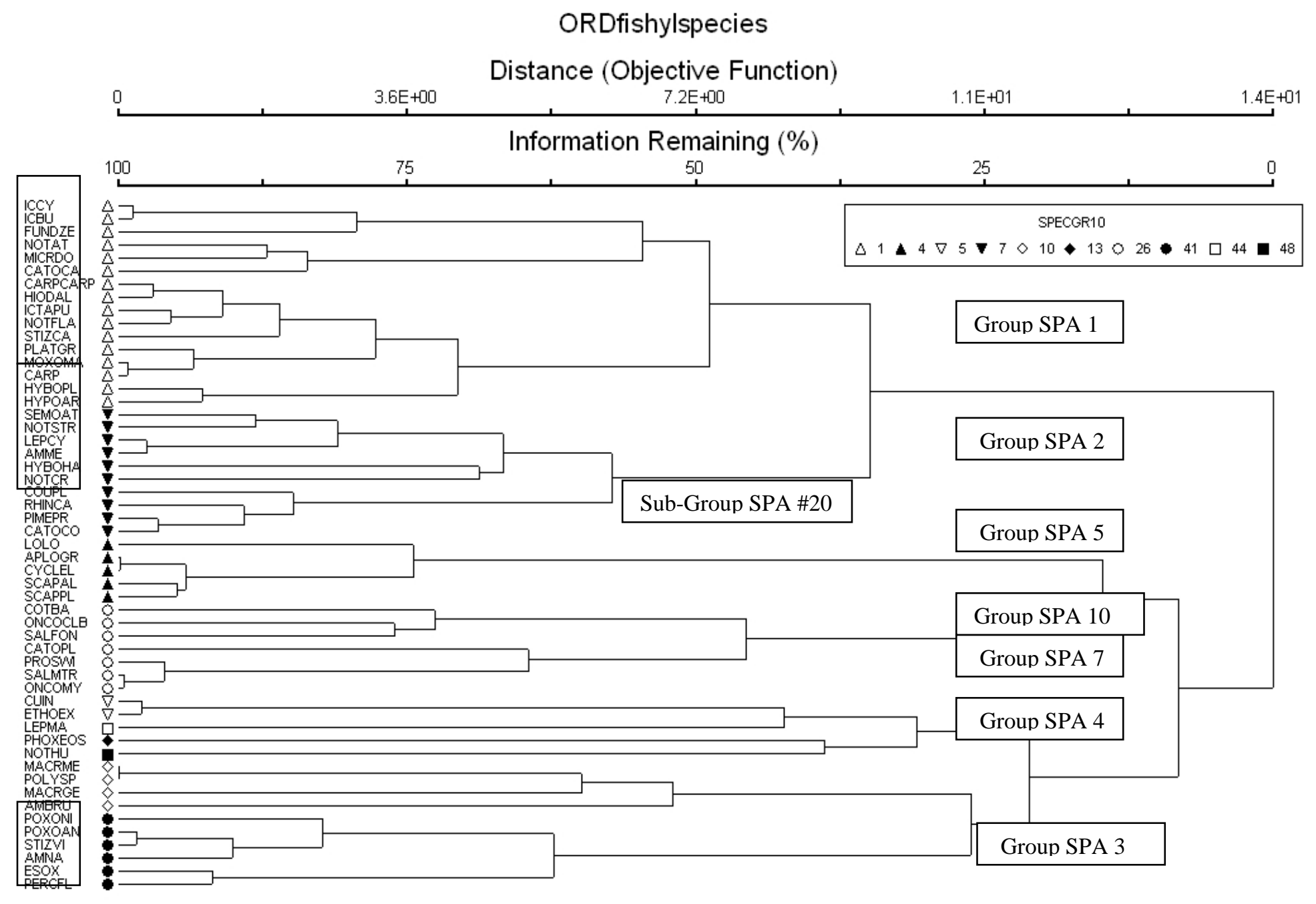





\section{APPENDIX J. UNMODIFIED OUTPUT OF THE FISH CLASSIFICATION CLUSTER DENDROGRAM FROM THE MISSOURI RIVER WATERSHED SITES}



FishLMsitesFLexBstats

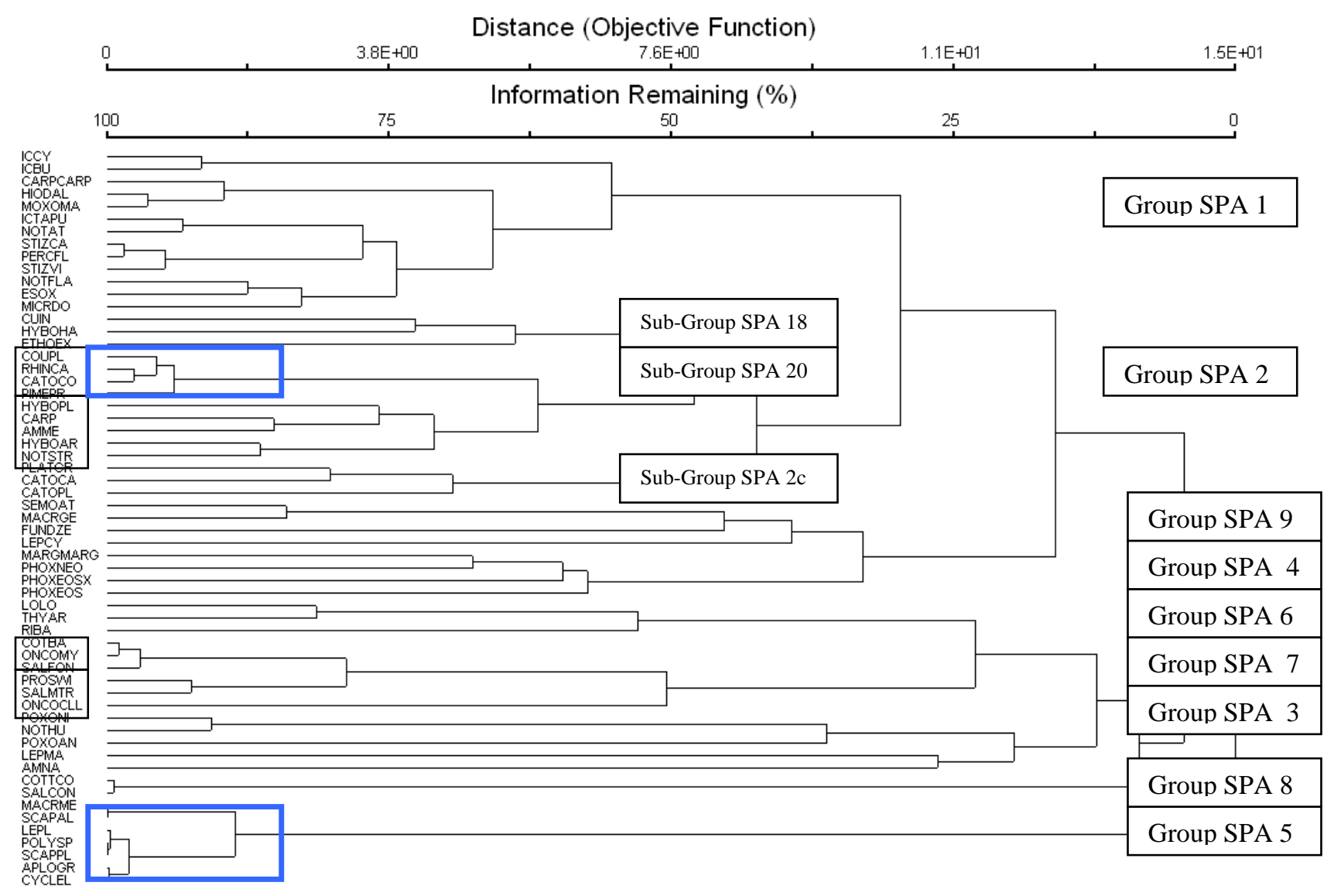





\section{Appendix K. Fish Community Group Descriptions}





\section{Description of Fish Communities}

\section{Medium-sized to Large River Communities $\left(3^{\text {rd- }} 7^{\text {th }}\right.$ order)}

Group SPA \#1-Large Warmwater River Assemblage-This community was dominated by larger, warmwater river fishes, including many of our natives, such as the sauger (Stizostedium canadanse), big (Ictiobus cyprinellus) and smallmouth buffalo (Ictiobus bubalus) and the emerald shiner (Notropis atherinoides), but also included fish species introduced to the Missouri and Yellowstone drainages: smallmouth bass (Micropterus dolomieu), perch (Perca flavescens), walleye (Stizostedium vitreum) and northern pike (Esox lucius). Warmwater generalists such as sunfish, bass and golden shiners are also closely associated with this group in the Yellowstone drainages. As a general rule this assemblage is found in larger, low gradient, glide-pool main branch streams $\left(4^{\text {th }}-6^{\text {th }}\right.$ order $)$ with an average summer temperature of $20-25^{\circ} \mathrm{C}$. The 2 native ictalurid species, the stonecat (Noturus flavus) and the channel catfish (Ictalurus punctatus), also cluster in this assemblage. This community can be found over a wide range of low-elevation landscapes within all three ecoregions of the study area, and is often associated with reservoirs, either upstream or downstream in the watershed.

Group SPA \#2- Medium Warmwater River Assemblage. Most of the medium to large warmwater river cyprinid species occur in this species assemblage (flathead chub, Platygobio gracilis; sand shiner, Notropis stramineus; plains minnow, Hybognathus placitus; western silvery minnow, Hybognathus argyritis), as well as the shorthead redhorse (Moxostoma macrolepidotum), river carpsucker (Carpiodes carpio), the exotic carp (Cyprinus carpio), the introduced green sunfish (Lepomis cyanellus) and black bullhead (Ameiurus melas). This species assemblage occurs in many of the Medium Prairie Rivers of Montana, the free-flowing, undamned sections of the Missouri River, and is the integral assemblage of the Powder River, which includes the MT species of concern Sturgeon Chub. The channel catfish and stonecat could easily co-occur within SPA 1 or 2 if proper habitat requirements are met, such as deep, side channel pools and large structures for hiding (large cobbles and woody debris).

Group SPA \# 20 -Core Prairie Stream Assemblage includes an assemblage of small native prairie fish that form the core community for perennial prairie streams (AES code C005 and C006) in both plains ecoregions. Included in this assemblage are the longnose dace (Rhinichthys cataractae), lake chub (Couesius plumbeus), fathead minnow (Pimephales notatus) and the white sucker (Catostomus commersoni). The lake chub and fathead minnow (Pimephales notatus) are species that occur in similar habitats of intermittent prairie stream systems D005 and D006, but in the Yellowstone drainages, you are more likely to get the lake chub as a single species intermittent pool member, and delineated out as the sole indicator species of Group SPA \#26 in those streams. As the small prairie streams dominated by this core species assemblage proceed downstream and increase stream order and linkages, they develop into the Medium Prairie River Community which includes the native plains and western silvery minnows (plains minnow is more tolerant of current, while the western silvery will be found in the protected silted 
side channels out of the current), and the sand shiner (in slower pools of B005 and B006 or larger streams with gravelly/sandy bottoms), and the exotic carp and introduced black bullhead.

Group SPA \#2c-Coolwater Transitional Fish Assemblage (Cool $\rightarrow$ Warmwater) (see SPA \#7 for additional description) contains the longnose (Catostomus catostomus) and mountain sucker (Catostomus platyrhychus) as an offshoot cluster. This indicates their affinity towards more transitional streams that contain stocked populations of rainbow and brown trout, further evidence of this can be found in the Yellowstone drainage dataset where these suckers typically are associated with the Traditional Trout Stream Assemblage. The stream sites associated with this transitional community were found throughout the state in primarily $3^{\text {rd }}-6^{\text {th }}$ order streams that maintain a cool summer temperature of $<20^{\circ} \mathrm{C}$ and found downstream from forested foothills and mountainous areas. The dominant species that defined this coolwater transitional community were longnose sucker, mountain sucker and longnose dace, in addition to white sucker (Catostomus commersoni), which is a relatively ubiquitious sucker species in eastern Montana. In the Yellowstone drainages

Group SPA \#3-Warmwater Sunfish Assemblage was dominated by a number of introduced reservoir and river game fish species that primarily occur in the larger B005 and B006, slow moving river tributaries of the Missouri and Yellowstone river drainages. This strange little community cluster of introduced and stocked fish, includes numerous sunfish (Pomoxis and Lepomis spp.), the rock bass (Ambloplites rupestris), yellow and black bullhead, and golden shiners. This community associated more closely with the other medium to large river warmwater species (Groups SPA \#1 and 2) in the Yellowstone drainage and didn't exist on its own as a community (Appendix G). The rock bass has only been reported in the Tongue River of the Yellowstone drainage probably from stocking in the Tongue River reservoir and thus is a fairly distinct member of this community, but is most associated with similar habitats to smallmouth bass (SPA \#1) as in other states (Zorn et. al. 1997).

Group SPA \#4 (Northern Redbelly Dace Assemblage-Coolwater community \#1) was dominated by a number of small stream fish species that primarily occur in the clear $2^{\text {nd }}-4^{\text {th }}$ order, C006 streams of the Missouri river drainages in the Northern Glaciated region of the state. These species include the Northern Redbelly Dace (Phoxinus eos), Northern Redbelly Dace hybrid (Phoxinus eos $x$ Phoxinus neogaeus), the Pearl Dace (Margariscus margarita) and a potential species in the state (found just across the Canadian border in the Frenchman and Poplar watersheds), the finescale dace (Phoxinus neogaeus). The pearl dace and the Northern Redbelly Dace hybrid (both MT Species of Concern) are the most sensitive to turbidity from siltation or riparian disturbance and will be the missing from this assemblage if stream conditions are impaired. Co-occurs with SPA \#18.

Group SPA \#5 (Large Mainstem Warmwater River Assemblage) is the warmwater fish community existing in the largest river systems (AES A001 and A002), dominated primarily by 2 sturgeon species: the shovelnose-Scaphirhynchus platorynchus and the federally threatened pallid-Scaphirhynchus albus), the freshwater drum (Aplodinotus grunniens), the burbot (Lota lota), the state threatened sturgeon (Macrhybopsis gelida) and sicklefin (Macrhybopsis meeki) chubs, and the blue sucker (Cycleptus elongatus). The Missouri mainstem contains 1 additional 
species than the Yellowstone, the shortnose gar (Lepisosteus platostomus) that has only been recorded downstream from Fort Peck dam. Large river communities include side-channel communities A001s and A002s (see Appendix K and L). Many of these species occur at the margins of the main current or in the quiet side channels and include: the emerald shiner, mooneye, sauger, flathead chub, longnose sucker, longnose dace, carp, white sucker, shorthead redhorse and sand shiner.

Montana's native coldwater stream and river fishes dominate Group SPA \#6, 8 and 10, while SPA \#7, included many of the introduced, non-native species, such as brook trout (Salvelinus fontinalis, brown trout (Salmo trutta) and rainbow trout (Oncorhynchus mykiss).

Group SPA \#6 (Big Hole Assemblage-Coldwater Community \#1) is characterized by the state-endangered fluvial arctic grayling (Thymallus arcticus) and redside shiner (Richardsonius balteatus). These species are restricted to the upper reaches of the Missouri in the Bighole River drainage, largely due to competition from introduced trout populations and degraded water quality downstream, but formerly ranged down to the Great Falls of the Missouri as reported by Lewis and Clark in June of 1805.

Group SPA \#7 (Traditional Trout Stream Assemblage)- indicated by the presence of brown trout, rainbow trout and the mountain whitefish (the latter species being the only native of this community), until you of proceed upstream into the $1^{\text {st }}$ and $2^{\text {nd }}$ order higher gradient streams of the mountains and transition to Sub-Group \#7a-Small Stream Coldwater Community \#2 which contains the Westslope Cutthroat Trout (Oncorynchus clarki lewisi) and the mottled sculpin (Cottus bairdi) in high quality streams or the Brook trout (Salvelinus fontinalis) in streams that are degraded or have been stocked. High gradient and upper elevation streams in the Yellowstone drainages transition from Group SPA \#7 to Group SPA \#10, unless degraded or stocked with brook trout.

Non-native trout dominate cold/ transitional community (Community SPA \#7). Streams where SPA \#7 dominates are very similar to the Transitional Community (Coolwater Community \#2) in terms of physical stream characteristics, with the main difference being that SPA \#7 is dominated by brown and rainbow trout. In fact, these two communities were most similar of the groups in terms of general species assemblage, and physical characteristics, leading one to believe that the presence of past or present trout stocking programs is the defining characteristic between these two groups.

Group SPA \#8 (Bull Trout Assemblage-Coldwater Community \#3)- indicated by the presence of Bull trout (Salvelinus confluentus) and slimy sculpin (Cottus cognatus) does not occur in the Missouri or Yellowstone drainages, but does occur mountainous streams of the western Columbia drainages and was included as an out-group to test the clustering.

Group SPA \#9 (Creek Chub Assemblage-Warmwater Community \#4) was dominated by the creek chub (Semotilus atromaculatus) and includes the introduced species, green sunfish, and plains killifish (Fundulus zebrinus). In the Missouri drainages, this group is limited to the Little Missouri River, which flows into North Dakota, and then to the Missouri River. Although the sturgeon chub is included in this group within the Yellowstone drainages, it makes more 
ecological sense to be included within the SPA \#5 in the Missouri drainage and SPA \#2 for the Yellowstone drainages, especially the Powder River (A003) assemblage. Group SPA \#9 can best be understood by looking at the ecological characteristics of the member species: the creek chub and the plains killifish are tolerant fish and generalist feeders that can utilize a wide array of conditions, persist in high-order streams, and are quite pollution and turbidity tolerant. The creek chub does prefer to spawn in gravelly, current areas, so this may be a limiting factor in its distribution in some low gradient silted prairie streams. This group's tolerance to turbidity and salinity explains its presence in some of the highly conductive streams in southeastern MT including the Tongue and Powder River drainages and in the Prairie-Elk Drainages of the Missouri. This species assemblage, especially the plains killifish may actually increase in abundance and be an indicator species of degraded conditions within streams influenced by coalbed methane effluent, which can significantly increase the conductivity of the downstream waters.

Group SPA \#10 (Yellowstone Trout Assemblage)- indicated by the presence of Yellowstone cutthroat trout and mottled sculpin, and may include the presence of Golden trout (introduced), which occur only in the high elevation, cold streams of the Yellowstone drainages.

Group SPA \#18 (Brook Stickleback Assemblage-Coolwater community \#1)-includes the brook stickleback (Culaea inconstans), brassy minnow (Hybognathus hankinsoni) and Iowa Darter (Etheostoma exile). This species assemblage is found most commonly associated with small Northern Glaciated prairie streams (AES C006 and D006) with relatively clear water, large pools and vegetative cover. 


\section{APPENDIX L. LIST OF SPECIES GROUP ASSEMBLAGES (SPA) AND GROUP MEMBERSHIP FOR THE MONTANA'S MISSOURI WARM-WATER DRAINAGES AND THE PREDICTED COMMUNITIES BASED ON AES AND HABITAT CRITERIA}



Appendix L. List of species group assemblages (SPA) and group membership for the Montana's Missouri warm-water drainages and the predicted communities based on AES criteria. An asterisk $\left(^{*}\right)$ after the common name represents an Indicator Species for that assemblege and an $(\mathbf{X})$ indicates the species presence in the community, a (XX) indicates a dominant member (by percentage of individuals) and $\mathrm{a}(\mathrm{x})$ indicates a rare occurrence.

\begin{tabular}{|c|c|c|c|c|c|c|c|c|c|c|c|c|c|c|c|}
\hline Common Name & SPA & A001 ${ }^{a}$ & $A 001 s^{b}$ & $A 003^{c}$ & $A 004^{d}$ & $\begin{array}{c}\mathrm{B} 006 \\
\mathrm{a}^{*}\end{array}$ & $\begin{array}{c}\text { B006 } \\
b^{* * *}\end{array}$ & $\begin{array}{l}\text { B006 } \\
\mathrm{c}^{* * *}\end{array}$ & $\begin{array}{c}\text { B006 } \\
\text { d\# }\end{array}$ & $\begin{array}{c}\mathrm{C} 006 \\
\mathrm{a}^{*}\end{array}$ & $\begin{array}{c}\mathrm{C} 006 \\
\mathbf{b}^{* * *}\end{array}$ & $\begin{array}{l}\mathrm{C} 006 \\
\mathrm{c}^{* * *}\end{array}$ & $\begin{array}{c}\mathrm{C} 006 \\
\mathrm{~d} \#\end{array}$ & $\begin{array}{c}\mathrm{D} 006 \\
\mathrm{a}^{*}\end{array}$ & $\begin{array}{c}\text { D006 } \\
\text { d\# }\end{array}$ \\
\hline Bigmouth buffalo & 1 & $\bar{X}$ & $\bar{X}$ & & $\bar{X}$ & & & $\bar{X}$ & & & & & & & \\
\hline Northern pike & 1 & $x$ & $x$ & & $x$ & & & $x$ & $X$ & & & $X$ & $x$ & & \\
\hline Sauger * & 1 & $X$ & $x$ & & $x$ & & & $x$ & & & & $x$ & & & \\
\hline Smallmouth bass & 1 & 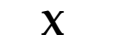 & $x$ & & $x$ & & & & & & & $x$ & & & \\
\hline Smallmouth buffalo & 1 & $x$ & $X$ & & $x$ & & & $x$ & & & & & & & \\
\hline Stonecat * & 1 & $x$ & $x$ & $x$ & $x$ & $x$ & $x$ & $x$ & & $x$ & $x$ & $X$ & & & \\
\hline Channel catfish * & 1 & $x$ & $X$ & $x$ & $x$ & $x$ & $x$ & $\mathrm{X}$ & 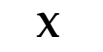 & $x$ & $x$ & $X$ & & & \\
\hline Walleye & 1 & $x$ & $x$ & & $x$ & $x$ & $x$ & $x$ & & & & & & & \\
\hline Yellow perch & 1 & & $x$ & & $x$ & & $x$ & $x$ & $x$ & & & $x$ & & & \\
\hline Emerald shiner * & 1 & $x$ & $X X$ & & $x$ & & & $x$ & & & & & & & \\
\hline Creek chub & $9^{*}$ & & & $x$ & & & & & & & & & & & \\
\hline Plains Killifish & 9 & & & $x$ & & & & & & & & & & & \\
\hline Goldeye * & $1^{*}$ & $X X$ & $X X$ & $x$ & $x$ & & & $x$ & & & & $x$ & & & \\
\hline River carpsucker * & $1^{*}$ & $x$ & $X X$ & $x$ & $x$ & $x$ & $x$ & $x$ & & & & & & & \\
\hline Shorthead Redhorse * & $1^{*}$ & $x$ & $x$ & $x$ & $x$ & $x$ & $x$ & $x$ & $x$ & $x$ & & $x$ & & & \\
\hline Common carp & 2 & $x$ & $x$ & $x$ & $x$ & $x$ & $x$ & $x$ & $x$ & $x$ & $\mathbf{x}$ & $x$ & $x$ & & \\
\hline Flathead Chub * & 2 & $x$ & $X X$ & $x$ & $x$ & $X X$ & $x$ & $x$ & $x$ & $x$ & $x$ & $x$ & & & \\
\hline Green sunfish & 2 & & & $x$ & & & $x$ & & & & & & & & \\
\hline Plains minnow * & 2 & $x$ & $x$ & $x$ & $x$ & $x$ & $x$ & $x$ & $x$ & $x$ & $x$ & $x$ & & & \\
\hline Sand shiner * & 2 & $x$ & $X X$ & $\mathrm{X}$ & $\mathrm{X}$ & $X X$ & $\mathbf{x}$ & $\mathbf{x}$ & $x$ & $x$ & $x$ & $x$ & & & \\
\hline Black bullhead & 2 & & & $x$ & $x$ & $X$ & $x$ & $x$ & $x$ & $x$ & $x$ & $x$ & $X X$ & & \\
\hline Spottail shiner & 3 & & & & $x$ & & & $x$ & & & & & & & \\
\hline
\end{tabular}




\begin{tabular}{|c|c|c|c|c|c|c|c|c|c|c|c|c|c|c|c|}
\hline Common Name & SPA & $\mathrm{A} 001^{\mathrm{a}}$ & A001s ${ }^{b}$ & $A 003^{c}$ & $A 004^{d}$ & $\begin{array}{c}\text { B006 } \\
a^{*}\end{array}$ & $\begin{array}{c}\text { B006 } \\
b^{* *}\end{array}$ & $\begin{array}{l}\mathrm{B} 006 \\
\mathrm{C}^{* * *}\end{array}$ & $\begin{array}{c}\text { B006 } \\
\text { d\# }\end{array}$ & $\begin{array}{c}\mathrm{C} 006 \\
\mathrm{a}^{*}\end{array}$ & $\begin{array}{c}\mathrm{C} 006 \\
\mathbf{b}^{* *}\end{array}$ & $\begin{array}{c}\mathrm{C} 006 \\
\mathrm{c}^{* * *}\end{array}$ & $\begin{array}{c}\mathrm{C} 006 \\
\mathrm{~d} \#\end{array}$ & $\begin{array}{c}\mathrm{D} 006 \\
\mathrm{a}^{*}\end{array}$ & $\begin{array}{c}\mathrm{D} 006 \\
\mathrm{~d} \#\end{array}$ \\
\hline Western silvery minnow & 2 & & $\mathbf{X X}$ & $X$ & $X$ & $X$ & $X$ & $X$ & $X$ & $x$ & $x$ & $X$ & & & \\
\hline Longnose sucker & 2 & $X$ & & & & $x$ & & $x$ & & & & & & & \\
\hline Mountain sucker & 2 & $X$ & & & & & & & & & & & & & \\
\hline Fathead minnow * & 20 & & $X$ & $X$ & $X$ & $X$ & $X X$ & $X$ & $X X$ & $\mathbf{X}$ & $X$ & $X$ & $X X$ & $X X$ & $X X$ \\
\hline Longnose dace & 20 & $X$ & $X X$ & $X$ & $X$ & $X$ & $X$ & $X$ & & $X X$ & $X$ & $X$ & & & \\
\hline White sucker * & 20 & $X$ & $X$ & $X$ & $X$ & $X$ & $X$ & $X$ & $X$ & $X$ & $X$ & $X$ & $X$ & & \\
\hline Lake chub* & 20 & & & & & $x$ & $x$ & & $x$ & $X$ & $X$ & $X$ & $x$ & & \\
\hline Bluegill & 3 & & & & & & & & & & & & & & \\
\hline Golden shiner & 3 & & & & & & & & & & & & & & \\
\hline Largemouth bass & 3 & & & & & & & & & & & & & & \\
\hline Pumpkinseed & 3 & & $x$ & & $x$ & & & $x$ & & & & & & & \\
\hline Yellow bullhead & 3 & & & & & & & & & & & & & & \\
\hline Brook stickleback* & 18 & & & & & $x$ & $x$ & & & $X$ & $X$ & $x$ & $x$ & $X X$ & \\
\hline Iowa darter & 18 & & & $X$ & & $X$ & $x$ & & $x$ & $X$ & $x$ & $x$ & $x$ & $x$ & \\
\hline Brassy minnow & 18 & & & & & $X$ & & & $x$ & $X$ & $X$ & $X$ & $X$ & $X$ & \\
\hline Northern redbelly dace* & 4 & & & & & & & & & $X$ & $X$ & $X$ & & $X$ & \\
\hline $\begin{array}{l}\text { Northern redbelly dace } X \\
\text { Finescale dace }\end{array}$ & 4 & & & & & & & & & $x$ & $x$ & & & & \\
\hline Finescale Dace & 4 & & & & & & & & & $x$ & & & & & \\
\hline Pearl dace* & 4 & & & & & $X$ & & & & $x$ & $x$ & $x$ & & & \\
\hline Blue sucker * & 5 & $X$ & $x$ & & & & & & & & & & & & \\
\hline Burbot & 6 & $X$ & $X$ & & & & & & & & & & & & \\
\hline Freshwater drum * & 5 & $X$ & $X$ & & & & & & & & & & & & \\
\hline Paddlefish * & 5 & $X$ & & & & & & & & & & & & & \\
\hline Pallid sturgeon * & 5 & $x$ & & & & & & & & & & & & & \\
\hline Shortnose gar & 5 & $x$ & & & & & & & & & & & & & \\
\hline
\end{tabular}




\begin{tabular}{|c|c|c|c|c|c|c|c|c|c|c|c|c|c|c|c|}
\hline Common Name & SPA & A001 & A001s & A003 & A004 & $\begin{array}{c}\text { B006 } \\
\mathbf{a}^{*}\end{array}$ & $\begin{array}{c}\text { B006 } \\
\mathbf{b}^{* *}\end{array}$ & $\begin{array}{c}\text { B006 } \\
\mathbf{c}^{* * *}\end{array}$ & $\begin{array}{c}\text { B006 } \\
\mathbf{d} \#\end{array}$ & $\begin{array}{c}\text { C006 } \\
\mathbf{a}^{*}\end{array}$ & $\begin{array}{c}\text { C006 } \\
\mathbf{b}^{* *}\end{array}$ & $\begin{array}{c}\text { C006 } \\
\mathbf{c}^{* * *}\end{array}$ & $\begin{array}{c}\text { C006 } \\
\mathbf{d} \#\end{array}$ & $\begin{array}{c}\text { D006 } \\
\mathbf{a}^{*}\end{array}$ & $\begin{array}{c}\text { D006 } \\
\mathbf{d} \#\end{array}$ \\
\hline
\end{tabular}

Shovelnose sturgeon *

Sturgeon chub *

Sicklefin Chub *

$\begin{array}{ll}5 & X \\ 9 & \mathrm{x} \\ 5 & \mathrm{x}\end{array}$

Total \# Common Native

Species

25

$10 \quad 13$

$16 \quad 15$

a A001 Main-Stem Missouri below Great Falls

b A001s Missouri side-channel/pool community

c A003 Little Missouri

d A004 Milk / Marias

* a stream $>5$ miles from the confluence with the full complement of habitats (large woody debris/undercut banks/riffles/gravel)

**b stream without riffles/gravel and mostly continuous deep pools with large woody debris/undercut banks

${ }^{* * *} \mathrm{c}$ stream within 5 connected river miles of the confluence of the Missouri R. community

\#d stream with degraded habitat conditions or overrun with non-native species 



\section{APPENDIX M. LiST OF SPECIES GROUP ASSEMbLAGES (SPA) AND GROUP MEMBERSHIP FOR THE MONTANA'S YELLOWSTONE}

WARM-WATER DRAINAGES AND THE PREDICTED COMMUNITIES BASED ON AES AND HABITAT CRITERIA 

Appendix M. List of species group assemblages (SPA) and group membership for the Montana's Yellowstone warm-water drainages and the predicted communities based on AES. An asterisk (*) after the common name represents an Indicator Species for that assemblage and an $(\mathbf{X})$ indicates the species presence in the community, a (XX) indicates a dominant member (by percentage of individuals), and a $(\mathrm{x})$ indicates a rare occurrence.

\begin{tabular}{|c|c|c|c|c|c|c|c|c|c|c|c|c|c|c|c|c|}
\hline Common Name & SPA & $\mathrm{A} 002^{\mathrm{a}}$ & $A 002 s^{b}$ & $A 003^{c}$ & $A 003 u^{\$}$ & B005 $\mathrm{a}^{*}$ & $\begin{array}{c}\text { B005 } \\
\mathbf{b}^{* *}\end{array}$ & $\begin{array}{l}\text { B005 } \\
\mathrm{c}^{* * *}\end{array}$ & $\begin{array}{c}\text { B005 } \\
\text { d\# }\end{array}$ & C001 & $\begin{array}{c}\mathrm{C} 005 \\
\mathrm{a}^{*}\end{array}$ & $\begin{array}{c}\mathrm{C} 005 \\
\mathbf{b}^{* *}\end{array}$ & $\begin{array}{c}\mathrm{C} 005 \\
\mathrm{c}^{* * *}\end{array}$ & $\begin{array}{c}\mathrm{C} 005 \\
\mathrm{~d} \#\end{array}$ & $\begin{array}{c}\mathrm{D} 005 \\
\mathrm{a}^{*}\end{array}$ & $\begin{array}{c}\mathrm{D} 005 \\
\mathrm{~d} \#\end{array}$ \\
\hline Bigmouth buffalo & 1 & $X$ & $X$ & $X$ & & & & $X$ & & & & & & & & \\
\hline Northern pike & 1 & & $x$ & & & & & $x$ & $X$ & & & & $x$ & $X$ & & \\
\hline Sauger * & 1 & $X$ & $x$ & $X$ & $x$ & & $x$ & $X$ & & & & & $x$ & & & \\
\hline Smallmouth bass & 1 & $X$ & $x$ & $x$ & & & & & & & & & & & & \\
\hline Smallmouth buffalo & 1 & $x$ & $X$ & $X$ & & & & $X$ & & & & & & & & \\
\hline Stonecat * & 1 & $x$ & $X$ & $X$ & $X$ & $X$ & & $X$ & & & $X$ & & & & & \\
\hline Channel catfish * & 1 & $X$ & $X$ & $X$ & $X$ & $X$ & $X$ & $X$ & $X$ & $X$ & $X$ & & & & & \\
\hline Walleye & 1 & $X$ & $X$ & $X$ & $x$ & $x$ & & $X$ & & & & & & & & \\
\hline Yellow perch & 1 & & $x$ & $x$ & & $x$ & & & $x$ & & & & & & & \\
\hline Emerald shiner * & 1 & $X$ & $X X$ & $X$ & & & & $x$ & & & & & $x$ & & & \\
\hline Creek chub & 9* & & & $x$ & $x$ & $X$ & $X$ & & & & & & & & & \\
\hline Plains Killifish & 9 & & & $x$ & $x$ & $x$ & $X$ & & & & & & & & & \\
\hline Goldeye * & $1^{*}$ & $X X$ & $X X$ & $X$ & $X$ & & & $X$ & & & & & & & & \\
\hline River carpsucker * & $1^{*}$ & $x$ & $X X$ & $X$ & $X$ & $X$ & & $X$ & & & & & & & & \\
\hline Shorthead Redhorse * & $1^{*}$ & $X$ & $\mathbf{x}$ & $X$ & $X$ & $X$ & $X$ & $X$ & $X$ & $X$ & $x$ & $x$ & $x$ & & & \\
\hline Common carp & 2 & $x$ & $X$ & $X$ & $X$ & $X$ & $X$ & $X$ & $X$ & $X$ & $X$ & $X$ & $X$ & & & \\
\hline Flathead Chub * & 2 & $X$ & $X X$ & $X X$ & $X X$ & $X$ & & $X$ & & $X$ & $X$ & $X$ & $X$ & & & \\
\hline Green sunfish & 2 & & & $X$ & $x$ & $X$ & $X$ & & & & & & & & & \\
\hline Plains minnow * & 2 & $X$ & $X$ & $X$ & $X$ & $X$ & $X$ & $X$ & $X$ & $X$ & $X$ & $X$ & $X$ & & & \\
\hline
\end{tabular}




\begin{tabular}{|c|c|c|c|c|c|c|c|c|c|c|c|c|c|c|c|c|}
\hline Common Name & SPA & $\mathrm{A} 002^{\mathrm{a}}$ & $\mathrm{A} 002 \mathrm{~s}^{\mathrm{b}}$ & $\mathrm{A}^{003^{c}}$ & A003 $u^{\$}$ & B005 $a^{*}$ & $\begin{array}{c}\text { B005 } \\
\mathbf{b}^{* *}\end{array}$ & $\begin{array}{l}\mathrm{B} 005 \\
\mathrm{c}^{* * *}\end{array}$ & $\begin{array}{c}\text { B005 } \\
\text { d\# }\end{array}$ & Co01 & $\begin{array}{c}\mathrm{C} 005 \\
\mathrm{a}^{*}\end{array}$ & $\begin{array}{c}\mathrm{C} 005 \\
\mathbf{b}^{* *}\end{array}$ & $\begin{array}{l}\mathrm{C} 005 \\
\mathrm{c}^{* * *}\end{array}$ & $\begin{array}{c}\mathrm{C} 005 \\
\mathrm{~d} \#\end{array}$ & $\begin{array}{c}\text { D005 } \\
\mathbf{a}^{*}\end{array}$ & $\begin{array}{c}\mathrm{D} 005 \\
\mathrm{~d} \#\end{array}$ \\
\hline Sand shiner * & 2 & $x$ & $X X$ & $X X$ & $X X$ & $\mathbf{X}$ & $\mathbf{X}$ & $\mathbf{X}$ & $\mathbf{X}$ & & $\mathbf{X}$ & $\mathbf{X}$ & $X$ & & & \\
\hline Black bullhead & 2 & & & $x$ & $x$ & $x$ & $\mathrm{X}$ & $\mathrm{X}$ & $\mathrm{X}$ & & $\mathrm{X}$ & $\mathrm{X}$ & $\mathrm{X}$ & & & \\
\hline Spottail shiner & 3 & & & & & & & & & & & & & & & \\
\hline Western silvery minnow & 2 & & $X X$ & $X X$ & $\mathbf{x}$ & $\mathrm{X}$ & $\mathrm{X}$ & $\mathrm{X}$ & $\mathrm{X}$ & $X$ & $x$ & $x$ & $\mathrm{X}$ & & & \\
\hline Longnose sucker & 2 & $X$ & & & & & & & & $\mathbf{X}$ & & & & & & \\
\hline Mountain sucker & 2 & $X$ & & & & & & & & $x$ & & & & & & \\
\hline Fathead minnow * & 20 & & $\mathbf{X}$ & $x$ & & $X$ & $\mathrm{X}$ & & $\mathbf{X}$ & $X$ & $x$ & $X$ & $x$ & $X X$ & $x$ & \\
\hline Longnose dace & 20 & $\mathrm{X}$ & $X X$ & $\mathrm{X}$ & $\mathrm{x}$ & $\mathrm{X}$ & & & & $X$ & $\mathrm{X}$ & $X$ & $X$ & & & \\
\hline White sucker * & 20 & $\mathrm{X}$ & $x$ & $x$ & $X$ & $\mathrm{X}$ & $\mathrm{X}$ & $\mathrm{X}$ & $\mathrm{X}$ & $X$ & $\mathrm{X}$ & $X$ & $\mathrm{X}$ & $x$ & & \\
\hline Lake chub * & 20 & & & & & $x$ & $\mathrm{X}$ & & $\mathrm{X}$ & & $\mathrm{X}$ & $X$ & $x$ & $x$ & $\mathrm{X}$ & $X X$ \\
\hline Bluegill & 3 & & & & & & & & & & & & & & & \\
\hline Golden shiner & 3 & & & & & & & & & & & & & & & \\
\hline Largemouth bass & 3 & & & & & & & & & & & & & & & \\
\hline Pumpkinseed & 3 & & & & & & & & & & & & & & & \\
\hline Rock bass & 3 & & & & & & & & & & & & & & & \\
\hline Yellow bullhead & 3 & & & & & $x$ & & & & & & & & & & \\
\hline Brook stickleback* & 18 & & & & & $x$ & $\mathrm{X}$ & & & & $\mathrm{X}$ & $X$ & $X$ & $x$ & $X X$ & \\
\hline Iowa darter & na & & & & & & & & & & & & & & & \\
\hline Brassy minnow & 18 & & & & & $x$ & $\mathrm{X}$ & & & & $\mathrm{X}$ & $X$ & $X$ & $\mathrm{X}$ & $\mathrm{X}$ & \\
\hline Northern redbelly dace* & 4 & & & & & & & & & & $\mathrm{X}$ & $X$ & $\mathrm{X}$ & & & \\
\hline $\begin{array}{l}\text { Northern redbelly dace X } \\
\text { Finescale dace }\end{array}$ & 4 & & & & & & & & & & & & & & & \\
\hline Finescale Dace & 4 & & & & & & & & & & & & & & & \\
\hline Pearl dace* & 4 & & & & & & & & & & & & & & & \\
\hline Blue sucker * & 5 & $x$ & $x$ & & & & & & & & & & & & & \\
\hline Burbot & 6 & $X$ & $X$ & $X$ & & & & & & & & & & & & \\
\hline
\end{tabular}




\begin{tabular}{|c|c|c|c|c|c|c|c|c|c|c|c|c|c|c|c|c|}
\hline Common Name & SPA & A002 ${ }^{a}$ & $\mid \mathrm{A} 002 \mathrm{~s}^{\mathrm{b}}$ & A003c & $\mathrm{A} 003 \mathrm{u}^{\$}$ & B005 a* & $\begin{array}{c}\text { B005 } \\
\mathbf{b}^{* *}\end{array}$ & $\begin{array}{l}\text { B005 } \\
\text { c }^{* * *}\end{array}$ & $\begin{array}{c}\text { B005 } \\
\text { d\# }\end{array}$ & C001 & $\begin{array}{c}\mathrm{C} 005 \\
\mathrm{a}^{*}\end{array}$ & $\begin{array}{c}\mathbf{C} 005 \\
\mathbf{b}^{* *}\end{array}$ & $\begin{array}{l}\mathrm{C} 005 \\
\mathrm{c}^{* * * *}\end{array}$ & $\begin{array}{c}\mathrm{C} 005 \\
\mathrm{~d} \#\end{array}$ & $\begin{array}{c}\text { D005 } \\
\mathbf{a}^{*}\end{array}$ & $\begin{array}{c}\text { D005 } \\
\text { d\# }\end{array}$ \\
\hline
\end{tabular}

Freshwater drum *

Paddlefish *

Pallid sturgeon *

Shortnose gar

Shovelnose sturgeon *

Sturgeon chub *

Sicklefin Chub *

$\begin{array}{lllll}5 & X & X & X & \\ 5 & X & & & \\ 5 & X & & & \\ 5 & X & & & \\ 5 & X & & X & \\ 9 & x & & X & X \\ 5 & x & & & \end{array}$

\begin{tabular}{|llllllllllllllll}
\hline Total Native Species & 5 & 10 & 20 & 12 & 16 & 12 & 14 & 8 & 10 & 15 & 12 & 12 & 5 & 2 & 1 \\
\hline
\end{tabular}

a A002 Main-Stem Yellowstone River below Billings

b Yellowstone side-channel/pool community

c A003-Powder River downstream Broadus

\$ A003u-Powder River upstream Broadus

* a stream $>5$ miles from the confluence with the full complement of habitats (large woody debris/undercut banks/riffles/gravel)

${ }^{* *} \mathrm{~b}$ stream without riffles/gravel and mostly continuous deep pools with large woody debris/undercut banks

${ }^{* * *} \mathrm{C}$ stream within 5 connected river miles of the confluence of the Yellowstone R. community

\#d stream with degraded habitat conditions or overrun with non-native species

na- found only in one small tributary to the Yellowstone River (Lone Tree Creek) 



\section{Appendix N. Global/State Rank Definitions}





\section{Heritage Program Ranks}

The international network of Natural Heritage Programs employs a standardized ranking system to denote global (range-wide) and state status. Species are assigned numeric ranks ranging from 1 to 5 , reflecting the relative degree to which they are "at-risk". Rank definitions are given below. A number of factors are considered in assigning ranks - the number, size and distribution of known "occurrences" or populations, population trends (if known), habitat sensitivity, and threat. Factors in a species' life history that make it especially vulnerable are also considered (e.g., dependence on a specific pollinator).

Global Rank Definitions (NatureServe 2003)

G1 Critically imperiled because of extreme rarity and/or other factors making it highly vulnerable to extinction

G2 Imperiled because of rarity and/or other factors making it vulnerable to extinction

G3 Vulnerable because of rarity or restricted range and/or other factors, even though it may be abundant at some of its locations

G4 Apparently secure, though it may be quite rare in parts of its range, especially at the periphery

G5 Demonstrably secure, though it may be quite rare in parts of its range, especially at the periphery

T1-5 Infraspecific Taxon (trinomial) — The status of infraspecific taxa (subspecies or varieties) are indicated by a “T-rank” following the species' global rank

\section{STATE RANK DEFinITIONS}

S1

S2

S3

S4

S5

At high risk because of extremely limited and potentially declining numbers, extent and/or habitat, making it highly vulnerable to extirpation in the state At risk because of very limited and potentially declining numbers, extent and/or habitat, making it vulnerable to extirpation in the state

Potentially at risk because of limited and potentially declining numbers, extent and/or habitat, even though it may be abundant in some areas

Uncommon but not rare (although it may be rare in parts of its range), and usually widespread. Apparently not vulnerable in most of its range, but possibly cause for long-term concern Common, widespread, and abundant (although it may be rare in parts of its range). Not vulnerable in most of its range

\section{Combination RANKS}

G\#G\# or S\#S\# Range Rank-A numeric range rank (e.g., G2G3) used to indicate uncertainty about the exact status of a taxon

QUALIFIERS

NR Not ranked this entity as a taxon at the current level is questionable; resolution of this uncertainty may result in change from a species to a subspecies or hybrid, or inclusion of this taxon in another taxon, with the resulting taxon having a lower-priority (numerically higher) conservation status rank 
Presumed Extinct-Species believed to be extinct throughout its range. Not located despite intensive searches of historical sites and other appropriate habitat, and virtually no likelihood that it will be rediscovered

Possibly Extinct-Species known from only historical occurrences, but may never-theless still be extant; further searching needed

Unrankable - Species currently unrankable due to lack of information or due to substantially conflicting information about status or trends

Hybrid —Entity not ranked because it represents an interspecific hybrid and not a species

Inexact Numeric Rank-Denotes inexact numeric rank

$\mathrm{C}$

Captive or Cultivated Only-Species at present is extant only in captivity or cultivation, or as a reintroduced population not yet established

Accidental-Species is accidental or casual in Montana, in other words, infrequent and outside usual range. Includes species (usually birds or butterflies) recorded once or only a few times at a location. A few of these species may have bred on the one or two occasions they were recorded

Z

Zero Occurrences-Species is present but lacking practical conservation concern in Montana because there are no definable occurrences, although the taxon is native and appears regularly in Montana

Potential-Potential that species occurs in Montana but no extant or historic occurrences are accepted

R Reported - Species reported in Montana but without a basis for either accepting or rejecting the report, or the report not yet reviewed locally. Some of these are very recent discoveries for which the program has not yet received first-hand information; others are old, obscure reports

SYN Synonym - Species reported as occurring in Montana, but the Montana Natural Heritage Program does not recognize the taxon; therefore the species is not assigned a rank

A rank has been assigned and is under review. Contact the Montana Natural Heritage Program for assigned rank

B Breeding - Rank refers to the breeding population of the species in Montana 